
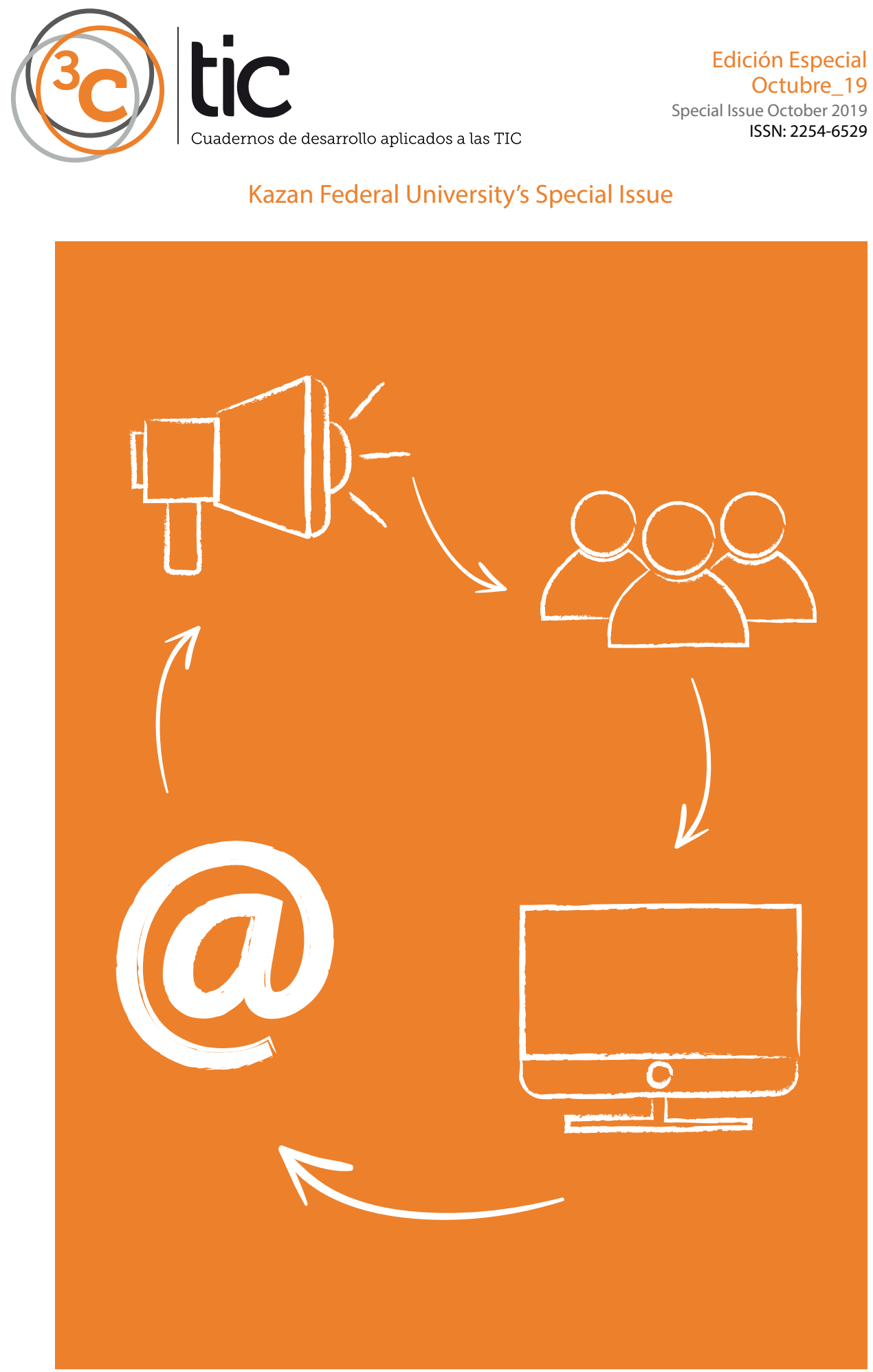
3G TIC. Guadernos de desarrollo aplicados a las TIC.

Periodicidad trimestral. Quarterly periodicity.

Edición Especial. Special Issue.

"Kazan Federal University's Special Issue"

Tirada nacional e internacional. National and internacional circulation.

Artículos revisados por el método de evaluación de pares de doble ciego.

Articles reviewed by the double blind peer evaluation method.

ISSN: $2254-6529$

No de Depósito Legal: A 268 - 2012

DOI: https://doi.org/10.17993/3ctic.2019.83-2

Edita:

Área de Innovación y Desarrollo, S.L.

C/ Els Alzamora 17, Alcoy, Alicante (España)

Tel: 965030572

info@3ciencias.com_www.3ciencias.com

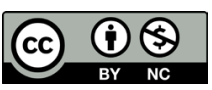

Todos los derechos reservados. Se autoriza la reproducción total o parcial de los artículos citando la fuente y el autor. This publication may be reproduced by mentioning the source and the authors. Copyright (C) Área de Innovación y Desarrollo, S.L. 


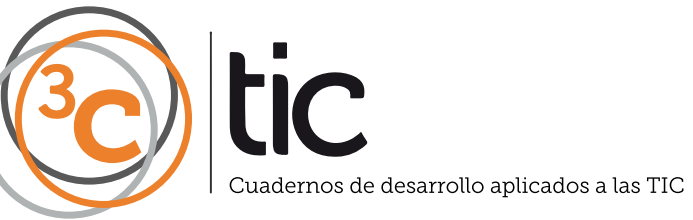




\section{CONSEJO EDITORIAL EDITORIAL BOARD}

Director

Director

Editores adjuntos

Assistant editors

Editores asociados

Associate editors
Víctor Gisbert Soler

María J. Vilaplana Aparicio

Maria Vela Garcia

David Juárez Varón

F. Javier Cárcel Carrasco

\section{CONSEJO DE REDACCIÓN DRAFTING BOARD}

Dr. David Juárez Varón. Universidad Politécnica de Valencia (España)

Dr. Martín León Santiesteban. Universidad Autónoma de Occidente (México)

Dr. F. Javier Cárcel Carrasco. Universidad Politécnica de Valencia (España)

Dr. Alberto Rodríguez Rodríguez. Universidad Estatal del Sur de Manabi (Ecuador)

\section{CONSEJO ASESOR ADVISORY BOARD}

Dra. Ana Isabel Pérez Molina. Universidad Politécnica de Valencia (España)

Dr. Julio C. Pino Tarragó. Universidad Estatal del Sur de Manabi (Ecuador)

Dr. Jorge Francisco Bernal Peralta. Universidad de Tarapacá (Chile)

Dr. Roberth O. Zambrano Santos. Instituto Tecnológico Superior de Portoviejo (Ecuador)

Dr. Sebastián Sánchez Castillo. Universidad de Valencia (España)

Dra. Sonia P. Ubillús Saltos. Instituto Tecnológico Superior de Portoviejo (Ecuador)

Dr. Jorge Alejandro Silva Rodríguez de San Miguel. Instituto Politécnico Nacional (México) 


\section{CONSEJO CIENTÍFICO TÉCNICO TECHNICAL SCIENTIFIC BOARD}

Área téxtil

Textile area

Área financiera

Financial area

Organización de empresas y RRHH

Organization of companies and $H R$

Estadística; Investigación operativa

Statistics; Operative investigation

Economía y empresariales

Economy and business

Sociología y Ciencias Políticas

Sociology and Political Science

Derecho

Law

Ingeniería y Tecnología

Engineering and Technology

Tecnologías de la Información y la

Comunicación

Technology of the information and communication

Ciencias de la salud

Health Sciences
Dr. Josep Valldeperas Morell

Universidad Politécnica de Cataluña (España)

Dr. Juan Ángel Lafuente Luengo

Universidad faime I (España)

Dr. Francisco Llopis Vañó

Universidad de Alicante (España)

Dra. Elena Pérez Bernabeu

Universidad Politécnica de Valencia (España)

Dr. José Joaquín García Gómez

Universidad de Almería (España)

Dr. Rodrigo Martínez Béjar

Universidad de Murcia (España)

Dra. María del Carmen Pastor Sempere

Universidad de Alicante (España)

Dr. David Juárez Varón

Universidad Politécnica de Valencia (España)

Dr. Manuel Llorca Alcón

Universidad Politécnica de Valencia (España)

Dra. Mar Arlandis Domingo

Hospital San Juan de Alicante (España) 


\section{OBJETIVO EDITORIAL}

La Editorial científica 3Ciencias pretende transmitir a la sociedad ideas y proyectos innovadores, plasmados, o bien en artículos originales sometidos a revisión por expertos, o bien en los libros publicados con la más alta calidad científica y técnica.

\section{NUESTRO PÚBLICO}

- Personal investigador.

- Doctorandos.

- Profesores de universidad.

- Oficinas de transferencia de resultados de investigación (OTRI).

- Empresas que desarrollan labor investigadora y quieran publicar alguno de sus estudios.

\section{COBERTURA TEMÁTICA}

3C TIC es una revista de carácter científico-social en la que se difunden trabajos originales que tratan sobre la aplicación de las Tecnologías de la Información y Comunicación (TIC) y las Telecomunicaciones a la Sociedad, la Educación y la Gestión Empresarial.

\section{INFORMACIÓN PARA AUTORES}

Toda la información sobre el envío de originales se puede encontrar en el siguiente enlace:

http://www.3ciencias.com/normas-de-publicacion/instrucciones-para-elenvio-de-articulos/ 


\section{PUBLISHING GOAL}

3Ciencias wants to transmit to society innovative projects and ideas. This goal is reached thought the publication of original articles which are subdue to peer review or thorough the publication of scientific books.

\section{OUR TARGET}

- Research staff.

- PhD students.

- Professors.

- Research Results Transfer Office.

- Companies that develop research and want to publish some of their works.

\section{TEMATIC COVERAGE}

3C TIC is a scientific-social journal that spreads original works related with the application of Information and Communication Technologies (ICT) and Telecommunications to Society, Education and Business Management.

\section{INSTRUCTIONS FOR AUTHORS}

All information about sending originals can be found at the following link: https://www.3ciencias.com/en/regulations/instructions/ 


\section{INDIZADO POR \\ INDEXED BY}

Plataforma de evaluación de revistas
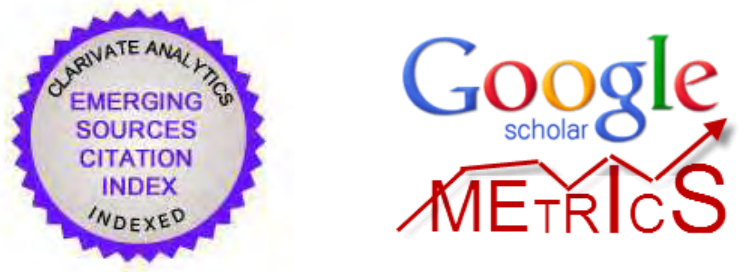

Bases de datos internacionales selectivas

\section{EBSCOhost}

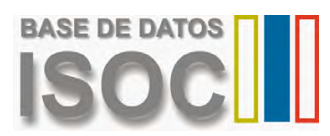

Business Source 배뵤 Premier

$\underset{\text {.net }}{\text { OAl }} \begin{aligned} & \text { Open Academic } \\ & \text { Journals Index }\end{aligned}$
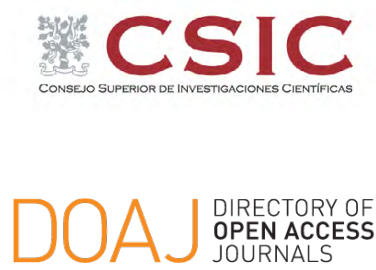

JOURNALS
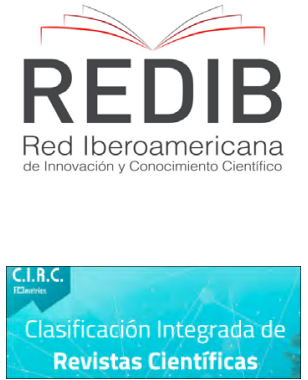

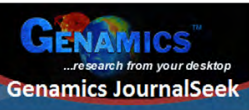


Directorios selectivos

\section{latindex}

Hemerotecas selectivas

\section{- Dialnet}

Buscadores de literatura científica en acceso abierto 


\section{/SUMMARY/}


Foreign students' adaptation to living and studying conditions in Tatarstan

Mentality as one of the most significant attributes of nation: historical and metodological aspects

Liliya Radikovna Sakaeva, Irina Germanovna Kondrateva, Marat Aidarovich Yahin \& Evgeniya Vladimirovna Kuznetsova

Non-refoulment and age assessment of minors

Kamila Danilovna Shaibakova \& Adel Ilsiyarovich Abdullin 44

Productive ways of formation of chemical and biological terms (in English, Russian and Tatar languages)

Leila Aivazovna Nurgalieva, Lucia Munirovna Ibatulina \&Venera Nafikovna Khisamova

The concept "student" in the Russian and German linguocultures

Dilyara Marsovna Sadykova, Tatiana Yakovlevna Zaglyadkina, Olga Valerevna Akimova, Alfiya Nailevna Zaripova

The techniques of teaching Business English to the students of linguistics major

Natalia Nikolaevna Bobyreva \& Karina Muratovna Amirkhanova

Reducing the problem of waveguide excitation by currents in crosssection to a system of integral volterra equations

The integration of pedagogical technologies as a condition for improving the quality of education

Elzara V. Gafiyatova, Dina Z. Gaynutdinova, Albina T. Galiakhmetova \& Viktoriya Levchenko

Formation of senior students' sociocultural competence by means of blog technology 
Improvement of students critical thinking through the using of the method of case studies

Project activity as a means of improving the quality of professional training of future philologists

Guzel A. Izmaylova, Leilya R. Mukhametzyanova, Natalia V. Konopleva \& Natalia V. Gorbunova

Formation of rhetorical skills in school: Mental features and active teaching methods

Anastasiia A. Korshunova, Elena M. Bastrikova, Sholpan K. Zharkynbekova, Kuralay B. Urazayeva \& Karlygash S. Abylkhassova

Rating control in learning to Russian as a foreign language

Anna Alexandrovna Erofeeva, Tatyana Alexandrovna Korneyeva \& Tatyana Damirovna Markova

Competence of graduates of higher professional education as an object of sociological reflection

Valentina Vladimirovna Fursova, Makpal Barkiyayevna Syzdykova, Talant Dyusenuli Bimakhanov \& Maria Alievna Makhambetova

An integrated approach to the organization of kindergartens territory

Olga Vladimirovna Bakurova \& Irina Anatolyevna Rysaeva

Features of value orientations of students of future teachers

Bakhtiyar Railevich Fakhrutdinov, Rezeda Kamilevna Khurmatullina, Nadezhda

Petrovna Yachina \& Flera Gabdulbarovna Mukhametzyanova

Tatar culture-specific words of the semantic field 'animals' relative to English

Mohtarovna Nurtdinova, G. y Marsovna Sadykova, D.

The fintech and islamic finance synthesis in the modern world

Elvira Ildarovna Bulatova, Ekaterina Alekseevna Potapova, Regina Andreevna

Fathutdinova \& Ruslan Chirgishanovich Yandiev 
Interdisciplinarity in studying Modern Russian poetry in school

Alina R. Gaynutdinova, Alfiya F. Galimullina, Artem E. Skvortsov \& Sergey A.

Zinin

Foreign experience in the individuals tax control

Salmina, S.V., Tufetulov, A.M., Nasyrova, V.I. \& Khafizova, A.R.

286

Rabotnitsa and bezdel'nitsa: russian femininitives with suffix -nitsa

Guzaerova, R.R., Sabolová, D. \& Kosova, V.A.

Movement of financial resources in affiliated SMES

Diana Shamilevna Usanova, Eugenia Urievna Strelnik, Elvira Ildarovna

Khairullina \& Elena Evgenievna Beloglazova

Tax debt and ways of reducing it

M.E. Orlova, V.I. Nasyrova \& S.V. Salmina

Tax exemptions for health care in Russia

M.E. Orlova, F.F. Adigamova, V.I. Nasyrova \& S.V. Salmina

346

Theoretical aspects of tourism attractiveness and its estimation by the example of the Republic of Tatarstan

Gulnara Faridovna Valeeva, Oleg Aleksandrovich Bunakov, Boris Moishevich

Eidelman \& Liliya Raisovna Fakhrutdinova 


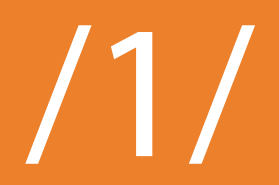




\section{FOREIGN STUDENTS' ADAPTATION TO LIVING AND STUDYING CONDITIONS IN TATARSTAN}

E.V. Salimullina

Kazan Federal University, Kazan, Russia.

M.S. Ilina

Kazan Federal University, Kazan, Russia.

I.A. Sherbakova

Kazan Federal University, Kazan, Russia.

E-mail: steelmar@yandex.ru

Recepción: 05/08/2019 Aceptación: 09/09/2019 Publicación: 23/10/2019

\section{Citación sugerida:}

Salimullina, E.V., Ilina, M.S. y Sherbakova, I.A. (2019). Foreign students' adaptation to living and studying conditions in Tatarstan. 3C TIC. Cuadernos de desarrollo aplicados a las TIC. Edición Especial, Octubre 2019, 14-29. doi: https://doi.org/10.17993/3ctic.2019.83-2.14-29

Suggested citation:

Salimullina, E.V., Ilina, M.S. \& Sherbakova, I.A. (2019). Foreign students' adaptation to living and studying conditions in Tatarstan. 3 C TIC. Cuadernos de desarrollo aplicados a las TIC. Special Issue, October 2019, 14-29. doi: https://doi.org/10.17993/3ctic.2019.83-2.14-29 


\section{ABSTRACT}

At present the problem of foreign students' adaptation is one of the most urgent issues in educational system. During cultural adaptation process two main factors are distinguished: the solution of different adaption students' problems and the dynamics of their motivation. It is based not only on the system of cultural aspects and their changes, but also on various issues of interpersonal relations. Motives are as one of the important aspects of cultural adaption system. Social and psychological changes of foreign students' motivational sphere depend on different cultural features, person's intentions and aims of living in a new country, their further profession and career development. Though there are some works on cultural interaction and relations between representatives of different cultures; in Tatarstan the problem of foreign students' adaptation to living and studying conditions still exist nowadays.

\section{KEYWORDS}

The Russian language, Culture, Intercultural communication, Linguistic and cultural competence, Adaptation, Foreign students. 


\section{INTRODUCTION}

Foreign language knowledge may be defined as a component of a person's general culture with the help of which he/she (a personality) joins the world culture (Ilina \& Voprosu, 2016). At present, the main and global aim to master a foreign language is as an interaction of different cultures and participation in "dialogue of cultures" (Ilina, Vildanova, \& Timirgaleeva, 2017). In our opinion, increasing social demand for learning a foreign language can be explained by present global processes happening in the world: the European market provides new aspects in the study of a foreign language (Ilina et al., 2017).

One of the most important tasks of a teacher is to create conditions for a successful educational and cognitive students' activity (Ilina \& Mullagajanova, 2016).

The purpose of our work is to study socio-psychological and personal problems of foreign students' adaptation to living and studying conditions in Tatarstan. It has scientific interest in theoretical and practical aspects. The problem of foreign students' adaptation has not been thoroughly investigated from psychological and pedagogical points of view. To our opinion adaptation is a complex process; the result of certain established relationships between a person and social environment. There are two coherent constituents: a man and his/her environment (Murzinova et al, 2018; Pinto-Rojas \& Parraguez, 2017; Kheirabadi \& Mirzaei, 2019).

This research is aimed at scientific and practical analyze of cultural interaction problems.

Gradually students' motivational system is changed. It influences on students' behavior patterns. The patterns of educational person's motives are examined. Several factors may influence on adaptation process of foreign students in Tatarstan. These factors are mutual interaction of people, intensity of interaction, cultural peculiarities, several foreign representatives, official University policy, etc. In practice, various types of relationships are established. Some groups of foreign students are completely losing their cultural uniqueness and identity, others, on the contrary, keep their cultural peculiarities and sometimes have some influence 
on Russian students. Finally this interaction always leads to cultural changes in adaption system. Indeed, culture is an integrative person's quality, adequately regulating its socio-cultural and professional status. It determines student's ability in educational and professional spheres including special information and a foreign language learning (Ilina \& Kostyunina, 2016; Kashisaz \& Mobarak, 2018).

The problem of a research consists in defining different conditions of successful foreign students' adaptation to new living and studying conditions in Tatarstan.

The purpose of the research is significant feature identification of foreign students' motivational dynamics during studies in foreign culture conditions in Tatarstan.

The research object is motivation identification of foreign students' educational activities in Tatarstan.

The object of the research is significant features identification of foreign students' motivational dynamics in different socio-cultural conditions in Tatarstan.

The research hypothesis is intentions to develop professional career in a country of study influence on foreign students' motivational dynamics during studies in foreign organizational culture in Tatarstan.

Foreign students, planning to continue their professional career in the country of study, are more prone to motivation changes during studies in Tatarstan.

The purpose and hypothesis of the research have defined the solution of the following tasks:

1. Development of theoretical and methodological approaches to social and psychological adaptation analysis;

2. Theoretical investigation of motivational dynamics during studies in Kazan State University, in Tatarstan;

3. Development of conceptual research and methodological scheme of foreign students' successful adaptation in Tatarstan; 
4. Adaptability research of different foreign students' age groups;

5. An empirical study of foreign students' motivational dynamics during studies in different social and cultural conditions.

The methodological basis of a research includes philosophical concept of general communication; phenomena and activity inter-conditionality as the way of a person's self-realization in work and communication; philosophic and humanistic approaches; theory and practice interrelation; culture comprehension of philosophical category.

The system, personal activity and culturological approaches are used as a special methodology.

Theoretical significance reveals a complex of pedagogical conditions, directed in successful realization of foreign students' adaptation to living and studying conditions in Tatarstan:

1. Original techniques of foreign students' motivational dynamics research are worked out;

2. Comparative analysis of foreign students' motives from Estonia, Turkmenistan, Tajikistan, Uzbekistan, Armenia, Kyrgyzstan, Kazakhstan is carried out;

3. Essential features of foreign students' motivational dynamics during studies in Kazan Federal University are revealed

\section{Practical significance}

Got results can be used in higher educational Institutions. The change of motivational dynamics is one of the central aspects of successful foreign students' adaptation in new socio-cultural conditions in Tatarstan. In this regard, it is important to understand and control foreign students' motivational changes of foreign students. 


\section{METHODS}

To achieve this goal, we studied the adaptation of a foreign student in the social and educational realities of the university in the process of professional training in the sociocultural field (NCHI) of the KFU, in Tatarstan. The subject of the study was foreign students who undergo a full cycle of training at KFU. The sample type is quota based on the nationality and citizenship of respondents (Estonia, Turkmenistan, Tajikistan, Uzbekistan, Armenia, Kyrgyzstan, Kazakhstan), and by age (18-25 years). The sample size is 72 people.

To collect the diagnostic material, we conducted a natural experiment, used a survey method. During the interview we talked with the students, discussed the socio-psychological portraits of ethnic groups. It was necessary, since several students had difficulties in understanding the Russian language, and during the conversation we overcame the language barrier that prevents the receipt of representative data. Using the method of included observation, we made an assessment concerning the correspondence of portrait characteristics of ethnoses among the participants in the experiment. At the next stage we studied the motivational readiness for a new social and educational environment, vocational training, overcoming the language barrier and language training. This work was carried out on a specially developed questionnaire containing closed and semiclosed questions.

\subsection{IN CONCLUSION THE MAIN RESULTS OF THE WORK ARE MADE}

After direct communication with students, we note that not all of them have a desire to study or improve their knowledge of the Russian language, use it in communication, the following statements prove this fact: "there is no desire to learn the language," "I answer when the teacher asks me", "I did not intend to come to Russia, my parents forced me," "I will not come to Russia anymore," "I do not like complicated language," "I sometimes use cheat sheets, write down assignments," "I only want to get a diploma "( $18 \%$ of students), the motivational 
readiness to master the language environment and the language itself is not formed in $15 \%$ of students, but practically all young students in informal communication use profanity of the Russian language.

In the process of learning, foreign students build their own strategy of behavior differently. Some are more passive, they want more attention. In the process of adaptation, individual characteristics are inherent in the national character patience, the ability to endure life's difficulties, enterprise, striving for the goal. However, due to the peculiarities of division into "one's own" and "others", the value hierarchy of a sense of national pride, superiority complicates entry into the foreign culture environment. This predisposes rather to accommodation or pseudo-adaptation. Some are more independent, efficient, cautious, persevering; they are characterized by cognitive practicality, conscientiousness, punctuality, accuracy, diligence, technical mentality.

Adaptation of foreign students to new conditions depends on the attitude of the host party, mutual sympathy, antipathy, stereotypes (Ilina \& Voprosu, 2016), socio-cultural and psychological characteristics of different ethnic groups, the knowledge of them helps university staff understands and explain the readiness of foreign students to adapt to another socio-cultural and educational environment. The use of cheat sheets and cheating influences the process of adaptation of foreign citizens negatively. Such a behavior makes the adaptation process difficult, but at the same time, as our study showed, $21 \%$ of foreign students are ready to use such methods by the end of training (Nakhaee \& Nasrabadi, 2019).

Thus, the adaptation of foreign students in a new country is associated with psycho-physiological, educational and cognitive difficulties; inadequate language training, overcoming differences in education systems; with new requirements and a system of knowledge control; with the difficulties of mastering the new socio-cultural and educational space of the university; moral and ethical norms of behavior and coexistence, difficulties in everyday life (Dehdar et al., 2019; Eslami \& Ahmadi, 2019; Jabbari et al., 2019). 
The results of revealing the parameters of the students' motivational readiness showed that for the students of the KFU, like the results of the research published in the literature (Aydarova et al., 2017). the factors of satisfaction with life and study are as follows: positive attitudes with people around them; the desire of teachers to teach, to transfer knowledge by profession, the use of information technology; safety of life in the city. Education is perceived as an opportunity for socio-cultural and professional mobility.

Adaptation of foreign students to a new socio-cultural, linguistic and educational environment begins with entry into the cultural and educational environment. The main meaningful goal in the new environment for each student is the creation of subjectively significant comfortable living conditions and peace of mind, so during the initial adaptation they do not try to understand and become part of a culture and the system of life unfamiliar to them. Organization of the process of interaction is more freely aligned with students of its ethnos, thereby becoming more desirable and there is no need for communication with Russian students. The staff controlling the process of professional training of foreign students at the university should pay special attention to the formation of their motivation and necessity to show their activity, interest and desire to deepen and expand the information field of culture and life features of citizens of Tatarstan.

\subsection{THE EXPERIMENTAL BASE OF THE RESEARCH}

Experimental work was carried out in Kazan State University, in Tatarstan.

\subsection{THE STAGES OF THE RESEARCH}

The research was carried out in several stages.

The first phase of the research was dedicated to the study and analysis of domestic and foreign psychology-pedagogical literature on the research problem; understanding methodological and theoretical foundations of the research; 
determining the nature, structure and content of the notion "adaptation", formation of experimental and control groups; planning of the teaching experiment. At this stage we had an experiment in Kazan State University.

At the second stage, necessary conditions for a successful foreign students' adaptation were singled out to living and studying conditions in Kazan State University, in Tatarstan. This stage included analysis, processing, generalization and systematization of experimental work results; formulation of conclusions and development of methodological recommendations on the investigated problem, their introduction into the practice of educational institutions, formulation of thesis.

\section{RESULTS AND DISCUSSION}

\subsection{DURING THE RESEARCH, THE TASKS WERE SOLVED, AND THE MAIN HYPOTHESES WERE CONFIRMED}

A review of the work of domestic and foreign researchers on the problem of adaptation of foreign students in the conditions of a new socio-cultural environment showed that the situation is indicated correctly, and the topic of research is relevant.

1) Adaptation is a process, the course of which depends on individual traits and skills, the characteristics of the situation, the strength of the changes required by the individual, the time spent in the new culture, previous experience and training, and close social ties with the representatives of the country in which they are located.

2) The solution of the problem of motivation of educational activity is determined by the fact that the motivation of the teaching is necessary for the effective implementation of the educational process. 
3) Intentions concerning the development of a professional career in the country of instruction influences the dynamics of the motives of educational activity of foreign students studying in conditions of a foreign organizational culture of the university.

4) Foreign students planning to continue their professional career in the country of study are more likely to change their motivational environment.

5) It also became clear that a two-year period of stay in conditions of interaction with the holders of the dominant socio-cultural environment of the university is enough for a significant change in the motives of educational activity.

\subsection{STAGES}

\subsubsection{ASCERTAINING STAGE}

At the first stage, the main approaches to the study of psychological adaptation are considered. The section provides an overview of various features of sociopsychological adaptation in the framework of various socio-psychological and psychological paradigms. Social psychologists define adaptation as interaction and mutual influence of the individual and the social environment, living in a system of intragroup relations and the development of standards of communication, behavior that reflect the system of values and norms of the production team with the active influence of past social experience, psychological qualities and personality characteristics. Also in the section the main factors affecting the process of adaptation of foreign students to a new socio-cultural environment were considered.

\subsubsection{FORMING STAGE}

During the forming stage of the experiment scientific and methodological adaptation research was developed and implemented. It included software, training manuals, guidelines and a diagnose Tatarstan tic Tools. 


\subsection{THE CONDITIONS OF SUCCESSFUL FOREIGN STUDENTS' ADAPTATION PROCESS TO LIVING AND STUDYING CONDITIONS IN TATARSTAN}

The features of successful foreign students' adaptation process to living and studying conditions in Tatarstan shown in the determinism of content selection of educational information, forms, methods of teaching, goals of teaching a foreign language and explanation.

\subsection{EXPERIMENTAL VERIFICATION OF THE EFFECTIVENESS OF THE PROPOSED CONTENT OF SUCCESSFUL FOREIGN STUDENTS' ADAPTATION PROCESS TO LIVING AND STUDYING CONDITIONS IN TATARSTAN}

Stated results showing the differences during the process of foreign students' adaptation in control and experimental groups are statistically significant. Consequently, the revealed and theoretically grounded pedagogical issues of effective influence on the succession process of communicative culture's formation. Comparative analysis of the issues at different levels of the research allows us how to conclude that at the first stage, along with the motivational factor is determined. It helps to mastery communicative skills and a higher degree of complexity (cross-cultural, professionally directed, and specialized) at the stage of University education in Tatarstan.

The experiment proves the use of authentic situations-the problematic nature affected by the efficiency of the educational process at each stage of learning a foreign language. The participants of the communication were able to communicate.

The analysis of scientific works devoted to the problem of foreign students' adaptation to living and studying conditions in Kazan State University, in Tatarstan. 


\section{CONCLUSIONS}

The decision to create optimal conditions for the adaptation of foreign students is almost entirely is a function of the university. Experience shows that an effective mechanism for managing the process of socio-cultural, educational and professional adaptation of foreign students is the system of coordinated and responsible interaction of all structural units of the university. Among the conditions is a system of joint actions of students, considering their established values, the foundations of the cultural stock of their ethnos, the development of readiness to be active participants of the educational process, etc.

For example, the KFU successfully implements the existing system of work that ensures the adaptation of foreign students. Its essence lies in the creation of optimal conditions for fast and safe adaptation of foreign students in the field of professional training of a foreign specialist. It correlates with the socio-pedagogical support for the adaptation of foreign students, affecting the success of training and psychological development in situations of interaction conditioned by the status of a foreign student in a new environment for themselves. In addition, the system work is aimed at solving natural difficulties for the first year student to meet the requirements of the university, manage their needs and desires due to the age and status of their ethnic group.

It will be natural that the success of the process of adaptation of foreign students will proceed with the appropriate socio-pedagogical conditions, considering the coinciding socio-cultural values of both sides, the student and the country of the host institution. Teachers participating in the course of mastering a future profession by a foreign student are previously acquainted with cultural and ethnic characteristics, value orientations, readiness to learn, and adaptive abilities of students.

Active attraction of foreign students to out-of-class activities, creation of educational and living conditions promotes adaptation of the target audience. 
Currently, the university is working towards the creation of a modern educational and methodological support for the teaching and educational process, Englishlanguage programs, methodological equipment for individual courses, the formation of students' motivation and interest in mastering the language.

Our research has shown that the peculiarities of adaptation of foreign students are determined by a complex of factors and are conditioned by the formation of readiness to include an individual in a new social and educational space. The effectiveness of adaptation allows us to assess the multilateral process of equal interaction of foreign students with the cultural, educational and intellectual environment of the host institution adequately, maintain psycho-emotional balance, form the necessary personal and professional qualities, master the Russian language, new roles that support the social status, and realize the importance of their profession.

\section{ACKNOWLEDGEMENTS}

The work is performed according to the Russian Government Program of Competitive Growth of Kazan Federal University.

\section{REFERENCES}

Aydarova, A. M., Vildanova, E. M., \& Ilina, M. S. (2017). The social and pedagogical qualities of modern vocational training teachers. Modern fournal of Language Teaching Methods, 7(9), 102.

Dehdar, M., Sayegani, L., Arbab, E., Arzhandeh, M., Roshanray, M., Raeisi, A., \& Kuhi, L. (2019). Role of schools in educating the active citizen. UCT Journal of Social Sciences and Humanities Research, 7(1), 13-18. 
Eslami, R., \& Ahmadi, S. (2019). Investigating the Role of Educational Media on Secondary School Students' Learning Process Improvement in Jahrom City. Fournal of Humanities Insights, 3(01), 13-6. doi: https:/ / doi.org/10.22034/ jhi.2019.80890

Ilina, M. S., \& Kostyunina, N. Y. (2016). Continuity of communicative culture creating in teaching process of foreign languages (school-technical school-university). International Electronic Fournal of Mathematics Education, 11(6), 1867-1878. Retrieved from https://www.iejme.com/article/continuity-ofcommunicative-culture-creating-in-teaching-process-of-foreign-languages

Ilina, M. S., \& Mullagajanova, G. S. (2016). Znachenie situativnogo podhoda $\mathrm{v}$ processe obucheniya inostrannomu yazyku [The value of the situational approach in the process of learning a foreign language] Global'nyj nauchnyj potencial - Saint-Petersburg, 9(66), 7-10.

Ilina, M. S., \& Voprosu, K. (2016). o nravstvenno-duhovnyh osobennostyah lichnosti [On the issue of moral and spiritual features of personality] Social'noehkonomicheskie i tekhnicheskie sistemy: issledovanie, proektirovanie, optimizaciya: ehlektronnyj zhurnal: Materialy II--oj mezhdunarodnoj nauchno-prakticheskoj konferencii «Duhovno-gravstvennoe razvitie molodezhi: mezhdisciplinarnaya problema XXI veka» (13-14 oktyabrya 2016 g. g.Naberezhnye Chelny) - Naberezhnochelninskij institut Kazanskogo Federal'nogo Universiteta, 5(72), 117-122.

Ilina, M. S., Vildanova, E. M. \& Timirgaleeva, A. R. (2017). Osobennosti sovremennogo zanyatiya inostrannogo yazyka v vysshem uchebnom zavedenii [Features of modern foreign language classes in higher educational institution] Global'nyj nauchnyj potencial - Saint-Petersburg, 9(78), 11-13. 
Ilina,M.S., Vildanova,E.M., \&Mullagajanova,G.S.(2017). Preemstvennost' formirovaniya kommunikativnoj kul'tury v processe obucheniya inostrannomu yazyku [Continuity of formation of communicative culture in the process of learning a foreign language] Perspektivy nauk - Saint-Petersburg, 1(88), 116118.

Jabbari, E., Charbaghi, Z., \& Dana A. (2019). Investigating the Effects of Educational and Motivational Education at Different Levels on the Performance and Application of dart throwing. Fournal of Humanities Insights, 3(02), 37-44. doi: https://doi.org/10.22034/jhi.2019.80896

Kashisaz, S., \& Mobarak, E. (2018). The Effects of Private Education Institutes in Providing Modern Financial Knowledge in Developing Countries. Fournal of Humanities Insights, 02(04), 172-8. doi: https://doi.org/10.22034/ jhi.2018.80887

Kheirabadi, M. A., \& Mirzaei, Z. (2019). Descriptive valuation pattern in education and training system: a mixed study. Fournal of Humanities Insights, 3(01), 7-12. doi: https://doi.org/10.22034/jhi.2019.80889

Murzinova, K. E. A., Koblanova, A., \& Ansabayeva, D. A. A. (2018). Prosodical means applied in communicative relations. Opción, 34(85-2), 61-96.

Nakhaee, J., \& Nasrabadi, M. A. (2019). Strategies for Research-Centered Education of Architectural Designing by Examining the Research-Centered Activities of the Top Universities. Fournal of Humanities Insights, 3(02), 50-6. doi: https://doi.org/10.22034/jhi.2019.80898

Pinto-Rojas, I. E., \& Parraguez, M. (2017). Articulators for Thinking Modes of the Derivative from a Local Perspective. International Electronic Fournal of Mathematics Education, 12(3), 873-898. Retrieved from https://www.iejme. $\mathrm{com} /$ article/articulators-for-thinking-modes-of-the-derivative-from-a-localperspective 
/2/ 


\section{MENTALITY AS ONE OF THE MOST SIGNIFICANT ATTRIBUTES OF NATION: HISTORICAL AND METODOLOGICAL ASPECTS}

Liliya Radikovna Sakaeva

Kazan Federal University, Institute of International Relations.

Irina Germanovna Kondrateva Kazan Federal University, Institute of International Relations.

Marat Aidarovich Yahin Kazan Federal University, Institute of International Relations.

Evgeniya Vladimirovna Kuznetsova University of Management "TISBI"

E-mail: liliyasakaeva@rambler.ru

Recepción: 05/08/2019 Aceptación: 09/09/2019 Publicación: 23/10/2019

Gitación sugerida:

Sakaeva, L.R., Kondrateva, I.G., Yahin, M.A. y Kuznetsova, E.V. (2019). Mentality as one of the most significant attributes of nation: historical and metodological aspects. $3 C$ TIC. Cuadernos de desarrollo aplicados a las TIC. Edición Especial, Octubre 2019, 30-43. doi: https://doi.org/10.17993/3ctic.2019.83-2.30-43

Suggested citation:

Sakaeva, L.R., Kondrateva, I.G., Yahin, M.A. \& Kuznetsova, E.V. (2019). Mentality as one of the most significant attributes of nation: historical and metodological aspects. 3C TIC. Cuadernos de desarrollo aplicados a las TIC. Special Issue, October 2019, 30-43. doi: https://doi.org/10.17993/3ctic.2019.83-2.30-43 


\section{ABSTRACT}

The authors prove their thinking as the most important issue for any nation in their writing. Scholars have not reached any agreement on the nature of matter, nature, and personality. It deals with these issues. Every person in a community has a part of a place in the community (a class, a church community, an ethnicity, a state, etc.). That comes from a friend or foe that shows an ancient dichotomy. In a national entity, there is always a prevailing stable thing We call it mentality. A popular individuality cannot be qualified by sole property but by social trait, why. And today, in the visage of a date of the procedure of globalization integration, it is significant to citation this reality.

\section{KEYWORDS}

Language, Mentality, Nations, Tatar, Greek, Character, Community, Culture, Archetype, Globalization. 


\section{INTRODUCTION}

Ethnocultural and ethnonational revival of self-consciousness of population in the secondary mid of the 20th centenary is one of the main features of the development of mankind at the present stage. This is due to the subject's desire to identify himself as a part of a social community adequately to form his identity in modern conditions complicated by processes of globalization and integration. Any social community, whether ethnic, cultural, religious or linguistic has a complicated structure and complex content defined by the history of its development and interaction. The nature of one or another social community depends on the nature of the identity of its agents (Kalegina et al., 2015; Kashisaz \& Mobarak, 2018). Social communities change from time to time, their earliest type is tribes. Tribes originally consisted of several social "cells" connected with blood ties. Nowadays the term "tribe" represents ethnic groups on different levels of social, economic and cultural development. Some of these tribes are small (include hundreds of people), others are more numerous (number thousands, tens of thousands). Now only nomadic and semi-nomadic peoples have features of tribal organization. Gradually, the communal operation decayed, tribes united in unions, such as the League of the Iroquois in North America or Tatar-Mongols in Eurasia, they replaced blood links and formed a new type of ethno-social community - peoples (Baykalova et al, 2018; Kheirabadi \& Mirzaei, 2019).

The first peoples were formed in the slave era. There were ancient Egyptians, ancient Greeks and Romans. Later drevlyane, krivichi, vyatichi formed ancient Russian people. As ethnic processes taking place during the whole period of existence of humanity, are quite complicated and varied, there is nothing surprising in the fact that many scientists appeal to their investigation. With the beginning of the formation of states a new type of ethno-social collectivity nation - begins to form itself. Nation as a product of era of modern times has become a completely new form of social community. Understanding of nation in different countries has been always different. In France, nation is a state, part of the civilization and it's distributed by urban bourgeois values. In Germany, nation is a community united by language and culture. In England the notion of nation 
relates to the notion of "Anglican Church". In the 16th century, the national consciousness had bright religious overtones when the Pope seemed to be the enemy of the nation. Another feature of the national consciousness of Britons is imperialism, formed due to the large number of British colonies. We can agree here that era of worldwide victory of capitalism over feudalism was associated with national movements. The formation of national states is the tendency of any national movement.

\section{METHODS}

As the history of nations is complex and controversial, the concepts of nation, ethnos, mentality are also complex and controversial, and the processes of globalization and integration make the problem of national identity serve as a key in defining of identity. Today, most oppositions in the reality of our people's social lives turn into a lack of awareness of social history, a misunderstanding of their conscious and subconscious ways that is usually hidden in the ethnic mindset of society. The difference between one nation and another lies in their thinking. This characteristic is understood from the generality of personality traits and behavioral traits. Philosophical research in society reveals many ways to teach and differentiate between clear principles and analysis, which in our view is the goal of philosophy in the unified theoretical analysis of the nature of thinking. We have said before that there is no difference knowledge and the nature of national personality from the point of view of scientists, but through various studies we address the problem of national personality and the cultural and historical significance of subjectivity. Due to the different approaches in the historical process we use the following historical and systematic comparative method. At the same time, the systematic approach helps to analyze the problem from different perspectives. 


\section{RESULTS AND DISCUSSION}

We must believe that the inner properties of different nations are not the same, and simply because of the old dichotomy (enemy, friend) this happens in different nations and people. Even in those primeval times, there were many descriptions of the way of life, personality traits and moral values of different nations. In ancient times, however, knowledge of the individual traits of each nation was studied in a descriptive, stored fashion, with only a practical focus, but has changed over time. At that time, the sciences were growing rapidly, leading to a comparative study of nations (history, geography, anthropology and linguistics), a profound and complete inference of acquired ethnological information. A modern theoretical model emerges that focuses on learning the facts about human behavior, but there are numerous variations in the activity of the masses of nations: for the first time they have made decisions about the historical destiny of their lands. In addition, the process of the creation of the European nations was accelerated. Since then, all these issues have prompted differences of opinion between different ethnicities to shift the issue of unpleasant interest and scientific analysis to many scholars. In the course of the twentieth century, educational questions about the character of a nation, its subjectivity, and the form of their historic substantiation are transforming into a research linking a national mind set and nature. Gimilf thinks that a national plural character is no more than a legend.

According to Gimilf in Year 5, while preserving the ethnological phase sequence for each new era, the personality traits of each nation always change according to a real situation, so a national character should not be regarded as a sustainable and liberal learning. A Gimblef illustrator cites the moving forces of a Russian national popular character, traits that have been traced back to different historical periods. In his work, Trofimov calls this methodological relativism. It shows Russian idea, roots, nature, and social cultural revelations, so the explanation of the national character means a period of historical sways, but the durability of some traits is declined. Some prevailing exegesis of the complexity of national character and subjectivity in modern scientific literature lead to the form of research studies. 
The new scientific literature of the national personality is described as follows:

A. Psychological attribute that exists in all peoples of one nation that makes the difference between each person and another.

B. Pack of psychological characters that most people in that country have.

C. A kind of character which is indicates arbitrary, classical for the people.

D. Generic traits of conducts and mentality, which typescripts diverge from a countrywide art.

E. A preferable method of intelligent, which is articulated in structures of a countrywide character.

F. A set of values, standards, inducement which regulates the lifestyle of states.

Such explanations imitate two kinds of organizational sets in defiance of a state personality, which are ethno psychological and ethno cultural. Both of types are subjected to a realistic reproach for its narrow-mindedness. From the point of ethno-psychologists a countrywide character is a historically industrialized set of constant psychological behaviors of executives for other ethnic clusters, which regulates their usual routine in attitude to a social medium, external things and to its and other ethnic communities. A national character is described by the totality of the characteristics and traits of a community whose only character is in its culture. In the works of the largest American sociology of Russian character, to understand a national character, the ethnic psychological approach has been heavily criticized. Sorokin paid attention to the secondary choice of individual and unique characteristics. they are not undistinguishable to characteristic landscapes of a prepared group and vice versa (Sorokin, 2010; Hasbullah \& Wibawa, 2017; Eslami \& Ahmadi, 2019).

Sorokin (2010) thought that attitude to a personality and nation is an individual case of a single and general dialectic, individual and origin. Certainly, a person has traits, which characterize the nation overall. Of a great number of individuals have specific national character traits. 
Fromm (1989) tried to understand a dynamic nature of a national character, its relationship with characteristics of a socio-cultural existence in his works. $\mathrm{He}$ explained many changes in a social transformation through discovery of a social potential of a national character. Particularly, he used the concept of a national character in a process of understanding the reasons of Nazism coming to a power in Germany. From his point of view, for German nation is inherent such qualities as love to a strong and hatred to a weak, limitation, stinginess in feelings and moneys. These qualities have formed that «social and human foundations», which became a favorable condition to an increase position of Nazism. But national character cannot be only reduced to the ways of behavior; it's a complex, common mechanism of a nation adaptation to one or another natural, social condition of its existence.

Many scientists point out that a national character is a "set of some traits of a spiritual character of a nation, which appears in its own traditional forms of a behavior and the perception of the environment" (Bloom, 1993). In the interpretation of Boas (1930), a national character is a common and personal elements and structures of any cultural traditions, which provide common or (its dominant) forms of a worldview, behavior and mentality. A national character is the most complex socio-cultural phenomenon, which is developed in different kinds of cultural activities. But for the last ten years, the term a "national character "is substituted for "mentality" (Boas, 1930). Representatives of a historical school in France have made a significant contribution to the research of mentality category. Jacques Le Goff distinguishes two kinds of reality as a material reality and the idea of this reality (mentality). Mentality is an independent and very important part of a historical process, but it is interpreted ambiguously: as a group view and manners; as modes of thought and sensation; as ethical codes and symbols.

For Gurevich (1999) mentality is a "live, changeable and for all that a detecting stable constants of life directions and manners, which depends on deep zones, inherent in that community and cultural traditions". Mentality reflects and realizes the picture of the nation's world, inherited from the previous generation 
and its life aspects which underlie them. The variety of mentality is a national mentality, original, modern equivalent of the term "soul of nation". In social philosophy there is a term «national mentality», as well as the terms "soul of nation", "national spirit", they are synonymic and used for description of cognate to its own inner world of spiritual and social aspects of ethnos and nations' life.

\section{SUMMARY}

The analysis that we have made, let us draw a conclusion that the concept of mentality is close to its meaning as an archetype and ideology. By comparing mentality and archetype, it should be pointed out what have in common is that they represent a group idea of people, an unconscious level of conscience. But archetypes, inherited by people from their ancestors are all same of individuals and social groups. Mentality is more dynamic and has a differentiated character. Like ideology, mentality relates to the interests of special social groups and has an influence on conceptualization of events of a political, economic and sociocultural character. But if in ideology, the social community realizes its interests and can formulate them as a theoretical contraction, but mentality is an unconscious level of a spiritual life and cannot be entirely expressed in rationally theoretical forms.

Different determinants can be pointed out during interpretation. Naturocentrism orientations appear in exaggeration of natural climatic causes in the formation of a mentality. For example, the theory of C. Montesquieu can be related to it; who is a representative of the geographical determinism about a decisive climate influence on people's character or O. Bauer's views on an inherited mechanism of essence of a nation. Theocentrism is in an acceptance of a dominant role of a religion. Chaadaev (2014) explains some traits, which are inherent in Russian nation as a (submission, incapacity to persistence, indifference to kindness and evil, truth and lie) by the influence of Orthodoxy. Sociocentrism overemphasizes socioeconomic determinants in formation of the mentality. There is a methodological basis of this approach in Marxism. As regard this, Engels (1955) writes that English 
workers and bourgeoisie was completely different people. Anthropocentrism notes that there is a meaning of upbringing in the understanding of a mentality. E. Erikson calls Russian soul as «a twisted soul». He notices that in Russia a tight child diapering relates to an unconscious need to convey the feeling of "a tight hand" (Erikson, 2009).

\section{CONCLUSIONS}

Man as a person always develops under a powerful influence of many social groups, in which he is a part of it and who takes part in achievement of his "inner self". Sigmund Freud pointed out several times, that every person is a component part of some social community. He and some other scientists noted that every person is a part of a class, church's community, ethnos, state, etc. (Freuds, 2011). In the process of socialization, a person forms socio-cultural (including ethnonational) norms, importance and values, as a result of it he gains a national identity, allowing him to consider as a bearer of a certain national mentality. Mentality is a dominant constant of a national existence, and today, against a background of globalization integration processes, it's important to define correctly mental traits each of nations and determine the reasons, that have caused specific traits to avoid possible cross-cultural conflicts. We should remember that the mentality of each nation is a unique and there are no good and bad nations. According to conditions, the same mental nature can be strong, weak and weak points of ethnos conscience. A modern socio-cultural situation makes its demands to learn the mentality issues, and today it's very important how a mental trait or set of traits can define behavior of people and have an influence on acts its separate representatives, what is role of the mentality of an ethno- national community in its today's interaction with other ethno- national communities.

\section{ACKNOWLEDGEMENTS}

The work is performed according to the Russian Government Program of Competitive Growth of Kazan Federal University. 


\section{REFERENCES}

Baykalova, E. D., Artyna, M. K., Dorzhu, N. S., Ochur, T. K., \& Mongush, D. S. (2018). Morphological interference in the process of mastering English speech in conditions of interaction of Tuvan, Russian and English as a foreign language. Opción, 34(85-2), 35-60.

Bloom, W. (1993). Personal identity, national identity and international relations (Vol. 9). Cambridge University Press.

Boas, F. (1930). Some problems of methodology in the social sciences. The new social science, 84-98.

Ghaadaev, P. Y. (2014). Stat'I I pis'ma, Moscow: Izd. "Modern Man”, 280s.

Engels, F. (1955). Polozhenie rabochego klassa v Anglii [Condition of the Working Class in England]. Marx, K. E̊ Engels, F. Sochineniya.

Erikson, E. (2009). Detstvo I obschestvo, SPb.: Izd "Lenato", "AST", "University Book", 540s.

Eslami, R., \& Ahmadi, S. (2019). Investigating the Role of Educational Media on Secondary School Students' Learning Process Improvement in Jahrom City. Fournal of Humanities Insights, 3(01), 13-6. doi: https:/ / doi.org/10.22034/ jhi.2019.80890

Freuds, S. (2011). Uber der Traum, Munchen, 411 p.

Fromm, E. (1989). A man for himself, Cambridge University Press, 288p.

Gumilev, L. N. (2010). Ot Rusi k Rossii, Moscow, Izd. "D-Dick", 542s.

Gurevich, A. Y. (1999). Mental'nost', Moscow: Izd. "Progress", 464s. 
Hasbullah, \& Wibawa, B. (2017). Analysis of Mathematics Students Ability in Learning Metacognitive Strategy Type Ideal (Identify, Define, Explore, Act, Look). International Electronic Fournal of Mathematics Education, 12(3), 859-872. Retrieved from https://www.iejme.com/article/analysis-of-mathematicsstudents-ability-in-learning-metacognitive-strategy-type-ideal-identify

Jabbari, E., Charbaghi, Z., \& Dana A. (2019). Investigating the Effects of Educational and Motivational Education at Different Levels on the Performance and Application of dart throwing. Fournal of Humanities Insights, 3(02), 37-44. doi: https://doi.org/10.22034/jhi.2019.80896

Kalegina, T. E., Takhtarova, S. S., \& Zaglyadkina, T. Y. (2015) Denglish and Franglais in the framework of the modern European linguistic landscape. Fournal of Language and Literature, 6(3), 195-198. Retrieved from http://dspace.kpfu.ru/xmlui/bitstream/handle/ net/142405/SCOPUS 20780303 -2015-6-3-SID 84959051476 -a 1. pdf;jsessionid=E97E1A2175E20B5E97CF759667A96BFB?sequence=-1

Kashisaz, S., \& Mobaraki, E. (2018). The Effects of Private Education Institutes in Providing Modern Financial Knowledge in Developing Countries. Fournal of Humanities Insights, 02(04), 172-8. doi: https://doi.org/10.22034/ jhi.2018.80887

Kheirabadi, M. A., \& Mirzaei, Z. (2019). Descriptive valuation pattern in education and training system: a mixed study. Fournal of Humanities Insights, 3(01), 7-12. doi: https://doi.org/10.22034/jhi.2019.80889

Nakhaee, J., \& Nasrabadi, M. A. (2019). Strategies for Research-Centered Education of Architectural Designing by Examining the ResearchCentered Activities of the Top Universities. Fournal of Humanities Insights, 3(02), 50-6. Retrieved from: http://www.jhumanities.net/article_80898_ dcaa625489b5f0ff63aea1583a374ee8.pdf 
Sakaeva, L. R., Sabirova, D. R., \& Kuznetsova, E. V. (2018). Culture and civilization: functional and methodological aspects. Revista Publicando, $5(16$ (1)), 435-442. Retrieved from https://revistapublicando.org/revista/index.php/ crv/article/view/1514

Solnyshkina, M. I., \& Ismagilova, A. R. (2015). Linguistic landscape westernization and glocalization: The case of Kazan, Republic of Tatarstan. XLinguae, 8(2), 36-53. doi: https://doi.org/10.18355/XL.2015.08.02.36-53

Sorokin, P. A. (2010). Glavnye kharakternye cherty pusskogo naroda v XX veke, Moscow: Izd. «Nauka» pp: 563s.

Tavana, M., Chamaneh, R., \& Chahe, T. (2019). The relationship between personality and mental health of employees Healthcare network in Sabzevar city. UCT Journal of Social Sciences and Humanities Research, 7(1), 8-12.

Travers, A. (1995). The Self Identification. Oxford, 340p.

Trofimov, V. K. (2002). Russkaya mental'nost': proiskhozhdenie, priroda, sotsiokul'turnye proyavleniya, Izhevsk: UDGU, 238s. 
Edición Especial Special Issue Octubre 2019 DOI: https://doi.org/10.17993/3ctic.2019.83-2.30-43 


$$
\text { /3/ }
$$




\section{NON-REFOULMENT AND AGE ASSESSMENT OF MINORS}

Kamila Danilovna Shaibakova

Kazan Federal University, Kazan, Russia.

Adel Ilsiyarovich Abdullin

Kazan Federal University, Kazan, Russia.

E-mail: kamila.shaibakova@gmail.com

Recepción: 05/08/2019 Aceptación: 09/09/2019 Publicación: 23/10/2019

\section{Gitación sugerida:}

Shaibakova, K.D. y Abdullin, A.I. (2019). Non-refoulment and age assessment of minors. 3C TIC. Cuadernos de desarrollo aplicados a las TIC. Edición Especial, Octubre 2019, 44-57. doi: https://doi.org/10.17993/3ctic.2019.83-2.44-57

Suggested citation:

Shaibakova, K.D. \& Abdullin, A.I. (2019). Non-refoulment and age assessment of minors. 3C TIC. Cuadernos de desarrollo aplicados a las TIC. Special Issue, October 2019, 4457. doi: https://doi.org/10.17993/3ctic.2019.83-2.44-57 


\section{ABSTRACT}

Situations when legal framework overlaps with the other areas sometimes rise the important questions. The age assessment is one of those areas where medical age determination directly affects human rights. A public entity uses a person's age to determine the age of a person in the absence of legal evidence. Medical age assessment applies more frequently in the asylum cases when unaccompanied minors arrive in a country where he/she seeks asylum. It is claimed that minors might not be fully honest concerning their age as being minor ease the application process. This is one of the reasons why medical assessment is required. However, often the assessment is not correct, and minors are declared of the full legal age. In addition, ways the medical assessment is carries could violate the rights per se. Therefore, often minors being surrendered or deported to the countries where the risks exist in reversal of the principle of no refund.

\section{KEYWORDS}

Age assessment, Non-refoulment, Refugee, Asylum, Minor, Children, Human rights. 


\section{INTRODUCTION}

The asylum-seeking process often became a tool for abuses. Immigration officers and social workers frequently challenge the age and reasons for asylum, claiming that information might not be truthful. When children come to the territory of a host state unaccompanied and without valid identification papers, the need of age assessment often arises. However, often the assessment is not correct, and minors are declared of the full legal age. Therefore, often minors being surrendered or deported to the countries where the risks exist in reversal of the essence of non-refund. However, age determination is flawed on the system. The medical procedures often dangerous for the health of a child and cannot produce any credible results. The interviews and conversation with social workers cannot give a definite answer just as in no personal circumstance they are not considered ethnic and cultural characteristics. Therefore, the system requires changes and improvements.

\section{METHODS}

The research question that is important to answer is does age assessment of minors violates certain human rights? The research question is of a descriptive and normative character. It is important to identify the type of the research question in order to choose the most appropriate research design. The first part of the research question is a descriptive as it examines how the law is (or lex lata). The article is looking at the existing law and jurisprudence of national, regional and international judicial bodies. The case study helps to explain both the process and consequences of a legal phenomenon via complete observation and analysis of the cases at stake. The European countries use the age assessment extensively; therefore, the example of the EU relevant to the article. In order to conduct a proper literature review, it is highly important to understand what the role of the literature is. Due to the type of the research question and the traditional legal nature of the research, academic literature is of a paramount importance. The 
research question could technically be answered based on the analysis of the case-law alone, however, the academic literature provides relevant background information and introduces the existent perspectives on the issue.

\section{RESULTS AND DISCUSSION}

Legal framework. The medical assessment is important in order to give an opportunity to enjoy a wide range of rights. The appropriate protection regime applies to asylum-seeker children, who are provided with residence, education, health care and supportive legal provisions to prohibit child detention, although they do not belong to persons over the age of eighteen; Adults should be arrested and made homeless. (Feltz, 2015; Kheirabadi \& Mirzaei, 2019).

The rights of the Convention on Refugees, undocumented children and lonely children are taken away from their families. (hereinafter - RC). Refugee extradition to countries where his life and liberty are threatened on grounds of nationality, race, religion, membership of a particular social group or group of differing political views, is regulated in Article $31 \mathrm{RC}$ with the content of the refugee return ban. Art. 22 RG prohibits general discrimination. Children with or without guardians seeking asylum may enjoy the protection and humanitarian assistance provided for in Article 5 of the Convention on the Rights of the Child. In addition, the best interests of refugee children and their assessment of their age should be considered in all childcare activities.

Ensuring that the child is properly identified for the rights mentioned above is very important. So when refugee children are identified for countries, they should be immediately identified and separated (Costello \& Hancox, 2015; Kashisaz \& Mobaraki, 2018). The identification measures may include an age assessment (Roscam Abbing, 2011; Kutuev et al., 2017). For example, a grandfather and his child apply for international convention support, according to the mental state, age and puberty the child must research if is a margin of interpretation, must be given the benefit of the doubt, the person who claims to be a minor. 
In order to assess age, different medical approaches have been taken in different countries. Medical tests that include measurements of puberty or radiological growth are most commonly used, the medial ends of both collarbones.

\section{Approaches}

Compared to the GRULAC and Pyle Atlas or the Tanner and Whitehouse pictures in order to determine the bone age of the child, Wrist X-rays are taken which is the most widely used medical methods.

$\mathrm{X}$-rays are taken in different ways in different countries; the Netherlands, X-rays of the spoke bone, in France, $\mathrm{x}$-rays of the left hand and wrist are taken and in Belgium, $\mathrm{x}$-ray of the entire dentistry, and $\mathrm{x}$-rays of the left wrist and collarbone which is fames a so-called triple test.

In Sweden, the National Board of Forensic Medicine has the task of carrying out the medical age assessments consisting of X-ray examinations of the knee joint and wisdom tooth. In practice, it is the dentist and doctor of the contracted healthcare provider who makes the assessment. In addition, interviews are also used in order to assess age.

\section{A problem}

Firstly, an age assessment has been widely criticized by the human rights lawyers as being unreliable and providing false results that could deprive a minor of international protection. For example, wrist x-ray indices based on the Caucasian American or British middle-class population are stated in the report by the French National Advisory Ethics Committee. It raises risks for children from other areas in the world.

Secondly, different countries take different approaches regarding the age determination; thus, while in one country a refugee can be declared a minor, in another country it might not be a case. Thirdly, the issue of free will; If every asylum seeker refuses to undergo a medical examination, they will be treated as an adult. Therefore, required informed consent to conduct an assessment 
cannot be given based on a free will of a person. This, of course, has drawn sharp criticism from the UNHCR, it is held that refusing medical examinations cannot prevent international protection for asylum children. (Separated Children in Europe Program, 2012).

Fourthly, most specialist doctors say that age estimation is an estimation and it is very difficult for those between the ages of 5 and 6 , while in other places it is very important. In fact, the medical methods can only estimate age, and this will make us fall into the margin of error. No reliable method for pediatricians at Royal College of England has been able to provide accurate age detection. They believe that there are several factors that influence the maturation and the process of skeletal maturation.

Assessment of age should be provided only with other available evidence that can be validated by the English Supreme Court if medical tests have failed to provide definitive proof of age and their most accurate measurement shows at least two years of error. Thus, the role of interviews conducted by social workers became an important step. While being a compromise, the interviews with social workers have been heavily criticized by various NGOs as being subjective interpretations.

An important case in this regard is the Case of Mubilanzila Mayeka and Kaniki Mitunga v. Belgium (Mayeka, 2006), considered by the ECH Rights. The wrong treatment of a child might constitute a reversal of Art. 3, the prohibition of torture and other graft. In that case, the 4-year-old girl, arrived in Belgium as a refugee child who is not a neighbor, he was detained along with other adults who caused him depression. Finally, the court concluded that this orphaned child, who is an illegal immigrant in a foreign country and is not supported by the family, will certainly be vulnerable. Secondly, the child was sent to the Republic of the Congo without any supervision of the child there (Mayeka, 2006; Qazvini, 2018; Eslami \& Ahmadi, 2019; Jabbari et al., 2019).

The interview assessment being called a good alternative for age determination raises new problems and challenges to human rights. Firstly, the social workers and personnel are not sufficiently trained to assess the age. Secondly, children 
who have been subjected to traumatic experiences, if you want to grow quickly to survive and do what they have been able to do. Subjective assessment can also be a case when the age assessed by a person, even if sufficiently trained. Thus, the language a child speaks sometimes affect the age assessment. Heaven Crawley gives examples of children who spoke English to the immigration officer or social workers, so it was decided that they are over 18 years old as they could speak good English (Feltz, 2015; Nakhaee \& Nasrabadi, 2019).

Undoubtedly, the medical age assessment can violate the human dignity of a person, however, it could directly affect the life of a minor as when declared an adult, a person denied the asylum and shall leave the country and be back to the home state where the high risks exist (Crawley, 2007). One of the recent cases was brought to attention in Sweden. In 2015, a boy applied for asylum. He conducted an age survey at the request of the immigration board, where the growth of his wisdom teeth and knee joint was examined. The Swedish National Board of Forensic Medicine concludes that he is 18 or older and his application for asylum was rejected. This case again showed that the margin of error is extremely high. It has been stated that one-third of all children assessed by the Swedish National Forensic Medicine in 2017 were incorrectly classified as adults. Secondly, often there is a contradiction between different types of medical assessments. In the case, the examination of the boy's knee joint showed that he was probably over the age of 18 while the assessment of the wisdom teeth supported him as a minor.

This case also shows that the medical assessment and the asylum decision can take years. And while being a minor while applying for asylum, a person could become an adult when the decision will

finally be made. This affects the law to demand and the right to therapy. Unaccompanied minors are particularly vulnerable: coming to a new country without family, speaking a different language, expertise and assessment of the social services. Therefore, judicial review should always be available and a possibility for appeal shall be explained. 
Vivien Felts' has shown a significant and credible result because age measurement is not recognized as harassment or torture, although the European Court of Human Rights has not yet filed a complaint about how to identify age. Notwithstanding all these interpretations, the examination of the asylum seeker's age can violate Article 8 of the European Convention on Human Rights. For countries that consider systematically evaluating age as the only option, and systematic formulation, it is likely that this device is not appropriate because of the high margin of error of the process and the importance of its consequences for the lives of these children. The absence of other remedies and revisions to the above will undermine the rights of refugee children in art 13 ECHR.

The Parliamentary Assembly of the CE brought attention to the potential risks when it comes to age determination: when there is a reasonable doubt, an independent authority shall make a second opinion, Methods consistent with ethical indicators in medicine that: It's less frequent shall be used and the presumption of the minority shall be guaranteed (UNHCR, 2014). The PACE highlighted that child protection shall be prioritized rather than immigration control.

There are still undocumented asylum seekers who are often neglected by governments during various forms of migration.

\section{SUMMARY}

Thus, this is a structural problem that in recent years has hit unaccompanied young people seeking asylum in Europe. Most of the decisions have been made based on unreliable data. International protection has thus in practice become inaccessible to many people from one of the most vulnerable groups globally, in reversal of both the EC and the treaty on the laws of the kid. In accordance with the international and the local legal framework, a child is entitled to protection. The incorrect age determination puts a principle of the best interest of a child 
at risk. It is better to pay more attention to raising the level of protection for the rights of refugee children when assessing their age from their circumstances, as well as issues such as their ethnic and cultural background.

\section{CONCLUSION}

The article demonstrated that the current state of the age assessment process needs to be changed and improved. Trying to make an asylum-seeking process more effective, the best interest of a child often neglected. The humiliating procedures violate human dignity, right to privacy. The hindrances to appeal the decision of refusing the asylum or deportation could violate the law to an impressive therapy besides justice. The ethical besides cultural specifications of a child rarely have been considered in addition to the application of the medical assessments that were created for American "Caucasian" population or for a British middleclass population. Unaccompanied minors are particularly vulnerable: coming to a new country without family, speaking a different language, expertise, often they do not know how to react and with these bring suspicions to the social and immigration services. Unfortunately, there are many cases when minors were denied asylum based on the wrong or superficial age assessment. They are sent back to the countries where considerable risks exist, therefore the principle of non-refoulment is also at stake.

\section{ACKNOWLEDGEMENTS}

The work is performed according to the Russian Government Program of Competitive Growth of Kazan Federal University. 


\section{REFERENCES}

Costello, C., \& Hancox, E. (2015). The Recast Asylum Procedures Directive 2013/32/EU: Caught between the Stereotypes of the Abusive Asylum Seeker and the Vulnerable Refugee. Forthcoming in V. Chetail, P. De Bruycker \& F. Maiani (eds) Reforming the Common European Asylum System: The New European Refugee Law (Martinus Nijhoff, 2015); Oxford Legal Studies Research Paper No. 33/2015. Retrieved from https://papers.ssrn.com/sol3/papers. cfm?abstract_id=2609897

Crawley, H. (2007). When is a Child not a Child? Asylum, Age Disputes and the Process of Age Assessment. London: Immigration Law Practitioners' Association (ILPA). Retrieved from https://pureportal.coventry.ac.uk/en/ publications / when-is-a-child-not-a-child-asylum-age-disputes-and-theprocess-o

Eslami, R., \& Ahmadi, S. (2019). Investigating the Role of Educational Media on Secondary School Students' Learning Process Improvement in Jahrom City. Journal of Humanities Insights, 03(01), 13-16. doi: https://doi.org/10.22034/ jhi.2019.80890

Feltz, V. (2015). Age assessment for unaccompanied minors. MdM International Network Head Office. Nantes, France. Retrieved from https://mdmeuroblog.files. wordpress.com/2014/01/age-determination-def.pdf

Jabbari, E., Charbaghi, Z., \& Dana, A. (2019). Investigating the Effects of Educational and Motivational Education at Different Levels on the Performance and Application of dart throwing. Fournal of Humanities Insights, 03(02), 37-44. doi: https://doi.org/10.22034/jhi.2019.80896

Kashisaz, S., \& Mobaraki, E. (2018). The Effects of Private Education Institutes in Providing Modern Financial Knowledge in Developing Countries. Fournal of Humanities Insights, 02(04), 172-178. doi: https://doi.org/10.22034/ jhi.2018.80887 
Kheirabadi, M. A., \& Mirzaei, Z. (2019). Descriptive valuation pattern in education and training system: a mixed study. Fournal of Humanities Insights, 03(01), 7-12. doi: https://doi.org/10.22034/jhi.2019.80889

Kutuev, R. A., Mashkin, N. A., Yevgrafova, O. G., Morozov, A. V., Zakharova, A. N., \& Parkhaev, V. T. (2017). Practical Recommendations on the Organization of Pedagogical Monitoring in Institutions of Vocational Education. International Electronic Fournal of Mathematics Education, 12(1), 3-13. Retrieved from https://www.iejme.com/article/practical-recommendationson-the-organization-of-pedagogical-monitoring-in-institutions-of

Mayeka, M. (2006). Kaniki Mitunga v. Belgium. Retrieved from https:/ /hudoc. echr.coe.int/FRE\#\{\%22itemid\%22:[\%22001-77447\%22]\}

Nakhaee, J., \& Nasrabadi, M. A. (2019). Strategies for Research-Centered Education of Architectural Designing by Examining the Research-Centered Activities of the Top Universities. Fournal of Humanities Insights, 3(2), 50-56. Retrieved from http://www.jhumanities.net/article_80898_dcaa625489b5f0 ff63aea1583a374ee8.pdf

Parliamentary Assembly | Assemblée Parlementaire. (2011). Unaccompanied children in Europe: issues of arrival, stay and return. Resolution 1810. Retrieved from http://assembly.coe.int/nw/xml/XRef/Xref-XML2HTMLen.asp?fileid $=17991$

Qazvini, F. (2018). Investigating the Relationship between Mental Health and Social Adjustment (Case Study: Ayatollah Rouhani Hospital in Babol). UCT Fournal of Social Sciences and Humanities Research, 6(2), 1-5. Retrieved from http:/ / www.uctjournals.com/archive/ujsshr/2018/June/1.pdf

Roscam Abbing, H. D. C. (2011). Age determination of unaccompanied asylum seeking minors in the European Union: a health law perspective. European journal of health law, 18(1), 11-25. doi: https://doi.org/10.1163/157180911X546101 
Separated Ghildren in Europe Programme. (2012). Position Paper on Age Assessment in the Context of Separated Children in Europe, 8. Retrieved from http:// www.refworld.org/docid/4ff535f52.html

UN High Commissioner for Refugees (UNHCR). (2014). Safe E Sound: what States can do to ensure respect for the best interests of unaccompanied and separated children in Europe. Retrieved from https://www.refworld.org/docid/5423da264.html

Zhampeisov, K., Balykbayev, T., Kolumbayeva, N. K. S., \& Aitpayeva, A. (2018). National Component of the Training Content of the Teachers in Kazakhstan's school. Opción, 34(85-2), 653-677. 
Edición Especial Special Issue Octubre 2019 DOI: https://doi.org/10.17993/3ctic.2019.83-2.44-57 


$$
\text { /4/ }
$$




\section{PRODUCTIVE WAYS OF FORMATION OF CHEMICAL AND BIOLOGICAL TERMS (IN ENGLISH, RUSSIAN AND TATAR LANGUAGES)}

Leila Aivazovna Nurgalieva Kazan Federal University, Kazan, Russia.

Lucia Munirovna Ibatulina Kazan Federal University, Kazan, Russia.

Venera Nafikovna Khisamova Kazan Federal University, Kazan, Russia.

Gitación sugerida:

Nurgalieva, L.A., Ibatulina, L.M. y Khisamova, V.N. (2019). Productive ways of formation of chemical and biological terms (in English, Russian and Tatar languages). 3C TIC. Cuadernos de desarrollo aplicados a las TIC. Edición Especial, Octubre 2019, 58-71. doi: https://doi.org/10.17993/3ctic.2019.83-2.58-71

\section{Suggested citation:}

Nurgalieva, L.A., Ibatulina, L.M. \& Khisamova, V.N. (2019). Productive ways of formation of chemical and biological terms (in English, Russian and Tatar languages). 3C TIC. Cuadernos de desarrollo aplicados a las TIC. Special Issue, October 2019, 58-71. doi: https://doi.org/10.17993/3ctic.2019.83-2.58-71 


\section{ABSTRACT}

Terminology is one of the most important problems of modern linguistics. The study of terminological systems of typologically different languages is of great scientific interest. The article deals with the productive methods of word formation in English, Russian and Tatar chemical and biological terminology on the example of suffixation, compounding, conversion and abbreviation. The purpose of the present study is to identify the features of these methods in the chemical and biological term systems of genetically unrelated and typologically diverse languages. The general models of word formation typical for the languages studied in this article are considered and presented.

\section{KEYWORDS}

Linguistics, Language, Words, Chemical terminology, Biological terminology, Word formation, English, Russian, Tatar. 


\section{INTRODUCTION}

In the modern world scientific knowledge plays an important role in the development of society. Due to the entry into global scientific and educational sphere, it is necessary to know features of academic style in English which is international language of scientific communication along with peculiarities of language of science in native language.

The importance of the question is proved by works of many researchers. Khuziahmetov and Valeev (2018) study peculiarities of bilingual learning of English and Tatar languages and pointed out that "it becomes necessary to pay special attention to the problem of the ability of students to effectively participate in the intercultural communication and a productive solution to this issue is the orientation toward bilingual education".

Khisamova, Motygoullina and Moullagaliev (2015), consider "the process of globalization and unification of the modern sciences into a new organized idea of using results of one scientific area in some different researches. For example, in revising the peculiarities of translating Anglo-American fiction into the Tatar language they can refer to the different layers of the linguistics, such as comparative linguistics, typology, translation theory and the real modality".

The research of terminology is among the most important problems of modern linguistics. In this regard studying term systems of typologically diverse languages is of great scientific interest.

Terminological vocabulary as a part of dictionary structure of language has several properties. It is the most developing part of dictionary structure in comparison with its other parts.

Study of terminology assumes not only consideration of terms and their functions, but also the analysis of sources and ways of their production. It is on the material of terminological vocabulary operation of laws of language, mainly of wordformation, is most shown (Kozhanova et al., 2017; Kheirabadi \& Mirzaei, 2019; Barati et al., 2018; Kashisaz \& Mobaraki, 2018). 
The science which deals with studying of terminology is called term study. The contribution to development of this discipline was made by scientists Vinogradov, Lott, Vinokur, Reformatsky, Budagov, Akhmanova, Piotrovsky and many others (Reformatskii, 1967).

Studying of peculiarities of word formation in language of chemistry and biology represents undoubted interest as the correct understanding of regularities of modern terminological word formation helps to carry out the process of term formation (Abilgaziyeva et al, 2018; Eslami \& Ahmadi, 2019; Jabbari et al., 2019; Nakhaee \& Nasrabadi, 2019).

Now word formation in terminology is a source of many linguistic researches devoted to various term systems on the basis of different languages.

\section{METHODS}

We understand as ways of word formation "receptions, methods of formation of new words from any material units of language by creation between them the word-formation relations" (Zakiev et al., 1995).

In this article we consider the most productive ways of formation of chemical and biological terms in the English, Russian and Tatar languages. Dictionaries of chemistry and biology in given languages are used in this article. The main method of our research is comparative analysis.

\section{RESULTS AND DISCUSSION}

One of the most productive ways to form chemical and biological terms in the English, Russian, and Tatar languages is affixation.

There are several terms formed by suffixation, that is, adding a suffix to the stem that is a morpheme which follows the root. Unlike prefixation, which affects the lexical-grammatical component of a word, suffixation, as a rule, allows to create words that relate to another part of speech or to another class of words. 
Let's consider a group of suffixes which new terms or words are formed from and which fulfills the role of a noun. In English, this group includes the suffixes -er, -or, -ent and -ant, which are used to form nouns denoting a person or mechanism with a specific action: to activate - activator, to absorb - absorbent, to carry - carrier. The same group includes the suffixes -ion, -ation, -ment, -ure, -age, -ence, - ance, -ing, with the help of which new terms are formed from verbs that express some concepts of nouns: exposure, oxidation, reaction.

In the formation of chemical and biological terms that perform the role of a noun in the Tatar language, the most productive suffixes are: -льљ//-лек, -гъци/геи (-кьги/-кеи), -чьљ/-че, -льљ/-ле, -чан/-чән, -ма/-мә, -ла/-лә, -лаштьгр/-ләштер. The suffix $-л ь љ /-л е к$ is a word-forming formant in many Turkic languages. With the help of this suffix in Tatar chemical and biological terms from nouns are formed, denoting the presence of quality, indicated by the manufacturing basis:

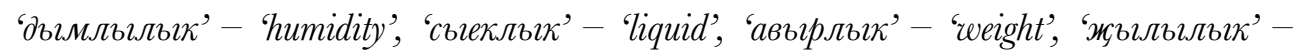
'heat', 'зурльик' - 'quantity' etc.

The suffix -льıк, can join the borrowed chemical or biological terms and form such words as: 'активлью' - 'activity' 'валентлью' 'valence', 'изоморфльюћ' 'isomorphism'.

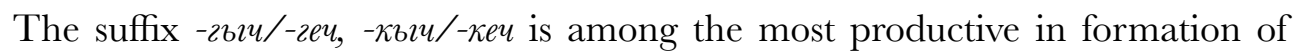
chemical and biological terms. It forms names of substances or medicines, expresses value of adaptation, installation or the tool for the action. For example: 'алмаштьгргъи' - 'substitute', 'беркеткеи' - 'fiхеr', 'йоткьич' - 'absorbent', 'оксидлаштьиргъи' - 'oxidant', etc.

In Russian a productive suffix for term formation is formed from stems of the borrowed nouns and meant branches of science: химия, биология, биохимия; chemical and biological processes and phenomena: автогамия, адаптаиия, аллотропия, дисперсия, диффузия, гомология, мезомерия. Тhе suffix - op is also productive. Nouns with this suffix are names of technical devices, apparatus: аспиратор, вентилятор, дистиллятор, конвертор, реактор and names of substances, materials which carry out some actions: активатор, анализатор, ингбитор, катализатор, репрессор, регулятор. 
The suffix -ени- means action as the phenomenon leading to any result: беление, брожение, бромирование, вальиевание, водопоглощение, галогенирование, давление. The suffix -ость in the terms formed from stems of descriptive adjectives means properties: аффинность, вирулентность, газоустойчивость, матовость, мелкопористость, мьилкость, неоднородность, основность, пластичность, продуктивность.

In works of many scientists compounding is mentioned as one of the most important means of language. In the examined languages this way of a term formation is one of old ways of creation of words which does not lose its productivity. The compounding is an important source of language vocabulary supplement. It is the process of composition of two or several stems in one compound word.

There is certain relationship between components of a compounding in the studied languages. It is coordinating or subordinating relationship. At the coordinating relations all components of a compound word are equal in the structural and semantic plan and make two structural-semantic centers. For example:

protein-ligand, enzyme-substrate;

винил-кушьллма, атом-төш, балчълк-бетон;

винил-соединение, глинобетон.

At the subordinating relations one component of the word is dominant and is the structural and grammatical center which means that it defines belonging to a certain lexical and grammatical category and a part of speech.

The subordinating relation is a main type of word connection in language. There are the following types of compounding with the subordinating relation of components: the attributive relation of components, the objective relation of components and the adverbial relation of components. 
In chemical and biological terminology of the studied languages compound words with the attributive relation of components prevail. The noun acts as the second component in them, the noun, an adjective, a pronoun, a numeral or a participle can be the first components.

Saidasheva (2006) pointed out that there are models of compounding common for English and Tatar. We found out that these models are also presented in Russian language.

They are:

1. Noun $+\operatorname{noun}(\mathrm{N}+\mathrm{N})$ :

unit cell, radioactivity, wavelength, oxidation-reduction, activation energy';

атом төше, балчвюк сөзгеи, аш тозьг, вак бөртеклелек, вак тишеклеклек, энже бөртеге;

аквасоединене, альфа-излучатель, газометр, гелеобразование, еж-рьба, жабаръъба.

2. Adjective + noun $(\mathrm{A}+\mathrm{N})$ :

acid-base, amino-terminal, free-energy, supercooling;

калай кисәге, тимер бактерияларе, түба калае;

железобетон.

3. Pronoun + noun $(\operatorname{Pr}+\mathrm{N})$ :

nonelectrolyte;

уздифбузия, узагач;

неэлектролит, самодиффузия.

4. Numeral + noun $(\mathrm{Num}+\mathrm{N})$ :

first-order reactions, two-component;

беркету, беркислотальи, икеузәкле бдйләнеш, икенигезле, өчнигезле кислоталар;

одноклеточнъие, двукисточник, двукрвилатка, триостренник, триперстовъее. 
5. Participle $+\operatorname{noun}(\mathrm{P}+\mathrm{N})$ :

boiling-point, branched-chain;

иинкланган тимер, чәчелүчәнек.

Along with a suffixation and a compounding, conversion in the studied languages is a highly productive way of a term formation. Conversion is the word formation process in which a word of one grammatical form becomes a word of another grammatical form without any changes to spelling or pronunciation. Thus conversion is a lexical and grammatical way of formation of new words. This way of enrichment of terminology is applied in English and Russian, and in Tatar languages.

In Tatar nouns, adjectives, adverbs, postpositions, particles, interjections and conjunctions are formed by means of conversion. The most productive is formation of nouns, adjectives, adverbs and postpositions (Zakiev et al., 1995).

In chemical terminology nouns denoting materials, metals, chemicals and their types become adjectives (Zakieva, 2011):

$$
\begin{gathered}
\text { Алтьлн - алтьгн 'gold-golden', көмеш-көмеш 'silver-silvery', энже - энже } \\
\text { 'pearl-pearly'. }
\end{gathered}
$$

As for English, the most productive is the model noun - verb. It is the only productive way of formation of verbs from nouns:

$$
\begin{aligned}
& \text { fuel, } n,-f u e l, v \\
& \text { water } n-\text { water, v } \\
& \text { heat, } n-\text { heat, v. }
\end{aligned}
$$

In Russian there are three types of conversion: substantivation, adjectivization and adverbialization. Substantivation is transition of a word from the category of adjectives in the category of nouns. Adjectivization is transition of words 
to the category of adjectives. As a rule, verbs and verbal forms (participles) form conversion base for formation of this sort of adjectives: дрессированныги, опубликованньй, закрьгтьй еtс.

Substantivation is characteristic feature for the language of biology. Such adjectives as альбатросовъге, баклановъе, веерокрьльие еtc. became nouns.

There are many abbreviations in language of chemistry and biology in English, Russian and Tatar. With the development of science many new terms in the form of compound words and phrases which come to terminological contraction appear.

There are various types of structural contractions. For the English, Russian and Tatar languages the general are graphic and lexical types.

Graphic contraction is use of symbols, reduction of words and phrases in a written language, at the same time in oral speech full forms are used. Symbols and signs belong to examples of graphic abbreviation in chemistry and biology: $C$ - Celsius degree of teтрегаture, температура, Цельсий градусьнда, температура по Цельсию; е. g. - for eхатрle; h.б.и. - һәм башка шушьиндъ; $d$-density, плотность, тьиъъзльи; $K$ teтperature of Kelvin, температура по Кельвину, температура, Кельвинда.

Lexical abbreviations are formed by means of process of simultaneous contraction and compounding. This way includes initial abbreviation. It is a way of word formation by addition of the reduced initial letters or sounds of a phrase. This contracted form is used also at pronunciation: ACFOR scale (Abundant Common Frequent Occasional Rare), ACTH (Adrenocorticotropic hormone), DNA (deoxyribonucleic acid), KE (kinetic energy), RNA (ribonucleic acid), STP (standard temperature and pressure), EFG (Epidermal Growth Factor); ATФ (аденозинтрифосфат), БАК (белок-активатор), ЗПА (зона поляризуюощей активности); РНК (рибонуклеин кислотась), ДНК (дезоксирибонуклеин кислотасъг), ХКС (хальгкара классификация системасы). 


\section{SUMMARY}

Suffixation is the most productive way of term formation in all three languages. The suffixes of noun formation with the same meaning occur in all of them. In compounding many complex chemical and biological terms is formed by addition of stems with the attributive relation of components where the first component is attribute of the second. This feature is characteristic for the English and Russian languages, and for Tatar. As for conversion which is common for all three languages in English first place is taken by the noun - verb model, in Russian noun - noun, and in Tatar highly productive model is noun - adjective. Abbreviation along with compounding and conversion represents a productive way of word formation. For the languages investigated in this article the general are such types of contractions as graphic and lexical.

\section{CONCLUSIONS}

We studied suffixation, compounding, conversion and abbreviation as the most productive ways of a term formation and identified the features of these methods of word formation in the chemical and biological term systems of three genetically unrelated and typologically diverse languages. Suffixation is the most productive way of term formation in them. The general models of word composition typical for the languages studied in this article are considered and presented. There are differences in models that are productive for each language in case of conversion. In the presentation of the abbreviation we showed models which are common for the English, Russian and Tatar languages.

\section{ACKNOWLEDGEMENTS}

The work is performed according to the Russian Government Program of Competitive Growth of Kazan Federal University. 


\section{REFERENCES}

Abilgaziyeva, Z. K., Janzakova, S. I., \& Nurgaliyeva, S. A. (2018). Speech activity among the junior students in teaching foreign languages. Opción, 34(85-2), 627-652.

Barati, M., Bahremand Joo, S., \& Mohammadi Aria, A. (2018). The effect of metacognitive beliefs and self-regulation strategies on students' academic motivation. UCT Journal of Social Sciences and Humanities Research, 6(1), 1823. Retrieved from http://www.globsci.com/index.php/ytuyk/article/ viewFile/527/516

Eslami, R., \& Ahmadi, S. (2019). Investigating the Role of Educational Media on Secondary School Students' Learning Process Improvement in Jahrom City. Fournal of Humanities Insights, 03(01), 13-16. doi: https://doi.org/10.22034/ jhi.2019.80890

Jabbari, E., Charbaghi, Z., \& Dana, A. (2019). Investigating the Effects of Educational and Motivational Education at Different Levels on the Performance and Application of dart throwing. Fournal of Humanities Insights, 03(02), 37-44. doi: https://doi.org/10.22034/jhi.2019.80896

Kashisaz, S., \& Mobaraki, E. (2018). The Effects of Private Education Institutes in Providing Modern Financial Knowledge in Developing Countries. Fournal of Humanities Insights, 02(04), 172-178. doi: https://doi.org/10.22034/ jhi.2018.80887

Kheirabadi, M. A., \& Mirzaei, Z. (2019). Descriptive valuation pattern in education and training system: a mixed study. Fournal of Humanities Insights, 03(01), 7-12. doi: https://doi.org/10.22034/jhi.2019.80889

Khisamova, V., Motygoullina, Z., \& Moullagaliev, N. (2015). Expression of the fiction in the material of «The catcher in the rye» by David Salinger and its translation into the Tatar language. Fournal of Language and Literature, 3(6), 140-143. 
Khuziahmetov, A. N., \& Valeev, A. A. (2018). Advantages of bilingual training in national schools. XLinguae, 11(1), 114-125. doi: https://doi.org/10.18355/ XL.2018.11.01.11

Kozhanova, M. B., Svechnikova, N. V., Akhmetzyanova, G. N., Kondrashova, E. N., Maksimova, N. L., \& Zakharova, Z. A. (2017). Psycho-Pedagogical Conditions of Professional Culture Development of a University Professor. International Electronic fournal of Mathematics Education, 12(1), 15-23. Retrieved from https://www.iejme.com/article/psycho-pedagogicalconditions-of-professional-culture-development-of-a-university-professor

Nakhaee, J., \& Nasrabadi, M. A. (2019). Strategies for Research-Centered Education of Architectural Designing by Examining the Research-Centered Activities of the Top Universities. Fournal of Humanities Insights, 3(02), 50-56. doi: https://doi.org/10.22034/jhi.2019.80898

Reformatskii, A. A. (1967). Termin kak chlen leksicheskoi sistemy iazyka [Term as a member of the lexical system of language]. Problemy strukturnoi lingvistiki. Moscow: Nauka.

Saidasheva, E. A. (2006). Slovoobrazovanie v tatarskom i angliiskom iazykakh na primere konversii i slovoslozheniia: Sopostavitel'nyi analiz [Word formation in the Tatar and English languages on the example of conversion and word composition: Comparative analysis].: avtoreferat dis. ... kand. filologicheskikh nauk: Kazan', - 24 s. (In Russian)

Zakiev, M. Z., Ganiev, F. A., \& Salimov, Kh. Kh. (1995). Tatarskaia grammatika [Tatar Grammar]. - T. 1: Vvedenie. Fonetika. Fonologiia. Prosodika. Grafika i orfografiia. Orfoepiia. Osnovnye poniatiia grammatiki. Morfemika. Morfonologiia. Slovoobrazovanie. 583 p.

Zakieva, Z. R. (2011). Sposoby slovoobrazovaniia kak faktor sistemnosti terminologii khimii $\mathrm{v}$ tatarskom iazyke [Methods of word formation as a factor of systematic terminology of chemistry in the Tatar language]. Vestnik ChelGU, 8 . 
Edición Especial Special Issue Octubre 2019 DOI: https://doi.org/10.17993/3ctic.2019.83-2.58-71 


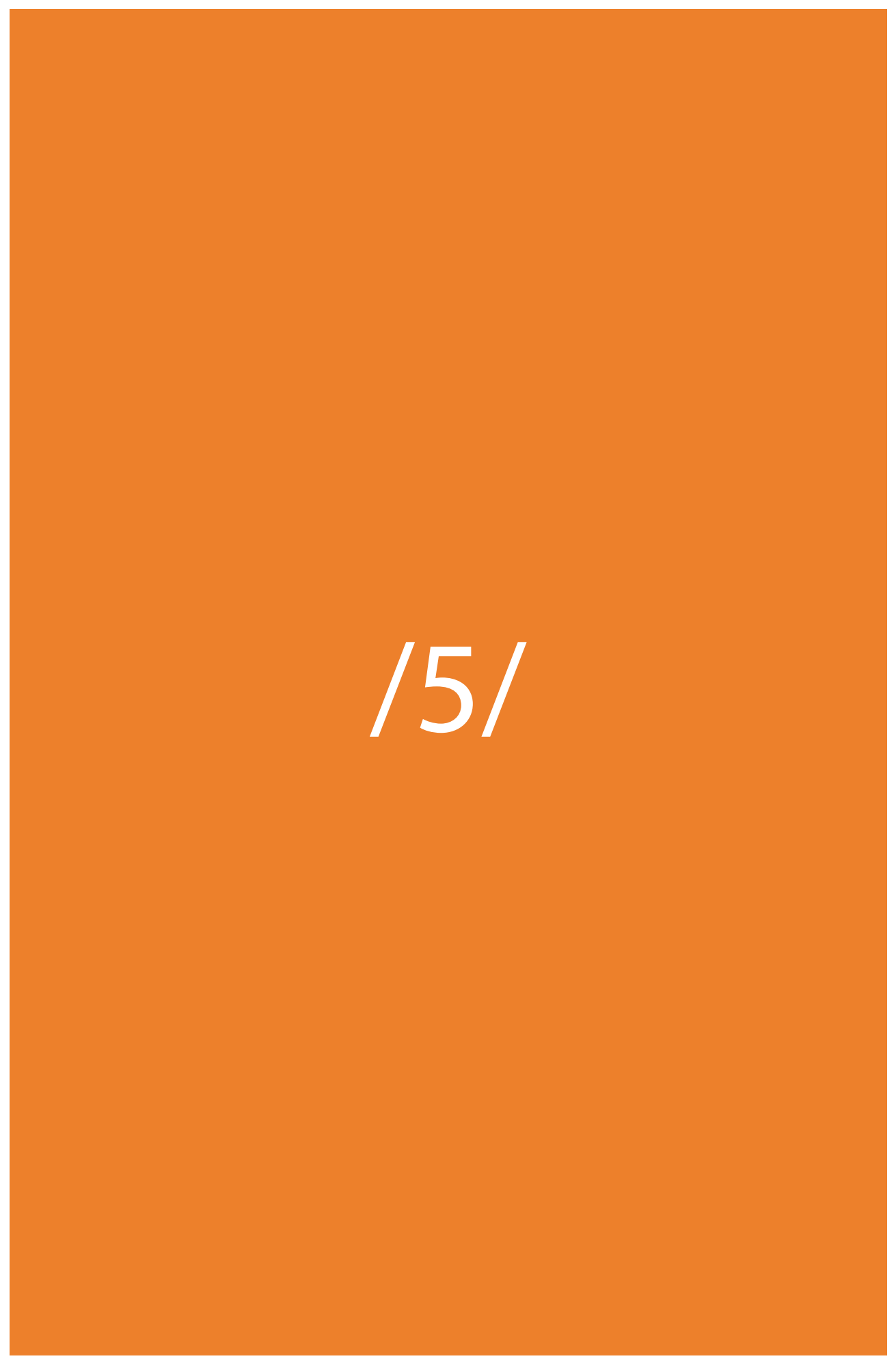




\section{THE CONCEPT "STUDENT" IN THE RUSSIAN AND GERMAN LINGUOCULTURES}

Dilyara Marsovna Sadykova

Kazan Federal University, Kazan, Russia.

Tatiana Yakovlevna Zaglyadkina

Kazan Federal University, Kazan, Russia.

Olga Valerevna Akimova

Kazan Federal University, Kazan, Russia.

Alfiya Nailevna Zaripova Kazan Federal University, Kazan, Russia.

E-mail: lelpam@mail.ru

Recepción: 05/08/2019 Aceptación: 09/09/2019 Publicación: 23/10/2019

Gitación sugerida:

Sadykova, D.M., Zaglyadkina, T.Y., Akimova, O.V. y Zaripova, A.N. (2019). The concept "student" in the Russian and German linguocultures. 3C TIC. Cuadernos de desarrollo aplicados a las TIC. Edición Especial, Octubre 2019, 72-89. doi: https://doi. org/10.17993/3ctic.2019.83-2.72-89

\section{Suggested citation:}

Sadykova, D.M., Zaglyadkina, T.Y., Akimova, O.V. \& Zaripova, A.N. (2019). The concept "student" in the Russian and German linguocultures. 3C TIC. Cuadernos de desarrollo aplicados a las TIC. Special Issue, October 2019, 72-89. doi: https://doi. org/10.17993/3ctic.2019.83-2.72-89 


\section{ABSTRACT}

The research rationale for the problem under study is in the profound changes which happened recently in Russia and affected the educational sphere and influenced the development of the Russian language, in particular the activisation of the metaphorical statements use processes in academic discourse. The purpose of the article lies in consideration of metaphorical diffuseness of the academic concept "Student" in the Russian and German linguocultures. The leading method in this research is the analysis of metaphorical diffuseness of the above-mentioned concept on the basis of the analysis of lexical units of full text databases of the German and Russian media, fiction, and Internet communication. As a result of the performed analysis it was revealed that in language picture of the world the appeal to the concept "Student" is quite popular. The figurative component of the concept is clearly expressed. But for language consciousness the most relevant is the German concept as its extra-zone includes some associations which were not found in the Russian language picture of the world.

The material of the article can be useful in Lexicology of the German and Russian languages, in training courses on cross-cultural communication, regional geography and linguistic and cultural studies of Russia and Germany, in practice of the Russian and German academic communication.

\section{KEYWORDS}

Language, Linguistics, Student, Concept, Higher education, Analysis, Lexeme. 


\section{INTRODUCTION}

\subsection{THE RELEVANCE OF THE PROBLEM}

At present in the era of globalization we are all witnesses and participants of the process of interpenetration and interaction of different cultures, which is naturally reflected in the language changes (Kalegina, Takhtarova, \& Zaglyadkina, 2015). The profound changes which occurred recently in Russia affected all spheres of social, political and economic development and engaged the educational sphere as well. Public changes of this sort influence development of language, in particular they intensify processes of the use of metaphorical expressions in the academic discourse.

The metaphor is one of the most widespread ways of lexical and also phraseological replenishment of language stock (Golshtejn \& Kerimov, 2008). The intensity of functioning of any concept is expressed in the sum of its two indicators - the nominative density and metaphorical diffuseness (Sly`shkin, 2004). Metaphorical expressions reflect the ideas of modern Russian reality and also form this representation (Shhurina, 2008). According to Lakoff and Johnson the metaphor penetrates all our everyday life and are intergrated not only in language, but also in thought and action (Lakoff \& Dzhonson, 1990). In the research of metaphorical expressions, the attention focuses, first of all, on how this phenomenon is used in the course of human communication (Kubryakova, 2004). Meanwhile, each language has inner peculiarities which challenge its learners along with its native speakers (Babenko, 2015).

\subsection{RESEARCH HYPOTHESIS}

In Russian and German linguocultures there are academic conceptual spheres which are manifested in the language system, in the associative and verbal network and in the communicative process, have national specific features and are amenable to a comparative linguistic research. The concept entering the academic sphere of concepts is the concept "Student". 


\section{METHODS}

\subsection{RESEARCH PROBLEMS}

In the research the following problems were being solved: 1) the analysis of metaphorical diffuseness of the concept "Student" on the basis of consideration of lexical units in full text databases of the German and Russian media, fiction, Internet communication; 2) the determination of similarities and differences in the concept "Student" manifestation in the German and Russian the linguocultures; 3) the analysis of the obtained results.

\subsection{THEORETICAL AND EMPIRICAL METHODS}

The conducted analysis is based on the principles of linguoculturological approach. The following methods were used:

- Theoretical - the analysis of the concept "Student" metaphorical diffuseness examples collected from various sources, analysis and generalisation of the conceptual description experience, synthesis;

- Empirical - comparison of the lexical units having metaphorical potential in the German and Russian the linguocultures and their interpretation.

\subsection{BASE OF THE RESEARCH}

The full text databases of the German and Russian media, Internet communication and fiction were research material. The text fragments which contain the metaphorical expressions based on the academic concept "Student" became the units of the research. 


\section{RESULTS AND DISCUSSION}

\subsection{METAPHORICAL DIFFUSENESS OF THE CONCEPT "STUDENT" IN THE RUSSIAN LINGUOCULTURE}

1. The concept "Student" found its embodiment in the metaphorical expression вечный студент. On the one hand the students who study many years in a higher education institution, but owing to their laziness cannot possibly finish their study are called this way (3)-(4). And on the other hand it is people who have insuperable desire to study, finishing one educational institution, they come to another, constantly craving new goals achievement (1)-(2).

The concept "Student" extrazone includes the following associations:

• вечный студент $\rightarrow$ thirst for knowledge:

(1) - Натали не только знаменитая не по годам актриса, но и... вечный студент. Не в том смысле, что не может сдать экзамены и перейти на другой курс. Наоборот, девушка обуреваема жаждой знаний. Гарварда ей не хватило, и недавно она поступила в Иерусалимский университет (Komsomolskaya Pravda). Я вечный студент и мне не стыдно. Я давно понял, что учиться намного интереснее, чем ходить на работу (https:// riamo.ru/article/263758).

(2) - Наконец в коридоре на него навалился, как медведь, Павел Иванович Мамаев, «вечный студент», уже не очень молодой, грузный, успевший побывать и в Юрьевском и в Варшавском университетах (Pavel Nilin. "Interestnaya zhizn"). 
• вечный студент $\rightarrow$ poor performance:

(3) - Один из экзаменов бедолаге пришлось сдавать аж с восьмого захода. Когда он, набив шпорами карманы, в очередной раз отправился на экзекуцию в альма-матер, зловредный препод заставил его вытряхнуть их на стол. Оставив «вечного студента» наедине с чистым листом бумаги, вышел из аудитории (Trud).

(4) - В конце концов «вечный студент» получил-таки диплом заочника пединститута по специальности русский язык и литература (Trud).

The concept "Student" extrazone extends due to the formation of new bonds in it. So, the association "thirst for knowledge" is connected with the association "age" that is evident from the examples (1) and (2).

• вечный студент $\rightarrow$ life expectancy:

(5) - Если не загружать мозг работой, старческое слабоумие обеспечено. Поэтому долгожитель - это вечный студент, он обречен постоянно воспринимать и перерабатывать новую информацию (Trud).

It is necessary to train the brain to process information constantly not to become a senile person in old age. It is proved that people of brainwork die of strokes less often. So the person caring for his health has to turn into "вечный (lifelong) студент".

2. Also certain appearance is a characteristic of the student that is reflected in the language picture of the world. A large number of examples in the Russian linguoculture is associated with the metaphorical expression "студенческий вид”: 
(6) - Почему-то в левом верхнем углу зала публика сидела довольно плотно: слева парочка хрустела и жевала, справа допивали пиво, а сзади расположилась большая компания студенческого вида, тоже с пакетами и с банками, в веселом, приподнятом настроении. (N. Ryazantseva. "Kultpohod v kino").

(7) - Помню, тогда этот скромно одетый, студенческого вида парень, высокий, худой, с бетховенской шевелюрой, принес Виталию Ивановичу какой-то свой пейзаж (Muslim Magomayev. "Lyubov moya melodiya").

The metaphorical expression “студенческий вид” is implemented in several associations: age, appearance, behavior. In terms of appearance young people can be divided into two groups: either those who give little attention to the appearance, or those who are very concerned about the latest fashion. In their company, they often do not pay attention to conventions of society and live in the student's world.

\subsection{METAPHORICAL DIFFUSENESS OF THE CONCEPT "STUDENT" IN THE GERMAN LINGUOCULTURE}

1. The concept "Student" in the German linguoculture has more expanded metaphorical diffuseness. The metaphorical expression "ein ewiger Student" spread over the following associations expanding the concept borders. It is necessary to emphasize the following:

- ein ewiger Student $\rightarrow$ poor performance:

(8) - Swen Ritter war ein ewiger Student, der es einfach nicht schaffte, sein Studium der Wirtschaftsinformatik an der TU Ilmenau abzuschließen (Internet site SpeedProject).

(9) - Schon in Venedig spielte man auf verschiedene soziale Schichten an, die man alle ansprechen wollte. Die komischen Figuren dürfen reichlich Subversives von sich geben. Es gibt immer einen Hauptkomiker, bei uns ein ewiger Student. Der nie sein Diplom macht, weil er lieber säuft als studiert (Welt online). 
Considering that the German educational system does not provide accurate time frames for the graduation from a higher education institution, it is poor performance that does not allow the German students to finish studies in an educational institution.

- ein ewiger Student $\rightarrow$ thirst for knowledge:

(10)-Der Ex-Creed und jetzt Alter Bridge Gitarrist Mark Tremonti gab dem US Magazin «Guitan ein Interview, dass speziell für Gitarrenfreaks sehr interessant sein dürfte. Der Mann am Schlagbrett erzählt von seiner Technik, dem Klang und das er ewiger Student seiner eigenen Gitarre geworden ist (Welt online).

(11) - Der vielseitigste Musiker unserer Zeit feierte im Funi seinen sechzigsten Geburtstag - David Geringas. Andere Menschen denken in dem Alter an den Ruhestand, doch der Ausnahme-Cellist sagt von sich: "Ich bin ein ewiger Student. Ich habe immer das Gefühl, dass etwas beginnt». So ist er ständig auf der Suche nach neuen Eindrücken, Aufgaben und Herausforderungen (Internet site Nordkultur.de.).

- ein ewiger Student $\rightarrow$ bashfulness:

(12) - Ich bin Dian Keto, 27 Jahre, komme aus dem kühlen Norden. Bin hier Student und ich sag euch, dass ist' ne echt geile Zeit. Doch leider bin ich nächstes Jahr fertig und muss aufgrund der Arbeitssituation aus dem schönen meerumschlungenen Bundesland weg. Ich möchte nicht, dass ihr denkt ich wär ein ewiger Student aufgrund meines fortgeschrittenen Alters. War vorher 4 Jahre Soldat (Stuttgarter Nachrichten online).

While, for example, in France or in England and also in Russia students graduate from a higher educational institution at 22-23 and begin to work, in Germany it happens approximately at 27-28. It is possible to notice that this fact is reflected in the German linguoculture where the metaphorical expression "ein ewiger Student" has a little negative shade of meaning. In example (12) it is possible to see that the young man feels uncomfortable that he leaves the walls of the university at 27 .

- ein ewiger Student $\rightarrow$ traits of character: 
(13) - Er sieht aus und wirkt wie ein ewiger Student, sehr sympathish und immer freundlich (Welt online).

(14) - Der Mitbewohner ist sehr ein ruhiger Mensch, man sieht und hört ihn kaum, ein sog. alter verkrachter ewiger Student... (Welt online).

In the German linguoculture there has been created a certain image of "ein ewiger (lifelong) Student" which is justified in language by a large number of adjectives with an evaluating component as, for example, in (13) - (16):

(15) - Philippe ist schüchtern, weltfremd, verträumt. Ein ewiger Student, der wiewohl gut einiges über dreißig Fahre als noch immer an einer verschrobenen Dissertation über den Weltraumpionier Ziolkowski werkelt und noch immer bei seiner Mutter wohnt (Интернет - сайт http://www.cineman.ch/movie/2004).

(16) - Er ist ein ewiger Student, gut organisiert, dem allerdings die Lebenserfahrung fehlt (Welt online).

The image of "ein ewiger Student" is characterised by such adjectives as nice, friendly, quiet, timid, fanciful, well organized. Comparing these two metaphorical expressions in the two linguocultures, it should be noted that the number of the adjectives carrying any assessment in the Russian linguoculture is much fewer. It is possible to note the following adjectives: не молодой, грузный, скромно одетый. In the German linguoculture the traits of character of "ein ewiger Student" are more evaluated, and in the Russian - age data.

- ein ewiger Student $\rightarrow$ money

Concerning difficult financial circumstances of the students in the German linguoculture there are many jokes as, for example, in (17):

(17) - Ein ewiger Student fragt den anderen: «Sag mal, wie machst du das eigentlich, wovon lebst du?» - «Ich schreibe!» - "Oh, interessant, und was schreibst du?» fragt der erste. «Briefe, nach Hause, dass ich Geld brauche!» (Internet site GesundheitPro.de.). 
The "ein ewiger" students characterised not only by difficult financial circumstances, but also by aspiration to improve their financial position and also by ingenuity in earning money. They try to solve a financial problem together. It is seen in examples (18) and (19).

(18) - Van Wilder, ewiger Student und cooler Campuskцnig von Coolidge College hat ein Problem, als ihm sein Vater den Scheck streicht. Der wilde Wilder macht kurzerhand sein Hobby zum Beruf und organisiert Parties gegen Geld. «Nimm das Leben nicht so ernst», lautet seine Devise (Stuttgarter Nachrichten online).

(19) - Ich war ein sogenannter ewiger Student. Zusammen mit Freunden habe ich Kabarett gemacht und hatte eine Theatergruppe, um an Geld zu kommen (Jaap van Leeuwen. Portrait: Paul Dijkstra aus Utrecht - Wie ein Ideal gebrauchsfähig wird).

The examples of the same kind were not found in the Russian linguoculture.

- ein ewiger Student $\rightarrow$ appearance

(20) - Er wirkt wie ein ewiger Student. Nickelbrille, zerknittertes Leinensakko, Jeans, bequeme Straßentreter (Berliner Kurier).

(21) - Daniel Bielenstein ist rein äußerlich der Typ «ewiger Student» oder Referendar. Der Bartträger hat listig-lüstige braune Augen hinter einer Hornbrille. Das schüttere Haar ist intellektuellenmäßig zauselig unfriesiert. Zum braunen Allwetterschuh trägt er in diesen Schmuddeltagen eine beige Cordhose, darüber ein dunkelblaues Hemd zum anthrazitfarbenen Fackett - Modepäpste wie Armani und Co. wären entsetzt (Welt online).

The "ein ewiger Student" is characterised by negligence in clothes. It is comfort that is in the first place, and only then fashion comes. In the Russian linguoculture students either adhere to fashion, or do not pay any attention to it. 
2. The concept is the subject of continuous dynamic development which is influenced by the environment in which it interacts with other concepts. One association which is lacunary for the Russian culture is characteristic of the German linguoculture. The concept "Student" is connected with the concept "Car". Similar examples were not found in the Russian culture.

(22) - Das neue KA-Sondermodell «Student» soll ab sofort mit einem Listenpreis von rund 8000 Euro angeboten werden. (Süddeutsche Zeitung).

(23) - Schnell haben die Kölner aus dem Kleinwagen KA das Sondermodell «Student» gestrickt. (Welt online).

3. The concept "Student" served as a basis for metaphorical meaning of Studentenfutter (Futter - a forage (for the cattle), fodder; in colloquial language - food). In the German linguoculture Studentenfutter is associated with several options of this metaphorical expression use.

- Studentenfutter $\rightarrow$ food:

(24) - Studentenfutter ist ein idealer Pausensnack für Schule, Sport und Büro. Biologische Nüsse und Trockenfrüchte werden gemäß EU-Bio-Verordnung nicht mit chemischen oder synthetischen Mitteln behandelt. (Интернет-сайт naturkost.com).

Usually packets of nuts with raisins mixed with various dried fruits are called Studentenfutter. They are in great demand among school and university students. Most likely, the popularity of this product is caused, first of all, by its low price and high caloric content.

- Studentenfutter - cheap and quickly cooked food:

(25) - Keinen Plan, was Ihr essen sollt? Mensa zu?' Geld (fast) alle? In Cat's ultimativem Studentenkochbuch findet Ihr Studentenfutter pur: von der Vorspeise über Salate, Hauptgerichte, Desserts sowie Partyrezepte und vieles mehr - doch vor allem schnell, einfach und dem chronischen Geldmangel studentischer Portemonnaies angemessen. (Internet site Geizkragen). 
(26) - Dieses Gericht habe ich noch in Deutschland zubereitet, aus Zeitmangel habe ich es immer nicht aufgeladen. Da ich nun keine Studentin mehr bin, wird meine StudentenfutterSerie nächste Woche mit dem 6. Rezept enden. (Internet site Yahoo 360º).

As students always lack for money and time, it is extremely important for them that the process of cooking should be quick and cheap.

- Studentenfutter $\rightarrow$ finance

In this context Studentenfutter means, most likely, one of type of monetary investments into study,

In this context of Studentenfutter means, most likely, one of types of the monetary investments into study offered by local division of financial institution.

(27) - Studieren ohne Geldsorgen? Unser Studentenfutter $\times$ macht' $\boldsymbol{s}$ möglich! Mit unserem Studentenfutter $\times$ sichern Sie sich auf einen Schlag viele Vorteile, um sich voll und ganz auf Ihr Studium konzentrieren zu können. Sehen Sie selbst und vereinbaren Sie gleich einen Termin mit uns, denn wir garantieren mehr Studienerfolg durch mehr finanzielle Beweglichkeit! (Advertisement from Sparkasse Suedholstein).

4. It should be also noted the enrichment of the concept "Student" extra-zone due to the meaning transfer of the word functioning in the language several centuries ago to the modern linguoculture. Since the time of F. Schiller in the German language picture of the world the expression "Brotstudenten" is common (Brot - bread).

(28) - Ich genieße es, mit einem Dutzend Studenten in der Uni zu sitzen, der Professorin zu lauschen und angeregte Debatte zu führen. Ich mag mittlerweile sogar klassische Literatur und Klaviermusik. Ich bin kein Brotstudent, wie Schiller diejenigen nannte, die nur für ein «Amt» lernen und nicht mit den Wissenschaften «den Geist nur als Geist vergnügen» (Meine Welt im Ranzen. http://jan.twoday.net). 
(29) - Von unbeliebten Fammerprofessoren, Brotstudenten und philosophischen Köpfen: über das ewige Scheitern der Hochschule ( Süddeutsche Zeitung).

Recently expression of "Brotstudenten" became especially relevant in the light of the last transformations in the educational sphere in Europe. Still the debate on the Bologna program which entered uniform educational standards across the whole Europe continues. According to many the Bologna system turns all who begin their studies into the so-called Brotstudenten as they can be content only with the bachelor degree focused on a profession without research activities, merely learning what is given. But how in a year, having received the master's degree, they will be able to become those "philosophische Köpfe", nobody knows.

\section{SUMMARY}

A huge number of works is devoted to different researches of concepts and approaches to concept study are various. The concept is one of the most variously interpreted terms. In domestic linguistic researches the conceptual and culturological trends are of importance and have interdistsiplinarny character. In this regard it is necessary to consider the following authors' theories in concept study: Yu.S. Stepanov, A. Vezhbitskaya, N.D. Arutyunova, Yu.D. Apresyan, V.I. Karasik, G.G. Slyshkin, etc.

The analysis of the concept "Student" metaphorical diffuseness showed that the appeal to it is quite relevant both in the Russian and German linguocultures. The figurative component is most brightly expressed in the concept. For language consciousness the most relevant is the German concept as its extrazone includes such associations as food, money which were not found in the Russian language picture of the world. 
The academic concept "Student" considered by the authors had not been analysed earlier. The scientific novelty of this research lies in the analysis of metaphorical diffuseness of the given concept and obtaining the corresponding results allow us to summarize the following.

\section{CONCLUSIONS}

The student is an integral part of the educational process. Education, in turn, is one of the most important functions of culture as it provides its preservation and development (Bessarabova, 2007). In the context of the general paradigm of education, according to scientists of many countries, "education is a part of culture" (Bruner, 1996). And as the concept represents "cultural formation of the mental nature" with conceptual, figurative and valuable components (Karasik, 2002), we can tell that in a language picture of the world there was the next image of the "Student": The student in the Russian linguoculture is a slight young man who is not caring for the appearance, or on the contrary, accurately following fashion trends. This is a person of cheerful nature and high spirits. The student in the German linguoculture is a young man of 24-27, of normal constitution, often wearing spectacles, with a small beard, characterised by negligence in clothes, is unpretentious in food where, for whom simplicity and small price are the most important for it. The student is rather poor, but he aspires to earn money.

\section{ACKNOWLEDGEMENTS}

The work is performed according to the Russian Government Program of Competitive Growth of Kazan Federal University. 


\section{REFERENCES}

Kalegina, T.E, Takhtarova, S.S, \& Zaglyadkina, T.Y. (2015). Denglish and Franglais in the framework of the modern European linguistic landscape. Journal of Language and Literature, 6(3), 195-198.

Golshtejn, E.A., \& Kerimov, R. D. (2008). Konczeptual`ny`e metafory` v idiostile J.Rau. Lingvistika. Germenevtika. Konczeptologiya. Kemerovo: Kemerovskij poligraficheskij kombinat, 700 s., s.211

Sly`shkin, G.G. (2004). Lingvokul`turny`e konczepty`i metakonczepty`. Volgograd, Peremena, 340 s., s. 53

Shhurina, Yu. V. (2008). Komicheskaya metafora v sovremennom rossijskom media-diskurse. Lingvistika. Germenevtika. Konczeptologiya. Kemerovo: Kemerovskij poligraficheskij kombinat, 700 s., s.247

Lakoff, D., \& Dzhonson, M. (1990). Metafory`, kotory`mi my`zhivem.// Teoriya metafory`: Sb. statej/Pod redakcziej N.D. Arutyunovoj.-Progress, 387-416.

Kubryakova, E. S. (2004). Yazy`k i znanie. M:, Yazy`ki slavyanskoj kul`tury`.

Babenko, O. V. (2015). Language as a basic feature of ethnos uniting within the conditions of modern challenges, 6, 168-170. Retrieved from https:// www.researchgate.net/publication/298696969_Language_as_a_basic_ feature_of_ethnos_uniting_within_the_conditions_of_modern_challenges

Bessarabova, I.S. (2007). Polikul`turny j podkhod kak tendencziya razvitiya sovremennogo obrazovaniya. Menyayushhayasya kommunikacziya v menyayushhemsya mire: sb. statej / otv. red. G.G. Sly`shkin. Volgograd: FGOU VPO «Volgogradskaya akademiya gosudarstvennoj sluzhby»». Volgograd: Izd-vo FGOU VPO VAGSb s.132 
Bruner, J. S. (1996). The culture of Education. Cambridge, Mass.: Harvard University Press.

Karasik, V. I. (2002). Yazy 'kovoj krug: lichnost', konczepty`. Diskurs. Volgograd, Peremena. 
Edición Especial Special Issue Octubre 2019 DOI: https://doi.org/10.17993/3ctic.2019.83-2.72-89 



\section{THE TECHNIQUES OF TEACHING BUSINESS ENGLISH TO THE STUDENTS OF LINGUISTICS MAJOR}

Natalia Nikolaevna Bobyreva Kazan Federal University, Kazan, Russia.

Karina Muratovna Amirkhanova Kazan Federal University, Kazan, Russia.

E-mail: nathalienb@yandex.ru

Recepción: 05/08/2019 Aceptación: 09/09/2019 Publicación: 23/10/2019

\section{Citación sugerida:}

Bobyreva, N.N. y Amirkhanova, K.M. (2019). The techniques of teaching Business English to the students of linguistics major. 3C TIC. Cuadernos de desarrollo aplicados a las TIC. Edicion Especial, Octubre 2019, 90-105. doi: https://doi.org/10.17993/3ctic.2019.83-2.90-105

\section{Suggested citation:}

Bobyreva, N.N. \& Amirkhanova, K.M. (2019). The techniques of teaching Business English to the students of linguistics major. 3C TIC. Cuadernos de desarrollo aplicados a las TIC. Special Issue, October 2019, 90-105. doi: https://doi.org/10.17993/3ctic.2019.83-2.90-105 


\section{ABSTRACT}

The article describes the principles and methods of teaching Business English to the intending interpreters, translators and English teachers. The necessity to study the techniques of teaching it is conditioned by the importance of the English language as a means of international communication in the professional sphere. The authors of the article describe their experience in Business English teaching at the Higher School of Foreign Languages and Translation of Kazan (Volga Region) Federal University. The process of teaching Business English is designed to improve the students' knowledge of business terms, idioms; to improve the related language, communication and translation skills; to prepare for international certification; to develop motivation and leadership. The survey results and observation make it possible to conclude that learning Business English is one of the most significant components in the linguistic professional education, which is recommended to be included into the list of obligatory academic subjects.

\section{KEYWORDS}

Language, Linguistics, Learning, Student, Business English. 


\section{INTRODUCTION}

Different issues of university language education are within the focus interest of researchers. Finding effective educational approaches is possible via combining the classic and modern teaching-learning methods (Sirbu et al., 2015; Kheirabadi \& Mirzaei, 2019). The effectiveness of using integrated technologies, flipped learning and other innovative approaches and methods in the educational process is widely discussed (Abdullina et al., 2019; Kondrateva \& Nazarova, 2015; Kashisaz \& Mobarak, 2018). Electronic resources also serve as modern educational aids, which help to learn a subject in different aspects and develop skills, structuring and representing the full content of the subject, providing a wide range of task types and corresponding references (Akimova et al., 2015; Kurbanov et al., 2017; Nakhaee \& Nasrabadi, 2019).

Concerning the urgency of the present research, on the one hand, it is obvious that the significance of learning Business English in the modern world is out of question. Teachers and methodologists all over the world have created a lot of materials and tested various methods of teaching Business English. However, there are still some problematic issues, which concern teaching this subject to the students of linguistics major, i.e. future translators, interpreters and teachers of foreign languages.

Teaching this category of students presupposes the development of not only general cultural, linguistic and communicative competences, but also professional competences. For example, future translators are supposed to be able to translate texts connected with the business sphere, and future teachers are expected to have a clear understanding about how to teach Business English to different kinds of learners. Consequently, it can be argued that the process of teaching Business English to the students of linguistics major has its peculiarities. Firstly, as this category of students have no experience in business, teaching this subject could be regarded as soft CLIL (Bentley, 2011; Eslami \& Ahmadi, 2019; Mahdavi Panah \& Ghaderi, 2018). Besides, linguists are specialists in the sphere of intercultural 
communication, and it is hard to exaggerate their responsibility in completing the task of communicating successfully in the multicultural world (Zorina et al., 2016; Jabbari et al., 2019; Pussyrmanov et al, 2018).

\section{METHODS}

Business English related subjects are studied by the bachelor's degree students (the 3rd and 4th years of studies) and by master's degree students of linguistics major at Kazan (Volga Region) Federal University. These courses are optional, and the options are given to the students at the stage, when they have already mastered General English at the Upper-Intermediate level, when they have passed the obligatory theoretical courses of language theory, lexicology and translation studies. Learning these subjects is reasonable mostly for senior students, because they have enough knowledge and skills, and the necessity of finding a job is becoming urgent for them. Students already have a full idea about their future profession, they have their own view of all the aspects of their future professional activity.

There was a survey among 86 bachelor's and master's degree students of 7 academic groups. The programmes of their studies are: Translation and Translation Studies (bachelor's degree); Theory and Methods of Teaching Foreign Languages and Cultures (bachelor's and master's degrees); Management in Linguistic Education (master's degree). All the respondents study English as a second language. One of the targets of the survey was to get feedback, showing students' satisfaction with the quality of their curriculum and, thus, of the education they are getting, which is important in terms of independent evaluating of education quality (Yanova, 2015).

The students were asked to answer four questions: 1. How important it is to know Business English for your future profession? 2. Do you plan to translate in the business sphere? 3. How essential is it to pass the international certification in Business English for translators, interpreters and English teachers? 


\section{RESULTS AND DISCUSSION}

\subsection{LEARNING BUSINESS ENGLISH AS A SEPARATE ACADEMIC SUBJECT}

The aim of this subject is the development of a competence to communicate in a business environment. The content of this academic course includes the following areas:

1. "Basic notions of Business English", presenting Business vocabulary, grammar features, language skills useful for business, business-related topics;

2. "The style of official documents", introducing basic lexical, morphological, syntactical and compositional features;

3. "Translating bureaucratic style", covering the most essential peculiarities of the translation process in the corresponding sphere and the characteristics of the style influencing it, such as accuracy, standard character, directive character, impersonality, clear structure (Proshina, 2008).

4. "International certification in Business English", introducing the general information about Business English exams, their types and levels;

5. "Types of business letters and documents" covering the issues of business correspondence; the rules of making up contracts, CVs; writing application, request, credit, sales promotion letters; writing claims and adjustments, memos, emails, proposals and reports; maintaining joint venture correspondence and correspondence between colleagues in scientific spheres.

The topics of the practical classes are as follows: "Careers", "International Payments and Credits", "Contracts", "Marketing", "Business Management" and "Business Law". For each of the topics students do the following:

- learn a glossary with definitions;

- do lexical exercises; 
- $\quad$ read, retell, summarize, translate original texts;

- do reading tasks: answer questions, presupposing true/false marking or extended explanations;

- make up monologues and dialogues, employing role-play in typical situations of business communication, such as a job interview, project presentation, discussions with colleagues, negotiations;

- do writing tasks: letters, memos, emails, etc.

Thus, they train four language skills (reading, writing, listening and speaking) in relation to Business English.

One of the most important tasks of the discipline is to acquaint students with terms employed in the process of business communication. They learn basic economic and legal terminology. The examples are as follows:

- $\quad$ simple terms: assets; commodity, equity, inventory, liabilities, payables;

- compound terms: cash advance, currency conversion, market segmentation, mission statement, net profit, tax refund;

- business idioms: game plan, upper hand, learn the ropes, raise the bar, see eye to eye, ahead of the curve;

- abbreviations: $\boldsymbol{C M}$ contribution margin; $\boldsymbol{C} \boldsymbol{C V S}$ Credit Card Verification System; MPS master production schedule; OMS Order Management System.

The following types of vocabulary exercises are used: word formation; matching words to make collocations; gap filling; matching words with their definitions; deciphering abbreviations; translating phrases and sentences from English to Russian and vice versa.

During the term, every student compiles their own English-Russian Glossary of Business Terms, which is one of the final assessment tasks. Students include the vocabulary, which is regarded as new personally by them, study a dictionary example sentence and make up one of their own. 
Giving their answers to the first question of the questionnaire, about the importance of Business English for their future career, the vast majority (95\%) of respondents said that Business English skills are necessary for any linguist, but mostly for a translator or interpreter. 38\% of the respondents are sure that such language skills play a great role regardless of what job they will have in future. Business English knowledge and skills tend to be regarded not as professional competences, but as indicators of education, background, social status, and means of successful communication.

As for merely professional skills, the students mentioned the importance of the abilities to draw up documents, use business etiquette, communicate correctly with colleagues, partners and clients. According to the survey results, nearly half of the respondents could be interested in the job involving translating texts in the sphere of business, and they noted the importance of general erudition and special knowledge in the relevant field.

\subsection{EXAM PREPARATION FOR BUSINESS ENGLISH CERTIFICATE}

The modern labour market dictates the necessity to be professionally competitive and have an internationally recognized evidence of competences. Besides, such a recognition is needed in case of getting further education abroad.

The market environment demands teaching youth to demonstrate emotional intelligence and leadership skills, which is possible via developing their organizational inclination and communication skills (Zorina et al., 2018). To meet this social demand, a few international exams training courses were introduced for the 4th year bachelor's degree students, as well as for master's degree students. The respective disciplines are called Preparation for CAE, IELTS (Academic), BEC and TOEFL. Those are optional courses, which means that one of them is chosen by an academic group. So, BEC is the examination focused on Business English skills. 
The course for bachelors contains 4 modules: the first one gives general information about international examinations in Business English, and the three other modules cover three levels of BEC (Preliminary, Vantage and Higher) in four language skills. Though the formats of all the three levels are studied, the emphasis is on the Upper-Intermediate level due to the students' linguistic competences. As for the master's degree students, the content of the course in mainly the same, but it is structured in a different way: each module covers one of the four language skills at all levels of BEC. Within this course, also all the levels is considered, but more attention is paid to the Advanced level.

Both courses are aimed at giving theoretical supports and exam information, introducing the structure, content and procedure of the exams, as well as the main strategies, recommendations and techniques to pass them successfully. Much attention is paid to the practical activities, focusing on training. They are completed by students both in class and autonomously. Before completion, each task is described so that the students get comprehensive information about its type (for instance, multiple-choice, matching, note-taking, etc.), aims and tested skills. Besides, the recommended examination techniques are introduced. To provide the students with more information, they are given a reference to the authorized web site, where they can test their English and get sample tests (Cambridge Assessment English, 2019).

At any stage of the subject learning students may face some difficulties (both linguistic and methodological). Therefore, they are asked to give feedback on their strong and weak points and suggest some ways of compensating for these deficiencies.

Answering the question about the importance of international certification in Business English for translators, interpreters and English teachers, 92\% of respondents consider that a specialist in the sphere of linguistics is supposed to have a certificate proving their professional competence. The most frequently mentioned reasons are: confirmation of language skills level, improving the qualification, contributing to the professional growth, having an ability to 
compete at the international market (to find a job in a multinational company, to work or study abroad). A language certificate in the portfolio is a "symbol" of international recognition, which opens better career prospects and develops selfconfidence.

\subsection{EXTRACURRICULAR ACTIVITIES RELATED TO BUSINESS ENGLISH}

The project "I am a Linguist!" was launched in the Higher School of Foreign Languages and Translation to scaffold students in their desire to improve their language knowledge and skills and to guide them professionally. It includes many educational events as well as functioning of academic clubs.

The idea of organizing a contest in which students could compete in their Business English skills came with the necessity to give additional motivation to students. Though the optional courses are quite popular among students, we consider it to be essential to encourage their interest and inspire them. Therefore, the second year students, who are supposed to choose these subjects in future, are invited to take part in the contest.

This event has three stages (or rounds). In the first one all sophomores take part. Lecturers who teach the practical course of English hold this round with their academic groups. The task is usually given as a home assignment, that is a topic for a 2-3 minute monologue, in which participants give their hypothetic ideas about what kind of business they would start up if they had the chance. The talk is assessed by the following criteria: pronunciation (sounds and intonation); grammar (accuracy and complicatedness of structures); vocabulary (accuracy of the use of words, sophistication of lexis); discourse management (ability to speak about the topic in question in a logical way and for the right length of time); presentation skills (ability to speak and behave in public, including dress code). 
Basing on the scores, a lecturer recommends one of the students of the academic group to participate in the second round. It takes place in one week and presupposes completing the tasks on reading and listening of B1-B2 levels. The types of tasks include multiple choice, matching, note-taking. The participants with the 10 top scores are invited to take part in the third round.

In the final the participants get a task to make an oral essay. The topic is announced 30 minutes before performing in public. Students are supposed to give their opinion on a quotation of a famous person. For example: "Time is Money" (Benjamin Franklin); "An investment in knowledge pays the best interest" (Benjamin Franklin); "Let all your things have their places; let each part of your business have its time" (Benjamin Franklin); "The first duty of a human being is to find your real job and do it" (Charlotte Perkins Gilman); "Success has a simple formula: do your best, and people may like it" (Sam Ewing); "Doing your best at this moment puts you in the best place for the next moment" (Oprah Winfrey).

This round is held in a large room, where all those interested are invited. The order of participants is determined by the draw and their performance on the stage is organized in such a way that they don't hear the previous speakers, as they are invited into the room by the volunteers one by one. The 2-3 minute talks are assessed by a panel of lecturers, basing on the same criteria as in the first round.

\section{SUMMARY}

With reference to the work experience, observation, and results of the students' survey, we may conclude that the most serious challenges facing Business English lecturers are caused by students' poor knowledge of General English, insufficient language skills and lack of motivation. The favorable factors are students' personal interest, being oriented at finding opportunities to develop general (cognitive, cultural, communication) and special (professional) skills, being focused on high standards. 
The teachers' tasks are to consider individual interests and expectations of students, to facilitate the process of developing their talents and creative skills. Due to the changes at the labour market, in the social situation and academic environment, the techniques of teaching academic disciplines need to be reconsidered and updated.

\section{CONCLUSIONS}

Thus, modern professional linguistic education could offer better opportunities for learning Business English. One of them is including the subject into the list of obligatory courses. The experience of teaching it, accumulated by a great number of teachers and methodologists all over the world, has produced a lot of aids and methods, which could be employed while teaching students of Linguistics major. What should be taken into consideration by the university lecturers is that such students are supposed to get a more profound and extensive understanding of the subject than students getting non-linguistic professions or people attending courses of Business English at language schools.

The combination of the basic course of Business English, the course of preparation for an international examination and extracurricular activities contribute to educating a many-sided professional personality. The survey data proved that the targets of the academic subjects meet the interests, needs and expectations of future translators, interpreters and English teachers, as they see the real opportunities of how to use the corresponding knowledge and skills in their career.

\section{ACKNOWLEDGEMENTS}

The work is performed according to the Russian Government Program of Competitive Growth of Kazan Federal University. 


\section{REFERENCES}

Abdullina, L. R., Ageeva, A. V., \& Gabdreeva, N. V. (2019). Using the "Flipped Classroom" Model in the Teaching of the Theoretical Disciplines (French Language) at the University. XLinguae, 12(1), 161-169. doi: https:// doi.org/10.18355/XL.2019.12.01XL.12

Akimova, O., Bobyreva, N., Palutina, O., \& Pomortseva, N. (2015). Distance Language Education. Procedia-Social and Behavioral Sciences, 199, 348356. doi: https://doi.org/10.1016/j.sbspro.2015.07.558

Bentley, K. (2011). The Teaching Knowledge Test: Content and Language Integrated Learning Module. Cambridge: Cambridge University Press, 124.

Cambridge Assessment English. (2019). Retrieved from https://www. cambridgeenglish.org/

Eslami, R., \& Ahmadi, S. (2019). Investigating the Role of Educational Media on Secondary School Students' Learning Process Improvement in Jahrom City. Fournal of Humanities Insights, 3(01), 13-6. doi: https://doi.org/10.22034/ jhi.2019.80890

Jabbari, E., Charbaghi, Z., \& Dana A. (2019). Investigating the Effects of Educational and Motivational Education at Different Levels on the Performance and Application of dart throwing. Fournal of Humanities Insights, 3(02), 37-44. doi: https://doi.org/10.22034/jhi.2019.80896

Kashisaz, S., \& Mobarak, E. (2018). The Effects of Private Education Institutes in Providing Modern Financial Knowledge in Developing Countries. Fournal of Humanities Insights, 02(04), 172-8. doi: https://doi.org/10.22034/ jhi.2018.80887

Kheirabadi, M. A., \& Mirzaei, Z. (2019). Descriptive valuation pattern in education and training system: a mixed study. Fournal of Humanities Insights, 3(01), 7-12. doi: https://doi.org/10.22034/jhi.2019.80889 
Kondrateva, I., \& Nazarova, M. V. (2015). Integration of Science and Language in Teaching English. Fournal of English Language and Literature, 61(3), 63-68. doi: https://doi.org/10.7813/jll.2015/6-3/47

Kurbanov, R. A., Gurbanov, R. A. O., Belyalova, A. M., Maksimova, E. V., Leonteva, I. A., \& Sharonov, I. A. (2017). Practical Advice for Teaching of University Students the Mechanisms of Self-Government of Safe Behavior. International Electronic Fournal of Mathematics Education, 12(1), 35-42. Retrieved from https://www.iejme.com/article/practical-advice-for-teaching-ofuniversity-students-the-mechanisms-of-self-government-of-safe

Mahdavi Panah, M. \& Ghaderi, M. A. (2018). Undesirable Effects Of Procrastination From The Perspective Of Islamic Narrations. UCT Journal of Social Sciences and Humanities Research, 6(1), 9-12.

Nakhaee, J., \& Nasrabadi, M. A. (2019). Strategies for Research-Centered Education of Architectural Designing by Examining the ResearchCentered Activities of the Top Universities. Fournal of Humanities Insights, 3(02), 50-6. Retrieved from http://www.jhumanities.net/article_80898_ dcaa625489b5f0ff63aea1583a374ee8.pdf

Proshina, Z. G. (2008). The Theory of Translation (from English into Russian and from Russian into English"). Vladivostok: Far Eastern University. 276.

Pussyrmanov, N., Rystina, I., Bulegenova, B., Askeyeva, G., \& Gabdulina, B. (2018). President Nursultan Nazarbayevs program article "The course towards future: Modernization of public consciousness"-ideology, value and political aspects. Opción, 34(85-2), 824-837.

Sirbu, C. G., Tonea, E., Iancu, T., Pet, E., \& Popa, N. D. (2015). Aspects concerning the usage of modern methods for teaching-learning-evaluation in universities. Procedia-Social and Behavioral Sciences, 182, 550-554. doi: https:// doi.org/10.1016/j.sbspro.2015.04.777 
Yanova, N. (2015). Assessment of Satisfaction with the Quality of Education: Customer Satisfaction Index. Procedia-Social and Behavioral Sciences, 182, 566573.

Zorina, A. V., Vygodchikova, N. N., Gatin, R. G., Nazmutdinova, M. A., \& Gerasimova, O. Y. (2016). Multicultural Education of Multi-Ethnic Students at the Foreign Language Class. International Journal of Environmental and Science Education, 11(18), 10817-10827. Retrieved from https://eric. ed.gov/?id=EJ1120635

Zorina, A. V., Yarullina, A. S., Akhmetova, L. A., Shaimardanova, M. R., Nikishina, S. R., \& Garipova, A. A. (2018). Leadership in the University Student Environment: How to Become a Person-Oriented Leader. International Fournal of Instruction, 11(4), 271-286. doi: https://doi.org/10.12973/ iji.2018.11418a 
Edición Especial Special Issue Octubre 2019 DOI: https://doi.org/10.17993/3ctic.2019.83-2.90-105 


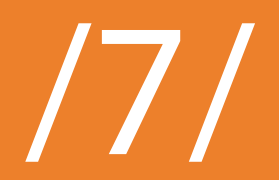




\section{REDUCING THE PROBLEM OF WAVEGUIDE EXCITATION BY CURRENTS IN CROSS- SECTION TO A SYSTEM OF INTEGRAL VOLTERRAEQUATIONS}

Angelina Markina

Kazan Federal University, Kazan, Russia.

Nikolai Pleshchinskii

Kazan Federal University, Kazan, Russia.

Dmitrii Tumakov

Kazan Federal University, Kazan, Russia.

E-mail:m8angelina@gmail.com

Recepción: 05/08/2019 Aceptación: 09/09/2019 Publicación: 23/10/2019

Gitación sugerida:

Markina, A., Pleshchinskii, N. y Tumakov, D. (2019). Reducing the problem of waveguide excitation by currents in cross-section to a system of integral volterra equations. $3 \mathrm{C}$ TIC. Cuadernos de desarrollo aplicados a las TIC. Edición Especial, Octubre 2019, 106-125. doi: https://doi.org/10.17993/3ctic.2019.83-2.106-125

Suggested citation:

Markina, A., Pleshchinskii, N. \& Tumakov, D. (2019).Reducing the problem of waveguide excitation by currents in cross-section to a system of integral volterra equations. 3C TIC. Cuadernos de desarrollo aplicados a las TIC. Special Issue, October 2019, 106-125. doi: https:// doi.org/10.17993/3ctic.2019.83-2.106-125 


\section{ABSTRACT}

The problem of excitation of a cylindrical metal waveguide by a source located in the cross section is considered. We assume that the source is surface currents on a flat, infinitely thin metal plate with a smooth boundary. The plate is connected to the generator of non-harmonic oscillations. The boundary of the cross section of a waveguide filled with a homogeneous dielectric is a closed piecewise-smooth contour. The initial physical problem is formulated as a mixed boundary problem for the system of the Maxwell equations. Components of the desired solution for the problem is presented in the form of a series in two sets of two-dimensional eigenfunctions of the Laplace operator. The first set of the eigenfunctions corresponds to the operator with Dirichlet boundary conditions, the second set to the operator with Neumann boundary conditions. We show that the expansion coefficients of the longitudinal components (components directed along the waveguide axis) of the electric and magnetic intensity vectors must be solutions to the jump problem for a system of telegraph equations. The problem of finding the unknown coefficients of the expansion of the longitudinal component of the vector of electric intensity is reduced to solving a system of the Volterra integral equations of the first kind with respect to the derivatives of the desired coefficients. The unknown coefficients of the expansion of the longitudinal component of the vector of magnetic intensity are found by solving a system of the Volterra integral equations of the second kind.

\section{KEYWORDS}

Metal waveguide, Wave excitation, Telegraph equation, Cross-sectional source, Volterra equation. 


\section{INTRODUCTION}

Metal waveguides are widely used in electronics and engineering. The study of such waveguide structures includes both the description of the set of eigenwaves and the search for the conditions of their excitation (Barybin, 2007). In particular, the excitation of oscillatory processes with specified characteristics in such structures is one of the tasks facing engineers.

In the case of a harmonic non-stationary electromagnetic field, the fundamentals of the theory of waveguides with metal walls were created in the middle of the last century (see, for example, works) (Samarskii \& Tikhonov, 1948; Samarskii \& Tikhonov, 1947). The problem of field excitation by currents given inside the waveguide was investigated in enough detail. The modern theory of excitation of waveguides of various types is presented in the review article (Solncev, 2009; Ghaderi \& Mahdavi Panah, 2018). For metal waveguides, there are cases when solutions to the problems of propagation and diffraction of eigenwaves can be obtained analytically (Collin, 1960; Mittra, 1971).

Various methods are used to excite waveguides. For example, in optical waveguides, geometric inhomogeneities on a dielectric are often used to excite oscillations by an incident external wave (Sun \& Wu, 2010; Shapochkin et al., 2017; Kheirabadi \& Mirzaei, 2019; Kashisaz \& Mobarak, 2018). For metal waveguides, adjacent transducer waves are used or, more often, probes inside the waveguide (Yirmiyahu, Niv, Biener, Kleiner, \& Hasman, 2007; Kong, 2002; Pan \& Li, 2013; Eslami \& Ahmadi, 2019; Jabbari et al., 2019; Nakhaee \& Nasrabadi, 2019). In this case, the probes can have both a simple dipole shape and a loop shape. Also, the natural waves are excited through the slits of the waveguide or through another conjugate waveguide (Sadiku, 2014). In this case, the waveguide itself can be both homogeneous and inhomogeneous filling (Bogolyubov et al., 2003; Islamov et al., 2017; Sailaukyzy et al., 2018).

In the present work, we consider the problem of the excitation of a cylindrical metal waveguide by currents on an infinitely thin metal plate located in cross section and connected to a generator. We assume that the waveguide cross section 
is bounded by a piecewise smooth curve. The non-harmonic electromagnetic field excited in the waveguide is sought as a solution to the jump problem for the Maxwell equations. We show that the longitudinal components of the field must be solutions of the system of telegraph equations. The jump problem for such the system of equations is reduced to the system of the Volterra integral equations.

\section{PROBLEM STATEMENT}

Let an infinite cylindrical waveguide with metal walls (Figure 1a) is filled with a homogeneous isotropic dielectric, and the $z$ axis is the longitudinal axis of the waveguide. Let its cross section $\Omega(z=0)$ be bounded by a piecewise-smooth contour $\mathrm{C}$ and consists of two parts: $M$ and $\mathcal{N}$ (Figure 1b), moreover, $\Omega:=\bar{M} \cup N$. Part $M$ is an infinitely thin ideally conducting plate connected to a generator of highfrequency non-harmonic oscillations. The currents arising on the plate excite an electromagnetic field in the waveguide. It is necessary to find this field.

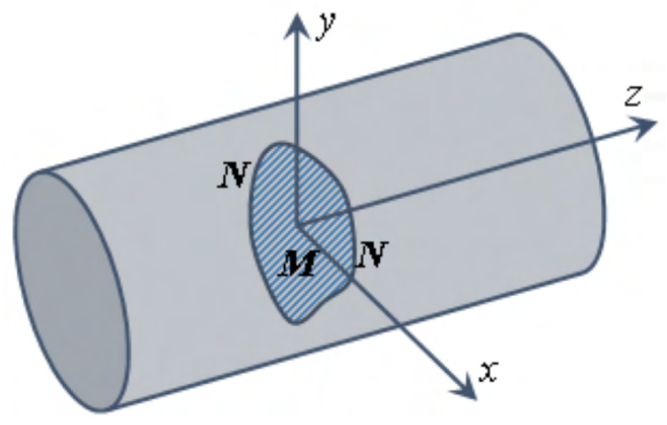

A

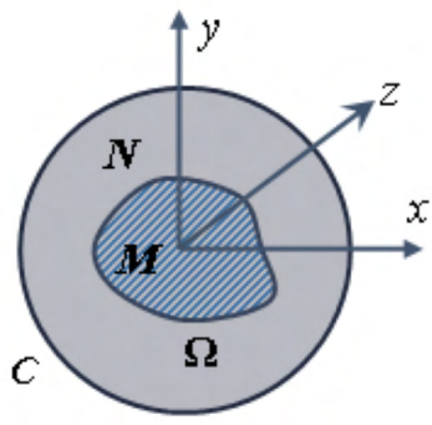

B

Figure 1. The construction of the cylindrical waveguide with a current source in a cross section in a plane $z=0$

As is known (Nikolskij \& Nikolskaya, 1989), the following necessary conjugation conditions (boundary conditions) are fulfilled at the interface: the tangential component of the electric intensity $\vec{E}$ is continuous, the jump of the tangential component of magnetic intensity $\vec{H}$ is equal to the density of the surface current, 
the jump of the normal component of the electric induction $\vec{D}$ is equal to the density of the surface charge, the normal component of magnetic induction $\vec{B}$ is continuous.

We assume that the field is non-harmonically dependent on time. We search for solutions of the Maxwell equations at $z>0$ and at $z<0$ :

$$
\begin{gathered}
\nabla \times \vec{E}=-\mu \mu_{0} \frac{\partial \vec{H}}{\partial t}, \\
\nabla \times \vec{H}=\varepsilon \varepsilon_{0} \frac{\partial \vec{E}}{\partial t}
\end{gathered}
$$

on the set jumps to $\Omega$ of the tangent components of the vectors $\vec{E}$ and $\vec{H}$ :

$$
\begin{aligned}
& H_{x}^{+}(x, y, t)-H_{x}^{-}(x, y, t)=A_{x}(x, y, t), \quad(x, y) \in \Omega, t>0, \\
& H_{y}^{+}(x, y, t)-H_{y}^{-}(x, y, t)=A_{y}(x, y, t), \quad(x, y) \in \Omega, t>0, \\
& E_{x}^{+}(x, y, t)-E_{x}^{-}(x, y, t)=B_{x}(x, y, t), \quad(x, y) \in \Omega, t>0, \\
& E_{y}^{+}(x, y, t)-E_{y}^{-}(x, y, t)=B_{y}(x, y, t), \quad(x, y) \in \Omega, t>0 .
\end{aligned}
$$

Conditions (2) and (3) are slightly more general than required. In the problem of excitation of a waveguide by a source at a cross section, the jump in the tangential component of the magnetic vector is set to $M$ (this is the electric current density) and is zero at $\mathcal{N}$; the jump of the tangent component of the electric vector is everywhere zero.

The desired solutions of the Maxwell equations (1) must also satisfy the initial conditions at $t=0$ :

$$
\begin{aligned}
& H^{ \pm}(x, y, z)=0 \text { or } \frac{\partial H^{ \pm}(x, y, z)}{\partial t}=0, \\
& E^{ \pm}(x, y, z)=0 \text { or } \frac{\partial E^{ \pm}(x, y, z)}{\partial t}=0,
\end{aligned}
$$

and be sufficiently smooth at $z>0$ and at $z<0$. We assume that their limit values are correctly determined at $z \rightarrow 0 \pm 0$ in the classical or generalized sense (Pleshchinskii, 2019). 


\section{JUMP PROBLEM FOR TELEGRAPH EQUATIONS}

Let us proceed from the jump problem for the Maxwell equations (1)-(4) in the cylindrical domain $\Omega \times R$ to the jump problem for an infinite system of telegraph equations. The components of the solutions for the Maxwell equations in a cylindrical region that satisfy the boundary conditions on the wall of the waveguide (the tangent component of the electric vector is zero) can be represented for the components $H(x, y, z, t)$ in the following form (Pleshchinskii et al., 2017):

$$
\begin{gathered}
H_{z}^{ \pm}=\sum_{m} H_{z, m}^{ \pm}(z, t) \lambda_{m} \varphi_{m}(x, y), m=0,1, \ldots, \\
H_{x}^{ \pm}=\varepsilon_{0} \varepsilon \sum_{m} \frac{\partial E_{z, m}^{ \pm}}{\partial t}(z, t) \frac{\partial \psi_{m}}{\partial y}(x, y)+\sum_{m} \frac{\partial H_{z, m}^{+}}{\partial z}(z, t) \frac{\partial \varphi_{m}}{\partial x}(x, y), \\
H_{y}^{ \pm}=-\varepsilon_{0} \varepsilon \sum_{m} \frac{\partial E_{z, m}^{ \pm}}{\partial t}(z, t) \frac{\partial \psi_{m}}{\partial x}(x, y)+\sum_{m} \frac{\partial H_{z, m}^{+}}{\partial z}(z, t) \frac{\partial \varphi_{m}}{\partial y}(x, y)
\end{gathered}
$$

and for components $E(x, y, z, t)$ as follows:

$$
\begin{gathered}
E_{z}^{ \pm}=\sum_{m} E_{z, m}^{ \pm}(z, t) \chi_{m} \psi_{m}(x, y), \\
E_{\bar{x}}^{ \pm}=\sum_{m} \frac{\partial E_{z, m}^{ \pm}}{\partial z}(z, t) \frac{\partial \psi_{m}}{\partial x}(x, y)-\mu_{0} \mu \sum_{m} \frac{\partial H_{z, m}^{ \pm}}{\partial t}(z, t) \frac{\partial \varphi_{m}}{\partial y}(x, y), \\
E_{\bar{y}}^{ \pm}=\sum_{m} \frac{\partial E_{z, m}^{ \pm}}{\partial z}(z, t) \frac{\partial \psi_{m}}{\partial y}(x, y)+\mu_{0} \mu \sum_{m} \frac{\partial H_{z, m}^{ \pm}}{\partial t}(z, t) \frac{\partial \varphi_{m}}{\partial x}(x, y),
\end{gathered}
$$

where $\varepsilon$ is the dielectric constant, and $\mu$ is the magnetic permeability of the substance. The functions $\psi_{m}(x, y)$ and $\varphi_{m}(x, y)$ are orthonormal sets of eigenfunctions for the Laplace operator in the domain $\Omega$, with Neumann and Dirichlet boundary conditions, respectively. Moreover, $\lambda_{m}$ and $\chi_{m}$ are eigenvalues of the Laplace operator. We assume that a piecewise-smooth contour is such that the eigenfunctions exist in simple cases; and in simple cases, as a circle or a rectangle, they are constructed analytically, in other cases, they are constructed 
numerically. The expansion coefficients $E_{z, m}(z, t)$ and $H_{z, m}(z, t)$ are new unknown functions and must be solutions to jump problems for telegraph equations $H_{z, m}^{ \pm}(z, t)$ :

$$
\begin{gathered}
\frac{\partial^{2} H_{z, m}^{ \pm}}{\partial t^{2}}(z, t)=\frac{1}{\kappa^{2}} \frac{\partial^{2} H_{z, m}^{ \pm}}{\partial z^{2}}(z, t)-\frac{\lambda_{m}}{\kappa^{2}} H_{z, m}^{ \pm}(z, t), \quad m=0,1, \ldots \\
H_{z, m}^{+}(0, t)-H_{z, m}^{-}(0, t)=H_{0}(x, y, 0, t), \quad(x, y) \in \Omega, \\
\frac{\partial H_{z, m}^{+}}{\partial z}(0, t)-\frac{\partial H_{z, m}^{-}}{\partial z}(0, t)=H_{1}(x, y, 0, t), \quad(x, y) \in \Omega, \\
H_{z, m}^{ \pm}(z, 0)=0, \quad \frac{\partial H_{z, m}^{ \pm}}{\partial t}(z, 0)=0,
\end{gathered}
$$

and for telegraph equations $E_{z, m}^{ \pm}(z, t)$ :

$$
\begin{gathered}
\frac{\partial^{2} E_{z, m}^{ \pm}}{\partial t^{2}}(z, t)=\frac{1}{\kappa^{2}} \frac{\partial^{2} E_{z, m}^{ \pm}}{\partial z^{2}}(z, t)-\frac{\chi_{m}}{\kappa^{2}} E_{z, m}^{ \pm}(z, t), \quad m=0,1, \ldots \\
E_{z, m}^{+}(0, t)-E_{z, m}^{-}(0, t)=E_{0}(x, y, 0, t), \quad(x, y) \in \Omega, \\
\frac{\partial E_{z, m}^{+}}{\partial z}(0, t)-\frac{\partial E_{z, m}^{-}}{\partial z}(0, t)=E_{1}(x, y, 0, t), \quad(x, y) \in \Omega, \\
E_{z, m}^{+}(z, 0)=0, \quad \frac{\partial E_{z, m}^{ \pm}}{\partial t}(z, 0)=0,
\end{gathered}
$$

where $\kappa$ is the wave number $\left(\kappa^{2}=\mu_{0} \varepsilon_{0} \mu \varepsilon\right)$. The functions $H_{0}(x, y, 0, t), H_{1}(x, y, 0, t)$, $E_{0}(x, y, 0, t), E_{1}(x, y, 0, t)$ are some known functions in domains $\Omega$. We show below what these functions will be equal to. The functions are defined on $M$ as functions of the current density, and on $\mathcal{N}$ they are equal to zero.

Now we show that the desired expansion coefficients for the longitudinal field components in the problems (11)-(13) and (14)-(16) can be found after solutions for some integral equations are obtained.

For this purpose, we consider the jump problem for telegraph equation in the general case with respect to the auxiliary function $u(z, t)$ in the half-plane $t>0$ :

$$
\frac{\partial^{2} u}{\partial t^{2}}=a^{2} \frac{\partial^{2} u}{\partial z^{2}}-b^{2} u, \quad z \neq 0
$$


with boundary conditions:

$$
\begin{gathered}
u(0+0, t)-u(0-0, t)=A(t), \\
\frac{\partial u}{\partial z}(0+0, t)-\frac{\partial u}{\partial z}(0-0, t)=B(t),
\end{gathered}
$$

and initial conditions:

$$
u(z, 0)=f(z), \frac{\partial u}{\partial t}(z, 0)=F(z) .
$$

We note that the functions $f(z)$ and $F(z)$ can have discontinuities at the point $z=0$ :

$$
\begin{aligned}
& f(z)=\left\{f^{-}(z), z<0 ; f^{+}(z), z>0\right\}, \\
& F(z)=\left\{F^{-}(z), z<0 ; F^{+}(z), z>0\right\} .
\end{aligned}
$$

We seek a solution of the jump problem in the space of continuously differentiable functions. Let $F^{ \pm}(z), f^{ \pm}(z), g^{ \pm}(t), G^{ \pm}(t)$ be some known functions defined in the spaces $C^{1}(R)$ and $C^{1}\left(R^{+}\right)$.

Earlier in (16), we considered the over-determined boundary problem for telegraph equation (17) in the right quarter of the plane $(z>0, t>0)$ with initial and boundary conditions (see Figure 2):

$$
\begin{aligned}
u(z, 0)=f^{+}(z), & \frac{\partial u}{\partial t}(z, 0)=F^{+}(z), \\
u(0+0, t)=g^{+}(t), & \frac{\partial u}{\partial z}(0+0, t)=G^{+}(t) .
\end{aligned}
$$

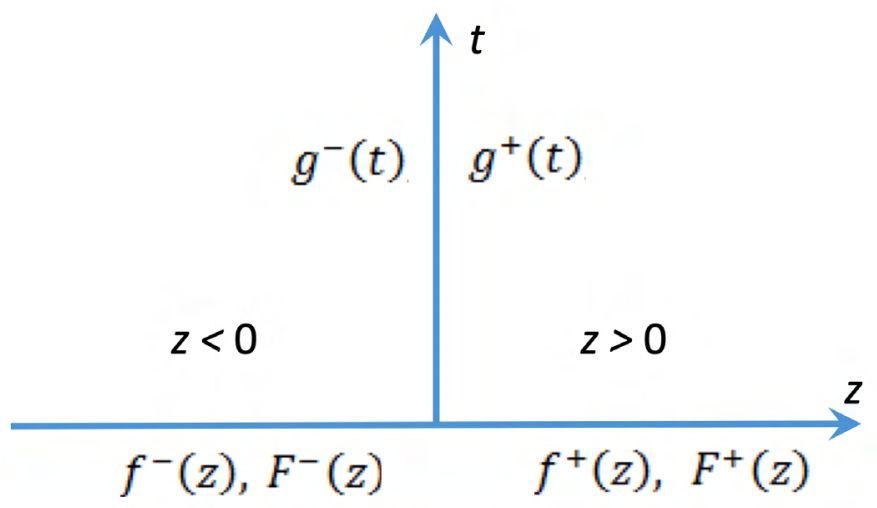

Figure 2. Traces of functions of the over-determined boundary problem for telegraph equation in the upper half-plane $\mathrm{t}>0$. 
We obtained in (16) the condition for the solvability of this problem in the following form:

$$
\frac{1}{2} f^{+}(2 a t)+\frac{1}{2} \int_{0}^{2 a t} \Phi^{+}(a t, t, \xi) d \xi=\frac{1}{2} g^{+}(2 t)+\frac{1}{2} \int_{0}^{2 t} \Psi^{+}(t, a t, \xi) d \xi
$$

or

$$
\begin{aligned}
& f^{+}(2 a t)+\frac{1}{2} \int_{0}^{2 a t}\left[\frac{1}{a} F^{+}(\xi) J_{0}\left(\frac{b}{a} \sqrt{(2 a t-\xi) \xi}\right)-b t f^{+}(\xi) \frac{J_{0}^{\prime}\left(\frac{b}{a} \sqrt{(2 a t-\xi) \xi}\right)}{\sqrt{(2 a t-\xi) \xi}}\right] d \xi \\
& =g^{+}(2 t)+\frac{1}{2} \int_{0}^{2 t}\left[a G^{+}(\xi) J_{0}(b \sqrt{(\xi-2 t) \xi})+b t g^{+}(\xi) \frac{J_{0}^{\prime}(b \sqrt{(\xi-2 t) \xi})}{\sqrt{(\xi-2 t) \xi}}\right] d \xi .
\end{aligned}
$$

Note that this equality establishes the relationship between the boundary functions in a mixed boundary problem for telegraph equation in a quarter of a plane. If the condition of solvability of the over-determined problem is executed, then it can be extended to the whole quarter-plane and even to the half-plane.

Now we consider the over-determined problem in the left quarter of the plane $(z$ $<0, t>0)$ with initial and boundary conditions

$$
\begin{aligned}
& u(z, 0)=f^{-}(z), \quad \frac{\partial u}{\partial t}(z, 0)=F^{-}(z), \\
& u(0-0, t)=g^{-}(t), \quad \frac{\partial u}{\partial z}(0-0, t)=G^{-}(t) .
\end{aligned}
$$

We replace $z$ with $\tilde{z}=-z$ and seek the function $\tilde{u}(\tilde{z}, t)=u(-z, t)$. The equation itself does not change, and the initial and boundary conditions take the form

$$
\tilde{u}(\tilde{z}, 0)=f^{-}(-\tilde{z}), \quad \frac{\partial \tilde{u}}{\partial t}(\tilde{z}, 0)=F^{-}(-\tilde{z})
$$

and

$$
\tilde{u}(0+0, t)=g^{-}(t), \quad \frac{\partial \tilde{u}}{\partial \tilde{z}}(0+0, t)=-G^{-}(t) .
$$

Then, in a similar way as in (16), we obtain the solvability condition for this problem in the following form: 


$$
\begin{aligned}
& f^{-}(-2 a t)+\frac{1}{2} \int_{0}^{2 a t}\left[\frac{1}{a} F^{-}(-\xi) J_{0}\left(\frac{b}{a} \sqrt{(2 a t-\xi) \xi}\right)-b t f^{-}(-\xi) \frac{J_{0}^{\prime}\left(\frac{b}{a} \sqrt{(2 a t-\xi) \xi}\right)}{\sqrt{(2 a t-\xi) \xi}}\right] d \xi \\
& =g^{-}(2 t)+\frac{1}{2} \int_{0}^{2 t}\left[-a G^{-}(\xi) J_{0}(b \sqrt{(\xi-2 t) \xi})+b t g^{-}(\xi) \frac{J_{0}^{\prime}(b \sqrt{(\xi-2 t) \xi})}{\sqrt{(\xi-2 t) \xi}}\right] d \xi .
\end{aligned}
$$

We use the solvability conditions and reduce solving the jump problem with zero initial conditions to solving the system of four equations:

$$
\begin{gathered}
g^{+}(\eta)+\frac{1}{2} \int_{0}^{\eta}\left[a G^{+}(\xi) J_{0}(b \sqrt{(\xi-\eta) \xi})+b t g^{+}(\xi) \frac{J_{0}^{\prime}(b \sqrt{(\xi-\eta) \xi})}{\sqrt{(\xi-\eta) \xi}}\right] d \xi=0, \\
g^{-}(\eta)+\frac{1}{2} \int_{0}^{\eta}\left[-a G^{-}(\xi) J_{0}(b \sqrt{(\xi-\eta) \xi})+b t g^{-}(\xi) \frac{J_{0}^{\prime}(b \sqrt{(\xi-\eta) \xi})}{\sqrt{(\xi-\eta) \xi}}\right] d \xi=0, \\
g^{+}(\eta)-g^{-}(\eta)=A(\eta), G^{+}(\eta)-G^{-}(\eta)=B(\eta) .
\end{gathered}
$$

We denote $\eta=2 t$. If the solvability conditions are added and subtracted, then we get two integral equations:

$$
\begin{gathered}
g^{+}(\eta)+g^{-}(\eta)+\eta \frac{b}{2} \int_{0}^{\eta}\left[g^{+}(\eta)+g^{-}(\eta)\right] \frac{J_{0}^{\prime}(b \sqrt{(\xi-\eta) \xi})}{\sqrt{(\xi-\eta) \xi}} d \xi \\
=-a \int_{0}^{\eta} B(\xi) J_{0}(b \sqrt{(\xi-\eta) \xi}) d \xi \\
a \int_{0}^{\eta}\left[G^{+}(\xi)+G^{-}(\xi)\right] J_{0}(b \sqrt{(\xi-\eta) \xi}) d \xi \\
=-A(\eta)-\eta \frac{b}{2} \int_{0}^{\eta} A(\xi) \frac{J_{0}^{\prime}(b \sqrt{(\xi-\eta) \xi})}{\sqrt{(\xi-\eta) \xi}} d \xi .
\end{gathered}
$$

If $A(\eta)=0$ and $B(\eta)$ is different from 0 , then the function $g^{+}(\eta)=g^{-}(\eta)=g(\eta)$ is found as a solution for the integral equation:

$$
2 g(\eta)+\eta b \int_{0}^{\eta} g(\xi) \frac{J_{0}^{\prime}(b \sqrt{(\xi-\eta) \xi})}{\sqrt{(\xi-\eta) \xi}} d \xi=-a \int_{0}^{\eta} B(\xi) J_{0}(b \sqrt{(\xi-\eta) \xi}) d \xi
$$


If $(\eta)=0 A(\eta) \neq 0$, then the function $G^{+}(\eta)=G^{-}(\eta)=G(\eta)$, and is found as a solution for the integral equation:

$$
2 a \int_{0}^{\eta} G(\eta) J_{0}(b \sqrt{(\xi-\eta) \xi}) d \xi=-A(\eta)-\eta \frac{b}{2} \int_{0}^{\eta} A(\xi) \frac{J_{0}^{\prime}(b \sqrt{(\xi-\eta) \xi})}{\sqrt{(\xi-\eta) \xi}} d \xi .
$$

Thus, we reduced solving the jump problem for telegraph equation to solving the Volterra integral equations (18) and (19). Solving the first equation, we can find the longitudinal components in the jump problem for $H_{z, m}(z, t)$, which corresponds to the jump problem for the equation (17) with $A(\eta)=0$ in the boundary conditions. The second equation can be used to determine $E_{z, m}(z, t)$ with $B(\eta)=0$.

\section{BOUNDARY CONDITIONS OF THE JUMP PROBLEM FOR TELEGRAPH EQUATIONS}

We express the right parts in the formulas (12) and (15) through known functions. From the conditions of the jump problem for the tangential components of the electric and magnetic vectors (2), (3), we obtain the conjugation conditions for the normal components of these vectors. We express the terms of the left-hand sides under conjugation conditions through $E_{z, m}(z, t)$ and $H_{z, m}(z, t)$. For this, we use the representations of the transverse field components in formulas (6), (7), (9), (10) $H_{x}(x, y, z, t), H_{y}(x, y, z, t), E_{x}(x, y, z, t), E_{y}(x, y, z, t)$, we substitute them into the corresponding conditions (2), (3) and for any $(x, y) \in \Omega$ we get:

$$
\begin{gathered}
\varepsilon_{0} \varepsilon \sum_{m}\left[\frac{\partial E_{z, m}^{+}}{\partial t}(0, t)-\frac{\partial E_{z, m}^{-}}{\partial t}(0, t)\right] \frac{\partial \psi_{m}}{\partial y}(x, y) \\
+\sum_{m}\left[\frac{\partial H_{z, m}^{+}}{\partial z}(0, t)-\frac{\partial H_{z, m}^{-}}{\partial z}(0, t)\right] \frac{\partial \varphi_{m}}{\partial x}(x, y)=A_{x}(x, y, t), \\
-\varepsilon_{0} \varepsilon \sum_{m}\left[\frac{\partial E_{z, m}^{+}}{\partial t}(0, t)-\frac{\partial E_{z, m}^{-}}{\partial t}(0, t)\right] \frac{\partial \psi_{m}}{\partial x}(x, y) \\
+\sum_{m}\left[\frac{\partial H_{z, m}^{+}}{\partial z}(0, t)-\frac{\partial H_{z, m}^{-}}{\partial z}(0, t)\right] \frac{\partial \varphi_{m}}{\partial y}(x, y)=A_{y}(x, y, t),
\end{gathered}
$$




$$
\begin{gathered}
\sum_{m}\left[\frac{\partial E_{z, m}^{+}}{\partial z}(0, t)-\frac{\partial E_{z, m}^{-}}{\partial z}(0, t)\right] \frac{\partial \psi_{m}}{\partial y}(x, y)-\mu_{0} \mu \sum_{m}\left[\frac{\partial H_{z, m}^{+}}{\partial t}(0, t)\right. \\
\left.-\frac{\partial H_{z, m}^{-}}{\partial t}(0, t)\right] \frac{\partial \varphi_{m}}{\partial y}(x, y)=B_{x}(x, y, t), \\
\sum_{m}\left[\frac{\partial E_{z, m}^{+}}{\partial z}(0, t)-\frac{\partial E_{z, m}^{-}}{\partial z}(0, t)\right] \frac{\partial \psi_{m}}{\partial y}(x, y) \\
+\mu_{0} \mu \sum_{m}\left[\frac{\partial H_{z, m}^{+}}{\partial t}(0, t)-\frac{\partial H_{z, m}^{-}}{\partial t}(0, t)\right] \frac{\partial \varphi_{m}}{\partial x}(x, y)=B_{y}(x, y, t) .
\end{gathered}
$$

In the system (20), we differentiate the first equation with respect to $x$, the second with respect to $y$ and add them. Then we get:

$$
\begin{gathered}
\sum_{m}\left[\frac{\partial H_{z, m}^{+}}{\partial z}(0, t)-\frac{\partial H_{z, m}^{-}}{\partial z}(0, t)\right]\left[\frac{\partial^{2} \varphi_{m}}{\partial x^{2}}(x, y)+\frac{\partial^{2} \varphi_{m}}{\partial y^{2}}(x, y)\right] \\
=\frac{\partial A_{x}}{\partial x}(x, y, t)+\frac{\partial A_{y}}{\partial y}(x, y, t) .
\end{gathered}
$$

Now let us differentiate the first equation with respect to $y$, the second one with respect to $x$, and we subtract the second equation from the first equation. Then we obtain:

$$
\begin{gathered}
\varepsilon_{0} \varepsilon \sum_{m}\left[\frac{\partial E_{z, m}^{+}}{\partial t}(0, t)-\frac{\partial E_{z, m}^{-}}{\partial t}(0, t)\right]\left[\frac{\partial^{2} \psi_{m}}{\partial x^{2}}(x, y)+\frac{\partial^{2} \psi_{m}}{\partial y^{2}}(x, y)\right] \\
=\frac{\partial A_{x}}{\partial y}(x, y, t)-\frac{\partial A_{y}}{\partial x}(x, y, t) .
\end{gathered}
$$

We perform similar transformations in the system (21) and obtain the following equations:

$$
\begin{gathered}
\sum_{m}\left[\frac{\partial E_{z, m}^{+}}{\partial z}(0, t)-\frac{\partial E_{z, m}^{-}}{\partial z}(0, t)\right]\left[\frac{\partial^{2} \psi_{m}}{\partial x^{2}}(x, y)+\frac{\partial^{2} \psi_{m}}{\partial y^{2}}(x, y)\right] \\
=\frac{\partial B_{x}}{\partial x}(x, y, t)+\frac{\partial B_{y}}{\partial y}(x, y, t), \\
-\mu_{0} \mu \sum_{m}\left[\frac{\partial H_{z, m}^{+}}{\partial t}(0, t)-\frac{\partial H_{z, m}^{-}}{\partial t}(0, t)\right]\left[\frac{\partial^{2} \varphi_{m}}{\partial x^{2}}(x, y)+\frac{\partial^{2} \varphi_{m}}{\partial y^{2}}(x, y)\right] \\
=\frac{\partial B_{x}}{\partial y}(x, y, t)-\frac{\partial B_{y}}{\partial x}(x, y, t) .
\end{gathered}
$$


In square brackets, the expressions for the sum of the derivatives of the functions $\phi_{m}(x, y)$ and $\psi_{m}(x, y)$ represent the Laplace operator applied to these functions, respectively. We use this property of the eigenfunctions. Next, we scalar multiply both sides of the equations on $\phi_{k}(x, y)$ and $\psi_{k}(x, y)$, and, using the orthogonality of these functions, we obtain:

$$
\begin{gathered}
{\left[\frac{\partial H_{z, k}^{+}}{\partial z}(0, t)-\frac{\partial H_{z, k}^{-}}{\partial z}(0, t)\right] \lambda_{k}} \\
=-\iint_{\Omega}\left[\frac{\partial A_{x}}{\partial x}(x, y, t)+\frac{\partial A_{y}}{\partial y}(x, y, t)\right] \varphi_{k}(x, y) d x d y, \\
\lambda_{k} \mu_{0} \mu\left[\frac{\partial H_{z, k}^{+}}{\partial t}(0, t)-\frac{\partial H_{z, k}^{-}}{\partial t}(0, t)\right] \\
=\iint_{\Omega}\left[\frac{\partial B_{x}}{\partial y}(x, y, t)-\frac{\partial B_{y}}{\partial x}(x, y, t)\right] \varphi_{k}(x, y) d x d y, \\
=-\iint_{\Omega}\left[\frac{\partial B_{x}}{\partial x}(x, y, t)+\frac{\partial B_{y}}{\partial y}(x, y, t)\right] \psi_{k}(x, y) d x d y, \\
\varepsilon_{0} \varepsilon\left[\frac{\partial E_{z, k}^{+}}{\partial t}(0, t)-\frac{\partial E_{z, k}^{-}}{\partial t}(0, t)\right] \chi_{k} \\
=-\iint_{\Omega}\left[\frac{\partial A_{x}}{\partial y}(x, y, t)-\frac{\partial A_{y}}{\partial x}(x, y, t)\right] \psi_{k}(x, y) d x d y .
\end{gathered}
$$

We express the time derivatives in the systems of equations (22) and (23) as follows:

$$
\begin{gathered}
\int_{\tau}\left[\frac{\partial H_{z, k}^{+}}{\partial t}(0, t)-\frac{\partial H_{z, k}^{-}}{\partial t}(0, t)\right] d \tau \\
=\frac{1}{\lambda_{k} \mu_{0} \mu} \iint_{\tau} \int_{\Omega}\left[\frac{\partial B_{x}}{\partial y}(x, y, t)-\frac{\partial B_{y}}{\partial x}(x, y, t)\right] \varphi_{k}(x, y) d x d y d \tau, \\
\int\left[\frac{\partial E_{z, k}^{+}}{\partial t}(0, t)-\frac{\partial E_{z, k}^{-}}{\partial t}(0, t)\right] d \tau \\
=-\frac{1}{\varepsilon_{0} \varepsilon \chi_{k}} \iiint_{\tau}\left[\frac{\partial A_{x}}{\partial y}(x, y, t)-\frac{\partial A_{y}}{\partial x}(x, y, t)\right] \psi_{k}(x, y) d x d y d \tau .
\end{gathered}
$$

We consider that the initial conditions are zero, and we get: 


$$
\begin{gathered}
H_{z, k}^{+}(0, t)-H_{z, k}^{-}(0, t) \\
=\frac{1}{\lambda_{k} \mu_{0} \mu} \int_{\tau} \iint_{\Omega}\left[\frac{\partial B_{x}}{\partial y}(x, y, t)-\frac{\partial B_{y}}{\partial x}(x, y, t)\right] \varphi_{k}(x, y) d x d y d \tau, \\
E_{z, k}^{+}(0, t)-E_{z, k}^{-}(0, t)=-\frac{1}{\varepsilon_{0} \varepsilon \chi_{k}} \iiint_{\tau}\left[\frac{\partial A_{x}}{\partial y}(x, y, t)-\frac{\partial A_{y}}{\partial x}(x, y, t)\right] \psi_{k}(x, y) d x d y d \tau .
\end{gathered}
$$

The last two expressions and the first equations in the systems of equations (22), (23) are the conjugation conditions on the waveguide cross section in the jump problem for $H_{z, m}(z, t)$ and $E_{z, m}(z, t)$, respectively.

We use the obtained results and write down the jump problem for telegraph equation with respect to $H_{z, m}(z, t)$. We assume that $A_{x}(x, y, t)=j_{x}(x, y, t)$ and $A_{y}(x, y$, $t)=j_{y}(x, y, t), B_{x}(x, y, t)=0$ and $B_{y}(x, y, t)=0$. Then we get:

$$
\begin{gathered}
\frac{\partial^{2} H_{z, k}^{ \pm}}{\partial t^{2}}(z, t)=\frac{1}{\kappa^{2}} \frac{\partial^{2} H_{z, k}^{ \pm}}{\partial z^{2}}(z, t)-\frac{\lambda_{k}}{\kappa^{2}} H_{z, k}^{ \pm}(z, t), \\
H_{z, k}^{+}(0, t)-H_{z, k}^{-}(0, t)=0, \\
\frac{\partial H_{z, k}^{+}}{\partial z}(0, t)-\frac{\partial H_{z, k}^{-}}{\partial z}(0, t) \\
=-\frac{1}{\lambda_{k}} \iint_{\Omega}\left[\frac{\partial j_{x}}{\partial x}(x, y, t)+\frac{\partial j_{y}}{\partial y}(x, y, t)\right] \varphi_{k}(x, y) d x d y, \quad(x, y) \in M .
\end{gathered}
$$

Since the first condition is homogeneous, we denote $H_{z, k}^{+}(0, t)=H_{z, k}^{-}(0, t)=H_{z, k}(t)$ , and then the new desired function is the solution for the Volterra integral equation of the second kind (for the function $g(h)$ by the formula (18)

$$
\begin{gathered}
2 H_{z, k}(t)+b t \int_{0}^{t} H_{z, k}(\xi) \frac{J_{0}^{\prime}(b \sqrt{(\xi-t) \xi})}{\sqrt{(\xi-t) \xi}} d \xi \\
=\frac{a}{\lambda_{k}} \int_{0}^{t} J_{0}\left(b \sqrt{(\xi-t) \xi)} \iint_{M}\left[\frac{\partial j_{x}}{\partial x}(x, y, \xi)+\frac{\partial j_{y}}{\partial y}(x, y, \xi)\right] \varphi_{k}(x, y) d x d y d \xi,\right.
\end{gathered}
$$

where $a=1 / \kappa, b=\sqrt{\lambda_{k}} / \kappa$.

After calculating the trace of the function $H_{z, k}(t)$ on the waveguide cross section, solving the jump problem is reduced to the recovery of two functions $H_{z, k}^{-}(z, t)$ and $H_{z, k}^{+}(z, t)$ by the following formulas from [16]: 


$$
\begin{aligned}
& H_{z, k}^{-}(z, t)=H_{z, k}(t+z / a)+b \frac{z}{a} \int_{0}^{t+z / a} H_{z, k}(\xi) \frac{J_{0}^{\prime}\left(b \sqrt{(\xi-t)^{2}-z^{2} / a^{2}}\right)}{\sqrt{(\xi-t)^{2}-z^{2} / a^{2}}} d \xi, \\
& H_{z, k}^{+}(z, t)=H_{z, k}(t-z / a)-b \frac{z}{a} \int_{0}^{t-z / a} H_{z, k}(\xi) \frac{J_{0}^{\prime}\left(b \sqrt{(\xi-t)^{2}-z^{2} / a^{2}}\right)}{\sqrt{(\xi-t)^{2}-z^{2} / a^{2}}} d \xi .
\end{aligned}
$$

The jump problem for $E_{z, m}(z, t)$ takes the following form:

$$
\begin{gathered}
\frac{\partial^{2} E_{z, k}^{ \pm}}{\partial t^{2}}(z, t)=\frac{1}{\kappa^{2}} \frac{\partial^{2} E_{z, k}^{ \pm}}{\partial z^{2}}(z, t)-\frac{\chi_{k}}{\kappa^{2}} E_{z, k}^{ \pm}(z, t), \\
E_{z, k}^{+}(0, t)-E_{z, k}^{-}(0, t) \\
=-\frac{1}{\varepsilon_{0} \varepsilon \chi_{k}} \iint_{\tau} \iint_{\Omega}\left[\frac{\partial A_{x}}{\partial y}(x, y, t)-\frac{\partial A_{y}}{\partial x}(x, y, t)\right] \psi_{k}(x, y) d x d y d \tau, \\
\frac{\partial E_{z, k}^{+}}{\partial z}(0, t)-\frac{\partial E_{z, k}^{-}}{\partial z}(0, t)=0 .
\end{gathered}
$$

In this problem, we have a homogeneous second condition, then $\frac{\partial E_{z, k}^{+}}{\partial z}(0, t)=\frac{\partial E_{z, k}^{-}}{\partial z}(0, t)=\frac{\partial E_{z, k}}{\partial z}(0, t)$ and the limit value of the function $\frac{\partial E_{z, k}}{\partial z}(0, t)$ on the cross section of the waveguide we find as a solution for the Volterra integral equation of the first kind by formula (19):

$$
\begin{gathered}
2 a \int_{0}^{t} \frac{\partial E_{z, k}}{\partial z}(0, \xi) J_{0}(b \sqrt{(\xi-t) \xi}) d \xi \\
=\frac{1}{\varepsilon_{0} \varepsilon \chi_{k}} \int_{0}^{t} \iint_{M}\left[\frac{\partial j_{x}}{\partial y}(x, y, \tau)-\frac{\partial j_{y}}{\partial x}(x, y, \tau)\right] \psi_{k}(x, y) d x d y d \tau \\
+\frac{b}{2} \frac{t}{\varepsilon_{0} \varepsilon \chi_{k}} \int_{0}^{t} \frac{J_{0}^{\prime}(b \sqrt{(\xi-t) \xi})}{b \sqrt{(\xi-t) \xi}} \\
\times \int_{0}^{t} \iint_{M}\left[\frac{\partial j_{x}}{\partial y}(x, y, \tau)-\frac{\partial j_{y}}{\partial x}(x, y, \tau)\right] \psi_{k}(x, y) d x d y d \tau d \xi .
\end{gathered}
$$

The values of the functions $E_{z, k}^{+}(z, t)$ and $E_{z, k}^{-}(z, t)$ in the entire waveguide are determined by the following two formulas from [16]: 


$$
\begin{aligned}
& E_{z, k}^{+}(z, t)=-a \int_{0}^{t-z / a} \frac{\partial E_{z, k}}{\partial z}(0, \xi) J_{0}\left(b \sqrt{(\xi-t)^{2}-z^{2} / a^{2}}\right) d \xi, \\
& E_{z, k}^{-}(z, t)=a \int_{0}^{t-z / a} \frac{\partial E_{z, k}}{\partial z}(0, \xi) J_{0}\left(b \sqrt{(\xi-t)^{2}-z^{2} / a^{2}}\right) d \xi .
\end{aligned}
$$

Thus, all components of the electromagnetic field can be expressed through solutions for the Volterra equations (24) and (25).

\section{CONCLUSIONS}

The problem of the excitation of a cylindrical waveguide by the surface currents on infinitely thin metal plate located in the cross section is considered. The components of the excited electromagnetic field in the waveguide are searched in the form of series in the eigenfunctions of the Laplace operator. The jump problem for searching the unknown coefficients of these series is reduced to solving a system of the Volterra integral equations.

\section{ACKNOWLEDGEMENTS}

The work is performed according to the Russian Government Program of Competitive Growth of Kazan Federal University.

\section{REFERENCES}

Barybin, A. A. (2007). Electrodynamics of the waveguide structures. Theory of excitation and wave connection, Moscow: Fizmatlit. [In Russian]

Bogolyubov, A. N., Delitsyn, A. L., \& Sveshnikov, A. G. (2003). Excitation of Waveguides with a Nonhomogeneous Filling. Computational Mathematics and Modeling, 14(1), 64-73. doi: https://doi.org/10.1023/A:1022029918613 
Collin, R. E. (1960). Field theory of guided waves. New York: John Wiley \& Sons, Inc. Retrieved from https://es.scribd.com/doc/183903942/FieldTheory-of-Guided-Waves-Collin-pdf

Eslami, R., \& Ahmadi, S. (2019). Investigating the Role of Educational Media on Secondary School Students' Learning Process Improvement in Jahrom City. Fournal of Humanities Insights, 3(01), 13-6. doi: https:/ / doi.org/10.22034/ jhi.2019.80890

Ghaderi, M. A. \& Mahdavi Panah, M. (2018). Studying The Importance And Application Of The "Tradition" Viewpoint In The Islamic Law Based On The Viewpoint Of Imam Khomeini (RA) In The Book Of "Tahrir OlWasilla". UCT Journal of Social Sciences and Humanities Research, 6(1), 6-8.

Islamov, A. E., Rassolov, I. M., Petunova, S. A., Albov, A. P., Zaikina, I. V., \& Shulga, T. I. (2017). Students' Tolerant Behavior Formation Mechanisms. International Electronic Fournal of Mathematics Education, 12(1), 43-50. Retrieved from https://www.iejme.com/article/students-tolerant-behavior-formationmechanisms

Jabbari, E., Charbaghi, Z., \& Dana A. (2019). Investigating the Effects of Educational and Motivational Education at Different Levels on the Performance and Application of dart throwing. Fournal of Humanities Insights, 3(02), 37-44. doi: https://doi.org/10.22034/jhi.2019.80896

Kashisaz, S., \& Mobaraki, E. (2018). The Effects of Private Education Institutes in Providing Modern Financial Knowledge in Developing Countries. Fournal of Humanities Insights, 02(04), 172-178. doi: https://doi.org/10.22034/ jhi.2018.80887

Kheirabadi, M. A., \& Mirzaei, Z. (2019). Descriptive valuation pattern in education and training system: a mixed study. Fournal of Humanities Insights, 3(01), 7-12. doi: https://doi.org/10.22034/jhi.2019.80889

Kong, J. A. (2002). Electromagnetic Wave Theory. EMW Publishing. 
Mittra, R. (1971). Analytical techniques in the theory of guided waves. Macmillan.

Nakhaee, J., \& Nasrabadi, M. A. (2019). Strategies for Research-Centered Education of Architectural Designing by Examining the Research-Centered Activities of the Top Universities. Fournal of Humanities Insights, 3(02), 50-56. doi: https://doi.org/10.22034/jhi.2019.80898

Nikolskij, V. V., \& Nikolskaya, T. I. (1989). Electrodynamics and propagation of radiowaves, Moscow, Nauka. [In Russian]

Pan, W., \& Li, K. (2013). Propagation of SLF/ELF electromagnetic waves. Springer Science \& Business Media.

Pleshchinskii, N. B. (2019). On Generalized Solutions of Problems of Electromagnetic Wave Diffraction by Screens in the Closed Cylindrical Waveguides. Lobacherskii Fournal of Mathematics, 40(2), 201-209. doi: https:// doi.org/10.1134/S1995080219020124

Pleshchinskii, N. B., Markina, A. G., \& Tumakov, D. N. (2017). On Waveguide Excitation By Source Placed On The Lateral Cross-Section. Revista Publicando, 4(13(2)), 351-364. Retrieved from https://revistapublicando.org/ revista/index.php/crv/article/view/891

Sadiku, M. N. (2014). Elements of electromagnetics. Oxford university press.

Sailaukyzy, A., Shakuova, R., Sak, K., \& Lebedeva, T. (2018). Contemporary view to the history of Kazakhstan's democratic journalism and publicism. Opción, 34(85-2), 774-799.

Samarskii, A. A., \& Tikhonov, A. N. (1947). On the excitation of the radiowaveguides. Zhurnal Tekhnicheskoi Fiziki, 17(11), 1283. [In Russian]

Samarskii, A. A., \& Tikhonov, A. N. (1948). The representation of the field in waveguide in the form of the sum of TE and TM modes. Zhurnal Tekhnicheskoi Fiziki, 18, 971-985. [In Russian] 
Shapochkin, P. Y., Kapitonov, Y. V., Poltavtsev, S. V., Lozhkin, M. S., Lozhkina, O. A., Manukhova, A. D., ... \& Solov'ev, I. A. (2017). A theory of excitation of a planar semiconductor optical waveguide using a diffraction grating: Single-scattering approximation. Optics and Spectroscopy, 122(2), 303314. doi: https://doi.org/10.1134/S0030400X17020254

Solncev, V. A. (2009). Theory of excitation of the wavegides. Applied Nonlinear Dynamics, 17(3), 55-89.

Sun, T., \& Wu, D. (2010). Guided-mode resonance excitation on multimode planar periodic waveguide. Fournal of Applied Physics, 108(6). doi: https://doi. org/10.1063/1.3483958

Yirmiyahu, Y., Niv, A., Biener, G., Kleiner, V., \& Hasman, E. (2007). Excitation of a single hollow waveguide mode using inhomogeneous anisotropic subwavelength structures. Optics express, 15(20), 13404-13414. doi: https://doi.org/10.1364/OE.15.013404 


$$
\text { /8/ }
$$




\title{
THE INTEGRATION OF PEDAGOGICAL TECHNOLOGIES AS A CONDITION FOR IMPROVING THE QUALITY OF EDUCATION
}

\author{
Elzara V. Gafiyatova \\ Kazan Federal University, Kazan, Russia. \\ Dina Z. Gaynutdinova \\ Kazan Federal University, Kazan, Russia.
}

Albina T. Galiakhmetova

Kazan State Power Engineering University, Russia.

Viktoriya Levchenko

Samara National Research University, Russia.

E-mail: alta261@rambler.ru

Recepción: 05/08/2019 Aceptación: 09/09/2019 Publicación: 23/10/2019

\section{Citación sugerida:}

Gafiyatova, E.V., Gaynutdinova, D.Z., Galiakhmetova, A.T. y Levchenko, V. (2019). The integration of pedagogical technologies as a condition for improving the quality of education. 3C TIC. Cuadernos de desarrollo aplicados a las TIC. Edición Especial, Octubre 2019, 126-139. doi: https://doi.org/10.17993/3ctic.2019.83-2.126-139

Suggested citation:

Gafiyatova, E.V., Gaynutdinova, D.Z., Galiakhmetova, A.T. \& Levchenko, V. (2019). The integration of pedagogical technologies as a condition for improving the quality of education. 3C TIC. Cuadernos de desarrollo aplicados a las TIC. Special Issue, October 2019, 126-139. doi: https://doi.org/10.17993/3ctic.2019.83-2.126-139 


\section{ABSTRACT}

The article presents the results of a study of the activities of educational institutions to solve an actual problem - the problem of improving the quality of education. One of the promising ways to improve the quality of education in educational institutions is the integration of pedagogical technologies. The aim of the study is the development and theoretical substantiation of the system of integration of pedagogical technologies, the advantage of which is the sum of the advantages of the constituent technologies and focused on improving the quality of education. The model of flexible integrated technology of project-module training is proposed as an example. The developed models of flexible integral pedagogical technologies were experimentally tested and widely tested in the activities of Kazan Federal University, Kazan State Power Engineering University, Samara National Research University and several schools in Kazan (Republic of Tatarstan). This approbation led to the conclusion about the effectiveness of these models. The results of the study indicate the positive impact of these models on the main parameters characterizing the effectiveness and quality of the pedagogical process in the education system. The study confirmed that one of the important ways to increase the efficiency of the pedagogical process in education is the integration of pedagogical technologies, the implementation of flexible integrated pedagogical technologies capable adapt to different levels of complexity of pedagogical conditions and effectively solve modern problems of education. The integration of pedagogical technologies, the implementation of flexible pedagogical technologies in education allows not only to improve the quality, but also the efficiency of education, ensures the operational regulation of pedagogical technologies and the conditions of the educational process, considering the type and theme of the academic discipline, the level of students' development, availability of material resources, tasks of education.

\section{KEYWORDS}

Pedagogical technology, Integration, Improving the quality of education, Flexible technology of project-modular training. 


\section{INTRODUCTION}

The current stage of human civilization development imposes rather high requirements for their professional competence. The effectiveness of the pedagogical process in some educational organizations remains low. Some teachers use traditional methods that are not adapted to the existing conditions of the educational process. Some scientific and pedagogical workers own innovative pedagogical technologies that solve only several educational tasks. Some teachers do not have innovative technologies that comprehensively and effectively solve modern pedagogical tasks as indicated by many researchers (Polat, 2007; Yefimova, 2017; Kozma, 2003; Ahmed, 2012; Kuzmina et al., 2018; Kuzmina et al., 2018; Solnyshkina et al., 2014; Kheirabadi \& Mirzaei, 2019; Kashisaz \& Mobarak, 2018; Nakhaee \& Nasrabadi, 2019; Jasur \& Nilufar, 2018).

Due to the low efficiency of the pedagogical technologies implemented by teachers, the quality of education remains low. This is evidenced by the level of the final and intermediate results of the work of some educational organizations.

One of the important ways to improve the efficiency of the pedagogical process in the education system is the integration of pedagogical technologies, implementation of flexible integrated pedagogical technologies which can adapt to different levels of pedagogical conditions and effectively solve modern educational problems (Grudtsina et al., 2017; Kasteyeva, 2018; Eslami \& Ahmadi, 2019; Jabbari et al., 2019).

Thus, the scientific novelty of the research is determined by the fact that it was the first at the didactic level to develop a model for the integration of pedagogical technologies, to identify goals, objectives, principles, and conceptual foundations of innovative integrated technology. Also for the first time, a model and concept of an integrated technology of project-module training in a general education and universities were developed. 


\section{MATERIALS AND METHODS}

The experience in implementing integrated learning technologies is described in the works of Vyacheslav Guzeev (1999), "System bases of integrated educational technology" and Mouratt Choshanov (1996), "Theory and technology of problem-module training in a vocational school".

Currently, the concept of "technology" is interpreted in different ways. We understand "pedagogical technology" as a holistic pedagogical system focused on the effective achievement of educational and educational tasks and presented in the form of goals, objectives, conceptual foundations, principles, features of building the content, methods and algorithm of organizing the pedagogical process.

The most common educational technologies currently are:

- Project training.

- Technology of student-centered learning.

- Modular training.

- Information technology.

Each of these pedagogical technologies provides an increase in the efficiency of the pedagogical process based on the realization of any achievement of pedagogy. The flexible integrated technology, in turn, includes all the best technologies comprising it, provides a practical orientation of training, activates independent work, motivation of students, implementing differentiation and individualization of learning, provides an opportunity to form students' individual learning paths and development. In general, under the integration of educational technologies, we understand the process and the result of the union of educational technology in some integrity, followed by sealing connections between its components. The result of this association is an innovative technology (integral). 
The connection between pedagogical technologies is determined by the general main goals of education, as well as by a wide range of tasks solved (Galiakhmetova, 2016; Gabitov et al., 2017; Solnyshkina et al., 2016).

After analyzing technologies of project, modular training and information technology, we found it possible to integrate them into a new technology - a flexible technology of project-module training and to determine the goals, objectives, principles and conceptual foundations of this technology.

Currently, the implementation of almost all pedagogical technologies requires computer tools, modern information technologies (Kabirova et al., 2018). In this regard, the term "computer learning" in the name of innovative integrated technology is not necessary to endure. Therefore, we will designate an innovative integrated technology as a flexible integrated technology of project-modular training.

The objectives of the flexible integrated technology of project-module training:

1) The development of the individual cognitive abilities of the student.

2) Effective training based on a scientifically developed program.

3) The formation of skills to work with information, the development of communication skills (Solnyshkina et al., 2014; Yakupov et al., 2018).

4) To form the student's maximum educational information (as much as he can learn).

5) The formation of research skills, the ability to make optimal decisions.

The main conceptual provisions of the technology of project-modular and computer training:

Individual, personality-oriented independent educational and cognitive activity of students with the assistance of a teacher. 
Awareness of the learning problem by the students and an orientation towards the achievement of significant educational goals and the final practical result.

The essence of project-modular and computer-based education is that a student, independently or relatively independently, can work on an educational project based on an individual program of actions offered to him, bank of information, and methodological guidance for achieving the set of educational goals and the final practical product. In this case, teacher's functions can vary from informationcontrolling to advisory-coordinating.

The key goal of the project-modular and computer-based learning technology is to improve the quality and effectiveness of the learning process based on:

a) Development of creative thinking, abilities to work with information, development of universal educational actions.

b) The formation of research skills.

c) The development of individual cognitive abilities.

d) Implementation of computer tools.

Principles of project-modular and computer-based training:

1) Modularity (considered as a principle of the system approach, development, dynamism and lability of the system functioning). Relying on the principle of modularity in the learning process contributes to the development of knowledge mobility and technology flexibility.

The implementation of this principle allows:

Integrate and differentiate the content of training based on the systematization and differentiation of project modules of educational material, ensuring the development of the course (subject) in full, abbreviated and in-depth versions. 
Make an independent choice of a student of the course the appropriate option depending on the level of training, development, and provide individual pace of the work program.

Reduce the training course without prejudice to depth of learning material.

Strengthen the advisory and coordinating functions of the teacher on the students' independent cognitive activity.

2) Problem making principle - the principle provides for the creation of special situations of intellectual difficulties, problem situations and their solutions in the process of learning. Creation and analysis of the problem is the initial stage of the algorithm of the considered technology. This stage ensures the activation of students 'mental activity, the use of non-standard approaches to solving problems, the development of students' creative and critical thinking.

The formation of criticality in the process of project-module training is carried out based on purposeful creation of special situations - situations for finding errors.

3) «Compression» of educational information. This principle is based on the main directions of the theory of educational information compression:

a) The theory of didactic units' integration (Erdniyev, 1986).

b) The theory of meaningful generalization.

c) The concept of knowledge engineering.

Orientation to the final practical product - the principle means that the goals in the project-module training should not only be certain knowledge, skills, competencies that must be formed among the students. The main purpose of training based on this innovative technology should be:

a) The creation (preparation) of the final practical "tangible" product (for example, in the form of a school museum, conference, video, book, sports or literary festival). 
b) Development of a project (model, construct) of the final product (for example, development of a museum project, conference program, sports or literary festival, etc.).

In this context, the final educational goals in relation to the goal (as the final practical product) are only a means of their realization. The logic of the educational process here is: "in order to develop, create a final product (conference, video, literary celebration, etc.) it is necessary for students to master certain knowledge, abilities, skills". This principle involves the stimulation of students learning activities and motivation rise.

4) Computerization of training - the principle of using computer tools in training. Thus, it can be concluded that the project-modular and computer-based training technology is built on the integration of the "efforts" of five factors: problem making, modular, "information compression", orientation to the final product, computerization of training.

The efficiency of project-modular training technology is also improved through the implementation of additional principles that derive from the previous four principles.

Additional principles of project-modular training technology:

1. Adaptability (flexibility) or control of the educational process (at any time a teacher can correct the educational process). This principle is an addition to the modularity principle.

2. Motivation (stimulation) of educational and cognitive activity (the principle follows from the principle of orientation to the final practical product).

Flexibility of integrated technology can be defined as the ability to respond quickly and adapt to changing pedagogical conditions. 


\section{RESULTS AND DISCUSSION}

The developed models of flexible integral pedagogical technologies were experimentally tested and widely tested in the activities of Kazan Federal University, Kazan State Power Engineering University, Samara National Research University and several schools in Kazan (Republic of Tatarstan). This approbation led to the conclusion about the effectiveness of these models. The results of the study indicate the positive impact of these models on the main parameters characterizing the effectiveness and quality of the pedagogical process in the education system.

So, there is a positive trend in the experimental groups of universities:

A) The results in training (the number of students who passed the exam on good and excellent marks increased from $51.2 \%$ to $71.6 \%$ ).

B) The quality of the educational process (the number of studies in which the students' independent activity was activated increased from $41 \%$ to $81 \%$ ).

C) The level of teachers' creative self-realization (the number of teachers with a high level of creative self-realization increased from $34 \%$ to $62 \%$ ).

\section{SUMMARY}

The study confirmed that one of the important ways to increase the efficiency of the pedagogical process in education is the integration of pedagogical technologies, the implementation of flexible integrated pedagogical technologies capable adapt to different levels of complexity of pedagogical conditions and effectively solve modern problems of education.

The integration of pedagogical technologies, the implementation of flexible pedagogical technologies in schools and universities allows not only to improve the quality, but also the efficiency of education, ensures the operational regulation of 
pedagogical technologies and the conditions of the educational process in schools and universities, considering the type and theme of the academic discipline, the level of students' material resources, tasks of education.

Thus, we were able to justify the conceptual conditions of the study, consisting of the fact that:

- Integration of pedagogical technologies is an important condition for improving the efficiency and quality of the pedagogical process.

- Design and implementation of managed (flexible) integrated educational technologies to create a mechanism of stable and continuous development of self-managed educational institution.

\section{CONCLUSION}

The study made it possible to summarize that the actualization of the practice of improving the quality of education based on the integration of pedagogical technologies is caused by the objective trend of the modernization of education. This fact necessitated the mastering of pedagogical workers by the newest pedagogical methods and ideas of modern pedagogy, in mastering the mechanisms of replacing the existing separate scattered pedagogical technologies with complete systems of effective flexible pedagogical technologies. These systems combine the achievements of existing technologies and provide solutions to the key tasks of modern education.

\section{ACKNOWLEDGEMENTS}

The work is performed according to the Russian Government Program of Competitive Growth of Kazan Federal University. 


\section{BIBLIOGRAPHY}

Ahmed, P. S. (2012). The way we teach, the way they learn. Procedia-Social and Behavioral Sciences, 47, 1554-1557. doi: https://doi.org/10.1016/j. sbspro.2012.06.860

Choshanov, M. A. (1996). Flexible technology problem-modular training. Moskva: Education.

Erdniyev, P. M. (1986). Integration of Didactic Units in Mathematics Education.

Eslami, R., \& Ahmadi, S. (2019). Investigating the Role of Educational Media on Secondary School Students' Learning Process Improvement in Jahrom City. Fournal of Humanities Insights, 3(01), 13-6. doi: https://doi.org/10.22034/ jhi.2019.80890

Gabitov, A., Solnyshkina, M., Shayakhmetova, L., Ilyasova, L., \& Akbarova, S. (2017). Text Complexity In Russian Textbooks On Social Studies. Revista Publicando, 4(13(1)), 597-606.

Galiakhmetova, A. T. (2016). Flexible Integrated Technology of PersonalityModular and Computer Training as a Means of Improving the Quality of Education in University. Vestnik VEGU, 5(85), 32-40.

Grudtsina, L. Y., Filippova, A. V., Makarova, E. V., Kondratyuk, D. L., Usanov, V. E., \& Molchanov, S. V. (2017). Preventive Pedagogy: Methods of Research University Students' Readiness Formation for a Healthy Lifestyle. International Electronic Fournal of Mathematics Education, 12(1), 51-58. Retrieved from: https://www.iejme.com/article/preventive-pedagogy-methods-ofresearch-university-students-readiness-formation-for-a-healthy

Guzeyev, V. V. (1999). System bases of integrated educational technology ... dokt.ped.nauk. - Moskva. 
Jabbari, E., Gharbaghi, Z., \& Dana A. (2019). Investigating the Effects of Educational and Motivational Education at Different Levels on the Performance and Application of dart throwing. Fournal of Humanities Insights, 3(02), 37-44. doi: https://doi.org/10.22034/jhi.2019.80896

Jasur, I., \& Nilufar, A. (2018). Personal names spell-checking - a study related to Uzbek. UCT Journal of Social Sciences and Humanities Research, 6(1), 1-6.

Kabirova, A. A., Fatkhullova, K. S., Denmukhametova, E. N., \& Kulmanov, K. S. (2018). Educational Internet Resources in Turkic Languages. HELIX, 8(1), 2469-2472. Retrieved from http://helix.dnares. in/2018/02/01/educational-internet-resources-in-turkic-languages/

Kashisaz, S., \& Mobaraki, E. (2018). The Effects of Private Education Institutes in Providing Modern Financial Knowledge in Developing Countries. Fournal of Humanities Insights, 02(04), 172-178. doi: https://doi.org/10.22034/ jhi.2018.80887

Kasteyeva, M. (2018). Belgium priority as a partner for the Republic of Kazakhstan. Opción, 34(85-2), 752-772.

Kheirabadi, M. A., \& Mirzaei, Z. (2019). Descriptive valuation pattern in education and training system: a mixed study. Fournal of Humanities Insights, 3(01), 7-12. doi: https://doi.org/10.22034/jhi.2019.80889

Kozma, R. B. (2003). Technology and classroom practices: An international study. Fournal of research on technology in education, 36(1), 1-14. doi: https://doi.or g/10.1080/15391523.2003.10782399

Kuzmina, E. K., Nazarova, G. I., Nizamieva, L. R., Leblanc, G. (2018). Innovative Technologies of Teaching Business French. International fournal of Engineering \& Technology, 7(4.7), 85-87. Retrieved from https://www. sciencepubco.com/index.php/ijet/article/view/20390/9555 
Kuzmina, E. K., Vassilieva, V. N., Valeeva, A. F., \& Porshneva, E. R. (2018). " Techno-R" Technology in Teaching the Students of Linguistic Direction the Latin Language. HELIX, 8(1), 2178-2181. Retrieved from http://helix.dnares.in/wp-content/uploads/2018/02/2178-2181.852.pdf

Nakhaee, J., \& Nasrabadi, M. A. (2019). Strategies for Research-Centered Education of Architectural Designing by Examining the Research-Centered Activities of the Top Universities. Fournal of Humanities Insights, 3(02), 50-56. doi: https://doi.org/10.22034/jhi.2019.80898

Polat, E. S. (2007). Modern Pedagogical Technologies in Education. uchebnoe posobie. - Moskva, izdat. centr "Akademiya".

Solnyshkina, M. I., Harkova, E. V., \& Kiselnikov, A. S. (2014). Unified (Russian) State Exam in English: Reading Comprehension Tasks. English Language Teaching, 7(12), 1-11. doi: https://doi.org/10.5539/elt.v7n12p1

Solnyshkina, M. I., Ismagilova, A. R., \& Hajrullina, A. I. (2014). SGEM2014 Conference on Psychology and Psychiatry, Sociology and Healthcare, Education. SGEM2014 Conference Proceedings, 3, 295-302.

Solnyshkina, M. I., Solovova, E. N., Harkova, E. V., \& Kiselnikov, A. S. (2016). Language Assessment Course: Structure, Delivery and Learning Outcomes. International journal of environmental and science education, 11(6), 12231229. doi: https://doi.org/10.12973/ijese.2016.392a

Yakupov, R. N., Fatkhullova, K. S., Denmukhametova, E. N., \& Kulmanov, K. S. (2018). The Foreign Students' Communicative Competence Development in the Tatar Language. HELIX, $8(1), 2182-2185$. Retrieved from http://www.helix.dnares.in/wp-content/uploads/2017/12/2182-2185.853. pdf

Yefimova, S. A. (2017). Problems of Competence-oriented Screening of Applied Qualifications. Obrazovaniye i nauka, 19(5), 120-137. 


\section{/9/}




\section{FORMATION OF SENIOR STUDENTS' SOCIOCULTURAL COMPETENCE BY MEANS OFBLOG TECHNOLOGY}

Luiza R. Zakirova

Kazan (Volga Region) Federal University, Russia.

Marianna E. Yashina

Kazan (Volga Region) Federal University, Russia.

Mariya B. Kazachkova

Moscow State Institute of International Relations (University), Russia.

E-mail: clivia29@yandex.ru

Recepción: 05/08/2019 Aceptación: 09/09/2019 Publicación: 23/10/2019

\section{Citación sugerida:}

Zakirova, L.R., Yashina, M.E. y Kazachkova, M.B. (2019). Formation of senior students' sociocultural competence by means of blog technology. 3C TIC. Cuadernos de desarrollo aplicados a las TIC. Edición Especial, Octubre 2019, 140-151. doi: https://doi. org/10.17993/3ctic.2019.83-2.140-151

\section{Suggested citation:}

Zakirova, L.R., Yashina, M.E. \& Kazachkova, M.B. (2019). Formation of senior students' sociocultural competence by means of blog technology. 3C TIC. Cuadernos de desarrollo aplicados a las TIC. Special Issue, October 2019, 140-151. doi: https://doi. org/10.17993/3ctic.2019.83-2.140-151 


\section{ABSTRACT}

This article is devoted to the research of the formation of sociocultural competence in the process of teaching a foreign language at the senior stage with the help of the blog technology. The relevance of this article is because sociocultural competence is one of the structural components of communicative competence, which is key in the context of global intercultural communication. The aim of the research is to provide the theoretical basis and practical verification of the effectiveness of using blog technology in the formation of the sociocultural competence of senior students in a foreign language class. In the research, the authors analysed the characteristics of the blog and the benefits of its use, revealed that using the blog technology can develop almost all types of speech activities: writing, reading and listening, as well as improve the sociocultural competence of students. Obviously, the blog technology has many advantages compared to other technologies, as it includes all types of information. Consequently, the blog provides an opportunity to implement various tasks. The article describes the experimental work, namely, its purpose, tasks, stages, conditions, content, methods of teaching the formation of the sociocultural competence of senior students.

\section{KEYWORDS}

Foreign language, Socio-cultural competence, Intercultural interaction, Blog, Information technologies. 


\section{INTRODUCTION}

In the period of globalization, the study of a foreign language becomes a necessity for integration in the modern world. The high degree of mobility of people around the world leads to intercultural interaction. In this regard, according to the new educational standards of June 5, 2012, each graduate of the Russian school is obliged to master at a certain level at least one foreign language. However, language learning includes many aspects, one of which is sociocultural. Direct communication with native speakers requires competence not only in matters of grammar and phonetics of a foreign language, but also in the field of foreign culture, traditions and customs. The significance of the sociocultural component is often underestimated, although it is precisely it, in our opinion, that can contribute to the transformation of the English language into a subject-specific discipline in Russian secondary schools.

The peculiarity of a foreign language functioning is that its communicative function provides intercultural communication. The interdisciplinary nature of the content of the subject "foreign language" has favourable opportunities for creating a wide sociocultural educational space, while using the sociocultural approach in language education that gives a new, deeper and more meaningful discovery of all components of the concept of functional sociocultural literacy. Socio-cultural competence can be achieved at the expense of other disciplines, and such sources of sociocultural information as literature, mass media, the Internet, and films and can be an essential addition to the development of sociocultural competence.

The knowledge of the native speakers' culture provides with a deeper mutual understanding. The main thing in the process of learning is not only the accumulation of information about the country, but also the knowledge of people, their peers, the way of thinking, behaviour, and attitude to human values.

We can say that culture and intercultural communication problems should be presented in educational process as global education objectives. However, the new concept of sociocultural education requires serious didactic thinking, choice 
of approach to learning a foreign language which can provide socialization of training foreign language communication and connection of communicative activity of students with cognitive research to the study of sociocultural portrait of native speakers (Rakhimova, 2017; Kheirabadi \& Mirzaei, 2019; Nakhaee \& Nasrabadi, 2019; Alipichev et al., 2017).

We tried to analyse a theoretical basis and practical verification of the effectiveness of using blog technology in the formation of the sociocultural competence of senior students at the lessons of a foreign language. While analysing the term "sociocultural competence" we resorted to educational literature on the research topic; theoretically and experimentally substantiated the effectiveness of the use of blog technology in the formation of the sociocultural competence of senior students; developed educational and methodical recommendations on the formation of the sociocultural competence of senior students based on the Google Blogger service (Kashisaz \& Mobarak, 2018; Eslami \& Ahmadi, 2019; Jabbari et al., 2019).

The theoretical basis of this work was the scientific works of Russian and foreign methodologists on the formation of sociocultural competence in foreign language lessons such as Bim (2003), Bayram (1997), Galskova (2000), Sysoev (2004), Shakiba \& Delqandi (2018).

According to Sut (2003), sociocultural competence can be defined as the students' ability to accomplish proper cross-cultural communication, whereas Nikitenko (2005) wrote that sociocultural competence is represented in the knowledge of the language (non-equivalent and normal vocabulary), knowledge of national culture, and the norms of behaviour.

It is worth mentioning that modern methodological research is based on the linguistic approach of teaching a foreign language. At the same time, vocabulary with a cross-cultural component, cross-cultural information, affecting the most diverse aspects of the life of the country of the studied language, its history, literature, science, art, as well as traditions, customs and customs, are highlighted. 
The linguistic and cultural aspect contributes to the enrichment of the subjectcontent plan. Its more thorough selection and earlier use of a foreign language in school is one of the reserves for increasing its activity.

Culture in its various directions contributes to the formation of a person's personality. "Foreign Language Culture" is the issue that can provide students with the process of mastering a foreign language in the educational, cognitive, developmental and educational aspects.

The elements that make up the content of a "foreign language culture" are the following:

1) A set of knowledge about the language being studied, about the functions of the language in society, about the culture of the country of the language being studied, about the ways of most effectively mastering the language as a means of communication, about the possibilities of the influence of the learning process on the students' personality, and all this is called the conditional element - knowledge;

2) Experience in the implementation of speech and learning activities - learning and speech skills;

3) The ability to perform all the speech functions necessary to meet their needs and the needs of society;

4) The experience of an emotional attitude to the process of mastering a foreign language culture to the teacher and students as speech partners, to the language being studied as an academic subject, to the role of language in the life of society - an experience turned to the system of personal values or otherwise - motivation.

Mastering a foreign language as a means of intercultural communication is impossible without knowledge of the socio-cultural and sociolinguistic characteristics of the target language country (Ostroumova et al., 2014; Sailaukyzy et al., 2018). Using cross-cultural information in the learning process increases 
students' cognitive activity, examines their communicative abilities, favors their communication skills and abilities, as well as positive motivation, provides an incentive for independent work on the language and contributes to solving educational tasks.

The main purpose of teaching a foreign language in the secondary school is to develop the personality of the pupil in close connection with the teaching of the culture of the country of a foreign language contributing to the desire to participate in intercultural communication and independently improve in the classroom activities.

\section{METHODS}

In the course of the research we used the following methods: analysis of scientific and methodological literature on the research problem, scientific observation, generalization of the results of the experimental work. The relationships between theoretical stance, pedagogical context and research approach.

\section{RESULTS AND DISCUSSION}

In the process of the research, we analysed the methodological literature of Russian and foreign authors on the formation of sociocultural competence at the senior stage in secondary school. Sociocultural competence is one of the structural components of communicative competence, which is key in the context of global intercultural communication. Thus, the formation of "sociocultural competence" in a secondary school is usually understood to mean familiarizing students with the realities of the country/countries of the language being studied, their culture and customs within certain themes and situations of communication necessary for the successful implementation of intercultural communication. In accordance with the Federal State Educational Standard of Secondary General Education (GEF SOO) for 10-11 grades dated October 6, 2009, clause 9.1.2, students must acquire communicative competence in the subject "Foreign 
Language" (basic level) in order to successfully socialize and fulfill themselves, and also use a foreign language as a "tool of intercultural communication in the modern multicultural world". In addition, according to the GEF SOO, students should acquire knowledge about the countries of the language being studied, considering its socio-cultural component. One of the requirements for the "portrait of a high school student" is also "the ability to build one's speech and nonverbal behaviour adequately to this specificity; the ability to single out what is common and different in the culture of one's native country and the country / countries of the language being studied".

Communicative competence is the main purpose of teaching a foreign language at school, but it includes several subcompetences, such as sociocultural and sociolinguistic, which should be included in the ZUN (knowledge, skills) of a graduate of a secondary school in the Russian Federation.

It is not possible to implement the formation of communicative competence without knowledge from the field of linguistic studies, since each foreign word is a product of a foreign language culture and reflects the internal structure of the language.

\section{SUMMARY}

To increase the efficiency of shaping sociocultural competence among schoolchildren, we suggested using the blog technology Web 2.0. The term "weblog" or "blog" was first used by Jorn Barger in 1997. Blogs have become widely used since 2001 and are now widespread. The first blog was an annotated list of bookmarks, open to the general public.

IT-technologies set new trends in different spheres including education and pedagogy. Teaching English as a foreign language and education in general is a huge ground for development (Gatiyatullina et al., 2018). 
In the process of the research we analysed the characteristic features of the blog and the benefits of using blog technology. Moreover, we found out that with the help of blog technology it is possible to develop almost all types of speech activity: writing, reading and listening, as well as improving the sociocultural competence of students. Obviously, the blog technology has many advantages compared to other technologies, as it brings together all types of information. Consequently, the blog provides an opportunity to implement the tasks of a different plan.

The research is aimed at the practical study of the problem of the formation of sociocultural competence in a comprehensive school. The main goal of any scientific research is to improve the educational process, so the experiment is one of the main research methods. In this regard, in order to test the effectiveness of the use of blog technology, we carried out experimental work in which 30 senior students participated. The practical part of the experimental work was carried out based on the Municipal Public Educational Institution "Secondary School N. ${ }^{\circ}$ " of the city of Leninogorsk. The main goal of our experimental work is the approbation of an educational and methodological complex that contributes to the effective formation of the sociocultural competence of senior students.

In the course of the experiment, an educational Internet blog was developed and tested, aimed at improving the formation of the sociocultural competence of senior students. The lessons in the control group were carried out in accordance with the program, in the traditional question-answer form. The educational process in the experimental group, in turn, was also carried out in accordance with the program requirements, but in an unconventional form (using the educational web blog).

\section{CONCLUSIONS}

The control slice of students' knowledge, as well as the results of the comparative characteristics of the successful implementation of tasks of the experimental group at the ascertaining and final stages showed the following: 
1) The level of sociocultural competence in the experimental group is higher than in the control group.

2) The level of formation of sociocultural competence in the experimental group at the final stage is much higher than at the ascertaining stage.

The results obtained allowed us to talk about the effectiveness of the use of the educational blog we developed in English lessons in order to increase the sociocultural competence of senior students.

In the course of this scientific study, we concluded that the Internet resources created by native speakers and teachers of the English language make it possible to improve the efficiency of teaching a foreign language. Besides, students learn to transfer already available knowledge of a foreign language to new sociocultural situations and problems, to see contradictions, having at the same time independence of judgements (Rachimova et al., 2016). Moreover, they get the opportunity to perceive the natural form of the language, which corresponds to the realities of the English-speaking countries, while increasing their competence in linguistic and social and cultural aspects.

\section{ACKNOWLEDGEMENTS}

The work is performed according to the Russian Government Program of Competitive Growth of Kazan Federal University.

\section{REFERENCES}

Alipichev, A. Y., Khalevina, S. N., Trubcheninova, A. A., \& Fedulova, A. N. (2017). Practical Solutions to Foreign Language Training Courses Implemented Using Distance Learning Tools. International Electronic Fournal of Mathematics Education, 12(1), 59-68. Retrieved from https://www.iejme.com/ article/practical-solutions-to-foreign-language-training-courses-implementedusing-distance-learning-tools 
Bim, I. L. (2003). Ways to improve the professional competence of a foreign language teacher, Methodical mosaic application. Foreign languages in school, 1, 86.

Byram, M. (1997). Teaching and assessing intercultural communicative competence. Multilingual Matters.

Eslami, R., \& Ahmadi, S. (2019). Investigating the Role of Educational Media on Secondary School Students' Learning Process Improvement in Jahrom City. Fournal of Humanities Insights, 3(01), 13-6. doi: https://doi.org/10.22034/ jhi.2019.80890

Galskova, N. D. (2000). Modern Methods of Teaching a Foreign Language. Moscow: Arkti-Glossa, 265.

Gatiyatullina, G. M., Kiselnikov, A. S., Tarasova, F. K., Sungatullina, D. D., \& Gafiyatova, E. (2018). Text Complexity Modification By Means Of ItTechnologies. Modern Fournal of Language teaching Methods, 8(10), 396-401.

Jabbari, E., Charbaghi, Z., \& Dana A. (2019). Investigating the Effects of Educational and Motivational Education at Different Levels on the Performance and Application of dart throwing. Fournal of Humanities Insights, 3(02), 37-44. doi: https://doi.org/10.22034/jhi.2019.80896

Kashisaz, S., \& Mobaraki, E. (2018). The Effects of Private Education Institutes in Providing Modern Financial Knowledge in Developing Countries. Journal of Humanities Insights, 02(04), 172-178. doi: https://doi.org/10.22034/ jhi.2018.80887

Kheirabadi, M. A., \& Mirzaei, Z. (2019). Descriptive valuation pattern in education and training system: a mixed study. Fournal of Humanities Insights, 3(01), 7-12. doi: https://doi.org/10.22034/jhi.2019.80889 
Nakhaee, J., \& Nasrabadi, M. A. (2019). Strategies for ResearchCentered Education of Architectural Designing by Examining the ResearchCentered Activities of the Top Universities. Fournal of Humanities Insights, 3(02), 50-56. Retrieved from http://www.jhumanities.net/article_80898_ dcaa625489b5f0ff63aea1583a374ee8.pdf

Nikitenko, Z. I. (2005). The Problem of Teaching a Cultural Component in the Content of Education in primary school. Foreign languages, 3, 13-17.

Ostroumova, O. F., Nizamieva, L. R., \& Nazarova, G. I. (2014). The didactic aspect of foreign language creative teaching. Fournal of language and literature, 5(3), 76-82. doi: https://doi.org/10.7813/jll.2014/5-3/14

Rachimova, A. E., Varlamova, E. V., \& Tulusina, E. A. (2016). Advantages of computer technologies use in training in foreign languages at the present stage of an education system modernization. Modern Fournal of Language Teaching Methods, Special Issue (December), 97.

Rakhimova, A. E. (2017). Sociocultural competence as one of the core competencies of the individual. Espacios, 38(45), 34. Retrieved from https:// www.revistaespacios.com/a17v38n45/a17v38n45p34.pdf

Sailaukyzy, A., Shakuova, R., Sak, K., \& Lebedeva, T. (2018). Contemporary view to the history of Kazakhstan's democratic journalism and publicism. Opción, 34(85-2), 774-799.

Shakiba, A., \& Delqandi, B. (2018). A review on Form A visual test of Torrance creativity test in Iran. UCT Journal of Social Sciences and Humanities Research, 6(2), 6-19.

Sut, U. J. (2003). The opportunities of the usage of the Internet as a means of development of students' sociocultural competence in teaching English. Foreign languages, 2, 31-36.

Sysoev, P. V. (2004). Cultural determination in the system of multicultural education. Foreign languages, 4, 14-20. 


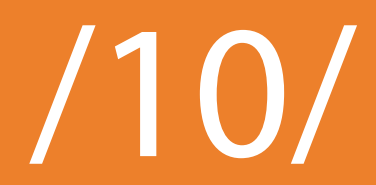




\section{IMPROVEMENT OF STUDENTS CRITICAL THINKING THROUGH THE USING OF THE METHOD OF CASE STUDIES}

Darya Sergeevna Zaudalova

Kazan Federal University, Kazan, Russia.

Svetlana Vladimirovna Karkina Kazan Federal University, Kazan, Russia.

Singh Balwant

PhD Partap College of Education, India, Ludhiana

E-mail:s.karkina@mail.ru

Recepción: 05/08/2019 Aceptación: 09/09/2019 Publicación: 23/10/2019

\section{Gitación sugerida:}

Zaudalova, D.S., Karkina, S.V. y Balwant, S. (2019). Improvement of students critical thinking through the using of the method of case studies. 3C TIC. Cuadernos de desarrollo aplicados a las TIC. Edición Especial, Octubre 2019, 152-163. doi: https://doi. org/10.17993/3ctic.2019.83-2.152-163

\section{Suggested citation:}

Zaudalova, D.S., Karkina, S.V. \& Balwant, S. (2019). Improvement of students critical thinking through the using of the method of case studies. 3C TIC. Cuadernos de desarrollo aplicados a las TIC. Special Issue, October 2019, 152-163. doi: https://doi. org/10.17993/3ctic.2019.83-2.152-163 


\section{ABSTRACT}

The conditions of modernization of modern reality require the introduction of new teaching methods that consider the subjective needs of the individual and provide for anybody with the opportunity to build an individual trajectory of development. The development of critical thinking among students in the modern education system is one of the important directions in the development of moral, comprehensively developed personality. In addition to the fact that critical thinking is metasubject and can be applied in all spheres of life, it is necessary to optimize the work of students in different subjects of the educational program. The study used method of case study that is one of the very perspective instruments for the improvement of the educational theory and practice. Case study is a method that uses description of situation from real educational practice and life at all. Working with each situation allows you to develop the ability to analyze, draw conclusions, evaluate and interpret. Cases contain not only information about the situation, but also additional sources of information, such as illustrations or criteria for their evaluation. We have developed a technique for the development of critical thinking in the process of creating illustrations for literary works in the technique of linocut. Within the framework of this technique, nine cases have been developed. The study concluded that the advantage of cases is the ability to optimally combine theory and practice. The method of cases contributes to the development of the ability to analyze, interpret, draw conclusions on a specific situation and evaluate, choose the best option and plan its implementation, which can significantly improve the efficiency of critical thinking in students.

\section{KEYWORDS}

Critical thinking, Case studies, High education, Student, Personal development. 


\section{INTRODUCTION}

The conditions of modernization of modern reality require the introduction of new teaching methods that consider the subjective needs of the individual and provide for anybody with the opportunity to build an individual trajectory of development. The free development of the individual is relevant on a global scale and characterizes the main trends in the development of world consciousness. According to literature research "The problem of free will, one of the most serious ones for the Western civilization as a whole" (Smyslova \& Khabibullina, 2016). Some of modern researchers such as Nurgayanova, Ahmetova and Batyrshina (2015) highlight the importance of intercultural interaction in the process of personal development (Kheirabadi \& Mirzaei, 2019; Borisova et al., 2017). The educational possibilities of ethno-confessional environment were studied by Faizrakhmanova and Kovrikova (2017) (Kashisaz \& Mobarak, 2018). The importance in this context is the task of education an "individual capable of artistic and creative re-comprehension and the development of the surrounding world in accordance with the laws of beauty" (Akhmetshina \& Kadyjrova, 2017). Such researchers as Valeeva, Karkina and Starčič (2018) study the ways for activization of individual capable by the using of personal-oriented approach, when other researchers like Butenko and Khodos (2002) state as most important trend the improvement of critical thinking.

The development of critical thinking among students in the modern education system is one of the important directions in the development of moral, comprehensively developed personality. Critical thinking is necessary to optimize the work of students in different subjects of the educational program (Murasheva et al, 2018; Eslami \& Ahmadi, 2019; Jabbari et al., 2019; Ogar et al., 2018).

In Cottrell's work (2017) critical thinking is defined as comparison of arguments and proofs for and against. Also, in her work, she refers to the definition of E. Glazer. He says that "critical thinking implies constant attempts to examine any beliefs or knowledge in the light of the testimonies that support them and the conclusions they reach". 
The author of the definition also emphasizes the importance of three aspects of critical thinking: constancy - careful consideration of the issue and return to it, proof - evaluation of the evidence put forward in favor of the proposal or point of view, consequence - reflection on what may lead to the assumption or point of view, what conclusions can be drawn, whether they are applicable, rational, and if not, whether the original assumptions or points of view should be revised.

Dianov (2014) in his work refers to two definitions. One highlights critical thinking as the ability to analyze information from the standpoint of logic, the ability to make informed judgments, decisions and apply the results to both standard and non-standard situations, issues and problems. The second belongs to Canadian Professor R. Johnson. He states that critical thinking is a special kind of mental activity that allows a person to make a sound judgment about the proposed point of view or model of behavior.

Also Dianov (2014) refers to the works of R. Paul, one of the leading experts of the United States in the field of theory and practice of critical thinking, who says that "critical thinking is thinking about thinking, that is, when a person thinks in order to improve thinking".

\section{METHODS}

The study used method of case study that is one of the very perspective instruments for the improvement of the educational theory and practice. Case study is a method that uses description of situation from real educational practice and life at all. According to the instruction students should research the situation, the meaning of the problem, offer possible ways for decision and chose the best from them (Vinevskaya, 2015; Nakhaee \& Nasrabadi, 2019). Cases are based on the real facts or very close to the real life conditions. Currently, in connection with the modernization of Russian education in the systems of secondary and higher education in Russia is the introduction of the case-method as one of the new and effective methods of training. 


\section{RESULTS AND DISCUSSION}

Critical thinking, like informal logic, views knowledge as a property of the whole community, not just of the individual. Questions and criticism determine the strategy of reasoning analysis. With their help, there is an improvement and expansion of the original knowledge, and not the creation of self-evident knowledge on a clear, reliable Foundation. Critical thinking focuses on the analysis of "natural" reasoning, not trying to fit them under the standard structure of formal logic. Procedures of reasoning, as already noted, are analyzed in the "anthropological" context, considering the characteristics of the reasoning subject, which is characterized by a certain will, objectives, educational and professional level.

Critical thinking is focused on "participation" in the social and individual life of a person: reasoning is applied not only in the scientific sphere, but also in other areas of human activity, including the sphere of his everyday life. Within the framework of critical thinking, we study "how a person thinks", making decisions, planning his / her life activity and implementing his / her practical plans. One of the tasks of critical thinking is to influence the level of "practical rationality" of society, including those who make decisions and those who implement them.

Currently, the case-method is actively implemented in the practice of the educational process in Russia. The case study introduces students to a specific real situation, designed to analyze different types of information, its generalization, problem formulation skills and the development of possible solutions in accordance with the established criteria. A distinctive feature of the case-method is the independent activity of students, during which there is the assimilation of knowledge and the formation of skills, as a result of which there is a creative mastery of professional skills and the development of mental abilities.

Educational cases can be based on several types of research:

1. An explanatory study in which an explanation of a case or phenomenon occurs. 
2. The pilot case study is a preliminary study. Its purpose is to prove the need for further study of the problem.

3. Collective research - the study of information about several ready-made studies, the use of the results and experience of past work.

4. The instrumental study refers to a specific case to get an idea of the phenomenon.

5. Descriptive study - a study which introduces the problem, "enters in" (Gaur et al., 2019).

Among the variety of techniques of fine arts we have chosen linocut. This is a technique of printing graphics, is an engraving on linoleum or similar polymerplastic materials. It belongs to the group of high-print engravings.

According to certain features of its performance, linocut is characterized by limited opportunities for students by transferring the image only with black paint and paper color. In the absence of students' experience in this technique of printed graphics, the transfer of realistic images in this technique is impossible, which allows students to focus on both graphic means of expression (stroke, spot), and to enhance their ability to stylize the image, through critical analysis.

We have developed a technique for the development of critical thinking in the process of creating illustrations for literary works in the technique of linocut. Within the framework of this technique, nine cases have been developed. Working with each situation allows you to develop the ability to analyze, draw conclusions, evaluate and interpret. Cases contain not only information about the situation, but also additional sources of information, such as illustrations or criteria for their evaluation. Work with each case can be both group and individual. 
The cases developed by us consist of 4 blocks and include:

- Situation (Block 1) - this block contains the problem situation with which students will work. The situation is brief, describes a specific example. The theme of the situation is artistic creativity, illustration. The described situation does not have a title or a brief description, with the main idea of the text highlighted. The text of this block also provides links to annexes (block 4), which can be accessed by students in order to better understand the situation.

- Questions (Block 2) - this block includes several questions, the answers to which help to understand the problems of the situation from block 1. Search for answers to questions allows you to better identify the topic of the problem situation, better navigate in its structure. Each of the questions is subject to a single goal of development of critical thinking and allows you to develop the ability to analyze, the ability to interpret, the ability to make a conclusion and the ability to assess. When working with this block, students can also access applications from block 4 if the task requires it.

- Practical task (Block 3) - within this block, students perform a creative practical task presented in each of the cases with its own conditions and rules. The purpose of this block is to summarize the data obtained in the course of working with the problem situation and consolidate the skills of analysis, interpretation, conclusion and evaluation in practice. If this is required by the practice assignment, students can also access the applications in block 4 .

- Applications (Block 4) - this block includes data that helps to solve issues and problem situations while working with other blocks from the case (blocks $1,2,3)$. The appeal to the applications is a variable part, but it will significantly increase the probability of the correct execution of tasks from the case and will allow you to better develop the skills of critical thinking. The information provided in the appendices are reproductions of works by artists and memos to consolidate oral knowledge in the field of illustration and artistic creativity. 
Topics of developed cases:

- Illustration as an art form

- Composition as an illustration

- How to work with composition

- Graphic as a mean of expression

- What is stylization
- Stylization by means of graphic expressive means

- Introduction to linocut

- Sketch for linocut

- The illustration in the technique of linocut

\section{SUMMARY}

The application of the case-method is a complex and structured process in which a significant role is played by the levels of preparedness of the teacher and students to the activities within the case-method.

The case-method promotes the development of critical thinking and motivates students to study a specific topic in detail. This method also helps students stimulate conversation between student and teacher. This is the most active method of learning, allowing the best way to reveal the talent of students. Many teachers use the case-method to improve the ability to learn. This teaching method is an alternative to the class-lesson system of education in the classroom. The casemethod is a powerful tool that connects the learning environment and the real world.

\section{CONCLUSIONS}

The development of critical thinking is an important part of the process of personal development of students in the classroom of fine arts. The process of creating an art object requires not only the possession of techniques of performing art works, but also a special way of thinking that allows you to analyze works of art, to justify and formulate conclusions about the harmonious composition of the image. The chosen case-method is best suited for the development of critical thinking. 
Features of its structure allow to work out the basic mechanisms of critical thinking - analysis, formulation of conclusions, evaluation and interpretation of the results. Mastering the technique of linocut requires the conditions for the development of students' critical analysis skills necessary in the process of image stylization. Features of performance in this technique limit the artistic methods of image transmission, which contributes to the activation of critical analysis processes in students.

The case-method can be used in different areas of educational activity and for different ages, so it is a promising pedagogical technique for further study.

\section{ACKNOWLEDGEMENTS}

The work is performed according to the Russian Government Program of Competitive Growth of Kazan Federal University.

\section{REFERENCES}

Akhmetshina, E. G., \& Kadyjrova, L. H. (2017). Pedagogical approaches to the development system of artistic culture of individual. Revista san gregorio, (20), 188-193. Retrieved from https://dialnet.unirioja.es/servlet/ articulo? codigo $=6236963$

Borisova, O. V., Vasbieva, D. G., Malykh, N. I., Vasnev, S. A., \& Vasneva, N. N. (2017). Trends and Challenges in Development of Continuing Vocational Education and Training in Russia. International Electronic Journal of Mathematics Education, 12(1), 69-78. Retrieved from https://www.iejme.com/ article/trends-and-challenges-in-development-of-continuing-vocationaleducation-and-training-in-russia

Butenko, A. V., \& Khodos, E. A. (2002). Critical thinking: Method, theory, practice. 
Cottrell, S. (2017). Critical thinking skills: Effective analysis, argument and reflection. Macmillan International Higher Education.

Dianov, A. (2014). Mozg: populyarnaya entziklopedia. Eksmo, 224 p.

Eslami, R., \& Ahmadi, S. (2019). Investigating the Role of Educational Media on Secondary School Students' Learning Process Improvement in Jahrom City. Fournal of Humanities Insights, 3(01), 13-16. doi: https:// doi.org/10.22034/ jhi.2019.80890

Faizrakhmanova, L. T., \& Kovrikova, E. V. (2017). The Ethno-Confessional Relations in the Context of Culture and Education (Kazan province, XVIII-beginning of XX century). Bylye Gody, 43(1), 30-39. doi: https://doi. org/10.13187/bg.2017.1.30

Gaur, D., Bhatia,J., \& Priya, A. (2019). Case Study: A Contemporary Teaching Technique`s Permeation into Real Life. Professionalism in Education. CoConstructiong Professional Knowledge: Learning Across Disciplines. Second Edition 2019. Global Printing Services, New Delhi, 222 - 226.

Jabbari, E., Charbaghi, Z., \& Dana A. (2019). Investigating the Effects of Educational and Motivational Education at Different Levels on the Performance and Application of dart throwing. Fournal of Humanities Insights, 3(02), 37-44. doi: https://doi.org/10.22034/jhi.2019.80896

Kashisaz, S., \& Mobaraki, E. (2018). The Effects of Private Education Institutes in Providing Modern Financial Knowledge in Developing Countries. Journal of Humanities Insights, 02(04), 172-178.

Kheirabadi, M. A., \& Mirzaei, Z. (2019). Descriptive valuation pattern in education and training system: a mixed study. Fournal of Humanities Insights, 3(01), 7-12. doi: https://doi.org/10.22034/jhi.2019.80889 
Murasheva, A. A., Stolyarov, V. M., Lomakin, G. V., Lepekhin, P. A., \& Tarbaev, V. A. (2018). Evaluate the use of farmlands encumbered with electric grid facilities: damage factors and solution approaches. Opción, 34(852), 677-705.

Nakhaee, J., \& Nasrabadi, M. A. (2019). Strategies for Research-Centered Education of Architectural Designing by Examining the Research-Centered Activities of the Top Universities. Fournal of Humanities Insights, 3(02), 50-56. doi: https://doi.org/10.22034/jhi.2019.80898

Nurgayanova, N., Ahmetova, L., \& Batyrshina, G. (2015). Intercultural interaction of the Volga Region nations in the context of ethnomusical traditions. Biosciences Biotechnology Research Asia, 12(3). doi: http://dx.doi. org/10.13005/bbra/ 1963

Ogar, J. N., Ogar, T. E., \& Bassey, S. A. (2018). Ambivalence Human Nature and Social Justice. UCT Journal of Social Sciences and Humanities Research, 6(2), 20-25.

Smyslova, E. V., \& Khabibullina, L. F. (2016). The problem of Free Will in "The Clockwork Testament or: Enderby's End" by A. Burgess. The Turkish Online Journal of Design, Art and Communication. - Turkey, TOFDAC.

Valeeva, R. A., Karkina, S. V., \& Starčič, A. I. (2018, October). Distance Learning for Aesthetic Education-Informed Professional Development and Life-Long Learning of Student Teachers. In Proceedings of the Sixth International Conference on Technological Ecosystems for Enhancing Multiculturality (pp. 597-603). ACM. doi: https://doi.org/10.1145/3284179.3284283

Vinevskaya, A. V. (2015). Case method in pedagogic: practicum for teachers and students. Rostov na Donu: Pheniks, 141 p. 


$$
\text { /11/ }
$$




\section{PROJECT ACTIVITY AS A MEANS OF IMPROVING THE QUALITY OF PROFESSIONAL TRAINING OF FUTURE PHILOLOGISTS}

Guzel A. Izmaylova

Kazan Federal University, Kazan, Russia.

Leilya R. Mukhametzyanova

Kazan Federal University, Kazan, Russia.

Natalia V. Konopleva

Kazan Federal University, Kazan, Russia.

Natalia V. Gorbunova

V.I. Vernadsky Crimean Federal University

E-mail: guzel.gulyusa@mail.ru

Recepción: 05/08/2019 Aceptación: 09/09/2019 Publicación: 23/10/2019

\section{Gitación sugerida:}

Izmaylova, G.A., Mukhametzyanova, L.R., Konopleva, N.V. y Gorbunova, N.V. (2019). Project activity as a means of improving the quality of professional training of future philologists. 3C TIC. Cuadernos de desarrollo aplicados a las TIC. Edición Especial, Octubre 2019, 164-179. doi: https://doi.org/10.17993/3ctic.2019.83-2.164-179

\section{Suggested citation:}

Izmaylova, G.A., Mukhametzyanova, L.R., Konopleva, N.V. \& Gorbunova, N.V. (2019). Project activity as a means of improving the quality of professional training of future philologists. 3C TIC. Cuadernos de desarrollo aplicados a las TIC. Special Issue, October 2019, 164-179. doi: https://doi.org/10.17993/3ctic.2019.83-2.164-179 


\section{ABSTRACT}

In the context of modernization of education and digitalization of society, one of the socially significant areas implemented in educational institutions of higher education is pedagogical design. The urgency of the problem is due to the social order of the society for the training of highly qualified specialists with critical design thinking, ready to solve professional problems of any level of complexity; the increased interest of scientists in the development of theoretical and methodological foundations of pedagogical design, on the one hand, and the lack of development of mechanisms for its practical implementation in higher education, methodological support tools for its implementation on the other. Students should select texts based on the language of their future specialty, make assignments for the consolidation of the passed terminology (Erofeeva \& Yusupova, 2018). The design background goes back to antiquity. Plato in the works "State" and "Laws" proposes and discusses the project "ideal state". Speaking as a practitioner of state building, Plato proposes to first build a state mentally, which is one of the first prerequisites for design. Scientific understanding of the process and results of design as a special activity began at the turn of $20-21^{\text {st }}$ centuries, which was characterized by the presence of reflection and design activities, the emergence of project terminology.

\section{KEYWORDS}

Project activities, Professional training, Future philologists, Pedagogical design, Methodological support. 


\section{INTRODUCTION}

The idea of the project method, put forward by the American teacher John Dewey, appeared in Russia as a "brigade method", however, not finding support, "immigrated" to the United States. The idea of project learning, which arose in the early $20^{\text {th }}$ century (Kilpatrik, 1925a, 1925b). Having become widespread and popular in schools in the US, UK, Belgium, Israel, Finland, Germany, Italy, the Netherlands, it has not been adequately reflected in Russia.

One of the advantages of project training is a rational combination of theoretical knowledge with their practical application to solve specific environmental problems in joint activities (Kudryavtsev, 1925).

In the modern system of higher education, there are three approaches to learning:

- In the first approach, the teacher determines what the student must learn, what knowledge and skills he must acquire. Training at this level is easy to control. This approach is most common. The key role is given to the "good lecturer". The result of training depends mainly on the preparedness and qualification of the trainee, while the position of the trainee as the subject of training is passive;

- The second approach is thematic: knowledge is acquired in the study of a specific topic within the framework of the educational subject. This approach is mainly focused on the interests of students and allows to establish links between previously studied areas of knowledge and new material. When working with the selected topic, the learner is more active;

- The third approach is problem-oriented, organized as a project. In this approach, students find a solution to the problem in the process of consideration and discussion of different points of view on the selected topic. The trainee is in the most active position (Šeškauskienè et al., 2011; Kheirabadi \& Mirzaei, 2019; Kashisaz \& Mobarak, 2018). 


\section{METHODS}

The willingness of teenagers to implement the idea through modern computer technologies and the ability to independently select and use art materials, techniques and their combinations according to the subject and the design task have noticeably increased (Erofeeva \& Yusupova, 2018; Eslami \& Ahmadi, 2019; Jabbari, Charbaghi, \& Dana, 2019).

In compliance with the purpose and the objects state above, the following research methods were employed at various stages of the research:

- Empirical: questioning, interviewing, testing, conversation, design; pedagogical experiment (ascertaining, forming and control stages);

- Methods of mathematical statistics: for quantitative and qualitative analysis of the results of the pedagogical experiment.

Effective communication, in its turn, is impossible without certain language skills (Kuzmina et al., 2018).

The pedagogical experiment was being conducted on the base of humanity and Education Science Academy (branch) in Yalta of V. I. Vernadsky Crimean Federal University.

\section{RESULTS AND DISCUSSION}

This study is aimed at testing the system of work on the preparation of future philologists for project activities and the use of the project method of training as a means of improving the quality of training of future philologists. Evaluation of the initial level of readiness of future philologists for project activities was carried out using criteria and diagnostic tools. For this purpose, criteria and indicators of readiness of future philologists for project activities were identified: 
- Motivational criterion with indicators: awareness of the importance of project activities in the profession of philologist; focus on the active use of project activities;

- Cognitive criterion with indicators: mastery of an integrated system of design and modeling knowledge, skills; knowledge of the features of the application of project activities in the teaching of philological disciplines;

- Operational criteria with indicators: formation of projective skills: search, communication, methodological, managerial, reflective, presentation, aimed at the creation and implementation of the project; formation of the ability to develop and present projects.

Based on the selected criteria and indicators, the levels of readiness of future philologists for project activities were characterized: threshold, productive, advanced.

To check the formation of the selected criteria and indicators, diagnostic methods of examination were selected. The selected criteria and indicators were checked by means of questioning, interviewing future philologists, testing, conversation, direct project activity.

The results of the ascertaining stage are presented in Table 1.

Table 1. Levels of readiness of future philologists for project activities at the ascertaining stage.

\begin{tabular}{|c|c|c|}
\hline Level & Experimental group & Control group \\
\hline Advanced & $5,47 \%$ & $6,32 \%$ \\
\hline Productive & $39,63 \%$ & $38,96 \%$ \\
\hline Threshold & $54,9 \%$ & $54,72 \%$ \\
\hline
\end{tabular}

Analysis of the results of the ascertaining experiment showed that most respondents had a threshold level: $54.9 \%$ in the experimental and $54.72 \%$ in the control groups. At the productive level were $39.63 \%$ of the respondents of the experimental and $38.96 \%$ of future philologists of the control groups. Advanced level detected in $5,47 \%$ of future philologists experimental and 6.32 per cent of the respondents of the control groups. 
The system of work on the preparation of future philologists for project activities was implemented in three stages, starting from the second year and continuing to the fourth: motivational and cognitive; procedural and technological; reflexive and creative. The developed system of formation of readiness of future philologists for project activities was based on the methodological principles of integrated, system-activity and contextual approaches and was a set of elements: target, substantive, procedural and evaluative. Selection of means of formation of readiness of students to project activity was carried out considering specifics and features of their professional activity.

The readiness of future philologists for project activities will be more effective in creating several pedagogical conditions:

- Activation of cognitive and mental activity of students;

- Creation of a creative atmosphere conducive to sustainable motivation for design and project activities;

- Practice-oriented nature of the educational process;

- Methodological support of the process of preparation of students of philological specialties for project activities;

- Professional and reflexive self-identification of the future philologist considering the specifics of the project activities.

The system of work provided for the formation of projective skills of future philologists: search; communicative; methodical; managerial; reflective; presentation.

At the first, motivational and cognitive stage (the $2^{\text {nd }}$ year of learning) the following tasks were solved: to determine the level of cognitive activity of students; to acquaint with the essence of project activities; the importance of preparation for project activities. Effective at this stage were such forms of work as monitoring the work of teachers of Philology and its analysis in the period of pedagogical practice, conversations, round table, lectures, trainings. 
The objectives of the procedural and technological stage (the $3^{\text {rd }}$ year of learning) were: to form projective skills; to improve special knowledge in the field of project activities and the ability to create their own projects of linguistic orientation. In order to solve the selected tasks, this stage was aimed at the gradual formation of such projective skills: the ability to consciously perceive information, the ability to listen to the interlocutor and analyze information, the ability to conduct a dialogue (checking the speech and theoretical readiness of students to organize project activities in the primary school), distribute work among team members according to their skills (Executive aspect), organize work in a group, predict the course of events, monitor and evaluate the work of the group (control and corrective aspect).

The reflexive-creative stage (the $4^{\text {th }}$ year of learning) of training of future teachers of philological specialties was aimed at the development, presentation and public protection of research, information, professional, practice-oriented projects. At the third stage of work the following tasks were solved: to improve projective skills, to develop creative potential of the person in the process of preparation of research, information, professional, practice-oriented projects.

The control stage of the experiment was carried out in order to check the effectiveness of the work on the preparation of future philologists for project activities. To this end, future philologists were asked to perform diagnostic techniques like the tasks of ascertaining experiment: questioning, interviewing, testing, conversation, direct project activities.

A comparative analysis of the study results for the experimental and control groups is presented in Table 2 .

Table 2. Comparative levels of readiness of future philologists for project activities.

\begin{tabular}{|c|c|c|c|c|}
\hline Groups & \multicolumn{2}{|c|}{ Experimental group } & \multicolumn{2}{|c|}{ Control group } \\
\hline Levels & $\begin{array}{c}\text { Ascertaining } \\
\text { experiment }\end{array}$ & $\begin{array}{c}\text { Control } \\
\text { experiment }\end{array}$ & $\begin{array}{c}\text { Ascertaining } \\
\text { experiment }\end{array}$ & $\begin{array}{c}\text { Control } \\
\text { experiment }\end{array}$ \\
\hline Advanced & $5,47 \%$ & $20,94 \%$ & $6,32 \%$ & $8,96 \%$ \\
\hline
\end{tabular}




\begin{tabular}{|c|c|c|c|c|}
\hline Groups & \multicolumn{2}{|c|}{ Experimental group } & \multicolumn{2}{|c|}{ Control group } \\
\hline Levels & $\begin{array}{c}\text { Ascertaining } \\
\text { experiment }\end{array}$ & $\begin{array}{c}\text { Control } \\
\text { experiment }\end{array}$ & $\begin{array}{c}\text { Ascertaining } \\
\text { experiment }\end{array}$ & $\begin{array}{c}\text { Control } \\
\text { experiment }\end{array}$ \\
\hline Productive & $39,63 \%$ & $64,3 \%$ & $38,96 \%$ & $42,69 \%$ \\
\hline Threshold & $54,9 \%$ & $14,76 \%$ & $54,72 \%$ & $48,35 \%$ \\
\hline
\end{tabular}

As follows from the comparative analysis of the results of experimental work, the level of readiness of future philologists for project activities was increased. There have been significant positive changes in the experimental group. The number of respondents with advanced (from $5.47 \%$ when ascertaining to $20.94 \%$ during the control survey) and productive (from 39.63\% during the ascertaining survey to $64.3 \%$ during the control experiment) levels significantly increased and the number of future philologists with a threshold level of readiness for project activities decreased (from $54.9 \%$ when ascertaining to $14.76 \%$ during the control survey).

The control group also experienced positive changes, although less significant. Thus, the number of respondents with advanced (from 6.32\% during the ascertaining experiment to $8.96 \%$ during the control survey) and productive (from $38.96 \%$ in the ascertaining experiment to $42.69 \%$ during the control experiment) levels increased and the number of students with a threshold level decreased slightly (from $54.72 \%$ when ascertaining to $48.35 \%$ in the control survey).

The pedagogical approach of Roskilde University is based on the idea that the student will better master the professional training if he starts with the search and formulation of the problem about interest to him. The formulated problem should be realized by the group members as real and its solution should be found within one of the educational cycles chosen by the student: humanitarian, humanitarian-technological, natural science or social (Berthelsen et al., 1985).

Work on the method of problem-oriented project is based on five grounds:

1. Problem statement: what is accepted as the main question of the projectwhat do you want to explore? 
2. Research objective: why do you want to research this?

3. Empirical base of research: what factual material will be used to solve the problem?

4. Theoretical basis of the research: within the framework of which theory will you investigate the selected problem and using what methods?

5. Methods of research: how will you carry out the planned search? (Papandreou, 1994).

One of the functions of the teacher in the role of project Manager is facilitation of the educational process. It is important that the teacher can ask problematic and leading questions, create a friendly atmosphere in the group, a positive attitude to solving problems, and not a direct guide, devoid of direct hints or prohibitions (Olsen \& Pedersen, 2003; Yepaneshnikov et al., 2017).

Creative activity within the educational project is considered as a combination of conscious psychological phenomena (synthesis, analysis, comparison, analogy) and unconscious. The activities under consideration include the following stages: data search, data study and development of new ones. The author interprets the educational project as a special didactic regime, as a cognitive and creative cooperation. The project includes three components: motive, innovative technologies and creative potential and the following stages: formation of educational space improvement; model to achieve the goals related to the creativity of students' activity; appropriate pedagogical conditions (Ignatieva et al., 2018; Mailybaev et al, 2018; Nakhaee \& Nasrabadi, 2019).

In the article by Reshetnikova (2013), the methods of training the creativity of future teachers in the process of studying philological disciplines are considered. The analysis of the literature allowed to identify such methods that are important for the process of formation of creative potential of students, based on role and problem-situational problems that affect different spheres of personality: cognitive, emotional, motivated and psychological. 
Modern philologist should not only transfer the experience of previous generations to new generations, but also to form an appropriate level of language learning, the desire for constant updating of knowledge, skills of self-education in the field of foreign language, be ready to interact in a foreign language environment, using active teaching methods. This is provided by mastering the knowledge and skills of using interactive technologies in professional activities, which are a set of interrelated actions that create pedagogical conditions, the implementation of which ensures the formation of the studied phenomenon (Lypchanko-Kovachyk, 2017).

Interest in project work and its integration into second and foreign language learning is growing worldwide. The project work leads to the purposeful use of language, as it requires the personal participation of students: from the very beginning of the project, students, in consultation with their teacher, must decide "what they will do and how they will do it". This includes not only the content of the project, but also the language requirements. Work on the project includes a variety of skills that focus on the topic of interest, rather than on specific language tasks (Sheppard \& Stoller, 1995).

\section{SUMMARY}

The specificity of the preparation of future philologists for project activities is due to the inclusion in the activities of adequate readiness, which is formed (the ability to "include" in the project, to carry out all stages of project activities, the ability to overcome psychological barriers during inclusion in the project activities).

However, at the present stage, schoolchildren are often not able to empathize, they are inclined to pragmatic reading, to receive information, and only during the analysis of a fictional work can they understand the depth of the text's intention and experience certain emotions (Kayumova et al., 2018). 
The state of the problem of preparing future philologists for project activities in foreign and domestic pedagogy is studied. In this regard, the project activities of future philologists are considered as an integrated activity, synthesizing cognitive, educational, communicative, creative activities, having a common goal, consistent methods, methods of activity aimed at achieving a common result.

A comparative analysis of the results of the experimental work showed an increase in the number of respondents with the level of readiness of future philologists of the experimental group for project activities, where significant positive changes in the redistribution of levels were revealed.

\section{CONCLUSION}

The study does not exhaust all aspects of the problem. The promising areas of research include: the improvement of didactic and methodological support, the use of information and communication technologies to prepare future philologists for project activities; the development of professional mobility of future philologists.

\section{ACKNOWLEDGEMENTS}

The work is performed according to the Russian Government Program of Competitive Growth of Kazan Federal University.

\section{REFERENCES}

Berthelsen, J., Illeris, K., \& Poulsen, S. G. (1985). Grundbog i projektarbejde: teori og praktisk vejledning. - Kbh.: Unge Pædagoger.

Erofeeva, A. A., \& Yusupova, Z. F. (2018). Actual problems of teaching russian language as the language of the specialty of foreign students. Revista Publicando, 5(16(1)), 324-331. Retrieved from https://revistapublicando.org/ revista/index.php/crv/article/viewFile/1503/pdf_1104 
Eslami, R., \& Ahmadi, S. (2019). Investigating the Role of Educational Media on Secondary School Students' Learning Process Improvement in Jahrom City. Fournal of Humanities Insights, 3(01), 13-16. doi: https: / / doi.org/10.22034/ jhi.2019.80890

Ignatieva, G., Vilkova, A., Timofeeva, E., Donskova, N., \& Smorodinskova, I. (2018). Educational Project as a way of improving students' creative activity. Revista Espacios, 39(25). Retrieved from http://www. revistaespacios.com/a18v39n25/a18v39n25p23.pdf

Jabbari, E., Charbaghi, Z., \& Dana A. (2019). Investigating the Effects of Educational and Motivational Education at Different Levels on the Performance and Application of dart throwing. Fournal of Humanities Insights, 3(02), 37-44. doi: https://doi.org/10.22034/jhi.2019.80896

Kashisaz, S., \& Mobaraki, E. (2018). The Effects of Private Education Institutes in Providing Modern Financial Knowledge in Developing Countries. Journal of Humanities Insights, 02(04), 172-178.

Kayumova, G. F., Makarova, V. F., \& Galiullin, R. R. (2018). Moral education of high school students in national (TurkiC) schools through literature. International Fournal of Mechanical Engineering and Technology, 9(10), 14671475. Retrieved from http:/ /www.iaeme.com/MasterAdmin/UploadFolder/ IJMET_09_10_150/IJMET_09_10_150.pdf

Kheirabadi, M. A., \& Mirzaei, Z. (2019). Descriptive valuation pattern in education and training system: a mixed study. Fournal of Humanities Insights, 3(01), 7-12. doi: https://doi.org/10.22034/jhi.2019.80889

Kilpatrick, W.H. (1925a). Método del proyecto. El uso de la fijación de objetivos en el proceso pedagógico. [In Russian]

Kilpatrick, W.H. (1925b). Los fundamentos del método. [In Russian]

Kudryavtsev, V.T. (1925). Educación problemática: fuentes, esencia, perspectivas. Conocimiento. [In Russian] 
Kuzmina, E. K., Nazarova, G. I., \& Nizamieva, L. R. (2018). Innovative technologies of teaching business French. International fournal of Engineering and Technology (UAE), 7(4), 85-87. Retrieved from https://www.sciencepubco. com/index.php/ijet/article/view/20390/9555

Lypchanko-Kovachyk, O. (2017). Pedagogical conditions for training students of english philology for use of interactive technologies in their future professional activity. Social work and education, 4(2), 102-115. Retrieved from http://journals.uran.ua/swe/article/view/118977

Mailybaev, G. S., Zhexembayeva, Z. R., Nurgaliyeva, S. A., Zholumbayeva, R. M., \& Utegulov, D. E. (2018). The efficiency of the education system in Kazakhstan: Programme for International Student Assessment (PISA). Opción, 34(85-2), 600-626. Retrieved from http://www. redalyc.org/jatsRepo/310/31057290025/html/index.html

Nakhaee, J., \& Nasrabadi, M. A. (2019). Strategies for Research-Centered Education of Architectural Designing by Examining the Research-Centered Activities of the Top Universities. Fournal of Humanities Insights, 3(02), 50-6. doi: https://doi.org/10.22034/jhi.2019.80898

Olsen, P. B., \& Pedersen, K. (2003). Frederiksberg: Roskilde universitetsforlag.

Papandreou, A. P. (1994). An application of the projects approach to EFL. In English Teaching Forum, 32(3), 41-42.

Reshetnikova, A. B. (2013). Creativity Enhancing Methods in the Educational Process. American Fournal of Educational Research, 1(11), 543-547. Retrieved from https://pdfs.semanticscholar. org/7898/9fa468d871232c54a3065bb39b6f5d17c9ca.pdf

Šeškauskienè, I., Gibulskienė, J., Kalèdaitè, V., \& Roikienè, D. (2011). Guidelines of competence development in the study field of english philology. Lithuanian University of Education. - October 18, 61 p. 
Sheppard, K., \& Stoller, F. L. (1995). Guidelines for the integration of student projects into ESP classrooms. In English Teaching Forum, 33(2), 10-15.

Yepaneshnikov, V. V., Kurdyumov, V. I., Zotova, L. E., Kraeva, M. U., Besedkina, N. I., \& Filipenkova, O. G. (2017). Individual Educational Paths of Students' Cognitive Activity Development. International Electronic Fournal of Mathematics Education, 12(1), 79-87. Retrieved from https://www. iejme.com/article/individual-educational-paths-of-students-cognitiveactivity-development 
Edición Especial Special Issue Octubre 2019 DOI: https://doi.org/10.17993/3ctic.2019.83-2.164-179 


$$
\text { /12/ }
$$




\title{
FORMATION OF RHETORICAL SKILLS IN SCHOOL: MENTAL FEATURES AND ACTIVE TEACHING METHODS
}

\author{
Anastasiia A. Korshunova \\ Kazan Federal University, Kazan, Russia \\ Elena M. Bastrikova \\ Kazan Federal University, Kazan, Russia
}

Sholpan K. Zharkynbekova

L.N. Gumilyov Eurasian National University, Nur-Sultan, Kazakhstan

Kuralay B. Urazayeva

L.N. Gumilyov Eurasian National University, Nur-Sultan, Kazakhstan

Karlygash S. Abylkhassova

L.N. Gumilyov Eurasian National University, Nur-Sultan, Kazakhstan

E-mail: anastasiiakorshunovarussia@gmail.com

Recepción: 05/08/2019 Aceptación: 16/09/2019 Publicación: 23/10/2019

\section{Gitación sugerida:}

Korshunova, A.A., Bastrikova, E.M., Zharkynbekova, S.K., Urazayeva, K.B. y Abylkhassova, K.S. (2019). Formation of rhetorical skills in school: Mental features and active teaching methods. 3C TIC. Cuadernos de desarrollo aplicados a las TIC. Edición Especial, Octubre 2019, 180-193. doi: https://doi.org/10.17993/3ctic.2019.83-2.180-193

\section{Suggested citation:}

Korshunova, A.A., Bastrikova, E.M., Zharkynbekova, S.K., Urazayeva, K.B. \& Abylkhassova, K.S. (2019). Formation of rhetorical skills in school: Mental features and active teaching methods. 3C TIC. Cuadernos de desarrollo aplicados a las TIC. Special Issue, October 2019, 180-193. doi: https://doi.org/10.17993/3ctic.2019.83-2.180-193 


\section{ABSTRACT}

The presence of more than twenty directions in Russian rhetoric is based on a different understanding of the effectiveness of communication. Common is the understanding of the effectiveness as an overall criterion of rhetoricalness - nonrhetoricalness speech communication. This article considers the formation of rhetorical skills in the American and Kazakh schools on the example of the study of literature in a non-native language - didactic prose of Leo Tolstoy. The article analyzes the active methods for the formation of rhetorical competence of the student in the American school, for the schools of Kazakhstan with non-Russian language of education, forecasts of active tasks on the same didactic prose of Tolstoy are offered. These scenarios of designing lessons are explained by the identification of commonality and differences in the formation of rhetorical competence. The solution of such issues is made in the article: an attempt to understand whether the recommendations for the formation of rhetorical skills in the American and Kazakh schools with non-Russian language of education are common, is there a connection with mental differences. To answer this question types of speech activity, argumentation technique, critical thinking, empathy, receptive and productive activity in the classroom (reflection) were analyzed. Comparison of teaching non-native literature in American and Kazakh schools with non-Russian language of education is based on the application of such experience in social life and the formation of students' motivation to study. The establishment of commonality and differences in the formation of effective communication skills allowed to understand the role of mental characteristics of students, the impact of national psychology of students in Kazakhstan on the cognitive and metacognitive scaffolding. The use of the same types of speech activity - listening, speaking, reading, writing - showed the dominance of speaking in the school in Kazakhstan.

\section{KEYWORDS}

Rhetoric, Effective communication, Secondary school, Second (non-native) language, Russian literature, National psychology, Mental characteristics of students. 


\section{INTRODUCTION}

The formation of rhetorical competence at school and university implies the skills of free speaking, the ability to accurately reproduce someone's speech, authentic broadcast own thoughts to the addressee of the message, the ability to build communication, prevent / solve disputes. This is how the effectiveness of communication characterized (Kachesova et al., 2018).

In this article the problem of the text interpretation at literature lessons is on the focus of view. Leaning on the provisions, provided by hermeneutic scientists, the authors regard the interpretation as a special dialogue between the reader and the text. The issue is also devoted to the problem of individual learning styles formation based on the psychological characteristics of the reader-student, the types of his representative system (auditory, visual or kinesthetic). Based on the facts found identified according to the experiment authors have developed the idea of forming individual ways for learning literature (Golikova et al., 2016; Kheirabadi \& Mirzaei, 2019; Córdova-Rangel et al., 2017).

The problem of interest in reading for integrated school lessons by means of visual practices is considered by scientists of the Kazan school (Vakhrameeva et al., 2016; Andrianova et al., 2017; Kashisaz \& Mobarak, 2018). The authors showed a steady decline in interest in reading in Russia, as was observed in many countries around the world. The article proposes an approach to increase interest in reading by illustrating. The authors believe that the integrated lessons of literary reading and drawing contribute to the immersion in a literary text, and visual language more understandable for the perception of students of the elementary school than the abstract language of literature.

Selection of authentic texts and methods of work with them are important in the study of literature in the second language. The authors of the experimental work aimed at the use of the effective ways of teaching communicative competencies to the full-time and part-time first-year students learning foreign languages at the language department by means of the novel «The Moon and Sixpence», written 
by the prominent English writer William Somerset Maugham, consider that this approach helps to form the communicative competence of students (Varlamova et al., 2016; Subich et al., 2016; Eslami \& Ahmadi, 2019; Kondubaeva et al, 2018).

In this sense, interest was caused by the planning of lessons in the American school in the study of Russian literature on the material of didactic prose by Leo Tolstoy, in textbooks for 7, 8, 10 classes and in 11-12 classes in the textbook "World literature" publishing "McDougal Littell" (Applebee, 2008a; 2008b; 2008c; 2008d).

The purpose of the article is to establish commonality and differences in the American and Kazakh schools in the development of effective communication skills, as well as to identify the relationship between the national psychology of students and the impact on active teaching methods in the school in Kazakhstan.

\section{METHODS}

The authors of the considered textbooks define didactic literature as "literature intended mainly for the purpose of explaining or conveying a moral message" (Applebee, 2008c). Accordingly, the understanding, analysis and interpretation of instruction, morality in the works of Leo Tolstoy are the main strategies of semantic reading.

In order to arouse interest in the work, much attention is paid to the stage of "challenge" . Therefore, before studying the short story "The old grandfather and his little grandson" (grade 8), the question is: "How well do we treat elder?" And for the understanding of key ideas pro-extermination questions can be specified (Applebee, 2008b). This sets the context of reasoning and activates the mechanism of empathy. Usage of the mechanism on the example of studying a non-native (second) language on the example of students of non-linguistic specialties in universities in Kazakhstan is described in the articles of the authors of this article (Abylkhassova, 2019; Birjandi \& Jazebi, 2014; Jabbari et al., 2019). 
In the study of literature in a second language by the authors of the widely used ways of raising intercultural dialogue. Hence, it appeals to the method Comparing Theme. It builds a comparative study of the short story of Leo Tolstoy, written on the basis of folk tale, and the Japanese folk tale "The wise old woman", retold by Yoshiko Uchida. The method Comparing Theme develops students ${ }^{6}$ understanding of the term universal theme as an understanding of the unity of the world cultural process, activating intercultural dialogue as an object and tool of learning. The method Literary Analysis becomes the basis of the guiding strategy for the formation not only of the socio-cultural context of the study, but also of rhetorical culture (Applebee, 2008b; Nakhaee \& Nasrabadi, 2019).

Receptive activity is also provided by the task List it. After reading the text, the transition to reflection is also a step-by-step system. First, it is the understanding and interpretation as the ways to monitor the speech competence of students and their rhetorical culture, which are carried out at the stage After reading. Therefore, while studying the short story "The Old grandfather and his little grandson" Comprehension is accomplished by defining Recall, whereas Writing for Assessment suggests a cognitive scaffolding (Birjandi \& Jazebi, 2014; Barzamini, O. (2018). Cognitive scaffolding is offered to Read the prompt.

It is interesting how the authors differentiate the activities of students and direct them to progression. The recommendation Plan your writing teaches the operations and procedures of thinking, working with the table Points of Comparison, which sheds light on the proposed in the tutorial plan essay.

The connection reading with writing is through Reading strategy: it is important to set a purpose for reading. That is how the term universal theme is achieved.

Differentiation of student activity is supported by the task Draft your response. Methods of comparing the passage from the new Testament and Tolstoy's story are divided into a number of operations that determine the content of each part 
of the essay: introduction, body, conclusion. As a test of the correctness of judgments, understood in the rhetorical aspect as persuasiveness, the stage of Revision is proposed (Applebee, 2008c).

Channels of information perception in the study of literature in a non-native language achieve efficiency by working with visibility. For example, the authors use the Analyze visuals in order to better understand the text when studying the story "The old grandfather and his little grandson" (Applebee, 2008b).

It is necessary to pay attention to how the motivation for reading is caused by the heading Author online, where in the biography and literary destiny of the writer the emphasis is made on the secret of his popularity and world recognition.

\section{RESULTS AND DISCUSSION}

Kazakhstan is a country of natural bilingualism. From the 2017-18 academic year, the reform of secondary education is announced here. The widespread introduction of the communicative-activity approach has led to the updating of the content of all textbooks. For the study of literature in a non-native language, the important role of active methods was determined by the proximity of didactic methods, the role of empathy, changing the educational paradigm, with the strengthening of the role of skills, critical thinking, the ability to apply the knowledge in life, etc.

In the present part of the development of active tasks on the same material didactic prose by Leo Tolstoy. However, the focus of based on the context of cognitive scaffolding with different mental - Kazakhstan (not Kazakh) environment.

Here, under the stage of "challenge", before studying the story "The Old grandfather and his little grandson" communication with personal experience of students in a society with strong patriarchal values, deep rooted household of Islam, elders' piety, the actual tasks associated with a description of the signs of 
old age. While in the American school of reasoning about the reasons for respect for old age require the involvement of texts of another culture (Japanese folk tales) with an emphasis on universal for the peoples of the world theme.

Attention to the problematic issues that require a detailed answer in a society with pronounced etiological attitudes (to the listener) require the activation of speaking. Therefore, it is recommended as answers that require a detailed answer: "Why did grandfather keep silent?", "What lesson did the boy learn from this story? How does this action to characterize the personality of the hero?" and giving the answer by the personal relation.

The formulation of personal attitudes, opinions as a strategy of personalityoriented approach is due to the cognitive setting, guiding the student with independent work on the story: "Formulate the moral of the story. What are the signs of didactic prose" to reflection - "Write a story about your grandfather or grandmother, or about such grandfather and grandmother they would like to be seen".

The difference between the tasks completing the study of the story in the societies of American and Kazakh culture is obvious. At the heart of reflection, producing the same rhetorical competence are different ways of argument.

We are close to the experience of commented reading and analysis of the authentic fictional text by A.P. Chekhov by philological students in the classes of Russian as a foreign language described in one of the articles of teachers of Kazan Federal University. The authors consider: «Foreign students learn about the culture and perception of the Russian people, expand their vocabulary and improve their communication skills through working with the literary text, so it is important to choose an appropriate pedagogical approach» (Valeeva et al., 2018).

The argument of the American student is aimed at the universality of the topic, which is obvious for Kazakhstan initially. The shift of the discursive core of the argument to the reputational value of senior members of the family in a society with a traditional minority structure (when the heir is the younger son, and he 
also in a traditional family takes care of the parents) is a model of behavior, contains ready-made patterns of behavioral type. At the same time, the social contradictions that have affected the traditional society are also known to students. The reflection, which is carried out in the course of independent work, makes it possible to correct the existing socio-cultural stereotypes of the institution of the family, opening the horizons of their potential change based on a comparison of the real and possible worlds.

In the national school of Kazakhstan, during the dictionary work, preference is given to such types of work: the formulation of a certain sentence in other words, the selection of synonyms, work with the meanings of words with the help of a dictionary, work with the methods of word formation to understand the semantics, explanation with the help of examples of the meanings of idioms, phraseological phrases, self-identification of signs of style. Attention to the search for information using electronic resources to compare the native culture and the studied contributes to the understanding of unity and national identity. For example, commenting on the cases of different laughs in the Russian language and native, students are imbued with an understanding of the sound symbolism of the native language, in Kazakh, for example, the relationship between the signifier and the signified gave rise to an abundance of ideophones with their sound semantics (Khusainov, 1988). One of the common ways' students explain the meaning of words is a contextual approach.

The transition to productive activities defines as new approaches reflection, allowing students to formulate the moral of the story, and - respectively - to determine the genre characteristics of didactic prose.

\section{SUMMARY}

Comparison of teaching non-native literature in American and Kazakh schools with non-Russian language of instruction is based on the application of such experience in social life and the formation of motivation of students to study. 
The establishment of commonality and differences in the formation of effective communication skills allowed to understand the role of mental characteristics of students, the impact of national psychology of students in Kazakhstan on the cognitive and metacognitive scaffolding.

The use of the same types of speech activity - listening, speaking, reading, writing - showed the dominance of speaking in the school of Kazakhstan.

Different contents of argumentation, different operations of critical thinking, different forms of inclusion of empathy, receptive and productive activity at a lesson are revealed.

\section{CONCLUSIONS}

The commonality of didactic approaches in the formation of rhetorical competence in the American and Kazakh schools with non-Russian language is revealed in the following:

- Using the visual channel as a conscious perception and processing of information as an activating basis for writing an essay;

- Inclusion of empathy in the context of reasoning by modeling educational situations involving personal social experience;

- Attitude to the argument as a sign of rhetorical competence of the student;

- Connection of cognitive and metacognitive scaffolding with historical, cultural and social context of the studied literature.

Commonality can be traced and the mechanism of motivation to read. This is the content of the columns containing a brief information about the writer as a system of entertaining facts that explain the recognition and reputation / fame / popularity in the world. 
The differences are due to the predominant passive type of perception of information in the Kazakh national school due to the formation of several centuries of etiological attitudes to the role of the listener. Hence the main differences in didactic approaches:

- Accentuation of problematic issues that require a detailed answer in order to enhance speaking in the Kazakh school;

- Orientation in the argument on the mental characteristics of students, the basic values of the ethnic group;

- Priority design of brainstorming in the pro and contra systems, protection of opinions and correction of the opponent's worldview in the process of argumentation.

The main difference lies in the strategy of the dictionary work. In the American school, it involves the ability to build communication, prevent / resolve disputes, identify communication errors and see the causes of these errors, while in schools of Kazakhstan in teaching a second language is a priority to expand the vocabulary.

\section{AKNOWLEDGEMENT}

The work is performed according to the Russian Government Program of Competitive Growth of Kazan Federal University. Article is written within the framework of the project "Formation of a new type of professional multilingual personality in the conditions of multilingual education in Kazakhstan" under the contract N. ${ }^{\circ} 132$ from "12" March 2018. 


\section{REFERENCES}

Abylkhassova, K. (2019). Formation of reading literacy in US schools. Current experience for updating Kazakhstan textbooks. The III All-Russian scientificpractical conference «Pedagogical education: optimization, modernization and development forecastr. Moscow: RUDN.

Andrianova, N. S., Nizamieva, L. R., Nazarova, G. I., Ostroumova, O. F., \& Leblanc, C. (2017). The Development of Students' Cognitive SelfStudy While Teaching Reading in FL Training. Fournal of History Culture and Art Research, 6(5), 321-326. doi: https://doi.org/10.7596/taksad.v6i5.1258

Applebee A. N. (2008b). "Literature (Grade 8). Student textbook", Austin, Texas: McDougal Littell, 1067 p.

Applebee A. N. (2008c). "Literature (Grade 10). Student textbook", Austin, Texas: McDougal Littell, 1209 p.

Applebee A. N. (2008d). "World Literature. Student textbook", Austin, Texas: McDougal Littell, 1379 p.

Applebee A.N. (2008a). "Literature (Grade 7). Student textbook", Austin, Texas: McDougal Littell, 999 p.

Barzamini, O. (2018). An Analytical Review of Civil Liability in Mines, a Look at the Explosion of the Winter Yoart of Azadshahr city. UCT Journal of Social Sciences and Humanities Research, 6(3), 8-15.

Birjandi, P., \& Jazebi, S. (2014). A comparative analysis of teachers' scaffolding practices. International Fournal of Language and Linguistics, 2(3), 154-164. doi: https://doi.org/10.11648/j.ijll.20140203.14

Córdova-Rangel, A., Escalera-Ghavez, M. E., \& Gasca, S. B. (2017). Mathematics really generates anxiety? Empirical Study in middle school students. International Electronic Journal of Mathematics Education, 12(1), 8897. Retrieved from https://www.iejme.com/article/mathematics-reallygenerates-anxiety-empirical-study-in-middle-school-students 
Eslami, R., \& Ahmadi, S. (2019). Investigating the Role of Educational Media on Secondary School Students' Learning Process Improvement in Jahrom City. Fournal of Humanities Insights, 3(01), 13-6. doi: https:/ / doi.org/10.22034/ jhi.2019.80890

Golikova, G. A., Zamaletdinov, R. R., Vafina, A. H., \& Mukhametshina, R. F. (2016). The "New" Strategy in Teaching Literature in a Multiethnic Environment (as exemplified by the Republic of Tatarstan). International fournal of Environmental and Science Education, 11(6), 1237-1246. Retrieved from https:/ / eric.ed.gov/?id=EJ1114295

Jabbari, E., Charbaghi, Z., \& Dana A. (2019). Investigating the Effects of Educational and Motivational Education at Different Levels on the Performance and Application of dart throwing. Fournal of Humanities Insights, 3(02), 37-44. doi: https://doi.org/10.22034/jhi.2019.80896

Kachesova, Y., Klink, E. I., Kopnina, G. A., Kukueva, G. V., Lukashevich, E. V., Urazaeva, K. B. ... \& Shmakov, A. A. (2018). Rhetoric. The educational book for a magistracy in the direction / specialty "Philology" in universities in Russia and Kazakhstan. Retrieved from http:/ / elibrary.asu.ru/ handle/asu/6562

Kashisaz, S., \& MobarakI, E. (2018). The Effects of Private Education Institutes in Providing Modern Financial Knowledge in Developing Countries. Fournal of Humanities Insights, 02(04), 172-178. doi: https://doi.org/10.22034/ jhi.2018.80887

Kheirabadi, M. A., \& Mirzaei, Z. (2019). Descriptive valuation pattern in education and training system: a mixed study. Fournal of Humanities Insights, 3(01), 7-12. doi: https://doi.org/10.22034/jhi.2019.80889

Khusainov, K. (1988). Sound visualization in the Kazakh language (2nd ed.). AlmaAta, Nauka Publisher.

Kondubaeva, M. R., Bekalay, N. K., Aubakirova, A. K., Ongarbaeva, A. T., \& Tolkinbayev, A. K. (2018). The problem of correctness and reliability of the study in trilingual education. Opción, 34(85-2), 517-543. 
Nakhaee, J., \& Nasrabadi, M. A. (2019). Strategies for Research-Centered Education of Architectural Designing by Examining the Research-Centered Activities of the Top Universities. Fournal of Humanities Insights, 3(02), 50-6.

Subich, V. G., Shangaraeva, L. F., \& Zakirova, L. R. (2016). Improvement of the English language communicative competencies by means of authentic texts. Fournal of Language and Literature, 7(2), 257-261. doi: https://doi. org/10.7813/jll.2016/7-2/48

Vakhrameeva, T., Emanova,J., \& Yao, M. (2016). Forming interest in reading for integrated school lessons by means of visual practices. International fournal of Humanities and Cultural Studies (IFHCS). Retrieved from https://www.ijhcs. com/index.php/ijhcs/article/view/2598

Valeeva, D. R., Ershova, A. A., \& Latypova, E. (2018). Short Stories Of AP Chekhov About Child's World On The Lessons Of The Russian Language As A Foreign ("Grisha"," An Incident"," Children"). Modern Fournal of Language Teaching Methods, 8(10), 320-326.

Varlamova, M. Y., Bochina, T. G., \& Miftakhova, A. N. (2016). Interactivity in teaching a foreign language. The Language Learning Journal, 7(3), 190-194. doi: https://doi.org/10.1080/09571736.2014.994183 


$$
\text { /13/ }
$$




\title{
RATING CONTROL IN LEARNING TO RUSSIAN AS A FOREIGN LANGUAGE
}

\author{
Anna Alexandrovna Erofeeva \\ Kazan Federal University, Kazan, Russia \\ Tatyana Alexandrovna Korneyeva \\ Kazan Federal University, Kazan, Russia \\ Tatyana Damirovna Markova \\ Linguistics University of Nizhny Novgorod, Russia \\ E-mail: tatyana.tak1110@gmail.com
}

Recepción: 05/08/2019 Aceptación: 16/09/2019 Publicación: 23/10/2019

\section{Citación sugerida:}

Erofeeva, A.A., Korneyeva, T.A. y Markova, T.D. (2019). Rating control in learning to Russian as a foreign language. 3C TIC. Cuadernos de desarrollo aplicados a las TIC. Edición Especial, Octubre 2019, 194-205. doi: https://doi.org/10.17993/3ctic.2019.83-2.194-205

Suggested citation:

Erofeeva, A.A., Korneyeva, T.A. \& Markova, T.D. (2019). Rating control in learning to Russian as a foreign language. 3C TIC. Cuadernos de desarrollo aplicados a las TIC. Special Issue, October 2019, 194-205. doi: https://doi.org/10.17993/3ctic.2019.83-2.194-205 


\section{ABSTRACT}

The urgency of the research is in seeking for the methods and techniques to intensify the learning activities of students in learning to Russian as a foreign language, to increase their motivation, to develop creative potential, mutual help and cooperativeness in a classroom environment and outside the classroom. One of the effective methods for improving learning is the rating control of the educational activities of students. This article is supposed to substantiate the effectiveness of the systematic use of rating control and ranking students at each stage of the Russian language learning as foreign. The basic research methods are the modeling of study process, the methods of analysis and synthesis, lesson observation, experiment (diagnostic, prognostic, organizational, practical, generalizing). The results of the study show the effectiveness of applying systematic ranking of the students within the classes following on from the results of the educational task, the effectiveness of the model of classes in Russian as a foreign language in which a student who occupies the highest position in the ranking is always first to be tested. The study of the impact of rating control system in teaching Russian as a foreign language on student performance and increasing their level of language competence plays an important role in improving the methods and techniques of organizing educational work in Russian.

\section{KEYWORDS}

Russian as a Foreign Language, Methods, Control, Rating, Ranking. 


\section{INTRODUCTION}

Differentiation in teaching and an individual approach to students in the process of teaching of Russian as a foreign or non-native language often leads to an underestimation of the competitive factor in teaching and the orientation of teachers to "average" students or low-performing students. This reflects a bad effect on the educational process and personal achievements of students. Meanwhile, the focus of the teaching methodology and didactic material on highachieving students allows making great educational progress and stimulating the educational and cognitive activity of all students in the training group, regardless of the level of competence in a discipline. A similar system for organizing educational activities of students in Russian as a foreign language is based on a constant ranking of students in terms of the quality and efficiency of learning activity.

One of the effective methods for generating a higher return from education is the rating control of learning activity of the students. Rating is generally understood as an individual numerical indicator of an evaluation of attainments in studies. It is obtained by adding the rating marks obtained as a result of the assessment of individual educational activities, if possible, considering the coefficient of significance ("weight" coefficient) of these actions in achieving educational goals (Chernyavskaya \& Grechin, 2008). The main principle of rating is ranking. Rating learning technology enables to obtain objective data on the level of student's grades. The scientific literature differentiates the cumulative ratings Olympic, leadership, certificate ratings - from the academic achievement ratings (Chernyavskaya \& Grechin, 2008). The grades for the first three ratings are cumulated during the last years of schooling and are extended to the next year. The ranking of academic achievements summarizes the grade point average of all academic disciplines. Thus, rating control is one of the modern means of assessing the quality of education and is applied, as a rule, at the final stages of training, when it is necessary to differentiate the students in order to distribute them among subject major or academic classes. Institutions of higher learning 
use the system of rating control more consistently in the form of a grade-rating system to assess the quality of students' academic work using block-modular learning technology (Arkayeva, 2009).

Rating control in the system of learning to Russian as a foreign language has not been practically studied. As a rule, scientific works dealing with the methods of learning to Russian as a foreign language discuss the system for testing foreign students and methods for the development of control and test materials for various levels (Balykhina, 2007). Koryakina (2017) in her work considers the functions of control (verification, training, developmental, educational), the types of control (preliminary, current, mid-term, final), the methods (written assignments and tests) and the forms of control (individual and frontal). The importance of using all types of control in teaching of a foreign language is noted (Koryakina, 2017). However, the actual rating control has remained out of eyeshot of the scholar.

From our point of view, the essence of rating control in the methodology of learning to Russian as a second language lies primarily in the constant ranking of the results of students performing learning tasks. On this basis an effective model of classes in Russian as a foreign language is built, according to which a student who occupies the highest position in the ranking is always first to be tested. This means that the teacher starts marking test of the student who completed the previous task best and then in descending order. We should pay attention to the mobility of the rating within one lesson and in learning overall. The students' ranking is built upon the completion of a concrete task, and during the lesson the student's place in the ranking can be changing. The main condition is that the student who is the first to have performed the previous task speaks, then according the place in the ranking. With such an organization of the control system, considerable attention is paid to high-achieving learners. Low-performing students get additional opportunities to recognize by listening and solidify the knowledge to have been acquired and demonstrate certain success in learning. 


\section{METHODOLOGY}

The main research methods include: theoretical analysis of scientific and educational literature, modeling of the learning process, methods of analysis and synthesis, lesson observation, experiment (diagnostic, prognostic, organizational, practical, generalizing), conversation method. The study of specialized literature on the topic made it possible to identify the main methods and techniques used in learning to Russian as a foreign language, focus on communicative teaching technologies, especially the interaction with the students during the lesson (Safonova \& Lukoyanova, 2016; Fazliakhmetov \& Yusupova, 2018; Rakhimova et al., 2017), organize a problem-based dialogue (Fattakhova et al., 2018), study the history of the issue (Safonova \& Erofeeva, 2017; Andrade, 2017). Modeling of the learning process made it possible to identify learning strategies and tactics, predict student behavior, and optimally organize the educational process. Lesson observation made it possible to collect factual material and analyze the learning outcomes. Using the methods of analysis and synthesis, the results of experiments have been summarized and analyzed, and an idea about the further improvement of the learning process have been formed. The experimental method made it possible to trace changes in the quality of knowledge and skills of students following from the result of using the rating control technique. The method of conversation contributed to the identification of psychological characteristics of students and the impact on them of the above learning system.

\section{RESULTS AND DISCUSSION}

The testing of the rating control methods in class on Russian as a foreign language was carried out based on the Kazan (Privolzhsky) Federal University during the 2017-2018 and 2018-2019 academic years in the groups of students from Xi'an Petroleum University (China) who were undergoing internship in Russian at the department Russian language and its teaching methods. The average age 
of the students was 20 years, the time of studying the Russian language before arriving in Kazan was two years, the time of studying at KFU was eight months (excluding winter holidays).

Testing was carried out in two stages. The first stage (diagnostic, prognostic, organizational, practical stages of the experiment) is the academic year 20172018, one group (12 people), courses on practical grammar of the Russian language and improvement of written language. The second stage (practical, generalizing the stages of the experiment) - the academic year 2018-2019, one group (12 learners) - the courses on practical grammar of the Russian language, on improving written language (eight months), on morphology (four months); two groups (11 and 12 learners) - morphology (four months).

During the first stage of testing based on observation methods and primary control methods, the psychological and pedagogical features of a group of Chinese learners of a specified age and their level of knowledge of the Russian language which turned out to be quite low, as well as a high level of motivation and interest in the learning process, were revealed. Based on the obtained psychological and pedagogical results and considering the individual capabilities of students, it was decided to use the methods of rating control of the results of students' attainment at each stage of the lesson on the above courses. Then, during the four months of training, the teacher began to grade each performed task of the student who completed the previous task best, and then in descending order. The ranking of students was built upon the completion of a certain task, and during the lesson the student's rank could repeatedly change. The students' rating was mobile within the same lesson and in the study overall. The main condition was that the student who took the previous assignment best to speak first, then according to the ranking. With such an organization of classes, considerable attention was paid to the advanced students. The weaker students received additional opportunities to recognize by listening and solidify the studied material and demonstrated concrete success in learning. When changing the place in the ranking, as a rule, the sequence of positions of two learners changed, less often - of three ones. 
In the process of teaching practical grammar and improving the written language of the students, all types of speech activities were involved: reading, writing, listening, speaking, but the priority was given to speaking, that is, to developing skills in the possession of grammatical material in oral form (based on a communicative technique).

Significant conditions for implementing the proposed model were: a) a high pace of the lesson, b) an obligatory testing of all students in the group, c) the time limit for an answer (3-5 minutes on average), d) putting grades for each completed assignment and announcing the results to the students (at the end of the lesson).

Testing of the methodology showed significant achievements of a group of trainee students in four months and an increase in the level of formation of language competence.

The negative aspects of testing the systematic ranking of students by the level of assignments to be performed in the academic year of 2017-2018 should include: 1) psychological discomfort of the student who is always the last on the list; 2) gradually forming psychological fatigue of the group as a result of intensive educational activities. To reduce the negative consequences of studying in the second semester (the next four months), a system of encouraging tasks for low-performing students (a variety of creative tasks that helped them realize their potential and improve speech quality) was devised and a group work with account taken of the interaction of advanced and weaker students (dialogs, mutual testing, mutual control, etc.) was organized. However, the basic principle of rating control and ranking was retained.

During the second stage of testing in the academic year of 2018-2019, the methods and techniques for organizing learning activities of foreign students and the system for organizing rating control (with application of the basic principles) were improved. When analyzing the learning outcomes of students in the group in which the ranking system was tested, a significantly higher level of formation of language competence (especially in speaking) was observed with other groups in the study group. It is characteristic that the inclusion of two other groups in the 
experiment at the beginning of the second semester in the course of morphology also showed a significant intensification of students' learning activity and the improvement of all types of speech activity. At the stage of 2018-2019, there were no negative effects in the form of psychological fatigue of the group or psychological discomfort of the weakest student.

As a result of testing, a learning model focused on advanced students, while studying the practical grammar of the Russian language and improving written language, significant successes of all students of the foreign group of students studying the Russian language, their interest in the final learning results, cooperativeness and mutual help were noted. This has confirmed the assumptions by the scholars of Kazan University in several works dealing with the peculiarities of teaching foreign students to the Russian language (Safonova \& Lukoyanova, 2016; Fazliakhmetov \& Yusupova, 2018; Rakhimova et al., 2017; Fattakhova et al., 2018; Safonova \& Erofeeva, 2017). The interest in learning the Russian language, the desire to take a higher position in the ranking, the obvious results of successful educational activities motivate the students who are learning Russian to learn it further.

\section{SUMMARY}

Thus, the following should be attributed to significant research results. 1) The necessity of a scientific description of the rating control system in learning to Russian as a foreign language has been substantiated. 2) The effectiveness of the systematic ranking of students in the classroom based on the results of the educational task has been proved. 3) The effectiveness of the model of classes in Russian as a foreign language has been proved, in which a student who occupies the highest position in the ranking is always first to be tested. 4) The need for objectivity in assessing the knowledge and skills of the students, the strictness and at the same time goodwill of the teacher, an elaborated system of moral encouragement of the participants in the learning process has been emphasized. 5) Attention is drawn to the mobility of rating within one lesson and in training 
overall. The ranking of students is built upon the completion of a concrete task, and during the lesson the student's place in the ranking can repeatedly change. The main condition is that the student who is the first to perform the previous task speaks first, then according to the ranking. 6) It has been revealed that with such an organization of the control system, considerable attention is paid to highperforming students. Low-performing students receive additional opportunity to recognize the material by listening and solidify it and demonstrate certain success in learning. 7) Important conditions for the implementation of the model are: a) a high pace of the lesson, b) an obligatory testing of all students in the group, c) the time limit for an answer (3-5 minutes on average), d) putting grades for each completed assignment and announcing the results to the students (at the end of the lesson). 8) The stimulating effect is the pair and group work of the students, challenging tasks.

\section{CONCLUSIONS}

Even though the methods of learning to Russian as a foreign language has been developed quite comprehensively and in detail, the questions concerning the intensification of learning activities of students and the maintenance of their interest in the subject have been remained within eyeshot of methodological scientists so far. In this respect, the methods of rating control and ranking the learners according to the results of their learning activities deserves attention and requires having been further researched and tested in the context of other disciplines of learning to Russian as a foreign language.

\section{ACKNOWLEDGMENTS}

The work is performed according to the Russian Government Program of Competitive Growth of Kazan Federal University. 


\section{REFERENCES}

Andrade, M. S. (2017). Institutional Policies and Practices, and Tracking International Students. Fournal of international students, 7(1), 1-6.

Arkayeva, R. P. (2009). The Qualimetrical approach in quality management of formation of students. Vestnik Severo-osetinskogo Gosudarstvennogo Universiteta imeni K.L.Khetagurova-Bulletin of the North-ossetian State University named after C.L.Khetagurov, Vladikavkaz, Severo-osetinskiy Gosudarstvennyi Universitet, 3, 44-46.

Balykhina, T. M. (2007). Methods of teaching Russian as a non-native (new). Moscore, Izdatel'stvo Rossiyskogo universiteta druzhby narodov, 185 p.

Chernyavskaya, A. P., \& Grechin, B. S. (2008). Modern means of evaluating learning outcomes. Vestnik Yaroslavskogo Gosudarstvennogo Pedagogicheskogo Universiteta imeni K.D. Ushinskogo-Bulletin of the Yaroslavl State Pedagogical University named after KD Ushinsky, Taroslavl, Taroslavskiy Gosudarstvennyy Pedagogicheskiy Universitet, 9, 98.

Fattakhova, N., Faizullina, N., \& Mubarakshina, A. (2018). Teacher and student relation in a dialogue. Modern Fournal of Language Teaching Methods, 8(12), 743-755.

Fazliakhmetov, I., \& Yusupova, Z. (2018). Methodological heritage of Kazan scientists in the field of teaching the Russian language. IIOAB FOURNAL, 9, 174176.

Koryakina, A. V. (2017). Point-rating system as a means of assessing the formation of competencies. Scientific and methodical electronic journal "Concept"Scientific and methodical electronic journal "Concept", Moscore, Izdatel'stvo MTSITO, 25, 216-219.

Rakhimova, D., Ghernysheva, A., \& Komar, N. (2017). Speech-behavioral tactics of apologi in secular and religious cultures. Ad Alta-journal of interdisciplinary research, 7(2), 190-192. 
Safonova, S. G., \& Erofeeva, I. V. (2017). Conceptual opposition "friend enemy" in Russian medieval period. Astra Salvensis, 5(10), 199-204.

Safonova, S. G., \& Lukoyanova, Y. K. (2016). The teaching of speech etiquette in the course of Russian as a foreign language. Modern fournal of Language Teaching Methods (MFLTM), Special Issue (December 2016), 81-85. 


$$
\text { /14/ }
$$




\section{COMPETENCE OF GRADUATES OF HIGHER PROFESSIONAL EDUCATION AS AN OBJECT OF SOCIOLOGICAL REFLECTION}

Valentina Vladimirovna Fursova Kazan Federal University, Kazan, Russia

Makpal Barkiyayevna Syzdykova Kazan Federal University, Kazan, Russia

Talant Dyusenuli Bimakhanov Kyzylorda State University named after Korkyt Ata

Maria Alievna Makhambetova Kazan Federal University, Kazan, Russia

\section{Citación sugerida:}

Fursova, V.V., Syzdykova, M.B., Dyusenuli Bimakhanov, T. y Makhambetova, M.A. (2019). Competence of graduates of higher professional education as an object of sociological reflection. 3C TIC. Cuadernos de desarrollo aplicados a las TIC. Edición Especial, Octubre 2019, 205-217. doi: https://doi.org/10.17993/3ctic.2019.83-2.206-217

\section{Suggested citation:}

Fursova, V.V., Syzdykova, M.B., Dyusenuli Bimakhanov, T. \& Makhambetova, M.A. (2019). Competence of graduates of higher professional education as an object of sociological reflection. 3C TIC. Cuadernos de desarrollo aplicados a las TIC. Special Issue, October 2019, 205-217. doi: https://doi.org/10.17993/3ctic.2019.83-2.206-217 


\section{ABSTRACT}

The relevance of the chosen research topic lies primarily in the increasing share of young professionals in the workforce and the need to develop, in this regard, measures to address problems related to youth unemployment in Kazakhstan. The authors note that the education system does not always form students' competencies that are in demand on the labor market, as a result of which employers do not want to hire university graduates, prefer workers with experience, which contributes to the growth of unemployment among university graduates. In this regard, the authors conducted an expert survey of the heads of organizations in order to identify their views on the competencies of university graduates needed in the labor market (130 people were interviewed).

Recommendations for improving the education system with the aim of forming competencies important in the modern labor market are offered.

\section{KEYWORDS}

Youth, University Graduates, Competencies, Employer, Competitiveness, Unemployment. 


\section{INTRODUCTION}

Youth unemployment in modern Kazakhstan is due to the fact that young professionals after graduation are looking for work but face the problem that employers do not need them due to the fact that universities do not teach the necessary competencies in demand in the labor market. Well-known British sociologist J. Goldthorpe in the analysis of the labor market introduces the concept of "labor situation" and defines it as a set of social relations in which "a person is involved at work through his position in the division of labor" (Goldthorpe et al., 1987). In this context, young people cannot find a job because of the incompatibility of their competencies with the skills required by employers, and therefore the "work situation" is violated. Market conditions are a "set of material rewards and life chances", as R. Erickson notes (Erikson \& Goldthorpe, 2012, p. 176). As for life chances, they are low among Kazakhstani youth.

Social problems of unemployment among young specialists are studied by Ganskau, Ponomarenko, Geleta, Akulich, Zaslavskaya, Savinova, Borisova, Kuzmin, Maslova, Vidyapin, Zhuravleva. It is sociologists who mainly attracted the attention of the public to employment as a social problem.

The modern labor market in Kazakhstan is characterized by high level of unemployment, late payroll, a gap between the needs of society and prestigious professions, dissatisfaction of employers with the education system, etc. (Shedenova, 2008, p. 518-522). The entry of young people into the labor market is accompanied by considerable difficulties and contradictions. The reason for these problems may be related to the incompetence of young people due to the lack of competencies, since universities do not train practically oriented specialists, and university education lags the needs of employers. Therefore, a significant part of graduates does not find work in their specialty or do not get a job at all, which leads to an increase in unemployment among young people. As a result, the invested finances for their education are not justified. There is also a reluctance of employers to hire graduates without work experience because they believe that they lack practical skills and professional competencies. Therefore, 
the relevance of research is that it is necessary to look for new ways to solve the problem of youth employment in the labor market in accordance with the needs of social development and the current level of economic development. The topic of the research is at the junction of several topical issues of modern society, such as: upbringing and education of young people, comprehensive personal development, scientific management of society.

\section{METHODOLOGY}

In order to assess the opinion of employers about the professional training of specialists by the university and further improve the quality of educational services of the year, a survey was conducted using a method of non-formalized interview among 130 business leaders (April 2019). The survey involved respondents engaged in various forms of professional activity, as well as in various organizational and legal forms of entrepreneurship.

\section{RESULTS AND DISCUSSION}

Employment of university graduates is not only a problem of graduates, but also a problem of these universities. In each university there are two closely related subjects of the market: the first is the educational services market, and the second is the labor market. Therefore, the competitive advantage of an university in the market of educational services is crucial, increasing the guarantee of employment after training and attracting a greater number of applicants. The main task of modern education is to prepare the best specialists, which must be competitive in the labor market. A young specialist should be competent, knowledgeable, versatile, highly qualified specialist who can quickly adapt to the changes that are taking place, able to solve the industrial and innovative situation, is inclined to show self-esteem in society, also able to freely Express their opinion, knowing the high level of knowledge with higher education, have a high level of knowledge, have higher education, possess deep knowledge of the national language, history and culture. 
In modern conditions, universities offer mainly to study for prestigious "market" specialties, since, on the one hand, they are in demand (they are quite popular), on the other hand, they require minimal investments from universities in the form of special equipment, etc. These specialties do not mean that the skills and abilities have been programmed into a specific field, but only store them as providers of quick-reaction capabilities in the market, which is very important at the present time. Applicants consider higher education not as an investment, but as the achievement of social status, which frees the departments of employment of students at universities from the responsibility for the employment of graduates. This conclusion can be made based on how the above departments deal only with collecting certificates of employed graduates. Also, the success of the graduates' professional career is estimated based on the rating system of universities in Europe and America. The latter are interested in a detailed continuation (through research) of their former graduates working career.

The problem of personnel is most relevant for employers. In the field of vocational education, the employer has a demand for the most diversified specialists with higher education. The modern information society requires the training of specialists with a high level of information competence, the ability to quickly navigate in information technology and to apply their knowledge in practice. The significance of information competence is determined by the transition of Kazakhstan society to the stage of informatization (Fursova et al., 2017). This defines new requirements for human resources, including the ability to adapt to the information flow, work with information, perform information loads, work in the information environment. Avraamova and Verpakhovskaya (2006, p.38) in their research found that employers are interested primarily in the following competencies of graduates: decision-making skills and ability to work in a team, activity, initiative and independence, retraining and training for the acquisition of skills and knowledge. At the same time, higher education in the information society is considered a necessary but insufficient condition for employment. 
Personal qualities are also important in the labor market. When hiring a new employee, company managers often take not those who have the appropriate qualifications, but those specialists who differ in their personal qualities. Employees of the personnel agency "Personnel" indicated that, first, employers pay attention to the behavioral aspect of the applicant. It must conform to the corporate culture of the company and have such qualities as: teamwork, flexibility of thinking, search for non-standard solutions and resistance to stress (Official site of the personnel agency "Personnel").

According to the results of the survey conducted by the authors, it turned out that the very first obstacle to the employment of young people today is "lack of work experience", this factor is important in the life of young graduates. The factor "mismatch of the profession with the desired job" is also an important obstacle for young people. It is known that in our society there are differences in the preferences of young people and the chosen specialties. Due to lack of funds, school graduates cannot get the desired profession, many young people are enrolled in specialties for which state grants are allocated. But, they, in turn, do not want to work on the received specialty. "Lack of acquaintances" is the third factor hindering youth employment. It should be noted that in almost all our studies we noticed that factors such as the lack of "acquaintances", the lack of "financial opportunities" always come to the fore. The survey also raised the issue of "lack of knowledge and qualifications." Let's explain this factor by the following example. For example, when a young specialist visits workplace, he is asked several questions during an interview. The employer asks, "Is there any work experience?", "What can you give our company?", "What are you capable of?". This is understandable, it is beneficial for each employer to get a person who knows the job. At the same time, a big problem lies in the fact that applied knowledge in the preparation of future personnel is not sufficiently developed at the university (Employment of Kazakhstani graduates, 2016). Formal practical training of students causes various problems. 
Employers also noted that they are looking for the right workers with the help of numerous resources (through private labor exchanges, through advertising in the media, etc.). However, most employers also use methods such as personal and corporate communications, personal acquaintances, offers and advice from close acquaintances when selecting personnel. The studies of Kazakhstan sociologists also point to this (Indigigyan, 2014, p. 257-262).

Employers also answered questions about their relationship with higher education institutions. For example, we found that only a minimal (about 10\%) number of employers teach copyright lectures. Some noted that they participate in round tables and conferences held at universities. But at the same time there is no close professional interaction between employers and universities. Kazakhstan sociologists also write about this. They note that between universities and employers there are no effective relations in the field of research, commercial or scientific novelty (Maulsharif \& Bolysbaeva, 2017, p. 29-23).

According to the results of a study conducted by Rating.kz research agency with 72 Kazakhstan and international companies, $64.9 \%$ of respondents noted that Kazakhstan universities do not enter any contacts with employers in the process of training specialists. According to employers, many higher educational institutions in our country cannot resist competition from near and far abroad. Managers and specialists of the company confirmed that high quality of specialists are provided by Russian universities (64.9\%) followed by British universities (44.4\%) and American universities (36.1\%) (Ready to work - why not take?, 2017, p. 35$40)$.

Our study showed that due to the lack of practice and special training, employers do not want to hire young people, namely young people aged 16-24. The problem is that graduates of educational institutions do not have work experience, and without experience it is impossible to find a job.

As for educational institutions, in our opinion, it is necessary to make certain changes to the curricula of the university today, that is, to introduce special courses aimed at professional, psychological and ethical training of the future young 
specialist, which will allow to overcome difficulties in the process of employment among young people. Such specialized courses provide young professionals with comprehensive assistance in their employment. It is also necessary to make the transition from one-time actions to continuous cooperation of enterprises and educational institutions. In the conditions of a post-industrial economy, it is very important to develop social partnership in the process of preparing and assessing the quality of education of specialists with higher, secondary and primary education.

\section{SUMMARY}

According to the study, the problems of youth employment, the existing practice of regulating youth employment is not effective enough. In our opinion, the main way to ensure youth employment is to bring the modern education system in line with the requirements of the labor market. For the uniform integration of youth in the labor market in the education system, a competitive basis must be created for each professional level. There are several ways to solve this problem, including the broad holding of information work among young people, aimed at shaping and enhancing the values of work, popularizing working professions. According to the authors, such measures as the formation of entrepreneurial skills among young people, the organization of professional practice in the framework of the University program, improving the quality of professional education, the use of alternative methods of training and retraining of specialists based on the principles of continuous education can improve the situation.

To achieve the relevant qualities (competencies) of graduates, it is necessary to solve the following tasks:

1. Teaching students' practical skills and job search skills, self-employment.

2. Teaching students' self-presentation and interviewing skills. Employers pay attention not only to the diploma, but to what the students have done in an educational process that is interesting and meaningful for their professional 
development. For this, future specialists need to engage in the development of various projects, participate in contests, grants, and conferences, which will allow developing logical thinking, public speaking skills, and scientific discussion skills. In this regard, it is necessary to make certain changes to the curriculum of the university today, that is, if special courses of professional, psychological and ethical training of the future young specialist were introduced, then, in our opinion, several difficulties in young specialists employing could be overcome.

\section{CONCLUSIONS}

Currently, many unemployed young people who have graduated from a higher education institution, with a diploma in their hands do not have the opportunity to find a job on their own. Most of all this difficult problem is faced by newly qualified specialists. Even if they find a job, the employer does not hire them without work experience.

Thus, we can recommend the following measures to universities and employers to solve this problem:

1. Allocate more academic hours for practical classes in enterprises.

2. Increase the time of practical training, based on the student's profile.

3. Improve computer literacy, especially better master MS Excel, MS PowerPoint and all the basic application features.

4. To increase the level of foreign languages knowledge, as a significant part of employers cooperate with foreign companies. 


\section{REFERENCES}

Avraamova, E. M., \& Verpakhovskaya, Yu. B. (2006). Employers and graduates of universities in the labor market: mutual expectations. Sociological Studies, 4, 37-46. Retrieved from https://www.researchgate.net/ publication/296937954_Employers_and_graduate_students_in_the_labor_ market_Mutual_expectations

Employment of Kazakhstani graduates. (2016). Do not buy mater. High school graduate, 3. Retrieved from http://iac.kz/kk/publishing/ kazakstandyk-zhoo-tulekterinin-zhumyska-ornalasuy [In Russian]

Erikson, R., \& Goldthorpe,J. (2012). The Constant Flux: A Study of Class Mobility in Industrial Societies. Oxford: ClarendonPress.

Fursova, V., Shakirova, A., Nikitina, T., Spirchagova, T., \& Syzdykova, M. (2017). Employment of University Graduates Across the Post-soviet Space: Problems and Solutions (The Example of Kazakhstan). Fournal of History Culture and Art Research, 6(4), 470-478. Retrieved from http:/ / kutaksam. karabuk.edu.tr/index.php/ilk/article/view/1115

Goldthorpe, J. H., Llewellyn, G., \& Glive, P. (1987). Social Mobility and Class Structure in Modern Britain ( $2^{\text {nd }}$ ed.). Oxford: Clarendon Press.

Indigigyan, A. A. (2014). Fluctuation of the labor market in the Republic of Kazakhstan: views of employers (based on quality research). "Strategy" Kazakhstan - 2050": social development of society": material of the 5th Congress of Sociologists of Kazakhstan. -Almaty, 257-262.

Maulsharif, M. \& Bolysbaeva, S. (2017). Interaction of higher education institutions with the labor market and the creation of social partnership. Higher School of Kazakhstan, 2, 29-33. [In Russian]

Official site of the personnel agency "Personnel". http://www.personal. barnaul.ru/? Id_page $=15$ \& id_razd $=70$ 
Ready to work - why not take? (2017). University graduate on a duel with the monster of unemployment. Modern education, 4 (88), 35-40.

Shedenova, N. U. (2008). Sociological analysis of the human capital development of young workers in Kazakhstan companies. Civil society and social progress in the twentieth century. Materials of the second congress of sociologists of Turkic-speaking countries and the third congress of sociologists of Kazakhstan, Almaty, 518-522. 


$$
\text { /15/ }
$$




\section{AN INTEGRATED APPROACH TO THE ORGANIZATION OF KINDERGARTENS TERRITORY}

Olga Vladimirovna Bakurova

Kazan Federal University, Kazan, Russia

Irina Anatolyevna Rysaeva

Kazan Federal University, Kazan, Russia

E-mail: rysira85@mail.ru

Recepción: 05/08/2019 Aceptación: 16/09/2019 Publicación: 23/10/2019

\section{Citación sugerida:}

Bakurova, O.V. y Rysaeva, I.A. (2019). An integrated approach to the organization of kindergartens territory. 3C TIC. Cuadernos de desarrollo aplicados a las TIC. Edición Especial, Octubre 2019, 218-231. doi: https://doi.org/10.17993/3ctic.2019.83-2.218-231

\section{Suggested citation:}

Bakurova, O.V. \& Rysaeva, I.A. (2019). An integrated approach to the organization of kindergartens territory. 3C TIC. Cuadernos de desarrollo aplicados a las TIC. Special Issue, October 2019, 218-231. doi: https://doi.org/10.17993/3ctic.2019.83-2.218-231 


\section{ABSTRACT}

The necessity of considering various factors in the process of improvement of the territory of preschool institutions (PI) is considered. There is an urgent need for an integrated approach, associated with the great importance of healthy and proper education of the growing generation. By authors it is established that the landscape organization of the territory of preschool institutions with a set of planning elements, subordinates to the general plan, despite the obvious appeal, can meet serious obstacles in the form of need of zoning of the site for groups of children of different age. Laying of the "an ecological track" playing an important role in the system of accumulation by each child of personal experience of the correct interaction with the nature can be the decision. By authors it is also shown that the correct planning of the territory of preschool institutions is impossible without competent solution of questions of gardening. It is one of the major moments in all a complex of actions for creation of the comfortable environment.

\section{KEYWORDS}

Preschool, Defensible Space, CPTED, Landscape Gardening, Ecological Pathway. 


\section{INTRODUCTION}

The territory of preschool institutions (PI) - a huge component in the lives of most children. According to NAEYC, more than 5 million people under the age of five attend nurseries in the United States (Herrington \& Studtmann, 1998), and staying in kindergarten is mandatory. In Russia, according to estimates by Forbes Russia (Rogacheva, 2012), there are more than 58000 PI (data 2012); according to (The Ministry of labour of the Russian Federation, 2017), the number of pupils in organizations engaged in programs of preschool education, supervision and care of children rose increased from 2014 to 2016 by $7.8 \%$ (table), over the last 2 years (2016-2017) 788 thousand additional seats were created.

Table 1. Number of pupils in the organizations performing educational activity on educational programs of preschool education, supervision and care of children.

\begin{tabular}{|c|c|c|c|}
\cline { 2 - 4 } & $\mathbf{2 0 1 4}$ & $\mathbf{2 0 1 5}$ & $\mathbf{2 0 1 6}$ \\
\hline $\begin{array}{c}\text { The number of pupils in organizations } \\
\text { engaged in educational activities on } \\
\text { educational programs }\end{array}$ & 6813,6 & 7151,6 & 7342,9 \\
\hline $\begin{array}{c}\text { among them: } \\
\text { in cities and towns }\end{array}$ & 5415,6 & 5693,8 & 5856,3 \\
\hline in rural areas & 1398,0 & 1457,7 & 1486,6 \\
\hline
\end{tabular}

Source: (Rogacheva, 2012).

We analyzed similar indicators in the Republic of Tatarstan; noted that only for the period from 2015 to 2016 the growth of the number of pupils was 2.7\% (211 757 and 217384 people respectively), and in a large city, which is Kazan, the increase is even greater (the number of children attending preschool increased by $12.34 \%$ (Cities and districts of the Republic of Tatarstan, statistical collection, 2016).

Such large-scale figures indicate the special relevance of the task of improvement of the territories of the DDU, creating a healthy and comfortable environment necessary for the competent and full education of the younger generation, taking into account the social, emotional, cognitive and physical development of children. 
Numerous attempts to introduce modern international approaches to the design of kindergartens in the Russian regions are faced with various obstacles that can be objective, for example, a more severe climate and associated severe restrictions in the plant range during landscaping. Implementation barriers (Shmis et al., 2014), which arise as a result of the discrepancy between domestic and Western regulations, have a huge impact.

It is proved ( $\mathrm{Li}$ et al., 2012; Dong et al., 2017) that there is an undeniable relationship between the characteristics of the place and the behavior of the child in landscape spaces, and this applies to children attending different types of institutions - public, private DDU, centers or families for child care (Ansari \& Winsler, 2016).

At the same time, at present a large number of Russian DDU does not have an environmental space that fully meets modern artistic and aesthetic, ergonomic, functional and other requirements.

The undoubted importance of creating "open, flexible and child-oriented space" (in the terminology of (Shmis et al., 2014)) requires consideration of many different factors - climatic, ecological, economic, social, behavioral, et al. We will consider each of them in detail on the example of an average kindergarten in a large city (Kazan, MADOU "the combined kindergarten N. 316 ", "bedroom" area in the city, the size of the occupied land area of 0.99 ha, 245 pupils (Unified state register of legal entities, 2017).

\section{RESULTS AND DISCUSSION}

1. Security issues in difficult conditions of social, natural and environmental disadvantage. At once we will make a reservation that we do not concern various risks, such as possibility of receiving small injuries, stings of insects, food poisoning, sudden emergency situations, undesirable contacts with stray animals, etc., and we focus on other serious problem, namely - possibility of criminal manifestations in relation to children. 
The emergence of in 1972 defensible space theory O. Newman (Newman, 1972) marked the creation a new criminological subdiscipline, which has become called by many «Crime Prevention Through Environmental Design» or CPTED (Steventon, 2012; Warwick, 2009). It has evolved from a theoretical explanation of the relationship between the characteristics of physical space and the criminogenic level, and today it is a global strategy to combat crime and fear of it by developing elements of the environment that prevent the criminal events. It assumes that, in order to ensure an adequate level of security, the facility must be "actively protected, controlled and owned". The last word the authors of (Zen et al., 2014), obviously, interpreted as "having the owner, someone else, not abandoned."

Protection of kindergartens from criminal attacks is a set of measures, the list of which depends not only on the preferences and wishes of the kindergarten management and parents, but is dictated, first, by objective necessity. CPTED defines them as:

- Natural observation, which involves good lighting and visibility of the territory at any time of the day and eliminates the existence of physical environment deficiencies in the form of abandoned areas, "blind" zones, including video equipment. Such closed locations primarily attract possible criminal elements; here we can also include visual control of the street from the windows (the concept of "eyes upon the street" (Jacobs, 1961))

- Proper maintenance and care of the territory. Well-maintained, wellgroomed, comfortable spaces not only attract regular, "authorized" (Zen $e t$ al. , 2014) users, but also repel others, in full accordance with the "theory of broken windows" Wilson-Kelling (Wilson \& Kelling, 1982) and the policy of zero tolerance for any manifestations of deviant behavior (Krayushkina \& Shagabutdinov, 2011)

- Strengthening of the territory and organization of access control, i.e. implementation the principle of "locked gates". Reliable fencing will prevent, on the one hand, unauthorized entry into the territory of 
unauthorized persons through uncontrolled entrances, breaks, manholes, looseness in the fences, and on the other - the escape of children or, alternatively, just running out to the next roadway. Let's refer here the creation of passive access control points with the help of spatial design, which directs people along certain paths, thereby limiting their movement through the territory (Zen et al., 2014). Easily perceived boundaries create a sense of security, "territoriality" (Newman, 1972; Lynch, 2013), i.e. form mechanisms that make space safe in the minds of its inhabitants (Warwick, 2009).

D. Jacobs (Jacobs, 1961) considers the clear demarcation of public and private spaces (in our case, this is the territory of the remote control and the adjacent zone), as well as the increase in pedestrian activity in the adjacent territory to be indispensable conditions for creating a safe environment. In this respect, the situation in this kindergarten is very favorable, as the kindergarten has a secure fence with access control system, is surrounded by high-rise residential buildings, and porches, and the pedestrian traffic is very significant.

Of course, such organization of the protected space system, which implements the concept of situational crime prevention (Krayushkina \& Shagabutdinov, 2011), does not in any way exclude traditional methods of emergency prevention and response (physical protection, panic buttons, emergency call channels a.o.).

2. A huge amount of work is devoted to the organization of the territory, site planning, creating a comfortable gaming and learning environment. Thus, the review (Dong et al., 2017) presents a synthesis of 30 studies from 1985 to 2010 on the interaction of children with the "open environment". The findings suggest that the landscape features affect the physical activity of children. Providing children with the opportunity to learn natural and anthropogenic elements in their environment, despite the possibility of accidental injuries, contributes to the development of cognitive, physical and social skills. 
The debate on the need for outdoor play has been largely driven by a range of phenomena that impede children's play experience in the external environment: rapid urbanization, increased traffic, poorly planned urban environments and pollution, and many other factors , as well as the pressure of educational and play technologies in the indoor environment and lack of awareness of the importance of outdoor play for the development and well-being of children, the formation of motor and cognitive skills, interpersonal attitudes and emotions.

Issues related to the activities of PI in the Russian Federation are regulated by the state educational standard of preschool education (Aziz \& Said, 2012), the content of which affects, including the layout of the site. Design and comfortable conditions of stay of preschool children in kindergarten are closely connected with the correct organization of its territory. The authors (Shmis et al., 2014) note the current trend, the meaning of which is to replace the traditional (institutional) planning scheme on a fundamentally different, the location of the elements of which is subordinated to the idea of the educational landscape (Herrington \& Studtmann, 1998; Shmis et al., 2014).
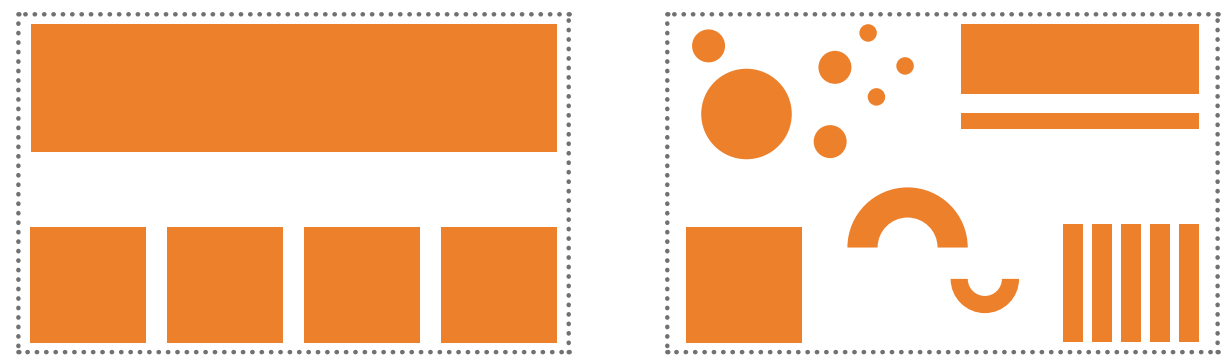

Figure 1. The transition from institutional typology (left) to the typology of educational landscape (right). Source: (Shmis et al., 2014).

It should be noted that the landscape organization of the territory of the PI with a set of planning elements subordinated to the general idea, despite its obvious attractiveness, can meet serious obstacles in the form of the need for zoning the site for groups of children of different ages. The solution may be the laying of an "ecological pathway", which plays an important role in the system of accumulation of each child's personal experience of correct interaction 
with nature. The ecological trail is designed to use walks to communicate with children with their immediate environment, broaden their horizons and improve their health in the fresh air. It promotes environmental education of preschool children, causes a sense of closeness to nature, empathy for all living things, care and respect for the world. Walks along the ecological path develop children's observation and creative activity through games, research, observation, theatrical activities and other activities.

3. Proper planning of the PI territory is impossible without a competent solution of gardening issues. This is one of the most important moments in the whole complex of measures to create a comfortable environment.

The concept of preschool education in nature is not new. Since the first half of the 50-ies of XX century, when Ella Flatau founded the first forest kindergarten in Denmark, the idea begins to spread very quickly and today such institutions are quite common in England, Scotland, USA, Japan, Switzerland, Finland, Norway, Latvia et al. (Hafner, 2002; Robertson, 2008; Miklitz, 2011; Knight, 2013).

However, in the cities we have to be content with trivial landscaping of the territory of the DDU in compliance with certain standards, and if in the 70s of the twentieth century the share of the landscaped area of the PI had to be "as a rule, not less than $50 \%$ of the area of the site", the current decree allows "in the cities in the conditions of the current dense urban development ... reduction of landscaping to $20 \%$ of the area free from development". Thus, we observe a clear and very alarming trend towards a reduction in the area of green areas in the territories of the PI, when the green zone is reduced to $5-10 \%$, and in this regard, it becomes clear concern about the general condition of landings, their quantitative and qualitative characteristics.

On the example of the selected PI, the taxation of plantations was carried out, which showed the good condition of most plants (healthy specimens predominate, having no external signs of damage to the crown and trunk, dead and dying branches). At the same time, it was noted that the trees on the territory grow 
randomly, there is no continuous system of landscaping, and a significant age of the object (more than 30 years) will require soon rejuvenating and recreational activities.

The biodiversity of landings in modern Russian PI is small, and in fact it is the main factor in improving natural habitats, serves to achieve environmental goals: improving the quality of the urban landscape and ensuring a more sustainable and comfortable environment. Plants should be varied in height, leaf color, flowering time, fruit and seed ripening. This selection of trees and shrubs ensures the formation of children's ideas about the diversity of the floral world, develops aesthetic perception. Poor landing sheet leads to the fact that in the game space is not fully implemented subject development environment for children, suffers from the aesthetic side of the created landscape compositions, the child does not receive information about all the richness of the surrounding nature. The meager range of plants not only steals the child emotionally, but also serves as a prerequisite for the possible simultaneous attack of green spaces by age, as well as the spread of diseases throughout the territory.

When selecting plants for landscaping, it is necessary to consider not only their appearance, which determines the artistic value of the created compositions, but also those numerous inherent qualities that have a direct effect on the physiological processes of the human body and constitute the therapeutic value of the natural landscape. Sanitizing properties of plants are determined in the first place, phytoncidity, i.e. the ability to produce and secrete antimicrobial volatile substances, possessing bactericidal action. The plant environment creates a favorable microclimate, reduces dust, gas pollution and noise. The specific nature of the object imposes serious limitations the composition of the used plants, namely, a strict ban on the use of poisonous, prickly and fruiting plants, species that can cause allergy symptoms in the flowering period, plants and foliage which can be cut etc. Not to forget about the orientation of the windows of the group rooms and verandahs and to prevent excessive shading.

The concept of landscaping was based on two main principles. 
The first is the creation of compositions of Continuous decorative" using a bright palette of plants - from the early flowering forsythia europaea to the late autumn maples of the Tatar Acer tataricum and the riverine Acer ginnala.

The second, usually used in the creation of rock gardens and generally rocky gardens-the principle of minimum care, in which, if possible, reduced all agricultural activities: weeding, feeding, pruning, etc.

Considering the above - mentioned restrictions, the plant range was selected for the maximum implementation of all functions of properly organized landscapingenvironmental, protective, decorative, and, finally, educational.

\section{SUMMARY}

1. There is an indisputable interrelation between characteristics of the place and behavior of the child in landscape spaces.

2. The tendency to reduction of the area of the planted trees and shrubs sites in territories of preschool institutions when the green zone is reduced to $5-10 \%$ is revealed.

3. It is defined that the landscape organization of territories of preschool institutions can meet serious obstacles in the form of need of zoning of the site for groups of children of different age.

4. It is established that the biodiversity of landings in modern Russian preschool institutions is small, and it serves achievement of the ecological purposes.

\section{CONCLUSIONS}

The problems concerning the improvement of preschool institutions in the conditions of modern Russia are considered. The emphasis is placed on the need for an integrated approach, including the safety of kindergartens, their planning, landscape gardening, biodiversity conservation of green areas. 


\section{ACKNOWLEDGMENTS}

The work is performed according to the Russian Government Program of Competitive Growth of Kazan Federal University. The author expresses deep gratitude to the staff of the Geography and Cartography Department for the valuable comments made in the preparation of this article.

\section{REFERENCES}

Ansari, A.A., \& Winsler, A. (2016). Kindergarten readiness for low-income and ethnically diverse children attending publicly funded preschool programs in Miami. Early Childhood Research Quarterly, 37, 69-80. doi: https://doi. org/10.1016/j.ecresq.2016.06.002

Aziz, N. F., \& Said, I. (2012). The Trends and Influential Factors of Children's Use of Outdoor Environments. Procedia - Social and Behavioral Sciences, 38, 204212. doi: https://doi.org/10.1016/j.sbspro.2012.03.341

Gities and districts of the Republic of Tatarstan, statistical collection. (2016). Tatarstan, Kazan, p. 292.

Dong, N., Chen, J., \& Zhang, S. (2017). Safety Research of Children's Recreational Space in Shanghai Urban Parks. Procedia Engineering, 198, 612621. doi: https://doi.org/10.1016/j.proeng.2017.07.115

Herrington, S., \& Studtmann, K. (1998). Landscape interventions: new directions for the design of children's outdoor play environments. Landscape and Urban Planning, 42(2-4), 191-205. Retrieved from https://www.deepdyve. $\mathrm{com} / \mathrm{lp} /$ elsevier/landscape-interventions-new-directions-for-the-design-ofchildren-s-6CGcQCOYAf

Jacobs, J. (1961). The Death and Life of Great American Cities. Random House USA Inc. 
Krayushkina, M. M., \& Shagabutdinov, R. S. (2011). The Phenomenology of street crime (the staging problem). Bulletin of Moscow University of the MIA of Russia, 2, 214-221.

Li, Z., Zeng, R., \& Ye, M. (2012). Investigation of the relationship between place characteristics and child behavior in residential landscape spaces: a case study on the Century Sunshine Garden Residential Quarter in Hefei. Frontiers of Architectural Research, 1(2), 186-195. doi: https://doi.org/10.1016/j. foar.2012.03.001

Lynch, K. (2013). The Image of the City. The M. I. T. Press. - 1982. G. 32819. Order of the Ministry of education and science N. 1155 "on approval of the Federal state educational standard of preschool education" dated October 17.

Newman, O. (1972). Defensible space: crime prevention through urban design. N.Y., Macmillan.

Rogacheva, N. (2012). Fardines de infancia en números. Retrieved from https:// www.forbes.ru/svoi-biznes/103220-detskie-sady-v-tsifrah

Shmis, T., Kotnik, J., Ustinova, M. (2014). Creating New Learning Environments: Challenges for Early Childhood Development Architecture and Pedagogy in Russia. Procedia - Social and Behavioral Sciences, 146, 40-46. doi: https://doi.org/10.1016/j.sbspro.2014.08.084

Steventon, G. (2012). Crime Prevention Through Environmental Design. International Encyclopedia of Housing and Home, 280-284. doi: https://doi. org/10.1016/B978-0-08-047163-1.00559-2

The Ministry of labour of the Russian Federation. (2017). State report on the situation of children and families with children in the Russian Federation. date of signing: 28.11.2017

Unified state register of legal entities. (2017). - C. 12. 
Warwick, E. (2009). Defensible Space. International Encyclopedia of Human Geography, 31-38.

Wilson, J. Q., \& Kelling, G. L. (1982). Broken windows: the police and neighborhood safety. Atlantic Monthly, 249(3), 29-38.

Zen, I., Amalina, N., \& Mohamad, A. (2014). Adaptation of Defensible Space Theory for the Enhancement of Kindergarten Landscape. Procedia - Social and Behavioral Sciences, 153, 23-35. doi: https://doi.org/10.1016/j. sbspro.2014.10.037 


$$
\text { /16/ }
$$




\section{FEATURES OF VALUE ORIENTATIONS OF STUDENTS OF FUTURE TEACHERS}

Bakhtiyar Railevich Fakhrutdinov

Kazan Federal University, Kazan, Russia

Rezeda Kamilevna Khurmatullina

Kazan Federal University, Kazan, Russia

Nadezhda Petrovna Yachina

Kazan Federal University, Kazan, Russia

Flera Gabdulbarovna Mukhametzyanova

Kazan Federal University, Kazan, Russia

E-mail: fbakh93@mail.ru

Recepción: 05/08/2019 Aceptación: 16/09/2019 Publicación: 23/10/2019

\section{Gitación sugerida:}

Fakhrutdinov, B.R., Khurmatullina, R.K., Yachina, N.P. y Mukhametzyanova, F.G. (2019). Features of value orientations of students of future teachers. 3C TIC. Cuadernos de desarrollo aplicados a las TIC. Edición Especial, Octubre 2019, 232-245. doi: https://doi. org/10.17993/3ctic.2019.83-2.232-245

\section{Suggested citation:}

Fakhrutdinov, B.R., Khurmatullina, R.K., Yachina, N.P. \& Mukhametzyanova, F.G. (2019). Features of value orientations of students of future teachers. 3C TIC. Cuadernos de desarrollo aplicados a las TIC. Special Issue, October 2019, 232-245. doi: https://doi. org/10.17993/3ctic.2019.83-2.232-245 


\section{ABSTRACT}

The relevance of the study is due to the fact that life priorities, professional preferences of Russian youth have changed, new values have been formed. However, higher education is rarely conducted in accordance with the values and motivations of students. The aim of our study was to determine the structure and content of the values and motivations of student. The study of value orientations of students was conducted using the "polar" questionnaire, revealing the life, material, moral, aesthetic and professional values of students. B. S. Kruglov's method "Determination of formation of value orientations" was also used in our study. The study revealed the structure and content of values and motives of students - future teachers of one of the major universities. The results of the study are applicable for the pedagogical process of higher education.

\section{KEYWORDS}

Values, Motives, Learning Goals Of Students. 


\section{INTRODUCTION}

The transformations taking place in pedagogical education at present have actualized several important tasks that involve the improvement of the content and forms of professional training of teachers. The effectiveness of teacher education does not meet the modern needs of the school. The problem of value orientations and values of modern teachers is widely discussed in psychological and pedagogical science in connection with its relevance for the implementation of personality-oriented approach.

According to Botalova et al. (2016), the value orientation of future teachersresearchers such as "purpose", "means", "knowledge", "attitude", "quality" serve as internal regulators, guides the behavior of future teachers, determines the preference of aspirations and desires, and contribute to the transformation of norms and ideals, personal beliefs and life principle.

The influence of values and motivation on the development of students ' skills to formulate the problem based on critical thinking technology, on the formation of an inclusive competence of the future teacher is noted in a number of works (Akhmadullina et al., 2019).

According to Gurova (2000), and Dobrotvorskaya (2002), the idea that learning and its results is an important step on the path of life is the main value for students. The way to achieve life goals should be broken down into smaller sub-goals with a specific visible result. Then the transition to long-term planning will be painless.

Lidaka, Samusevica, and Striguna (2013) consider that it is very important that students discover the importance of different values in the educational process.

However, the structure and content of values and motivation of students - future teachers was not the subject of scientific analysis.

The aim of our study is to determine the structure and content of the values and motivations of students - future teachers. 


\section{METHODOLOGY}

The study of the content and structure of values and motivation of future teachers was conducted based on a number of theoretical and methodological approaches, including activity, personality-oriented, systemic and technological approaches. The following research methods were used: theoretical methods (analysis, synthesis and generalization of philosophical, cultural, artistic, pedagogical, psychological, methodical literature); empirical methods (questioning, observation, study of educational and creative works of students, interviews, conversations with students and teachers). B. S. Kruglov's method "Determination of formation of value orientations" was applied. The method of content analysis was used to study the motivation of students ' learning.

\section{RESULTS AND DISCUSSION}

The processes of transformation of value systems in modern society affect young people primarily because young people have a special susceptibility, insecurity and social mobility. At the same time, there is a dulling of value orientations among young people, especially among students. The system of value orientations reflects the attitude of students to the surrounding reality, an indicator of the stability of society, being also part of the spiritual sphere, a manifestation of social creativity. In this regard, the problem of study, formation of values of students of pedagogical high school in a reformed society, their structure and content are relevant. However, the understanding of content of values is different.

Values are defined as conscious representations of the subject of value to him, which are revealed by any verbal methods, both sociological and psychological (Leontiev, 1992).

Rokich (2002) defines values as “....abstract ideas, positive or negative, unrelated to a particular object or situation, expressing human beliefs about behaviors and preferred goals" as ...the firm belief that some purpose of individual existence, 
some mode of action is preferable from a personal and social point of view in all situations" (Slotina, 2008). The organization of educational activity is one of the ways of formation of motivation.

Any profession develops its own system of value orientations, professional ethics. Professional values are those personal factors based on which a person makes a choice in favor of certain decisions in the professional field, develops and performs own activities. Professional values provide the necessary motivation, personal socially significant result of all types of professional activity.

One of the ways of formation of motivation is the appropriate organization of educational activities. The content of the educational material is absorbed by students in the learning process. The result of training, development and education of the individual depends on the content of this activity, what parts (individual educational activities) it consists of, how these parts relate to each other, what is their content, what is the structure of educational activities. The success of educational activities also depends on what it is aimed at, what goals students achieve. According to Gabdreev and Smirnov (2008) «the attitude of students to their own activities is largely determined by how the teacher organizes their educational activities, what are its structure and the nature of the presentation of educational material».

Meanwhile, it should be noted that at present, science has not developed a unified approach to the problem of motivation of human behavior, terminology has not been established, and the basic concepts have not been clearly formulated. Markova (1983) defines motivation as "a set of psychological reasons that explain human behavior, its beginning, direction and activity".

Kamenskaya (2003) believes that the motives and values of a student are purchased, are formed during its ontogenetic development. The motive is the pursuit of some rather General target States, types of satisfaction or results. The way to effective learning is through understanding its motivation. Only knowing what motivates the student, what motivates him to work, what motives are the basis of his actions, you can try to develop an effective technology of motivation 
management training. To do this, you need to know how certain motives arise or are caused, how and by what methods the motives can be put into action. Thus, the decisive factor in the effectiveness of training is motivation.

Outstanding psychiatrist, neurologist and psychologist Myasishchev said that the results that a person achieves in his life depend on his intelligence only by 20$30 \%$, and $70-80 \%$ depends on the motives that encourage him to behave in a certain way (Lisovets, 2019).

Educational motivation is a private type of motivation included in educational activities. Educational motivation is determined by a set of factors: first, the educational system, educational institution; second, the organization of the educational process; third, and the subjective characteristics of the student; fourth, the specifics of the discipline.

At the same time, a significant relationship of intellectual development with the success of educational activities has not been proven. A pattern is revealed: "strong" students differ from each other, but not in terms of intelligence, but in strength, quality and type of motivation. Strong students are characterized by internal motivation - mastering the profession at a high level and focus on obtaining professional competencies, and for weak students - external motivation - avoiding condemnation and punishment for poor learning, so the activation of cognitive activity of the student without the development of his cognitive interest is not only difficult, but almost impossible. That is why the cognitive interest of students in the learning process should be systematically excited, developed and strengthened as an important motif of teaching, as a strong personality trait, as a powerful means of educating learning, improving its quality.

Educational activities associated with creativity. However, it is difficult to attract poorly motivated or even unmotivated students to creative activity, since the initial motivation of the student is of great and sometimes crucial importance for the stimulation of creative self-development. 
According to Andreev (2000), among the motives of this specific type of activity can be identified:

1) desire to enjoy recognition and respect in the group;

2) the desire to be strong, healthy, intellectually more developed;

3) the desire to achieve success in school, sports, in life, to take a worthy place in society;

4) the desire to make a career, have a prestigious profession, work;

5) the desire to earn well, to be financially secure;

6) the desire to overcome themselves, improve their abilities;

7) the desire to raise the level of requirements to yourself, get rid of bad habits, etc» (Andreev, 2000).

In addition to the lack of motives, several external and internal reasons can hinder the creative self-development of students:

1) inability to finish the work to the end;

2) lack of ideals;

3) lack of stimulation to the process of training by teachers;

4) lack of peer support;

5) lack of faith in yourself, in your own strength;

6) ignorance of yourself, your strong and weak qualities;

7) lack of literature on self-development;

8) lack of a friend (of a friend) with whom you can consult "the secret". 
The study of the structure of motivations of University students, knowledge of the motives that lead to a activity, allows psychologically sound to solve the problem of increasing the effectiveness of training, as the path to effective learning lies primarily through the understanding of its motivation. Thus, the main factor in improving the effectiveness of training is its motivation.

The study of the system of needs and motives of training students of one of the universities in Russia based on the above concept was conducted by us based on one of the universities in Russia.

Kruglov's method "Determination of formation of value orientations" was applied in the study. The following life goals were ranked on a five-point scale of importance:

1. Autonomy as independence in judgments and estimates:

2. Self-confidence (freedom from internal contradictions, doubts)

3. Material security (no material difficulties in life)

4. Health (physical and mental)

5. Fun (life full of pleasure, fun, enjoyable time)

6. Interesting work

7. Love (spiritual and physical intimacy with a loved one)

8. Freedom as independence in actions and actions

9. Beauty (the experience of the beautiful in nature and art)

10. Good and loyal friends

11. Knowledge (possible expansion of their education, Outlook, intellectual development)

12. Happy family life

13. Creativity (possibility of creative activity)

14. Public recognition (respect of others, collective, companions) 
15. Active, active life

16. Equality (brotherhood, equal opportunities for all).

This method was used to identify the content of the goals (values) of life of 1 st year students, future teachers.

The method of content analysis was used to identify the motives of students' learning. We asked students to write several motives for their studies at the University. However, then we chose only those motives of learning that were in the first place. Working with synonyms made it possible to identify seven main motivations for the training of students of the University. Next, we calculated how many percent of students put this or that motive of learning in the first place.

You can see from Table 1, both at the level of normative ideals (that is, at the level of beliefs) and at the level of individual priorities (that is, in specific actions), for students the most significant are the values of achievement (personal success in accordance with social standards), independence of thought and action, as well as the value of security (stability of society, relations and oneself).

Table 1. The ratio of values of different groups of students.

\begin{tabular}{|c|c|c|c|c|}
\hline \multirow{2}{*}{ Types of values } & \multicolumn{3}{|c|}{ Average index and rank the types of values } \\
\hline Conformity & Level of normative ideals & Level of individual priorities \\
\hline Traditions & 2,69 & 4 & 1,93 & 4 \\
\hline Kindness & 2,25 & 6 & 0,90 & 9 \\
\hline Universalism & 2,45 & 5 & 1,05 & 8 \\
\hline Independence & 1,84 & 9 & 0,74 & 10 \\
\hline Stimulation & 3,95 & 2 & 2,34 & 1 \\
\hline Hedonism & 1,90 & 8 & 1,83 & 5 \\
\hline Progress & 1,65 & 10 & 1,23 & 7 \\
\hline Authority & 4,72 & 1 & 2,13 & 3 \\
\hline Security & 2,05 & 7 & 1,61 & 6 \\
\hline
\end{tabular}

Values such as hedonism (enjoyment), universalism (understanding, tolerance, and protection of the well-being of all people and nature), and stimulation have the least significance at the level of normative ideals. Values such as universalism, tradition and kindness have the least significance at the level of individual 
priorities. Respect and maintenance of customs, acceptance and acceptance of ideas existing in a culture, understanding and tolerance do not take priority in the system of values of modern youth of this sample. Even though at the level of normative ideals these values occupy a priority place in the system of value orientations of students, they are implemented in specific actions and behavior is not always.

\section{SUMMARY}

The study based on the analysis of literary sources justified the need to rely on the psychological approach in teaching students.

The structure of values of students is revealed:

- the group of values in self-expression came to the first place, it is included in the zone of dissatisfaction;

- the group of material values was in second place, it also entered the zone of dissatisfaction;

- the group of values in recognition came in third place; it was in the zone of partial dissatisfaction.

Two groups of values have entered the zone of satisfaction: value in security and value in social relations. This structure of values of students led to the formation of a certain structure of motives of students ' learning.

The rating of motives of training of the surveyed students in high school is defined:

- getting an education in order to find your favorite job;

- obtaining a diploma that would allow you to find a high-paying job;

- education for a decent future;

- training for self-development;

- obtaining knowledge for development in the profession; 
- education with the aim of obtaining personal freedom;

- education as a common behavior.

Two unsatisfied values of students in self-expression and material values, acting in the consciousness of the student together, generate the corresponding motivation of learning and, accordingly, the goals that the student is already aware of. Two unsatisfied values lead to the first place mainly goals related to the material (financial) provision of University graduates in the future. Self-development, development in the profession as the motives of learning pushed to lower places in the ranking of motives. Some students do not realize why they are studying at all ("I am learning because everyone is learning").

\section{CONCLUSIONS}

Therefore, you must create the student's opportunities to meet the valueexpression, engaging them in active and creative scientific activity, and using active learning methods. It is important to stimulate the development of motivation for learning and creative personal self-development of each student in order to improve the efficiency of training students at the University.

It is motivation that is the main tool that will make it possible to increase the level of students ' interest in the educational process, will increase personal scientific creativity. The study of motivation and its formation are two sides of the same process of education of the motivational sphere of the integral personality of the student. The study of educational motivation is necessary to identify the real level and possible prospects, as well as the zone of its immediate impact on the development of each student. In this regard, the results of the study of the process of motivation of learning, showed new processes of the relationship of the content of the educational process and the formation of students ' new goals and needs. 


\section{ACKNOWLEDGEMENTS}

The work is performed according to the Russian Government Program of Competitive Growth of Kazan Federal University.

\section{REFERENCES}

Akhmadullina, R., Valiakhmetova, N., \& Khurmatullina, R. (2019). Students - future teachers development of abilities to formulate a problem on the basis of critical thinking technology. Proceedings of INTCESS 2019-6th International Conference on Education and Social Sciences, 4-6 February 2019- Dubai, U.A.E., 366-372.

Akhmadullina, R., Valiakhmetova, N., \& Khurmatullina, R. (2019). Video cases as a means of forming of motivational component of inclusive competence of students - future teachers. Proceedings of INTCESS 2019-6th International Conference on Education and Social Sciences, 4-6 February 2019-Dubai, U.A.E., 360-365.

Andreev, V. (2000). Pedagogy: Training Course for Creative Self-Development (2 ${ }^{\text {nd }}$ ed.). Kazan.

Botalova, O. B., Osipova, S. V., Asenova, N. S., Kenenbaeva, M. A., Kuderina, A. Y., Zholtaeva, G., ... \& Azanbekova, G. (2016). Value Orientations of Future Teachers-Researchers. International fournal of Environmental and Science Education, 11(17), 10279-10288.

Dobrotvorskaya, S. (2002). Orientation of students to healthy lifestyle through understanding of life goals and values. Pedagogical Education and Science, 1, 5155.

Gabdreev, R., \& Smirnov, A. (2008). Formation of motivation of educational and cognitive activity of University students. Education and self-Development, 10, 227-233. 
Gurova, R. (2000). The Spiritual world of youth in the changing Russia of the XX century (longitudinal sociological research of 1960-2000). The World of Psychology, 4, 147-158.

Kamenskaya, E. (2003). Fundamentals of Psychology. Rostov.

Leontiev, D. (1992). Method of Studying Value Orientations. Moscow.

Lidaka, A., Samusevica, A., \& Striguna, S. (2013). Values actualization in the educational process. 1st Annual International Interdisciplinary Conference, AIIC 2013, 24-26 April, Azores, Portugal - Proceedings, 968-976.

Lisovets, N. (2019). Professional motivation of students as a way to activate learning. Retrieved from http://festival.1 september.ru/articles/598947/

Markova, A. K. (1983). Formation of Learning Motivation in School Age. Moscow.

Slotina, T. (2008). Psychology of Personality: Textbook. St. Petersburg. 


$$
\text { /17/ }
$$




\section{TATAR CULTURE-SPECIFIC WORDS OF THE SEMANTIC FIELD 'ANIMALS' RELATIVE TO ENGLISH}

Gulnara Mohtarovna Nurtdinova

Kazan Federal University, Kazan, Russia

Dilyara Marsovna Sadykova

Kazan Federal University, Kazan, Russia

E-mail: gnurtdinova@bk.ru

Recepción: 05/08/2019 Aceptación: 16/09/2019 Publicación: 23/10/2019

\section{Citación sugerida:}

Nurtdinova, G.M. y Sadykova, D.M. (2019). Tatar culture-specific words of the semantic field 'animals' relative to English. 3C TIC. Cuadernos de desarrollo aplicados a las TIC. Edición Especial, Octubre 2019, 246-257. doi: https://doi.org/10.17993/3ctic.2019.83-2.246-257

Suggested citation:

Nurtdinova, G.M. \& Sadykova, D.M. (2019). Tatar culture-specific words of the semantic field 'animals' relative to English. 3C TIC. Cuadernos de desarrollo aplicados a las TIC. Special Issue, October 2019, 246-257. doi: https://doi.org/10.17993/3ctic.2019.83-2.246-257 


\section{ABSTRACT}

The article is dealing with the problem of semantic gaps, the part of which is a group of culture-specific words. The authors tried to systemize the research by distributing such words into different semantic fields. While comparing the fields on the example of a pair of languages anyone can see the difference in conceptualization of the world picture which is verbalized by the language. The authors researched the Tatar specific concepts relative to English in the field 'Animals'. The results showed that the difference is not so big, and it is proved by the quantity of semantic distance coefficient. It is 6.5 , while the other semantic fields present bigger difference: it is 8.44 for the field 'family', 8.2 for the field 'household objects', 9.93 for the field 'Food' and 11.7 for the field 'Measures'. So far, the biggest difference is in the fields of Religion and Measures. The difference between the Tatar and English fields 'Animals' can be explained by the fact that Tatars were nomads in the past and such an animal like a horse (among 14 words 11 of them are denoting a house age and color that is not presented in English) was important for them. One more argument is the number of Tatar proverbs about a horse. We have found 757 proverbs in the dictionary of Tatar proverbs and sayings.

\section{KEYWORDS}

Language, Linguistics, Semantics, Vocabulary, Lexical Gaps, Semantic Field, Culture-Specific Concepts. 


\section{INTRODUCTION}

The linguists whose names are well known such as Chomsky, Lehrer, Nida and others published a lot of works dedicated to the notion 'non-equivalence'. They believe that such words exist because of difference in culture and denote the objects or phenomena unknown to the people of other culture. One of them, Nida (1964), the founder of the theory of formal and dynamic equivalence supposed that several among civilizations maybe reason difficulties in order that the interpreter. His words are showing that the differences between cultures relate to a culture world picture, which is verbalized by a language and it is proved by Russian researcher S. Ter-minasova. Each language preserves itself over time and represents it to future generations, in his opinion, each language represents the worldview of national culture (Ter-minasova, 2000). Moreover, it is very important to learn a native language to preserve ethnical identity (Babenko, 2015). The differences between cultures are presented in the language in grammar structures, stylistic devices, lexicology and other language levels but we are dealing with lexicology. Non-equivalent words exist in any language presenting the differences between cultures because they present the notions existing in one culture and that are absent in another one. Muscovite scholars Vereshshagin and Kostomarov (1990) supposed which such vocabularies can have the equipollent into tongue A however they cannot have it in the tongue $\mathrm{B}$ (Cvilikaite, 2006). The reasons of existing non-equivalent words have been still researched. As it has been mentioned above, the culture of some ethnic group cannot have the objects or phenomena that are not presented in the culture of other people, so the language does not have the word. For instance, Sabantui is the celebration of Tatar people and the English language does not have the word for it as the English do not have such a holiday. In Tatar there is no word for Easter as Tatars' religion is Islam and there is no such holy celebration. Translation of such words is not difficult because there are some translation technics such as transliteration, transcription and others. But the technics do not present the meaning of the word, so a translator presents the explanation in the footnotes or in the comments. One rather proof of the existing gaps can be described via 
the verity that some objects or phenomena exist in both cultures, but they are not important for one culture and the language does not have the word whereas the object or phenomena exist. For example, the Tatar word kodagy in English has the following meanings: The mother-in-law and the mother-in-law of the bride and groom's parents, grand-sisters, or married relatives do not have the right English equivalence.in English there is no exact equivalent for the mother of the wife or the mother of the husband for the parents of the bride and groom and their relatives Certainly English people have such relatives but the English language does not have the word. It is proved by the results of the research made by one of the authors (Nutrtdinova, 2015), which show that family hierarchy is broader in Tatar culture. For words that cannot easily be equated well, linguists are looking for the right words, and for now, vocabulary gaps, extraneous words, untranslatable words, non-existent words, and so on (Janssen, 2012; Sankaravelayuthan \& Vishwa Vidyapeetha, n.d.). We are dealing with Tatar specific culture notions that are a part of non- equivalent words relative their lacunas in English, namely we are presenting the results of the research in the semantic field 'Animals'. Earlier we researched the groups 'Family and human being environment', 'Religion', 'Food', 'Measures' and 'Household objects'.

\section{METHODOLOGY}

Our study is aimed at the analysis of a semantic field 'Animals'. The words of the field have been selected from Tatar fairy tales published in Tatar. Researchers at the Verona Academy have devised a method that we use. We use equivalence indices in the dictionary of either the target language or the word created by a free word combination in English (Fenenko, 2013). We have studied Tatar, English, electronic dictionaries, and English explanatory dictionaries. In fact, our main obstacle is that the dictionary is not comprehensive and reflects the specific Tataric culture concepts. Finding out that in learning Tataric culture, Englishmen have no reason to misunderstand it and leading to conflicts as the marker of the category ailng/friend (Kalegina et al., 2015). Russian linguist Titov (2002) proposed the method, which allows turning up the difference of the world 
picture conceptualization. In his opinion, when we find a direct equivalent in an explanatory article of a dictionary that yields similar concepts for a word, we must find that both languages determine the semantic context in a similar way. However, in the case when we need a few words to explain the word meaning we can say that the pair language does not have an analogous concept. We also use his formula to calculate the semantic distance coefficient (SDC) showing the difference between semantic fields. SDC $=\mathrm{D}: \mathrm{Q}, \mathrm{D}$ is the summation of every the paroles of the descriptions in the semantic field and $Q$ is the numeral of every the descriptions into the semantic field (Titov, 2002).

\section{RESULTS AND DISCUSSION}

Words that are not present in the vocabulary indicate signs of a slit or a gap that some linguists distinguish between these slots as a random order (Vlachov \& Florin, 1986). Words that do not exist but can be expected to appear seemingly ordinary to be termed random slots, but random slots can be defined as lexical slots and can be realized in a semantic sentence at different levels (Sankaravelayuthan \& Vishwa Vidyapeetha, n.d.). In the opinion of Russian linguist Fenenko (2013) the first step while conducting the research of semantic gaps is to select the words that do not have straightforward equivalents in another language. However, we should exclude proper names. Also, it is necessary at the first stage to choose nouns only as usually specific culture words are expressed per nouns and rarely by adjectives derived from the nouns (Vlachov \& Florin, 1986). It is obvious that it is easier to work with the dictionaries but in the case of the Tatar language (the official language of the Republic of Tatarstan - one of the regions of Russia) we still have a small number of English-Tatar dictionaries and they frequently do not contain non-equivalent words.

The question is what can be referred to semantic gaps. Russian researcher Barchudarov (1975) distributed them in the following groups: proper names, specific culture words and occasional lacunas. We are dealing with specific culture words. One of the ways to solve the problem how to present their meaning is to 
make an Explanatory dictionary of Tatar specific concepts that can be used in developing machine translation process for the language pair Tatar - English. In the opinion of Linguist Rajendran Sankaravelayuthan "A dictionary in such cases provides a mere explanation of the concept encoded by a source language. Unfortunately, such meaning explanations usually are not good in natural language use" (Sankaravelayuthan \& Vishwa Vidyapeetha, n.d.). Because of above mentioned reasons and being Tatar native speakers who speak English we have selected Tatar specific culture concepts from Tatar fairy tales published in Tatar. The choice is diseased per the reality than the fictions were told by residents of Tatar villages who spoke natural language and later the tales were published with comments of the researchers. We have distributed specific-culture words in a few semantic fields, one of them is 'Animals'. Fenenko (2013) believes that while comparing smaller fields anyone can easily see the difference in conceptualization of word picture verbalized by the language.

In this essay, we attempt to provide a draft of an English explanatory passage for the semantic context of Tataric. The string is small, 14 word only while the field for kinship has 42 words, the field for food has 16 words, the field for religion has 25 words, the field for measures has 16 words and the field household objects has 44 words. We think that because of climate conditions English and Tatar people have the same animals but there is some difference due to different historical conditions. English people live on the island and have a settled way of life. Tatar people were nomads and lived mostly in prairies and woodlands, so a horse was very important for them in the past. Among 14 words referring to the field 'animal' found by us in Tatar fairy tales 11 words denoted horses of different ages (taj, kolyn, kolkai, baytal) and colors (kyzgylt, akbuz, zhiran), etc. It is also proved by the fact that in the dictionary of Tatar proverbs (3 volumes) we have found 757 proverbs dedicated to a horse. 
In fact, we bring up an explanatory dictionary draft, and finally provide the necessary word modifications to explain the meaning of the word. As it has been mentioned above, in the case we need a few words to explain the word meaning we may tell than the mate tongue does not have a similar sense. The rather mots we demand the imperial is the interval amid the senses.

\section{Animals}

Kyzgylt - adj. (the color of a horse coat) chestnut, red and shot with pink 13.

Yelky - n. a herd horse breeding specially for meal 9.

Kashka - n. (for an animal) horse with a blaze 8 .

Taj - n. a foal up to three years old 8 . Kolyn - n. a foal up to one year old 8.

Kyrykmysh taj - a foal from one to two years old 8 .
Argamak - n. Central Asian breed of saddle horse 7 .

Zhanvar - n. predatory animals, beasts of prey 6 .

Akbuz - adj. white and grey color 5 .

Kolkai - n. a yearling foal 5 .

Kiek - n. fowl, game, game animals 5.

Baytal - n. barren mare 3 .

Zhiran - adj. chestnut, red 3.

Zhanlek $-\mathrm{n}$. wild animals 3 .

Table 1. Semantic Distance Coefficient (SDC) for Semantic Field Animals.

\begin{tabular}{|c|c|c|}
\hline $\begin{array}{c}\text { Number of Explanatory } \\
\text { Words }\end{array}$ & $\begin{array}{c}\text { Number of specific culture } \\
\text { words }\end{array}$ & Total number of words \\
\hline 3 & 3 & 9 \\
\hline 5 & 3 & 15 \\
\hline 6 & 1 & 6 \\
\hline 7 & 1 & 7 \\
\hline 8 & 4 & 32 \\
\hline 9 & 1 & 9 \\
\hline 13 & 1 & 13 \\
\hline & $\mathbf{Q = 1 4}$ & $\mathbf{D = 9 1}$ \\
\hline & & SDC= D/Q=90/14=6.5 \\
\hline
\end{tabular}


In the first column we presented the numeral of the mots we demand against illustrate the purpose. The second column shows how many words we have selected with the same number of words to explain the meaning. We found 3 words that need 3 words to describe the meaning, 3 words that need 5 words, 1 word that need 6 words, etc. The third column shows the total number of words, which we are getting by multiplying the figures of the first and the second columns.

We used the formula SDC =D/Q proposed by Titov (Kalegina et al., 2015) (where $\mathrm{D}$ is a total number of words and $\mathrm{Q}$ is a number of specific culture words) to calculate the semantic distance coefficient, which is 6.5. In average we need 6.5 words to explain the meaning of the words for the field 'Animals'.

\section{SUMMARY}

We suppose that the most confusing fact for English people is the one that Tatars breed horses for eating (Yelky) which is natural for people who were nomads in the past. Also it should be taken into consideration that the colors and ages of horses in Tatar are also different from English. Three words that do not have the straightforward equivalents are denoting wild animals: zhanvar, kiek, zhanlek. In Tatar there are special words to single out wild animals which are presented in English by a few words. So SDC for the field Animals is 6.5 as opposed to 8.2 for the field Household objects, 8.44 for the field Family, 12.44 for the field Religion, 9.93 for Food, 11.7 for the field Measures.

\section{CONCLUSION}

The semantic gap has created profound problems for linguists that have led to various definitions and names, as discussed above: lexical gaps, non-lexical words, untranslatable words, non-existent words, and so on. The problem is not easy to solve as the gaps can exist in language A relative to the language $\mathrm{B}$, but they are not presented relative to the language $\mathrm{C}$. It is obvious that it is necessary 
to research them by studying a pair of specific languages. Many researchers tried to systemize the methods and one of the most effective methods is the method of semantic fields. While comparing the fields anyone can easily see the difference in conceptualization of the word picture which is verbalized by the language. Moreover, the method helps to simplify the process of making an expositive glossary of specific civilization meanings besides supports the development of machine translation. What is more important research results can show the difference in culture world picture and prevent conflicts into the proceeding of Intercultural relevance.

\section{ACKNOWLEDGEMENTS}

The work is performed according to the Russian Government Program of Competitive Growth of Kazan Federal University.

\section{REFERENCES}

Babenko, O. V. (2015). Language as a basic feature of ethnos uniting within the conditions of modern challenges. Fournal of Language and Literature, 6(3), 168170. doi: https://doi.org/10.7813/j11.2015/6-3/38

Barchudarov, L. G. (1975). Language and Translation. Moscow: Mezdunarodnye Otnosheniya.

Chomsky, N. (1965). Aspects of the Theory of Syntax. Cambridge: The MIT Press.

Gvilikaite, J. (2006). Lexical Gaps. Retrieved from http://donelaitis.vdu.lt/ publikacijos/dd45_cvilikaite.pdf

Fenenko, N. A. (2013). French Realias in the Aspect of the Theory Iof Renomination. Voronezh, Russia: Izdatelstvo Voronezhskogo Universiteta.

Janssen, M. (2012). Lexical gaps. Retrieved from http://maarten.janssenweb. net/Papers/2012-lg-janssen.pdf 
Kalegina, T. E., Takhtarova, S. S., \& Zaglyadkina, T. Y. (2015). Denglish and Franglais in the framework of the modern European linguistic landscape. Journal of Language and Literature, 6(3), 195-198. Retrieved from http://dspace.kpfu.ru/xmlui/bitstream/handle/ net/142405/SCOPUS 20780303 - 2015 -6-3-SID 84959051476 -a 1. pdf;jsessionid=E97E1A2175E20B5E97CF759667A96BFB? sequence $=-1$

Nida, E. (1964). Toward A Science of Translating. Leiden: E. J. Brill.

Nutrtdinova, G. (2015). Fournal of Sustainable Development, 4, 169-176.

Sankaravelayuthan, R., \& Vishwa Vidyapeetha, A. (n.d.). Lexical gaps in the vocabulary structure of a language. Retrieved from https://www.researchgate.net/ publication/330141511_Lexical_gaps_in_the_vocabulary_structure_of_a_ language

Ter-minasova, S. (2000). Language and Intercultural Communication. Moscow: Slovo.

Titov, V. (2002). General Quantitative Lexicology of Romanic Languages. Voronezh. Russia: Izdatelstvo Voronezhskogo Universiteta.

Vereshshagin, E. M., \& Kostomarov, V. G. (1990). The Language and the Culture. Moscow.

Vlachov, S., \& Florin, S. (1986). Lexical Gaps in Translation. Moscow, Russia: Vysshaya Shkola. 
Edición Especial Special Issue Octubre 2019 DOI: https://doi.org/10.17993/3ctic.2019.83-2.246-257 


$$
\text { /18/ }
$$




\title{
THE FINTECH AND ISLAMIC FINANCE SYNTHESIS IN THE MODERN WORLD
}

\author{
Elvira Ildarovna Bulatova \\ $\mathrm{PhD}$ in Economics, Assistant Professor of Banking Department of the \\ Institute of Management, Economy and Finance, Kazan Federal University, \\ Kazan, Russia \\ E-mail: bulatovaei@yandex.ru
}

Ekaterina Alekseevna Potapova

Graduate student of Banking Department of the Institute of Management, Economy and Finance, Kazan Federal University, Kazan, Russia E-mail: potapovakate@gmail.com

Regina Andreevna Fathutdinova Master of the Institute of Management, Economy and Finance, Kazan Federal University, Kazan, Russia E-mail: yumio.moe@yandex.ru

Ruslan Ghirgishanovich Yandiev Master of the Institute of Management, Economy and Finance, Kazan Federal University, Kazan, Russia E-mail: ryandiev@gmail.com

Recepción: 05/08/2019 Aceptación: 16/09/2019 Publicación: 23/10/2019

\section{Citación sugerida:}

Bulatova, E.I., Potapova, E.A., Fathutdinova, R.A., y Yandiev, R.C. (2019). The fintech and islamic finance synthesis in the modern world. 3C TIC. Cuadernos de desarrollo aplicados a las TIC. Edición Especial, Octubre 2019, 258-273. doi: https://doi. org/10.17993/3ctic.2019.83-2.258-273

Suggested citation:

Bulatova, E.I., Potapova, E.A., Fathutdinova, R.A., \& Yandiev, R.C. (2019). The fintech and islamic finance synthesis in the modern world. 3C TIC. Cuadernos de desarrollo aplicados a las TIC. Special Issue, October 2019, 258-273. doi: https://doi. org/10.17993/3ctic.2019.83-2.258-273 


\section{ABSTRACT}

The article discusses the economic prerequisites for the effective growth of Islamic finance in modern conditions, analyzes the existing definitions of Islamic finance and banking and financial technologies, which served as the basis for the formation of a new definition of digital Islamic banking.

The authors carried out a simulation of the influence of the FinTech industry on the development of Islamic finance and formed the basic prerequisites for further sustainable growth in this area. The new theoretical definition is a synthesis of two systems that can be used later to identify digital tools that can be applied within the framework of Islamic finance. No less important in this aspect is the preservation of Sharia norms.

The modeling becomes an evidence base for the further use and expansion of Fintech tools in Islamic banking and Islamic finance in general. This aspect is also confirmed by the development of the Islamic Fintech Ecosystem and Islamic Fintech companies.

\section{KEYWORDS}

Islamic finance, Islamic banking, Financial technologies, Fintech, Economic and mathematical modeling, Digitalization, Islamic fintech, Digital islamic banking. 


\section{INTRODUCTION}

Today, the development of Islamic finance, expands the possibilities of the financial interrelationship between participants at the world level, and not only within the framework of the Islamic world. Nowadays, the rapid development of digital technologies within the pecuniary section actualizes the use of new tools in the countries of the Islamic world (Demyanova, 2017).

Today FinTech is gaining momentum in such areas as online lending, money transfers, credit ratings, crowdfunding, blockchain and cryptocurrency. In addition, some companies develop robot consultants who can offer solutions for deposits and lending, based on the wishes of customers, and taking into account all kinds of risks (Li et al., 2009).

For this purpose, this economic model was designed at define the strike of the development of pecuniary technologies upon the volume of Islamic finance (Bulatova, Zakhmatovm, Aliakberova, \& Koczar, 2016).

\section{METHODOLOGY}

The article provides a structural-dynamic analysis of GDP for the four countries and Dow Jones to determine more efficient cheap pickup into the nations of the Islamic world. qua in short of the lysis, the maners of correlation and regression analysis were applied in order to build a forecast of Islamic banking assets with the influence of financial technology factors on it (Fintech). The following methods were also used: statistical, graphical methods of analysis, tabulation, generalization and systematization, as well as methods of scientific knowledge. 


\section{RESULTS AND DISCUSSION}

In the context of global financial and geopolitical instability, a constant uncontrolled flow of capital between financial markets caused by speculative actions, factors arise to slow down the development of the national and world economy, such as price instability, high cost of borrowed funds, and inefficient redistribution of monetary resources (Patrutiu-Baltes, 2016).

In 2014-2018, despite the economic crisis in general, it is observed that qua in short of the reduction into petroleum values, not only the growth of assets of banks in the Islamic world, but also profitability is declining, which leads to a potential merger or takeover of financial institutions. However, to continue confronting crisis situations Islamic financial institutions need to turn to innovations and modern technologies used in the financial world (Jamaldeen, n.d.).

Most oil-producing countries have a stable legal structure that allows for the effective use of Islamic banking structures alongside traditional institutions. If the broader banking sector suffers from lower oil prices, it is expected that policies of both legal and regulatory nature will be formulated for the banking sector and not just for ordinary or Islamic banks. On the other hand, Islamic banks are inherently risk-averse. Given their ban on gambling, uncertainty and speculation, they are perhaps better protected to protect themselves from high risks and unstable investments (Islami Bank Bangladesh Limited, n.d.; Bloomberg, 2019; Lim, 2019).

While the Islamic finance sector shows a more stable performance during crisis turmoil in the global financial market in the GDP growth rate at constant prices in comparison to leading economies of the world (Figure 1). 

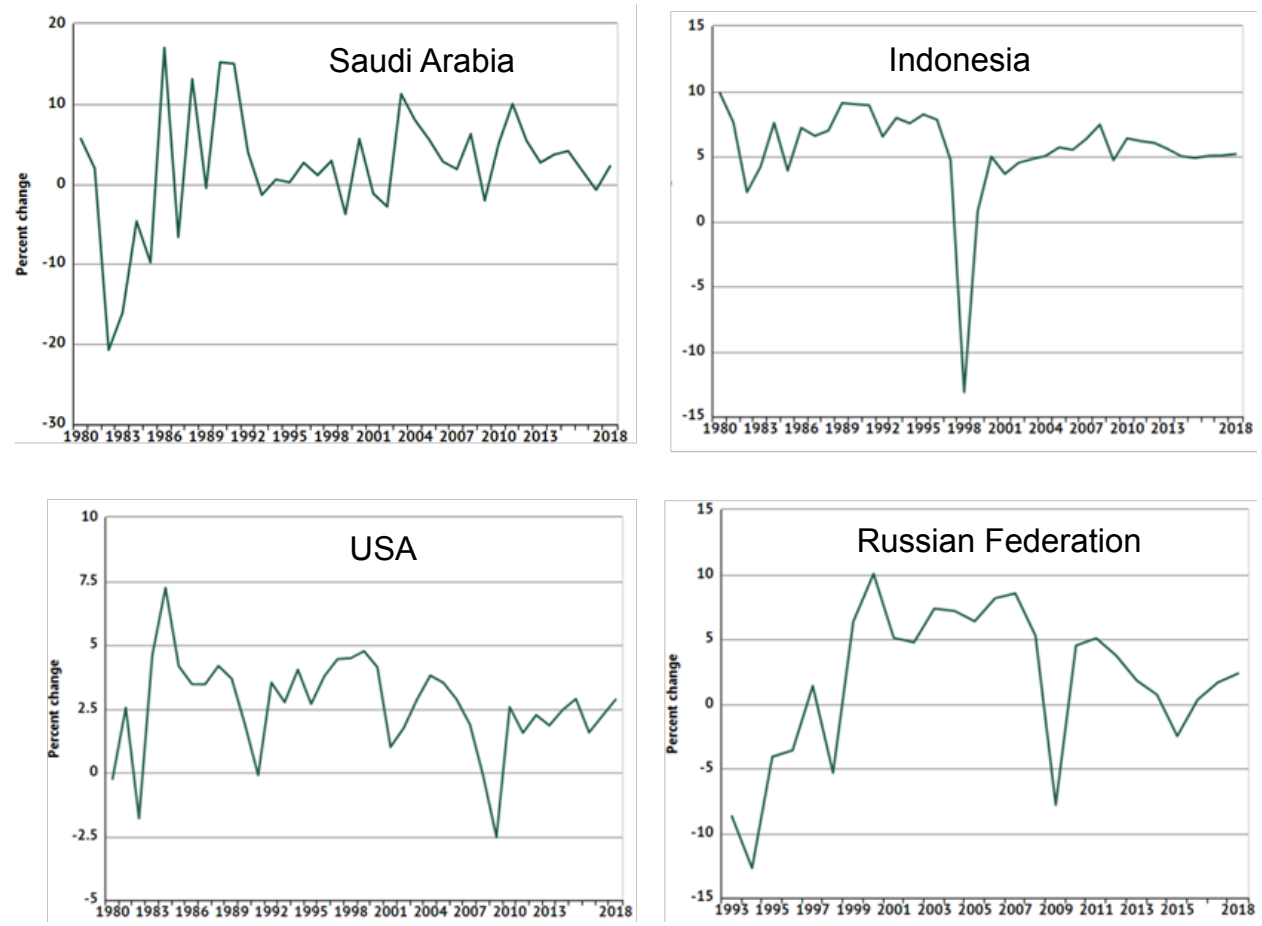

Figure 1. Comparison of GDP of countries in the world. Source: (World Data Atlas, n.d.)

In addition, the GDP growth rate showed positive dynamics, the index of Dow Jones from the Islamic world than USA rate (Figure 2).

Comparative characteristics of the Dow Jones indexes of the United States of America and the Islamic world showed that:

- The Dow Jones USA index for 10 years rose by $8.83 \%$

- The Dow Jones Islamic Market index rose by 16.47 in 10 years $\%$. 


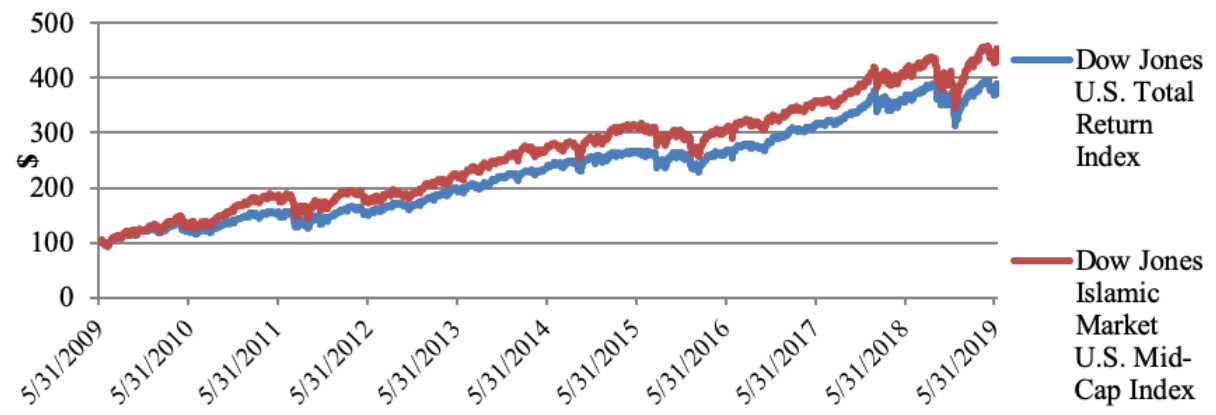

Figure 2. Comparison of the Dow Jones indices of the USA and the Islamic world. Source: (S\&P Dow Jones Indices, n.d.).

This structural-dynamic analysis shows a more sustainable growth of Islamic finance in comparison with western countries. Thus, an important aspect of the budgetary extension of the nations of the Islamic universe may be the efficacy of digital tools in the industry FinTech.

There are different interpretations in the definition of financial, technology and Islamic finance, the main of which are presented in Table 1.

Table 1. The financial technologies and Islamic finance definitions and interpretation.

\begin{tabular}{|c|c|c|}
\hline Definition & \multicolumn{1}{|c|}{ Interpretation } & $\begin{array}{c}\text { Supporters of } \\
\text { interpretation }\end{array}$ \\
\hline $\begin{array}{c}\text { Digital innovative financial services solutions } \\
\text { provided and used by companies on a technology } \\
\text { platform, competing / cooperating with financial } \\
\text { institutions. }\end{array}$ & E.A. Demianova \\
\hline $\begin{array}{c}\text { Financial } \\
\text { Technology }\end{array}$ & $\begin{array}{c}\text { It is strangely surprising how academic literature } \\
\text { has neglected the field despite the marvelous } \\
\text { impact of fiscal technology on the fiscal favors } \\
\text { industry. }\end{array}$ & Shim and Shin, 2016 \\
\hline & $\begin{array}{c}\text { It is driven by variations in the ecosystem } \\
\text { and contesting structure of favors and the } \\
\text { transformation of craft running, fiscal technology. }\end{array}$ & Deloitte, 2016 \\
\hline
\end{tabular}




\begin{tabular}{|c|c|c|}
\hline Definition & Interpretation & $\begin{array}{l}\text { Supporters of } \\
\text { interpretation }\end{array}$ \\
\hline \multirow{3}{*}{ Islamic finance } & $\begin{array}{l}\text { An ethical financial and investment sector serving } \\
\text { the needs of the real economy, which are based } \\
\text { on the principles of legality, justice, equality and } \\
\text { distribution. The basic economic principle is a ban } \\
\text { on usury }\end{array}$ & E. A. Baydaulet \\
\hline & $\begin{array}{l}\text { Islamic banking - The financial order, graded on } \\
\text { the origins of Islamic law and ushered by Islamic } \\
\text { economics, is called non-profit banking. }\end{array}$ & Sandra Lim \\
\hline & $\begin{array}{l}\text { It is Shari'a law that specifies how to finance it, } \\
\text { which is a financial system. }\end{array}$ & Faleel Jamaldeen \\
\hline Islamic banking & $\begin{array}{l}\text { Adherence to the Shari'a can create a kind of } \\
\text { Islamic banking system that can be used to develop } \\
\text { financial resources through its feasible usage } \\
\text { through the Islamic economy. }\end{array}$ & ING GROUP, 2017 \\
\hline \multirow[t]{2}{*}{ Islamic banking } & $\begin{array}{l}\text { Islamic Banking With the ethics of the Islamic value } \\
\text { system, essentially a normative concept is also } \\
\text { described as overseas banking. }\end{array}$ & Dr. Ziauddin Ahmed \\
\hline & $\begin{array}{l}\text { Islamic banking is a finance management system } \\
\text { that is based on the Islamic rules }\end{array}$ & Junaid Akhtar Abbasi \\
\hline \multirow[t]{2}{*}{ Digitalization } & $\begin{array}{c}\text { Digitizing comparability data encryption and } \\
\text { encryption is called digitalization, which allows } \\
\text { computers to supply, procedure, and broadcast } \\
\text { such data. }\end{array}$ & Jason Bloomberg \\
\hline & $\begin{array}{c}\text { With the integration of digital technologies } \\
\text { everything that can be digitized can be termed } \\
\text { digital. }\end{array}$ & Mohamed El-Shimy \\
\hline
\end{tabular}

Presents interpretations reveal the essence of Islamic finance and financial technologies as two unrelated directions. However, with the development and application of tools for the FinTech industry in the Islamic world is important for the formation of this definition, such as digital Islamic banking.

Digital Islamic banking is a technology of providing Islamic banking products and services through online services using tools FinTech industry.

An important aspect of the formation of the new definition is a close relationship between Islamic finance and Islamic banking since banks are an important element of the financial system. 
Considering the influx of FinTech industry invoices upon the enlargement of Islamic banking as an element of the financial system, economic and mathematical modeling was carried out. The indicators to be modeled are presented in Table 2.

Table 2. Input data for modulation.

\begin{tabular}{|c|c|c|c|c|c|c|c|}
\hline Years & $\begin{array}{c}\text { Islamic } \\
\text { Banking } \\
\text { Assets } \\
\text { (Billion USD) }\end{array}$ & $\begin{array}{l}\text { Total } \\
\text { investment } \\
\text { activity in } \\
\text { FinTech } \\
\text { (Capital } \\
\text { invested } \\
\text { (\$B)) }\end{array}$ & $\begin{array}{c}\text { Total } \\
\text { investment } \\
\text { activity in } \\
\text { FinTech } \\
\text { (Deal count) }\end{array}$ & $\begin{array}{l}\text { Global } \\
\text { venture } \\
\text { capital } \\
\text { activity in } \\
\text { FinTech with } \\
\text { corporate } \\
\text { participation } \\
\text { (Capital } \\
\text { invested } \\
\text { (\$B)) }\end{array}$ & $\begin{array}{l}\text { Global } \\
\text { venture } \\
\text { capital } \\
\text { activity in } \\
\text { FinTech with } \\
\text { corporate } \\
\text { participation } \\
\text { (Deal count) }\end{array}$ & $\begin{array}{c}\text { Global private } \\
\text { investment in } \\
\text { blockchain \& } \\
\text { cryptocurrency } \\
\text { (Capital } \\
\text { invested (\$B)) }\end{array}$ & $\begin{array}{l}\text { Global private } \\
\text { investment in } \\
\text { blockchain \& } \\
\text { cryptocurrency } \\
\text { (Deal count) }\end{array}$ \\
\hline & $\mathbf{Y}$ & $\mathrm{X} 1$ & X2 & X3 & X4 & $\times 5$ & $\times 6$ \\
\hline 2013 & 1565 & 18,9 & 1,132 & 0,8 & 102 & 0,2 & 69 \\
\hline 2014 & 1445 & 45,4 & 1,543 & 2,5 & 137 & 0,7 & 144 \\
\hline 2015 & 1604 & 67,1 & 1,925 & 8,5 & 225 & 0,5 & 134 \\
\hline 2016 & 1675 & 63,4 & 1,893 & 11,6 & 287 & 0,6 & 159 \\
\hline 2017 & 1721 & 50,8 & 2,165 & 10,3 & 327 & 4,8 & 218 \\
\hline $2018^{*}$ & 1809 & 111,8 & 2,196 & 23,1 & 357 & 4,5 & 494 \\
\hline
\end{tabular}

Source: (Pollari \& Ruddenklau, 2018).

Initially, a correlation matrix is created to specify the grade of penetration of the selected $\mathrm{X}$ on the studied $\mathrm{Y}$ (Table 3).

Table 3. Correlation matrix.

\begin{tabular}{|c|c|c|c|c|c|c|c|}
\hline & $\mathbf{Y}$ & $\mathrm{X} 1$ & $\mathrm{X} 2$ & $\mathrm{X3}$ & $\mathrm{X} 4$ & $\mathrm{X} 5$ & $\mathrm{X} 6$ \\
\hline $\mathbf{Y}$ & 1 & & & & & & \\
\hline $\mathrm{X} 1$ & 0,704093 & 1 & & & & & \\
\hline $\mathrm{X} 2$ & 0,755271 & 0,793208 & 1 & & & & \\
\hline $\mathrm{X} 3$ & 0,886938 & 0,946588 & 0,827307 & 1 & & & \\
\hline$X 4$ & 0,902747 & 0,786041 & 0,949344 & 0,900661 & 1 & & \\
\hline$\times 5$ & 0,758852 & 0,546898 & 0,740252 & 0,696453 & 0,787007 & 1 & \\
\hline $\mathrm{X} 6$ & 0,761314 & 0,893595 & 0,695939 & 0,924876 & 0,758369 & 0,774287 & 1 \\
\hline
\end{tabular}

The correlation matrix shows the level of influence of the selected factors on the object of study. According to it, the factors X1-X6 have the values of the correlation coefficients greater than 0.5 and are accepted for the study, however, among them, there is a multi-linearity above 0.7 . So, by correlation, multi- 
linearity observed in X1 with all factors except X5. For expediency of carrying out further modeling, $\mathrm{X} 5$ is accepted to the regression analysis as not correlating with $\mathrm{X} 1$ and $\mathrm{X} 4$, as an indicator with the greatest correlation with $\mathrm{Y}$.

The conducted regression analysis showed that almost $82,11 \%$ of Islamic Banking Assets depends on the formation and change of X4 and X5 values (Table 4). Fisher statistics characterize the significance of the regression model.

Table 4. Regression analysis of the economic model.

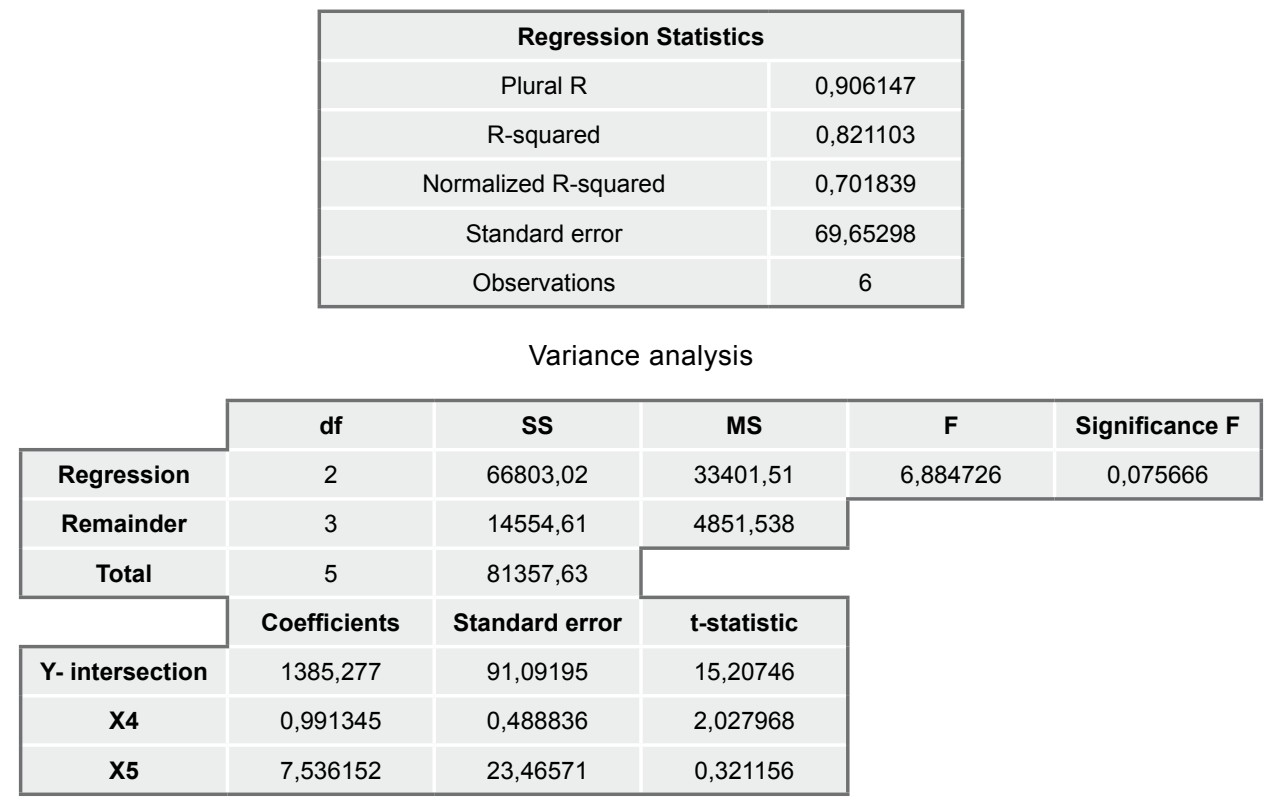

To forecast the value of Islamic banking assets, the regression equation (Formula $1)$ :

$$
\mathrm{Y}=1385,277+0,9914 * \mathrm{X} 4+7,5362 * \mathrm{X} 5
$$

After conducting a point forecast X4 and X5 and adding connected values in the regression equation (Formula 1), a forecast of the value of Islamic Banking Assets was made if it would be influenced only by X4 and X5. The point forecast is carried out through the determination of the trend line for each of the factors 
$\mathrm{X} 4$ and $\mathrm{X} 5$ for 1 forward forecast period with the conclusion of the regression equation. The forecast period number is supplied instead of the unknown $\mathrm{X}$ value.

Further, according to Formula 1, instead of the unknown X4 and X5, their predicted values for 2019-2021 are added to calculate the value of Y (Figure 3).

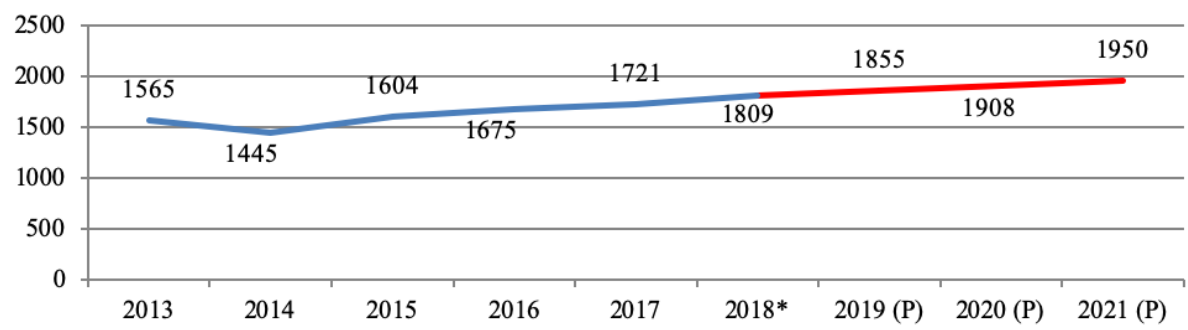

Figure 3. Forecast volume of Islamic Banking Assets the influence of factors $X 4$ and $X 5$, billion USD.

Thus, the impact on the Islamic banking Assets indicators such as global venture capital activity in FinTech with corporate participation (Deal count) (X4) and global private investment in blockchain \& cryptocurrency (Capital invested (\$B)) (X5) by 2021, may lead to an increase in the indicator to almost $\$ 2$ trillion.

An important aspect of the analysis is that Islamic banks are in a better position than traditional banks because they are a rapidly developing area of Islamic Finance. With enough investment in financial system participants in FinTech, can lead to more significant growth of the economy as a whole.

The most promising are such tools as crowdfunding, P2P lending, and digital technology management. The only factor that distinguishes the usual FinTech from the Islamic one is the need to observe the principles of Sharia.

Using the experience of upgrading existing financial instruments into products such as Murabaha and Musharaka that meet Sharia standards, it becomes possible to apply a similar approach to FinTech instruments. Combining safe investment and social responsibility with innovation and efficient use of available tools, Islamic Finance can use any modern financial instruments and use them effectively. 
For example, Islamic fiscal technology has solved astonishingly, with the appearing universal Islamic fiscal technology order fireplace stiffly on P2P financing. There is a basilar fireplace on peer-to-peer financing to address the remonstrative demand for making Shariah-compliant financing more available for commerce and consumers, but many slots stay self-relative to demand and market potential.

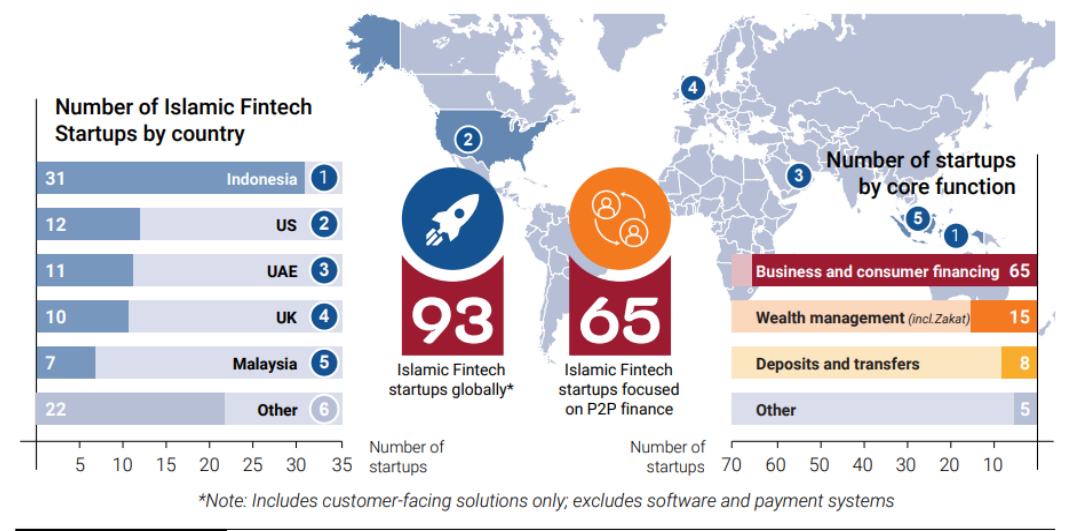

Key takeaway:

There is an emerging global Islamic Fintech ecosystem, with a strong focus to date on P2P finance.

Figure 4. Islamic FinTech Ecosystem. Source: (Islamic Fintech Report, 2018).

\section{CONCLUSION}

The previously described model of the influence of FinTech factors on Islamic banking Assets is proved in practice. To date, there are already dualistic companies that use FinTech and Islamic Finance at the same time (Table 5) (Firmansyah \& Anwar, 2019).

For example, InvestProperti.id is a sharia crowdfunding platform in Indonesia focusing on property investment. The vision of this firm is to provide ease to everyone to invest in property. With a tiny number of employees, since its establishment, InvestProperti.id is progressive as it has served 189 customers. 
Table 5. The profile of participating Islamic FinTech firms.

\begin{tabular}{|c|c|c|c|c|c|c|}
\hline No & $\begin{array}{c}\text { Name of the Fintech } \\
\text { firm }\end{array}$ & Headquarter & $\begin{array}{l}\text { The services } \\
\text { provided }\end{array}$ & $\begin{array}{c}\text { Year of } \\
\text { establishment }\end{array}$ & $\begin{array}{l}\text { Number of } \\
\text { employees }\end{array}$ & $\begin{array}{l}\text { Number of } \\
\text { customers }\end{array}$ \\
\hline 1 & $\begin{array}{l}\text { InvesProperti.id } \\
\text { (PT. Berkah Inovasi } \\
\text { Nusantara 2018) }\end{array}$ & Indonesia & $\begin{array}{l}\text { Crowdfunding } \\
\text { pltaform to } \\
\text { make property } \\
\text { investment } \\
\text { accessible to } \\
\text { everyone }\end{array}$ & 2018 & 3 & 189 \\
\hline 2 & $\begin{array}{l}\text { GOOLIVE (PT Sinergi } \\
\text { Inti Berkah Investama) }\end{array}$ & Indonesia & $\begin{array}{l}\text { Peer to peer } \\
\text { lending }\end{array}$ & 2018 & 5 & 67 \\
\hline 3 & $\begin{array}{c}\text { ALAMI Teknologi } \\
\text { Sharia }\end{array}$ & Indonesia & $\begin{array}{l}\text { Other financial } \\
\text { services } \\
\text { (Fintech } \\
\text { Aggregator) }\end{array}$ & 2017 & 9 & 9 \\
\hline 4 & $\begin{array}{c}\text { Syarfi (PT Syarfi } \\
\text { Teknologi Finansial) }\end{array}$ & Indonesia & $\begin{array}{l}\text { Peer to peer } \\
\text { lending }\end{array}$ & 2017 & 6 & \\
\hline 5 & $\begin{array}{l}\text { Qasir (PT Solusi } \\
\text { Teknologi Niaga) }\end{array}$ & Indonesia & $\begin{array}{l}\text { Application of } \\
\text { Point of Sales } \\
\text { (PoS) }\end{array}$ & 2015 & 44 & 5,000 \\
\hline 6 & $\begin{array}{c}\text { EthisCrowd (Ethis Pte } \\
\text { Ltd) }\end{array}$ & Singapore & $\begin{array}{l}\text { Real estate } \\
\text { investment }\end{array}$ & 2015 & 15 & 25,000 \\
\hline
\end{tabular}

Source: (Firmansyah \& Anwar, 2019).

Despite the slowdown in economic growth due to falling oil prices, the Islamic financial industry continues to evolve and strive for the same indicators. This is facilitated by "revolutionary" financial technology. The use of FinTech tools allows us to stimulate the economic growth of all countries of the world and not just Islamic ones.

On this basis, a new theoretical definition was formed, combining both aspects of the digital economy and Islamic finance. With the further formation of new tools that meet Shariah standards, but which are FinTech tools, the new conceptual apparatus can serve as a basis for a more precise definition of certain aspects of the Islamic FinTech industry.

The relevance of the application and development of the FinTech industry in the Islamic world is confirmed by the economic model of the forecast of Islamic banking assets when it is influenced by digital technology factors. This model also proves the development of dualistic companies combining FinTech and Islamic finance, as well as the rapid development of the Islamic FinTech Ecosystem. 


\section{ACKNOWLEDGEMENTS}

The work is performed according to the Russian Government Program of Competitive Growth of Kazan Federal University.

\section{REFERENCES}

Bloomberg, J. (2019). What is digitization? Retrieved from https://www. digital-adoption-hub.com/digitization-vs-digitalization-vs-digital-adoptionconfused-dont-be/

Bulatova, E., Zakhmatovm, D., Aliakberova, L.Z., \& Koczar, J. (2016). Key developments and trends in project finance market. Academy of Strategic Management fournal, 15, 185-190. Retrieved from https://www.questia.com/ library/journal/1P3-4207753101/key-developments-and-trends-in-projectfinance-market

Demyanova, E. A. (2017). Development of companies in modern conditions of introduction of financial technologies. Property relations in the Russian Federation, 7(190), 104-113.

Firmansyah, E. A., \& Anwar, M. (2019). Islamic financial technology (FINTECH): its challenges and prospect. In Achieving and Sustaining SDGs 2018 Conference: Harnessing the Power of Frontier Technology to Achieve the Sustainable Development Goals (ASSDG 2018). Atlantis Press.

Islami Bank Bangladesh Limited. (n.d.). Islamic Banking: Some Conceptual Issues. Retrieved from https://www.islamibankbd.com/abtIBBL/cis_islamic_ banking_some_conceptual_issues.php

Islamic Fintech Report. (2018). Current Landscape \& Path Forward. Dubai Islamic economy development center, Dinar Standard.

Jamaldeen, F. (n.d.). What Is Islamic Finance? Retrieved from https://www. dummies.com/personal-finance/islamic-finance/what-is-islamic-finance/ 
Li, J., Merenda, M., \& Venkatachan, A. R. (2009). Business Process Digitalization and New Product Development: An Empirical Study of Small and Medium-Sized Enterprises. International Fournal of E-Business Research, 5(1), 49-64. doi: https://doi.org/10.4018/jebr.2009010103

Lim, S. (2019). Islamic Banking. Retrieved from https://www.investopedia. com/terms/i/islamicbanking.asp

Mastoor, S. A. (2014). Islamic banking system in Afghanistan. In Proceedings of the Proceedings of the 10th International Academic Conference, Vienna, Fun 2014, pages 439-488. Retrieved from https://econpapers.repec.org/paper/ sekiacpro/0200302.htm

Patrutiu-Baltes, L. (2016). The Impact of Digitalization on Business Communication. SEA - Practical Application of Science, IV(2(11)), 319-325. Retrieved from http://seaopenresearch.eu/Journals/articles/SPAS_11_21. pdf

Pollari, I., \& Ruddenklau, A. (2018). The Pulse of Fintech 2018. Biannual global analysis of investment in fintech. Retrieved from https://assets.kpmg/content/ $\mathrm{dam} / \mathrm{kpmg} / \mathrm{xx} / \mathrm{pdf} / 2019 / 02 /$ the-pulse-of-fintech-2018.pdf

S\&P Dow Jones Indices. (n.d.). Dow Fones Islamic Market. Retrieved from https://us.spindices.com/index-family/shariah/dow-jones-islamic-market

World Data Atlas. (n.d.). Retrieved from https://knoema.ru/atlas 
Edición Especial Special Issue Octubre 2019 DOI: https://doi.org/10.17993/3ctic.2019.83-2.258-273 


$$
\text { /19/ }
$$




\title{
INTERDISCIPLINARITY IN STUDYING MODERN RUSSIAN POETRY IN SCHOOL
}

\author{
Alina R. Gaynutdinova \\ Kazan Federal University, Kazan, Russia \\ Alfiya F. Galimullina \\ Kazan Federal University, Kazan, Russia \\ Artem E. Skvortsov \\ Kazan Federal University, Kazan, Russia \\ Sergey A. Zinin \\ Moscow Pedagogical State University, Moscow, Russia
}

E-mail: alfiya_gali1000@mail.ru

Recepción: 05/08/2019 Aceptación: 18/09/2019 Publicación: 23/10/2019

\section{Gitación sugerida:}

Gaynutdinova, A.R., Galimullina, A.F., Skvortsov, A.E. y Zinin, S.A. (2019). Interdisciplinarity in studying modern russian poetry in school. 3C TIC. Cuadernos de desarrollo aplicados a las TIC. Edición Especial, Octubre 2019, 274-285. doi: https://doi. org/10.17993/3ctic.2019.83-2.274-285

\section{Suggested citation:}

Gaynutdinova, A.R., Galimullina, A.F., Skvortsov, A.E. \& Zinin, S.A. (2019). Interdisciplinarity in studying modern russian poetry in school. 3C TIC. Cuadernos de desarrollo aplicados a las TIC. Special Issue, October 2019, 274-285. doi: https://doi. org/10.17993/3ctic.2019.83-2.274-285 


\section{ABSTRACT}

In the methodology of teaching literature and in school practice, traditionally much attention is paid to the problem of interdisciplinary connections, while the issues of intra-disciplinary interaction of literary material within the school course are not sufficiently developed by methodologists. The presence of this problem is felt especially acute in the study of literature in high school, when students " knowledge is generalized not only at the synchronic, but also diachronic levels. With consistent updating of various levels of artistic communication, the study of the historical and literary course acquires a broad dialogical focus, forming the skills of contextual examination of literary phenomena in students.

In this article, we will consider building intra-disciplinary relations in the lessons of studying modern Russian poetry at school. First, various artistic universals (archetypes, mythologems, topos, "eternal" motives) are actualized, which have important methodological significance and allow students to make broad historical and cultural generalizations at the lessons. Holistic comprehension of a work of art in the context of the historical and literary process is determined by the definition of various types of intertext artistic interactions (borrowings, imitations, parodies, reminiscences, citations) reflecting the principle of continuity of literary phenomena. At the same time, it is very important to identify historical and biographical ties, a creative dialogue between contemporary poets and poets of various eras. It can be mentoring, apprenticeship, co-authorship, rivalry, continuity, tradition actualization, "attraction - repulsion" type of relationships, influence, and others.

\section{KEYWORDS}

Methods of Teaching Literature, Intra-Disciplinary Relations, Innovative Methods of Teaching Literature, Modern Russian Poetry. 


\section{INTRODUCTION}

Intra-disciplinary relations links in literature lessons can be actualized primarily through students' perceptions of the successive connections of modern poetry with previous literature. The theoretical understanding of the issue of traditions in scientific literature is presented in various aspects: historical-philosophical, social-philosophical, cultural, axiological, historical-literary and methodological. Tradition is a multi-level category, requiring the study of artistic and aesthetic categories in their historical development, due, above all, to the specifics of the worldview of both the transmitting and the receiving parties.

The question of tradition is one of the urgent problems of modern cultural studies. In the works of foreign and Russian researchers: philosophers, ethnographers, cultural scientists, literary scholars and methodologists (K. Lévi-Strauss, V. Terner, S. S. Averintsev, E. A. Baller, Yu. B. Borev, A. S. Bushmin, A. Ya. Zis, O. A. Krivtsun, Yu. M. Lotman, A. F. Losev, E. Shatsky) the problems of the origin of tradition, its morphological structure and functional originality are considered (Lévi-Strauss, 2000; Shatsky, 1990).

The analysis of works devoted to the study of the problem of traditions allows us to identify the types of functioning of traditions. In the structural form, they can be represented as follows: background, quote, stylization, parody.

In this article, on the example of a lesson devoted to the actualization of intrasubject relations in the study of modern poetry, we turn to the lesson-analytical conversation in conjunction with the project's method, as well as the research students' activities. At the lesson, high school students develop skills of working with various information (reading and retelling of poetic text, complex, comparative and benchmarking analysis of works of art, working with literary-critical, cultural and historical sources, with scientific and popular literary texts, search skills and critical understanding of information taken from Internet sources). 
Consideration of modern Russian poetry in literature classes in high school in terms of the manifestation of traditions and innovation allows you to successfully prepare for the final exams. In preparation for thelesson "Traditions and Innovation in Modern Russian Poetry", the teacher invites students to independently choose one topic for independent research and development activities, the results of which will be presented in the lesson in the form of public defense of an individual or collective project (2-3 students in a group) accompanied with a multimedia presentation. Pupils are offered the following topics:

1. Are there copyrights of the traditional plot about the return of the prodigal son found in contemporary Russian poetry? What changes is undergoing this traditional plot scheme in specific works?

2. Continue the series of Russian poets with 2 - 3 names of modern poets who in their work presented the archetypical composition of the cosmos chaos: A. S. Pushkin, M. Yu. Lermontov, F. I. Tyutchev, A. A. Blok, S. A. Esenin, V. V. Mayakovsky.

3. Give 2 - 3 examples of poems from the works of modern Russian poets, which represent the image of the House, the hearth shelterin its archetypal sound.

5. Images of the moon and sun in the poetry of Russian classics and modern poets (M. V. Lomonosov, G. R. Derzhavin, A. S. Pushkin, M. Yu. Lermontov, F. I. Tyutchev, A. A. Fet, K. D. Balmont, A. A. Akhmatova, M. I. Tsvetaeva).

6. The theme of poetry and monument in Russian classical and modern poetry. Argue your answer with examples from $2-3$ works of art.

7. The game as an artistic device in classical and modern Russian poetry.

8. The role of parody in modern Russian poetry. 
This topic allows pupils to join the modern Russian poetry, to get acquainted with the life and work of modern poets of different directions (E. E Evtushenko, A. Voznesensky, B. Akhmadullina, J. Moritz, I. Lisnyanskaya, I. Mashinskaya, O. Chukhontsev, M. Amelin, A. Kouchner, E. Rein, I. Brodsky, S. Gandlevsky, etc.).

\section{METHODOLOGY}

The study of philosophical, cultural and literary works, revealing the scientific content of the terms "literary tradition", "continuity", "literary interrelations", "intertext" and others, allowed us to determine the theoretical content of the methodical system of forming ideas about literary traditions among senior pupils of secondary schools and gymnasiums.

The problem of interdisciplinary interrelations of the school literature course is thoroughly developed in the works of well-known scientists and methodologists S. A. Leonov, V. G. Marantzman, I. A. Podrugina, E. S. Rogover, V. F. Chertova, R. F. Mukhametshina, A. F. Galimullina, as well as in the publications of contemporary researchers: R. R. Zamaletdinova, G. A. Golikova, A. H. Vafina, various forms of lessons and methods for identifying intra-disciplinary relations are presented in the works of the Russian classics Literature teaching methods: G. I. Belenky, T. G. Brazhe, O. Yu. Bogdanova, V. A. Domansky (Podrugina, 2000; Zamaletdinov et al., 2016).

Zinin (2004) in the monograph "Intra-disciplinary connections in the study of the school's historical and literary course" offers a theoretically sound and proven in the practice of introducing the school curriculum for literature and textbooks the original system of using intra-disciplinary connections, both "horizontal" and "vertical » in high school, as well as identifying their role in shaping of the senior pupils reading culture. In our study, we rely on the methodology proposed by S. A. Zinin. 
In the publications of A. S. Afanasyev, T. N. Breeva, V. N. Krylova, N. G. Makhinina, N. G. Komar, the experience of studying modern Russian literature is presented in the context of successive links with the preceding Russian literature, as well as in the context of main trends of the global literary process (Afanasev et al., 2017; Afanasev \& Breeva, 2016; Krylov, 2017; Makhinina et al., 2017; Galitsky, 2016; Korsunsky, 1985).

All the mentioned studies became the methodological basis for our research and allowed us to develop a generalizing lesson using innovative technologies. The basis of the study were historical-genetic, historical-functional, comparative and typological approaches to the examination of modern Russian poetry, to reveal traditions, successive links with previous literature and innovation.

\section{RESULTS AND DISCUSSION}

This form of the lesson requires each pupil to thoroughly prepare independently after school hours. Pupils independently choose a topic for the project, select a material, conduct a comparative and comprehensive analysis of the works of modern Russian poets of choice, prepare a multimedia presentation at the final stage of the project, and during the lesson they defend their research work accompanied by a multimedia presentation. The project can be executed both individually and as a group of $3-4$ pupils.

Let's stop on some fragments of this lesson in more detail. Exploring the traditional for world, including Russian poetry, the theme of poetry and a monument in Russian classical and modern poetry, pupils choose creativity of poets who most clearly reflected this topic in their creativity. Pupils independently formulate this theme as "The theme of the poet and poetry in Russian literature" or "The theme of the immortality of poetry in Russian literature." Anticipating performances with projects, the teacher offers to think about what is a monument; what can be a monument to the poet, can the works of the poet become a monument to him? 
Pupils respond that the monument is a sculptural structure in memory of an outstanding writer, commander, statesman. The monuments are named to Peter I, M. V. Lomonosov, N. V. Gogol, G. Tukai, M. Jalil, P. I. Tchaikovsky. The pupils note that the best monument to the poet, writer, artist, musician is his own outstanding works, which are interesting for subsequent generations with their aesthetic value, humanistic aspiration, originality of thought and feeling, and harmonious sound. Poetry of M.V. Lomonosov, G.R. Derzhavin, A. S. Pushkin, M. Yu. Lermontov, F. I. Tyutchev survived their time. Next, pupils defend their project dedicated to this topic. They carry out a comparative analysis of the ode of Horace "To Melpomene", of its first translation into Russian by M. V. Lomonosov "My works defined the badge of immortality of mine ...", the original poems of G. R. Derzhavin "Monument", A. S. Pushkin "It's not a manmade monument that I've created for myself", "Monuments" by V. Bryusov and I. Brodsky and other modern poets who wrote various variations on the theme of a poetic monument. Pupils conclude that every poet, keeping the form of the original source, contributes to the development of this topic.

The special interest of pupils is attracted by the themes: "Game as an artistic technique in classical and modern Russian poetry" and "The Role of Parody in Modern Russian Poetry", which is closely related to the literature of postmodernism. Working on this topic, students turn to the creative works of I. Brodsky, T. Kibirov, S. Gandlevsky, O. Chukhontsev, D. Samoilov, Y. Levitansky, I. Irtenyev, Tsvetkov, A. Kushner, etc. During the lesson, students come to the well-founded conclusion that the game of the so-called "archaists" is an artistic device, among the "innovators" as the goal of poetry, and among the "centrists" as an expression of world perception.

\section{SUMMARY}

During reflection, students note that reading modern Russian poetry revealed a variety of authors' creativity, gave rise to a desire to learn more about their life path, even to communicate with them (pupils have such an opportunity, because 
many poets run personal websites and are very active on social networks). The lesson devoted to contemporary Russian poetry in the context of traditions convinced pupils that literature is a living and actively developing phenomenon of the modern cultural life of Russia.

One of the most important tasks of education of the qualified reader at school is development at pupils of ability to deep comprehension of the literary work as the complete art phenomenon. In the artistic impression a large role belongs personally significant to the reader. As E. O. Galitsky notes: “... there is an integrating beginning of the development of a person's thinking, his spiritual practices is meaningful reading" (Galitsky, 2016, p.7). Consequently, if the personal meaning of works of art is consonant with the personal sense of the perceiver or acquires such a meaning, then certain personal attitudes are developed, which are then realized out of art, in ordinary life situations. Then the thoughts and feelings of the writer are perceived by readers as their personal, innermost thoughts and feelings.

\section{CONCLUSIONS}

The structure of reading abilities is well developed by modern psychology and literature teaching methods (Korsunsky, 1985). The components of this structure are: reader's susceptibility, observation, reader's emotions, feelings, reader's empathy (ability to empathize), thinking with verbal and artistic images; reader's imagination, verbal-shaped memory. The development of these abilities is promoted: reading orientation, reading attitudes, needs, reading motives, the ability to relate what is read to life experience (Korsunsky, 1985, p.4 - 38) Consequently, the study of literature should be creative work, intense, responsible and exciting. 
Identification of various types of dialogical relations within Russian poetry from the depth of centuries to the present day allows us to significantly enrich the lessons of literature, form communication, reading and research competences of students, which allows pupils to maintain a high cognitive interest in the mastering Russian literature as a subject.

\section{ACKNOWLEDGMENTS}

The work is performed according to the Russian Government Program of Competitive Growth of Kazan Federal University.

\section{REFERENCES}

Afanasev, A., \& Breeva, T. (2016). Gender picture of peace in Russian women rock-poetry (poetic novels "Sprinter" and "StaLker" by Diana Arbenina). Fournal of Language and Literature, 7(1), 159-162. Retrieved from http://dspace.kpfu.ru/xmlui/bitstream/handle/ net/145386/SGOPUS 20780303 -2016-7-1-SID84998631659-a1. pdf;jsessionid=DCEBA61528BA2A3467B89851CADB7EC6? sequence=- 1

Afanasev, A., Breeva, T., \& Domansky, J. (2017). Poetic system interaction by Yanka Dyagileva and Egor Letov. Astra Salvensis, 5(10), 367-374. Retrieved from http://dspace.kpfu.ru/xmlui/bitstream/handle/net/130601/ SCOPUS23934727-2017-5-10-SID85038888217-a1.pdf? sequence=-1

Ghertov, V. F. (2012). School study of Russian literary classics in comparative historical coverage / V.F. Chertov. Study of Russian literary classics at school: yesterday, today, tomorrow: XIX Golubkovsky readings: digest of articles. MSPU, 5 - 11 .

Galitsky, E. O. (2016). Reading With Passion: Life-Creative Workshops. Bibliomir.

Korsunsky, E. A. (1985). Development of Literary Abilities of Pupils. Prosveshenie. 
Krylov, V. I. (2017). Ideas about national identity in russian literary review, historical and literary discourses of the 19th-early 20th century. $C B U$ international conference proceedings 2017: Innovations in Science and Education, 5, 680685. doi: https://doi.org/10.12955/cbup.v5.1007

Lévi-Strauss, G. (2000). The Mythologiques (vol.1, 2, 3, 4).

Shchepacheva, I., Komar, N., Makhinina, N., Sidorova, M., \& Berdnikova, O. (2017). Contemporary Christian Tale for Children: Questions of Poetics and Problems. Fournal of History Culture and Art Research, 6(4), 647-654. doi: http://dx.doi.org/10.7596/taksad.v6i4.1158

Podrugina, I. A. (2000). Typology of School Analysis of Epic Works in High School. Latmes.

Shatsky, E. (1990). Utopia and Tradition: Translation from Polish. Progress.

Zamaletdinov, R. R., Vafina, A. H., Mukhametshina, R. F., \& Golikova, G. A. (2016). The "New" Strategy in Teaching Literature in a Multiethnic Environment (as Exemplified by the Republic of Tatarstan). International Fournal of Environmental and Science Education, 11(6), 1237-1246. Retrieved from https://files.eric.ed.gov/fulltext/EJ1114295.pdf 
Edición Especial Special Issue Octubre 2019 DOI: https://doi.org/10.17993/3ctic.2019.83-2.274-285 


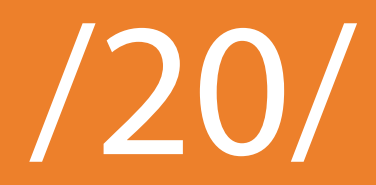




\section{FOREIGN EXPERIENCE IN THE INDIVIDUALS TAX CONTROL}

S.V. Salmina

Kazan Federal University, Institute of Management, Economics and Finance, Kazan, Russia

\section{A.M. Tufetulov}

Kazan Federal University, Institute of Management, Economics and Finance,

Kazan, Russia

V.I. Nasyrova

Kazan Federal University, Institute of Management, Economics and Finance,

Kazan, Russia

A.R. Khafizova

Kazan Federal University, Institute of Management, Economics and Finance,

Kazan, Russia

E-mail:svetasv21@yandex.ru

Recepción: 05/08/2019 Aceptación: 18/09/2019 Publicación: 23/10/2019

\section{Gitación sugerida:}

Salmina, S.V., Tufetulov, A.M., Nasyrova, V.I. y Khafizova, A.R. (2019). Foreign experience in the individuals tax control. 3C TIC. Cuadernos de desarrollo aplicados a las TIC. Edición Especial, Octubre 2019, 286-299. doi: https://doi.org/10.17993/3ctic.2019.83-2.286-299

Suggested citation:

Salmina, S.V., Tufetulov, A.M., Nasyrova, V.I. \& Khafizova, A.R. (2019). Foreign experience in the individuals tax control. 3C TIC. Cuadernos de desarrollo aplicados a las TIC. Special Issue, October 2019, 286-299. doi: https://doi.org/10.17993/3ctic.2019.83-2.286-299 


\section{ABSTRACT}

The exercise of control over the collection of taxes is one of the key links ensuring the replenishment of the treasury of the budget of any state. Therefore, a huge role is played by the tax authorities of the country. It is thanks to them that reliable and timely collection of taxes is carried out, the functions assigned to the tax system are implemented. Tax control is aimed at all subjects of the economy: both legal entities and individuals. Tax control is carried out in order to identify tax offenses, as well as ensuring the inevitability of bringing to justice for tax offenses. In order to implement these goals within the framework of tax control, it is necessary to ensure that checks are made for the correctness of the calculation and payment of taxes, the prevention of tax violations and the provision of compensation for damage caused to the state as a result of non-fulfillment by taxpayers of their duties. In this study, the authors consider the comparative characteristics of the tax systems of foreign countries and the Russian Federation. The analysis of the performance of on-site tax audits of individuals for 2014-2018 has been carried out. The authors concluded that some foreign trends in tax control could be relevant in Russia. After all, the constant development of forms and methods, as well as the very basis of tax control - the tax base, allows us to constantly improve the entire tax system in Russia, increase tax revenues and reduce the taxpayers' debt.

\section{KEYWORDS}

Tax, Taxation, Individuals, Tax Control, Foreign Experience. 


\section{INTRODUCTION}

Tax control over individuals always needs constant improvement, increasing productivity, maintaining financial stability and keeping up with time. Due to the fact that taxes and fees are a significant source of the revenue part of the state budget, it is tax control that acts as a priority for tax authorities. Therefore, the introduction of international developments can meet these requirements and introduce innovations and peculiarities to the tax control authorities of the Russian Federation. Consider the tax control of several countries, such as Japan, Germany and the United States. The choice of compared countries is due, first of all, to the diversity of their location. In addition, the tax system of each country is distinguished not only by its uniqueness, but also by its efficiency.

\section{METHODOLOGY}

In conducting the study, the methods of comparison and generalization, methods of statistical analysis and methods of analogy for determining risks were used.

\section{RESULTS AND DISCUSSION}

Speaking of Japan, it should be said that this is one of the most highly developed countries in the world in the field of economics and technology. One of the features of the tax system of Japan is that in this country the highest proportion of income taxes is compared with developed countries (Mityurnikova \& Revyakina, 2013, p. 30). It is also worth noting that the most significant income to the state comes from the income tax on individuals and legal entities, which in total exceeds 56\% of all tax revenues. For individuals in Japan, there is a progressive income tax scale, the tax rates for personal income are in the range from $10 \%$ to $50 \%$.

A detailed comparison of the main characteristics of the tax system of Japan and Russia, as well as the administrative authorities of these countries, is reflected in Table 1. 
Table 1. Comparative characteristics of the tax systems of Russia and Japan.

\begin{tabular}{|c|c|c|}
\hline Indicators & Russia & Japan \\
\hline $\begin{array}{c}\text { Tax rate } \\
\text { Ratios of direct and } \\
\text { indirect taxes, } \%\end{array}$ & Three level system & Three level system \\
\hline $\begin{array}{c}\text { Personal income tax\% } \\
\text { The revenue part of the } \\
\text { country's budget, \% }\end{array}$ & $45 / 55$ & $60 / 40$ \\
\hline $\begin{array}{c}\text { Progressive taxation } \\
\text { Tax management }\end{array}$ & 90 tax / 10 non-tax & 10, 20,30,37 tax / 15 non-tax \\
\hline $\begin{array}{c}\text { The Central Authority of the } \\
\text { state tax system }\end{array}$ & The Federal Tax Service & $\begin{array}{c}\text { Central Office - National Tax } \\
\text { Administration }\end{array}$ \\
\hline
\end{tabular}

Source: (Yegorov, 2017, p. 62).

In addition to the similar characteristics of the tax systems of the compared countries, various should be noted. These include the discrepancy in the organization of tax control expressed in various forms of responsibility (Solovyova \& Shevchenko, 2013, p. 49). Thus, in Russia, responsibility for violation of legislation on taxes and fees by individuals is divided into tax, administrative and criminal, provided in accordance with the Tax Code, the Code on Administrative Offenses and the Criminal Code. Whereas in Japan there is only tax and criminal liability provided for by acts of criminal administrative legislation.

Comparing the elements of the implementation of tax control over individuals in Russia and Japan, we can conclude that the Japanese tax system is more centralized, the administration is more rigid and limited by law. However, this does not at all indicate that the Federal Tax Service of Russia is not regulated by the norms of the law. The Russian tax authorities are more able to rely on an individual approach to each taxpayer, and therefore a greater likelihood of effective action. A comparison of the tax control systems of Japan and Russia also suggests that the state system is based primarily on the mentality of the country.

If you compare the tax system of Russia and the United States of America, you can also find many similar and excellent features. An interesting fact in this case is that the degree of compliance with the law in the United States is one of the highest in the world, the population pays about $83 \%$ of all taxes voluntarily 
and in accordance with the relevant provisions of the law (Gerb, 2015, p. 103). This demonstrates the good quality of the system of informing taxpayers about tax legislation and, at the same time, about sanctions that may follow in case of illegal behavior. In addition, such an indicator of taxpayers may indicate the peculiarities of the mentality of the country. Based on this consideration of the features of control in the United States will be important for comparison and analysis. The main provisions and aspects of the tax system are reflected in Table 2 .

Table 2. Comparative characteristics of the tax systems of Russia and the United States.

\begin{tabular}{|c|c|c|}
\hline Indicators & Russia & USA \\
\hline Tax rate & Three level system & Three level system \\
\hline $\begin{array}{c}\text { Personal income tax } \% \\
\text { Progressive taxation }\end{array}$ & 13 & $0,10,15,25,28,33,35,39.6$ \\
\hline Tax management & - & Progressive system \\
\hline $\begin{array}{c}\text { The Central Authority of the } \\
\text { state tax system }\end{array}$ & The Federal Tax Service & The Internal Revenue Service \\
\hline
\end{tabular}

The Central Authority of the state tax system in the United States at the federal level is the Internal Revenue Service (SVD), which is controlled by the Ministry of Finance. At the state level, state tax services act as a similar body. In addition, at the federal level under the SVD, the General Directorate for Tax Investigations operates, dealing with tax investigations and carrying out operational-search measures against unfair taxpayers.

Comparing the activities of the tax authorities of the United States and Russia, one can notice the fact that in these countries the interaction with taxpayers is actively developing. Interestingly, in the States, such assistance includes counseling through call centers, direct contact, the use of booklets with instructions for filling out declarations. In addition, there is a helpline in the USA that any resident can call and express concerns, suspicions, or reliable evidence of tax legislation (Morozov, 2009, p. 69). This indicates a high level of interaction between 
taxpayers and tax authorities. Mutual assistance can be one of the key reasons why the level of voluntariness in paying taxes among US citizens far exceeds that in other countries.

The next country in question is Germany. Here, the tax control is entrusted to the tax police of the country "Steufa". The most significant type of income in Germany, as in many other countries, are taxes. In this regard, special attention is paid to tax control. Consider the main provisions on the administration of tax policy, as well as the features of taxation in Germany, as reflected in Table 3.

Table 3. Comparative characteristics of the tax systems of Russia and Germany.

\begin{tabular}{|c|c|c|}
\hline Indicators & Russia & Germany \\
\hline Tax rate & Three level system & Three level system \\
\hline $\begin{array}{c}\text { Personal income tax\% } \\
\text { Progressive taxation }\end{array}$ & 13 & $\begin{array}{c}0,14,42,45 \\
\text { Tax management }\end{array}$ \\
$\begin{array}{c}\text { The Central Authority of the } \\
\text { state tax system }\end{array}$ & Ministry of Finance & $\begin{array}{c}\text { German Federal Ministry of } \\
\text { Finance }\end{array}$ \\
\hline
\end{tabular}

In Germany, the level of tax collection reaches $90 \%$, and tax evasion is an extremely unusual phenomenon for the Germans. Perhaps this is due to heightened legal awareness of citizens, and possibly the fact that tax crimes are included in the list of those who are criminally prosecuted by the tax police. In addition, in Germany there is a detailed and detailed legislation in the field of tax control. This leads to a reduction in misunderstanding, and accordingly, disputes between tax authorities and taxpayers. In addition to the above factors, it should be noted that it is an important fact that the banking system, the use of new technologies in tax services, the exchange of information between various services and government agencies - all this is at a sufficiently high and developed level.

Thus, comparing the tax control systems in Germany and Russia, it can be concluded that a number of features of the German system are repeated in the Russian one. In addition, they do not differ much from the characteristics 
considered as a result of the analysis of the previous three countries. Of course, in each country there are certain features that can be introduced into the tax control system of our country to further increase efficiency. However, one should consider the mentality of our country and the fact that not all the features can be taken from us. It is also worth noting that the tax control of most countries has similar features due to globalization and the emergence of new international projects, according to which member states should have a similar system of taxation and control. Therefore, the foreign experience of organizing tax control is relevant only in some specific areas of such control, and only considering the features of our own tax system.

Currently, foreign countries exercise tax control over individuals, combining three important aspects presented in Figure 1.

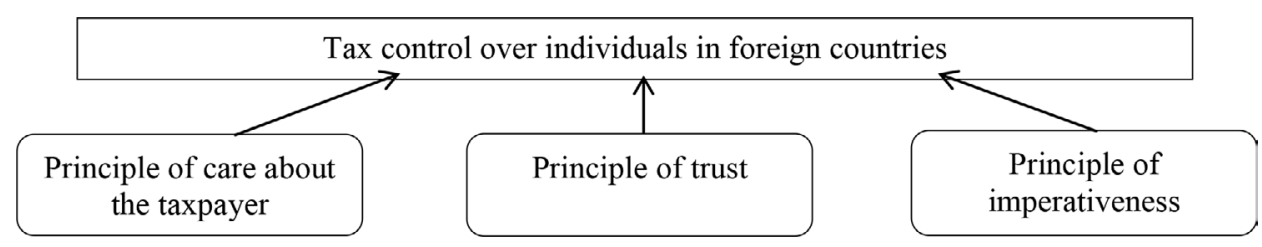

Figure 1. Principles on which tax control for individuals in foreign countries is based.

Thus, in many foreign countries with a stable tax system, since the end of the last century, tax authorities have been reformed. Many developed countries are modernizing their relations with taxpayers: in addition to the traditional "stick" (enforcing tax laws through various sanctions), the "carrot" has become widely used, that is, providing the taxpayer with the necessary services. As a service, tax advice, taxpayer training on how to prepare tax reports, the provision of other information and the provision of other assistance are offered. As the tax authorities of foreign countries implement the principle of caring for the taxpayer in the process of tax control over individuals, is presented in Table 4. 
Table 4. The implementation of the principle of care for the taxpayer in some foreign countries

\begin{tabular}{|c|c|c|}
\hline Characteristic & USA & Sweden \\
\hline $\begin{array}{c}\text { Assist taxpayers } \\
\text { in completing } \\
\text { declarations }\end{array}$ & $\begin{array}{l}\text { Each of the tax forms in the United } \\
\text { States contains detailed instructions } \\
\text { for filling it out. More than } 100 \\
\text { types of free brochures containing } \\
\text { information on various issues } \\
\text { related to tax declaration are issued } \\
\text { annually. One of these brochures } \\
\text { contains a complete catalog of free } \\
\text { services provided by tax authorities. } \\
\text { Instructions for completing } \\
\text { declarations can also be obtained } \\
\text { via an automated telephone system } \\
\text { or by calling a local telephone } \\
\text { number. In many libraries there are } \\
\text { videos with instructions for filling out } \\
\text { tax forms. }\end{array}$ & $\begin{array}{l}\text { Such a practice is widespread as } \\
\text { the independent preparation of tax } \\
\text { declarations for taxpayers, who then } \\
\text { receive this declaration through secure } \\
\text { channels of communication and can either } \\
\text { accept it or make their own changes and } \\
\text { additions. In the first case, it is enough for } \\
\text { them to confirm this declaration using an } \\
\text { electronic signature mechanism; in the } \\
\text { second case, they need to get in touch with } \\
\text { the tax service and provide the necessary } \\
\text { documentary evidence to substantiate the } \\
\text { proposed amendments and changes. }\end{array}$ \\
\hline
\end{tabular}

As can be seen from Table 4, foreign countries are currently building a system of such tax control, in which there is rationalization and simplification of tax procedures. And this is done both to simplify the work and optimize the working time of tax authorities, and to simplify and facilitate taxpayers. Therefore, a simplified approach to the collection and processing of tax reports is becoming more and more common in foreign countries. In this regard, in Sweden and Finland the tax authorities independently fill in declarations for individuals, and in the USA the tax authorities provide a wide range of tax services aimed at voluntary fulfillment of tax obligations. At the border of concern for the taxpayer and the imperativeness of tax control is the trust between taxpayers-individuals and tax authorities in foreign countries. This principle of trust is reflected in the existence of the institution of the fiscal rescript and the development of automated information systems of tax authorities, which is clearly reflected in Table 5.

Table 5. The implementation of the principle of trust in the implementation of tax control over individuals in foreign countries.

\section{Rescripcion Fiscal}

The taxpayer has the right to send a request about the legality of the proposed operation and to receive tax advice. The decision is mandatory for both the tax authorities and the taxpayer and is not subject to change.

USA The tax authority gives a written response to the taxpayer who made a preliminary request for the transaction, which he intends to conclude. 


\begin{tabular}{|c|c|}
\hline \multicolumn{2}{|r|}{ Rescripcion Fiscal } \\
\hline Sweden & $\begin{array}{c}\text { The tax law commission issues a preliminary opinion on the tax consequences } \\
\text { of a transaction. Preliminary detention is mandatory for tax authorities and is } \\
\text { applied provided that the taxpayer wishes this. }\end{array}$ \\
\hline Israel & $\begin{array}{l}\text { The taxpayer can ask for advice before the conclusion of the transaction, during } \\
\text { and after its completion, and the main condition is to file a request for a tax } \\
\text { decision before the deadline for the annual declaration. }\end{array}$ \\
\hline Germany & $\begin{array}{l}\text { The rescript procedure is limited to advising taxpayers on payroll tax, customs } \\
\text { duties, or assessing actual situations in connection with fiscal control. Published } \\
\text { positions expressed by the tax administration become mandatory for it, but do } \\
\text { not impose restrictions on the court. }\end{array}$ \\
\hline \multicolumn{2}{|r|}{ Automated information systems and technologies } \\
\hline USA & $\begin{array}{l}\text { To facilitate contact with taxpayers, a special computer program called Tele-File } \\
\text { has been introduced, which allows you to receive data from them by phone. } \\
\text { According to these data, within } 10 \text { minutes the program calculates the amount of } \\
\text { taxable income of a particular taxpayer and the amount of income tax due from } \\
\text { it. }\end{array}$ \\
\hline Australia & $\begin{array}{l}\text { All organizations of the country are registered through the website by electronic } \\
\text { contactless method within one day. Now the country is switching to the mode of } \\
\text { registering individual taxpayers online. }\end{array}$ \\
\hline
\end{tabular}

Source: (Elkina, 2014, p. 141).

Table 5 shows how a very interesting system of the institution of preliminary tax control and regulation is implemented in practice in some countries. Its meaning consists in the taxpayer agreeing with the tax authority the tax consequences of transactions before they are made. It is worth noting that, especially in Europe and the USA, the institute of preliminary tax regulation (it is also called the fiscal rescript) is a common form of tax control. The fiscal rescript is implemented in the course of signing tax agreements or receiving individual consultations (Solovyova \& Shevchenko, 2013, p. 66).

Speaking about the tax control system of individuals abroad, it is necessary to note the active use by the tax services of information technologies in interaction with taxpayers-individuals, which is also reflected in Tables 1, 2, 4 and which also builds on the principle of trust between the tax authority and the taxpayer. The overwhelming number of tax services in developed countries has specialized data processing centers (tax returns and tax payments). In data processing centers, the main work takes place with tax declarations of taxpayers-individuals at the primary tax control stage: when accepting declarations, processing them, comparing the information contained in them with other available data and directly transferring 
the results to the territorial tax authorities for subsequent control. Also, in many countries, certain services are provided by the tax authority for citizens to file tax returns electronically, pay taxes online and be able to track their tax obligations to the budget.

However, despite the growing tendency of trusting relationships with taxpayers and the development of a system of care for taxpayers, foreign tax authorities do not forget about the imperativeness of tax control.

\section{SUMMARY}

To begin, consider the activity on the performance of tax audits conducted in Russia, as disclosed in Table 4.

Table 4. The effectiveness of on-site tax audits in Russia.

\begin{tabular}{|c|c|c|c|c|c|}
\cline { 2 - 6 } & $\mathbf{0 1 . 0 1 . 2 0 1 5}$ & $\mathbf{0 1 . 0 1 . 2 0 1 6}$ & $\mathbf{0 1 . 0 1 . 2 0 1 7}$ & $\mathbf{0 1 . 0 1 . 2 0 1 8}$ & $\mathbf{0 1 . 0 1 . 2 0 1 9}$ \\
\hline $\begin{array}{c}\text { Total number of } \\
\text { on-site tax audits of } \\
\text { individuals }\end{array}$ & 6299 & 4470 & 3449 & 2600 & 1614 \\
\hline $\begin{array}{c}\text { Revealed violations } \\
\begin{array}{c}\text { The share of } \\
\text { inspections in which } \\
\text { violations were }\end{array}\end{array}$ & 6236 & 4399 & 3394 & 2441 & 1571 \\
\hline $\begin{array}{c}\text { revealed to the total } \\
\text { number }\end{array}$ & $98,99 \%$ & $98,41 \%$ & $98,41 \%$ & $93,88 \%$ & $97,34 \%$ \\
\hline
\end{tabular}

It is worth noting that the overall level of detection of offenses in Russia at the stage of on-site inspections is quite large. Comparing five reporting years, it can be concluded that the total number of inspections in Russia is decreasing. Thus, every year the implementation of the principles of tax law and the Concept of planning of field tax audits is demonstrated in the best way. Based on the fact that the number of checks is reduced, several conclusions can be drawn. This suggests that the election of taxpayers' subject to inspections is increasing. 
Secondly, a decrease in the quantitative composition also accompanies a positive qualitative change in the field checks. Reducing the range of attention of the tax authorities, the legislation places greater emphasis on the dangerous in terms of tax offenses of economic entities (Salmina et al., 2015).

At the same time, the effectiveness of tax audits is sometimes reduced or decreased. However, the range of values within which the value of the detected offenses differs is small: only $0.9 \%$. If we analyze the last reporting year, then in 2018 the total number of individuals on-site tax audits was 1614, of which 1571 violations were detected. The efficiency is $97.34 \%$, and this is a high percentage, given the heterogeneity of our regions and the different level of development of the economy and control authorities.

Thus, we can conclude that some foreign trends in tax control could be relevant in Russia. After all, the constant development of forms and methods, as well as the very basis of tax control - the tax base, allows us to constantly improve the entire tax system in Russia, increase tax revenues and reduce the taxpayers' debt (Balabanova Yuliya et al., 2018). Therefore, completing the consideration of the main directions for improving tax control in Russia, as a result of applying the experience of foreign countries, you can make the following suggestions:

a) Increasing attention to improving various methods of tax control, including its initial stage - tax accounting. Reforming can occur through the introduction of a single mandatory identification number for tax purposes, which makes it less dependent on government accounting authorities (Sabitova \& Khafizova, 2015; Artemenko et al., 2017).

b) Strengthening work on indirect methods of tax accounting. So, one of them may be control over the expenses of individuals, which will help to identify tax evasion.

c) Increasing the methods of working with taxpayers in order to increase the tax literacy of the population. The use of forms designed for different age groups and segments of the population. 
The work is performed according to the Russian Government Program of Competitive Growth of Kazan Federal University.

\section{REFERENCES}

Artemenko, D. A., Aguzarova, L. A., Aguzarova, F. S., \& Porollo, E. V. (2017). Causes of tax risks and ways to reduce them. European Research Studies Fournal, 20(3), 453-459. doi: https://www.researchgate.net/ publication/326734521_Causes_of_tax_risks_and_ways_to_reduce_them

Balabanova Yuliya, N., Nugaev Fatih, S., \& Khafizova Aigul, R. (2018). Perspectives of Tax Control Development for Individuals in Russia. Ad AltaJournal of Interdisciplinary Research, 8(1), 31-34.

Elkina, E. N. (2014). The history of tax audits. Agrarian Bulletin of the Urals, 6(124), 140-145.

Gerb, A. A. (2015). Features of the implementation of tax control in the United States. Scientific Almanac, 12-1(14), 103-105.

Mityurnikova, L. A., \& Revyakina, T. Yu. (2013). The tax system as the main regulator of the development of the tax potential of the state (Comparative analysis of the tax systems of Canada, Russia, Japan). Financial Analytics: Problems and Solutions, 5(143), 26-35.

Morozov, M. S. (2009). Foreign experience of increasing tax control. Bulletin of the Association of Universities of Tourism and Service, 2, 68-73.

Sabitova, N. M., \& Khafizova, A. R. (2015). Information technologies as a factor of evolution of tax administration. Mediterranean fournal of Social Sciences, 6(1), 169-173. doi: https://doi.org/10.5901/mjss.2015.v6n1s3p169 
Salmina, S. V., Khafizova, A. R., \& Salmin, I. V. (2015). Arrangement and performance of on-site tax auditing in the Russian federation. Mediterranean Fournal of Social SciencesVolume, 6(3), 732-735. doi: https://doi.org/10.5901/ mjss.2015.v6n3p732

Solovyova, N. E., \& Shevchenko, E. E. (2013). Comparative analysis of the tax administration system of Japan and Russia. Economy and Modern Management: Theory and Practice, 30, 42-49.

Yegorov, E. A. (2017). The direction of improving tax control in Russia with the experience of Japan. Energy of Science, 61-63. 


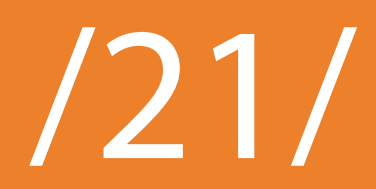




\section{RABOTNITSA AND BEZDEL'NITSA: RUSSIAN FEMININITIVES WITH SUFFIX -NITSA}

\section{Regina R. Guzaerova}

Kazan Federal University, Institute of Philology and Intercultural Communication E-mail: rguzaerova@gmail.com

\section{Drahomíra Sabolová}

Inštitút rusistiky, Filozofická fakulta Prešovskej Univerzity v Prešove

Vera A. Kosova

Kazan Federal University, Institute of Philology and Intercultural Communication

Recepción: 05/08/2019 Aceptación: 18/09/2019 Publicación: 23/10/2019

\section{Gitación sugerida:}

Guzaerova, R.R., Sabolová, D. y Kosova, V.A. (2019). Rabotnitsa and bezdel'nitsa: russian femininitives with suffix -nitsa. 3C TIC. Cuadernos de desarrollo aplicados a las TIC. Edición Especial, Octubre 2019, 300-315. doi: https://doi.org/10.17993/3ctic.2019.83-2.300-315

\section{Suggested citation:}

Guzaerova, R.R., Sabolová, D. \& Kosova, V.A. (2019). Rabotnitsa and bezdel'nitsa: russian femininitives with suffix -nitsa. 3C TIC. Cuadernos de desarrollo aplicados a las TIC. Special Issue, October 2019, 300-315. doi: https://doi.org/10.17993/3ctic.2019.83-2.300-315 


\section{ABSTRACT}

The article is concerned with the actual linguistic problem - the functioning of the designations of females with the suffix formant -ниц(a) / -nits(a) in modern Russian. The suffix -ниц(a) / -nits(a) is one of the most popular means of forming the derivational category of feminitivity, distinguished based on commonness of derivational meaning 'a female person belonging to the category of persons called a motivating noun'. The relevance of the study is determined by the increasing significance of female denominations as an object of linguistic research, as well as their activity in modern Russian media space. We understand media space as a global communication environment created by electronic means. The article has developed a classification of feminitives with the suffix -ниц(a) / -nits(a) based on the formal structure of a productive word. The language material for our study is 635 lexemes with the indicated suffix, selected from authoritative dictionaries of the modern Russian language, the National Corpora of the Russian language and the data from various Internet resources. The paper makes the conclusion about the stylistic universality of the female designations with the suffix -ниц(a) / -nits(a), that is, their ability to function in different styles of speech; lists social and linguistic factors under the influence of which the changes in this point of the derivational system occur.

\section{KEYWORDS}

Feminitivity, Word Formation, Feminitive, Gender, Neology, Derivation Category. 


\section{INTRODUCTION}

One of the most used means of the derivation category of feminitivity in the Russian language is the suffix formant -ниц(a) / -nits(a). This derivational type in terms of the category we are interested in - feminitivity - has a modification meaning 'a female belonging to the category of persons called a motivating noun'. The meaning of "a person based on gender" is distinguished following on from juxtaposition of the semes of "male" and "female" and correlates with the grammatical meaning of gender, with the exception of the group of personal generic nouns and masculine nouns with the lost seme "male", such as врач/ vrach (doctor) (Novikova, 2004; Igartua \& Santazilia, 2018). Such names usually designate a profession, a position, a specialty.

The category of personal nouns is traditionally one of the most significant objects of linguistic research, especially in relation to the gender (Safin et al., 2015; Bokale, 2010; Nikunlassi et al., 2011), including the derivational aspect (Makleeva et al., 2017; Makleeva et al., 2016; Neri \& Schuhmann, 2014), which determines the relevance of the present research.

Feminine personal nouns, as a rule, are formed from masculine nouns due to social factors and historical reasons. Until recently, the way to call women a separate word was the only possible way: жнец - жница / zhnets - zhnitsa (a reaper), ткач - ткаха / tkach -tkakha (a weaver), золотарь - золотарица/ zolotar' - zolotaritsa (a goldsmith), and in the 19th century a new tendency to generalize the names of persons in the form of a masculine gender did arise: поэт / poet, живописец/ zhivopisets (a poet, a painter). In the 20th century, this trend continued to develop rapidly, which led to a decrease, firstly, in the number of female derivatives being formed, and, secondly, in the frequency of using feminitives already existing in the language (feminine gender-specific profession title or other affiliation) (YankoTrinitskaya, 1966).

Derivative words with the female meaning have been studied well in diachronic and synchronous aspects: see the works by Novikova (2004), Zemskaya (2011), Berkutova (2017), Protchenko (1984), Yanko-Trinitskaya (1966); a description of 
the morphemic means of expressing the meaning of femininity is presented in Russian Grammar (Novikova, 2004; Zemskaya, 2011; Berkutova, 2017; Protchenko, 1984; Shvedova, 1980; Yanko-Trinitskaya, 1966).

The category of feminitivity is distinguished based on the generalized derivational meaning of 'female'. In terms of the semantics of the original word and the derivative, feminitivity is the derivational category of the modification type, since the main meaning of the producing word in the derivative is preserved, only the seme denoting female is added. The denominations of women form an independent derivation category according to the criterion formulated by R.S. Manucharyan: "In this language, one or another derivation category exists if the corresponding word-forming meaning is expressed by formal indicators, among which there is at least one that expresses - within the indicated framework - this meaning only (Manucharyan, 1981).

The derivational models of the category of word-formation of femininity are extremely diverse: Russian Grammar captures 10 basic modification types with a general meaning of femininity (Shvedova, 1980) among which there are those that express exclusively femininity.These include the models with suffixes of foreign origin -ш(a) / - $\boldsymbol{s h}(\boldsymbol{a})$ : авторша / avtorsha, архитекторша / arkhitektorsha, кассирша / kasirsha; -есс(а) / ess(a): стюардесса / styuardessa, пилотесса / pilotessa; -ис(a) / -is(a): актриса/ aktrisa, лектриса / lektrisa. The most popular of them is a derivational type with the suffix -ш(a)l $\boldsymbol{s} \boldsymbol{h}(\boldsymbol{a})$ which finds productivity mainly in colloquial speech: блогерша / blogersha, хакерша/ khakersha, менеджерша/ menedzhersha, байкерша / baikersha. The suffixes -к(a) / -k(a), -ин(я)/-ын(я) /in(ya), yn(ya), -иц(а) / its(a) derive the words to designate women (активистка / aktivistka, рабыня / rabynya, княгиня / knyaginya, мастерица / masteritsa, гостья / gost'ya) and female animals (голубка / golubka, гусыня / gusynya, волчица / volchitsa, летунья/letun'ya). The primordial Slavonic suffixes -ин(a) / -in(a) and -ниц(a) / -nits(a) express exclusively the meaning of feminitivity within the nominal category of persons (синьорина/ sin'yorina, учительница / uchitelnitsa). 
The object of our study is the feminitives with the suffix formant -ниц(a)/-nits(a) and their functioning in the modern Russian media space which is a special place for language implementation, generating new language forms. The influence of the communicative environment, namely the Internet, on constructing gender concepts in the language becomes an object of studying by linguists often (Miftakhova et al., 2018; Miftakhova et al., 2017; Bussmann \& Hellinger, 2001; Chelak, 2019; Bochina et al., 2015).

\section{METHODOLOGY}

The language material is represented by 635 lexemes with the suffix -ниц(a) I -nits(a) and has been selected by a continuous excerption from authoritative dictionaries of the modern Russian language (see Reverse Russian Dictionary, 1974; Kolesnikov, 2002; Yefremova, 2000). The analysis of the functioning of naming units denoting females in the language has been carried out based on material collected with the help of the NCRL (National Corpus of the Russian Language) (Russian National Corpus, 2019), media data and personal blogs on the Internet.

The research methods are based on: a) an integrated approach to the analysis of derived units; b) the analysis of the derivational structure and motivational relations; c) determining the specifics of functioning in speech.

\section{RESULTS AND DISCUSSION}

The suffix -ниц(a) / -nits(a) is one of the oldest means of expressing the derivation category of feminitivity in the history of the Russian language. Specialist in the field of historical word formation Azarkh (2007) writes: "The most productive model of correlation of naming units that designate persons on the basis of gender in the Old Russian period is the opposition of derivatives ending in -(bH) икъ and -(ьн)ица: ключьникъ / klyuchnik- ключьница / kluchnitsa". This type is 
common in many Slavonic languages: Ukrainian (монтажниця, сортувальниця, заступниця), Byelorussian (ўладальніца, вучаніца, чараўніца), Polish (robotnica, tanezcnica), etc.

In the Russian language the suffix -ниц(a)/-nits(a):

1) Is added to the masculine stems ending in the suffix-тель/tel' with the meaning 'a person classified according to an action being performed': воспитательница/ vospitatelnitsa (educatress), воительница / voitelnitsa (warrior), долгожительница / dolgozhitelnitsa (long-liver), писательница / pisatelnitsa (authoress), радиослушательница / radioslushatelnitsa (broadcast listener), свидетельница / svidetelnitsa (witness), учредительница / uchreditelnitsa (foundress), etc. (259 words - 41\%). According to the type of formal relations, the feminine word has a more compound form compared with the masculine noun (Zemskaya, 2011);

2) Correlates with the masculine naming units ending in -ник/ -nik. The meaning of the suffix is 'one who is associated with the activity, profession, implement or material of labor that is specified in the stem'. It concerns the derivatives such аs бортпроводница/ bortprovodnitsa (a stewardess), воспитанница / vospitannitsa (a pupil), десятиклассница / desyatiklassnitsa (a tenth grader), завистница / zavistnitsa (an envious lady), изменница/ izmennitsa (a traitor), помощница/ pomoshchnitsa (an assistant), художница / khudozhnitsa (an artist), etc. (376 words - 59\%). In this case, the feminine noun is the same in complexity with the masculine noun (Zemskaya, 2011).

Unlike other derivational types of the feminitivity category, for example, with the suffix $-\mathrm{\kappa}(\mathrm{a}) /-k(a)$, the suffix -ниц(a) /-nits(a) is associated exclusively with the above stems, which determines the lexical and semantic composition of this group of feminitives in which the job titles predominate. This allows the conclusion that the word-forming pattern with the suffix -ниц(a)/-nits(a) primarily is used in naming units related to human activity, professional one. 
According to the stylistic characteristics, 177 naming units of female ending in -ниц(a)/-its(a) (28\%) are marked as colloquial, 5 - as slang (0.8\%), 17 - as low colloquial $(2.8 \%)$, among which:

1) The feminitives are colloquial, and the masculine correlates are stylistically neutral (водитель / voditel' - водительница / voditelnitsa, заместитель / zamestitel' - заместительница / zamestitelnitsa, обозреватель / obozrebatel обозревательница / obozrevatelnitsa, охранник / okhrannik - охранница / okhrannitsa);

2) Both correlates are colloquial (изобразитель / izobretatel' изобразительница / izobretatelnitsa, напарник /naparnik - напарница / naparnitsa, обожатель / obozhatel'- обожательница / obozhatelnitsa).

33 feminitives with the suffix formant -ниц(a)/ -nits(a) are characterized in dictionaries as bookish, 10 - as official, 4 belong to high style, 2 - to church vocabulary (only 7.8\%), other lexemes belong to neutral style of speech (392 words $-62 \%$ ). One can argue that the suffixal pattern -ниц(a)-/ nitz(a) is the most universal means of expressing the meaning of feminitivity, and the derivatives with this formant are regarded by native speakers as stylistically neutral. The feminitives ending in -ниц(a) / - nits(a) are common in various functional styles of speech, from scientific communication (1) and journalism (2) to the language of fiction (3), and most often do not possess additional discursive marking:

(1) Известная исследовательница творчества Кракауэра Гертруда Кох обращает внимание в этой связи на один важный аспект: ««асса» больше не выражает ничьих частных интересов, она стала массой потребителей (Russian National Corpus, 2019);

(2) Сестра юного убийцы, 15 лет от роду, проходит по делу как свидетельница вместе с двумя остальными подростками, не принимавшими участия в жестокой расправе (Russian National Corpus, 2019); 
(3) И если позволяло время, монтажница звала её, она подсаживалась к монтажному столу (Russian National Corpus, 2019).

However, at the present time, feminitives remain outside the official business style of speech: the profession title учительница/ uchitelnitsa (teacher) is perhaps one of the most commonly used feminitives, however, the name of the AllRussian contest "У читель года" ("Teacher of the Year") and the honorary title “Заслуженный учитель России" ("Honored Teacher of Russia") exist only in masculine. The ability of the masculine form to call a person regardless of gender, and to unite men and women in the plural provides a similar opportunity to unify the naming units designating males and females in the official discourse. This is most consistently expressed in the language of jurisprudence where compliance with terminology requirements, in particular: unity, systematicity and impersonal character, implies the use of one common naming unit, for example, свидетель/ svidetel' (a witness), but not свидетельница/ svidetel'nitsa, that is often found in journalistic style and fiction.

At the present stage of the development of civilization, labor is the foundation of all human life. The level of engagement in labor activity in the largest sense of all adult members of society is higher than ever, which makes the profession one of the basic personal values. In the new conditions regulated by the economic laws of the market, the issue of professional identification and self-representation in the sociocultural and linguistic context is highly relevant. The use of feminitives and the formation of new ones according to the patterns existing in the language can be called one of the manifestations of linguistic reflection which is understood as the individual's ability to use the language consciously, to regulate speech and choose the appropriate communicative strategy (Troshina, 2010).

Thus, the use of existing female naming units with the suffix -ниц(а)/-nits(a) (начальница/nachalnitsa, правозащитница/pravozashchitnitsa, заместительница I zamestitelnitsa), the formation of new ones according to the same wordbuilding pattern (пользовательница/ polzovatelnitsa, анимешница/ animeshnitsa, землеустроительница/zemleustroitelnitsa) and the rethinking of feminitives in the 
language in a changing sociocultural context ( the word тысячница/ tysyachnitsa - earlier: "an advanced woman-worker, a collective farmer who performs with ten or more norms per working day" (Bochina et al., 2015); now it means: "a woman who has more than a thousand subscribers to her online blog") are aimed at solving several linguistic and communicative problems:

1) Language representation of women as qualified specialists and professionals whose importance can hardly be overestimated because of the importance of the profession in modern society;

2) Compliance with the grammar norm in the agreement of personal feminine nouns with the past tense of the verb in the form of feminine. It permits one to avoid the constructions like исследователь рассказала..., учитель получила... which, despite their common usage, still belong to the style of everyday conversation;

3) An indication of the gender via a female suffix as a part of the language game. For example, in the profile of a personal page on the Instagram social platform, the following form was used: красивая девочка электромонтажница/ krasivaya devochka elektromontazhnitsa (a beautiful electrician girl) (Instagram, 2019).

The suffixal type -ниц(a)/ -nits(a) belongs to the unstable part of the wordformation system of the Russian language where dynamic shifts occur under the influence of various, sometimes conflicting social and linguistic factors: seeking for the uniformity of naming people by profession, the language habit of combining lexical grammatical gender, the need to indicate the gender of a person in certain speech situations, the variety of word-forming patterns of the category of feminitivity and the unsystematic nature of their use in the field of non-usual vocabulary. 


\section{SUMMARY}

The derivation category of feminitivity is characterized by a variety of derivational models. The suffixal type in -ниц(a) / -nits (a) is one of the most highly productive in the category of feminitivity, which is proved by the analysis of 635 lexemes with this suffix that function in modern Russian. The prevailing part of the presented naming units has the semantics of the producer of the action and name women by professional and social affiliation. The suffix -ниц(a)/-nits(a) has a limited compatibility and is added either to the masculine stems ending in -тель/-tel' or to the stems ending in -ник/-nik with the apocope of the latter.

The word-formation type with the suffiх-ниц(a) /-nits(a) predominantly functions in a neutral style of speech (62\% of lexemes), which indicates the stylistic universality of the naming units formed according to this word-building pattern.

\section{CONCLUSIONS}

Thus, the word-formative pattern with the suffixal formant ниц(a) /-nits(a) is one of the most highly productive means of the word-formation category of femininity, which help designate female by professional, social and other belongings, mainly to the neutral layer of modern Russian vocabulary. A controversial nature of the use and formation of feminitives determines the prospect of further studies of word-formation processes taking place in modern Russian.

\section{ACKNOWLEDGMENTS}

The work is performed according to the Russian Government Program of Competitive Growth of Kazan Federal University. 


\section{REFERENCES}

Azarkh, Y. S. (2007). The Problem of the Connection of Word Formation and Morphogenesis in the History of the Russian Language (The Noun): Dissertation for Doctor of Philology. Moscow.

Berkutova, V. (2017). Feminine Gender-Specific Job Title in the Russian Language: Linguistic Aspect. St. Petersburg. Retrieved from https://www.psypart.com/ feminitivy-lingvisticheskii-aspect (Accessed February 05, 2019).

Bochina, T. G., Miftakhova, A. N., \& Malikov, A. Z. (2015). Internet as a resource of socio-linguistic researches. Social Sciences, 10(5), 626-632. doi: https://doi.org/10.3923/sscience.2015.626.632

Bokale, P. (2010). The formation of feminine nouns in Bulgarian. The results of a field investigation. Езиков свят-Orbis Linguarum, (2), 102-119. Retrieved from https:/ / www.ceeol.com/search/article-detail?id=242338

Bussmann, H., \& Hellinger, M. (2001). Doing gender in Russian. Gender across languages. An International Handbook. Dordrecht: Benjamins, 253-282.

Chelak, E. A. (2019). Feminine Gender-Specific Job Titles in the Discourse of Internet Communication. International Research fournal, 12(78) Part 2. - p. 197200. Retrieved from https://research-journal.org/languages/feminitivy-vdiskurse-internet-kommunikacii/ (Accessed May 06, 2019).

Igartua, I., \& Santazilia, E. (2018). How Animacy and Natural Gender Constrain Morphological Complexity: Evidence from Diachrony. Open Linguistics, 4(1), 438-452. doi: https://doi.org/10.1515/opli-2018-0022

Instagram. Retrieved from https://www.instagram.com/victoria_golubeva/ (Accessed May 26, 2019).

Kolesnikov, N. P. (2002). Explanatory Dictionary of the Designations of Women. Astrel. 
Makleeva, E. A., Zhike, Y., \& Kosova, V. A. (2017). Peculiarities of WordFormation of Derived Nouns with the Suffix-Yx-In Modern Russian Language. Ad Alta-fournal of Interdisciplinary Research, 7(2), 62-63.

Makleeva, E., Kosova, V., \& Miao, S. (2016). Jargon compressive nominations from the point of view of the Russian linguistic world-image. Fournal of Language and Literature, 7(1), 199-202. Retrieved from http://dspace.kpfu.ru/xmlui/bitstream/handle/ net/145395/SGOPUS20 780303-2016-7-1-SID 85002654045 -a 1. pdf;jsessionid $=424381$ A1476FA1AC3EB6015E1C3FA9B5? sequence $=-1$

Manucharyan, R. S. (1981). Word-Formation Meanings and Forms in Russian and Armenian: [Textbook for Philological Faculties].

Miftakhova A., N., Bochina T. G., \& Zhuravleva Yevgeniya, A. (2018). Gender interpretation of Russian lexeme БАБА/BАВA in Internet discourse. Herald NAMSCA, 3, 1118-1121.

Miftakhova, A. N., Bochina, T. G., \& Sergeeva, E. (2017). Gender Interpretation of Woman Lexeme in Internet Discourse. Fournal of Pharmacy Research, 11(11), 1336-1340. Retrieved from http://jprsolutions.info/files/ final-file-5alad0bd2da924.49943889.pdf

Neri, S., \& Schuhmann, R. (2014). Gender and word formation: The PIE gender system in cross-linguistic perspective. Kollektivum und Femininum: Flexion oder Wortbildung. Zum Andenken an Fohannes Schmidt, Leiden: Brill, 199-231.

Nikunlassi, A., Rissanen, M., Nevalainen, T., \& Saari, M. (eds). (2011). Gender in Grammar and Cognition. II: Manifestations of Gender. Trends in Linguistics. Studies and Monographs, 124, Berlin: Mouton de Gruyter, 771791. 
Novikova, M. R. (2004). The Features of Functioning of the Suffixes with the Meaning of Female in Slavonic Languages. Grammatical Categories and Units: Collection of Scientific Articles on the 75th Anniversary of A.B. Kopelovich. - Vladimir: VSPU, 224 p.

Protchenko, I. F. (1984). The Russian Language: The Problems of Learning and Development. Pedagogy, 222 p.

Reverse Russian Dictionary. (1974). About 125,000 Words. Soviet Encyclopedia, 944 p.

Russian National Gorpus. (2019). Retrieved from http://www.ruscorpora. ru/new/en/index.html (Accessed May 06, 2019)

Safin, I. K., Kolosova, E. I., \& Bychkova, T. A. (2015). Representation of gender concepts in the Russian and Polish languages. The Social Sciences (Pakistan), 10(5), 562-565. Retrieved from http://dspace.kpfu.ru/ xmlui/bitstream/handle/net/140029/SCOPUS18185800-2015-10-5SID84938696304-a1.pdf?sequence=-1

Shvedova, N. Y. (editor-in-chief) (1980). Russian Grammar. V. 1. Phonetics. Phonology. Stress. Intonation. Word Formation. Morphology. Nauka, 789 p.

Troshina, N. N. (2010). Language Culture and Language Reflection [Text]: An Analytical Review. Russian Academy of Sciences, Institute of Scientific Information for Social Sciences. Moscow: RAS ISISS.

Yanko-Trinitskaya, N. A. (1966). Designation of Females by Nouns of Female and Masculine Gende. Development of Word Formation of the Modern Russian Language. Nauka, 167-210.

Yefremova, T. F. (2000). The New Dictionary of the Russian Language. Explanation and Derivation: 136000 Entries. About 250,000 Semantic Units: [In 2 Volumes]. 
3C TIC. Cuadernos de desarrollo aplicados a las TIC. ISSN: 2254-6529

Zemskaya, E. A. (2011). Modern Russian. Word Formation: Textbook (3 $3^{\text {rd }}$ ed.), Extended. Flint: Nauka. 
Edición Especial Special Issue Octubre 2019 DOI: https://doi.org/10.17993/3ctic.2019.83-2.300-315 


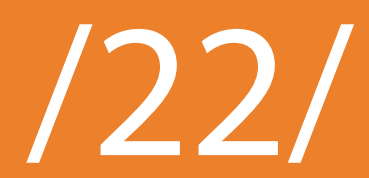




\section{MOVEMENT OF FINANCIAL RESOURCES IN AFFILIATED SMES}

Diana Shamilevna Usanova

Kazan Federal University, Institute of Management, Economics and Finance, Russia

Eugenia Urievna Strelnik

Kazan Federal University, Institute of Management, Economics and Finance, Russia

Elvira Ildarovna Khairullina

Kazan Federal University, Institute of Management, Economics and Finance, Russia

Elena Evgenievna Beloglazova

Kazan Federal University, Institute of Management, Economics and Finance, Russia

E-mail: diana-diana@rambler.ru

Recepción: 05/08/2019 Aceptación: 18/09/2019 Publicación: 23/10/2019

\section{Citación sugerida:}

Usanova, D.S., Strelnik, E.U., Khairullina, E.I. y Beloglazova, E.E. (2019). Movement of financial resourcesin affiliated SMES.3C TIC. Cuadernosdedesarrollo aplicados a las TIC. Edición Especial, Octubre 2019, 316-329. doi: https://doi.org/10.17993/3ctic.2019.83-2.316-329

\section{Suggested citation:}

Usanova, D.S., Strelnik, E.U., Khairullina, E.I. \& Beloglazova, E.E.(2019). Movement of financial resourcesin affiliatedSMES.3CTIC. Cuadernosdedesarrollo aplicados a las TIC. Special Issue, October 2019, 316-329. doi: https://doi.org/10.17993/3ctic.2019.83-2.316-329 


\section{ABSTRACT}

The object of the study is represented by non-public companies not listed on the Russian organized stock market, with related, subsidiary, affiliated companies. All companies are small and medium-sized enterprises. The subject of the study was cash flows of companies associated with the attraction, distribution and redistribution of financial resources within the affiliate structure. We observed 94 SMEs of the Republic of Tatarstan, forming 12 affiliated structures. In 92\% of affiliated structures, the interests of the owners of the parent companies or the interests of the owners of key companies were violated. The following results were obtained: we studied and described two main types of affiliated structures with violated interests of the owners; we highlighted the essential features of affiliated structures in which the interests of owners are violated; we described the basic scheme of movement of financial resources indicating a violation of the owners' interests; we proposed a method of justifying the price of providing financial resources for distribution within the affiliate structure.

\section{KEYWORDS}

Investor, Affiliates, Financial resources, Parent company, Tax effect, Cost of financial resources, Movement of financial resources, Cash flow. 


\section{INTRODUCTION}

The ability to generate and properly manage financial resources is an important feature of a successful company. This is especially true in the current conditions, when the unstable situation in the money and stock markets forces companies to look for alternative sources of financing. One of the options to optimize sources of financial resources is the creation of affiliated structures where it is possible to accumulate, distribute and redistribute both own and attracted financial resources. At the same time, it is important to lay the main criterion for the movement of financial resources, namely: financial resources should be distributed within the affiliated structure in the direction of their most efficient use, allowing to improve the welfare of the owners of the affiliated structure. In practice, this criterion is not always met, which leads to a decrease in the welfare of individual groups of owners in an affiliated structure, and therefore their interests are infringed.

In domestic legislation there is no unity in the definition of the terms "affiliated parties", "affiliated structure" (Civil Code of the Russian Federation, 1994; Federal Law on Joint-Stock Companies, 1995; Federal Law on Limited-Liabilities Companies, 1998; RSFSR Act on Competition and Limitation of Monopolistic Activity in Commodity Markets, 1991; Federal Law on the Protection of the Rights and Legal Interests of Investors on the Securities Market, 1999). For example, from a regulatory point of view, an affiliate structure can be understood as a group of legal entities that can influence the activities of legal entities engaged in entrepreneurial activity. The Civil Code interprets the term "affiliation" as "relatedness" (Civil Code of the Russian Federation, 1994).

In this matter, we will rely on the conceptual view set out in IAS 24 "Disclosure of information about related parties." Under the affiliated parties we will understand the company associated with the company that constitutes its financial statements (Young, 2000; Avdonina et al., 2016). This relationship may arise in the following situations: both companies are members of the same group of companies; one of the companies is associated with the other; companies conduct joint activities with each other, or with the same third party; one and the same individual has a 
significant impact on the activities of companies, etc. By an affiliated structure, we mean the aggregate of legal entities affiliated with each other (Ankudinov \& Lebedev, 2016; Akhmetov \& Rysaeva, 2015; Kirpikov \& Nugaev, 2016).

\section{METHODOLOGY}

The object of the study is represented by non-public companies not listed on the Russian organized stock market, with related, subsidiary, affiliated companies. All companies are small and medium-sized enterprises, in foreign practice the abbreviation SMEs is applied.

The subject of the study was cash flows of companies associated with the attraction, distribution and redistribution of financial resources within the affiliate structure (Kaspina et al., 2015; Shaykheeva, 2015; Fundamentals of Entrepreneurship: the study guide, 2017).

The study identifies similar signs, which make it possible to cast doubt on the expediency of attracting, distributing and redistributing financial resources within the affiliated structure. All the studied affiliated structures are characterized by the following main features, which are, in our opinion, essential in the matter of violation of the interests of investors (owners):

- The lack of public quotes for stock prices or public assessments of ownership shares in the company;

- The presence of two or more owners of the parent (key) company;

- The presence of at least five legal entities that are part of an affiliated structure.

To the selected features we should add quite often observed lack of competence of management in complex issues related to the peculiarities of the domestic financial legislation, as well as lack of knowledge of the modern financial fundamentals of business. 
In the course of the research, we identified and studied two main types of affiliated structures formed by non-public joint-stock companies and limited liability companies:

1) Affiliated structures consisting of a parent company, established, as a rule, in the form of a non-public joint-stock company, and a number of subsidiaries, established in the forms of limited liability companies;

2) Affiliated structures, consisting of several affiliated companies, created, as a rule, in the form of non-public joint-stock companies or limited liability companies with no pronounced parent company, however, consisting of one or several key companies. Key companies occupy a leading position in the affiliated structure, have the authority to make strategic and operational decisions that may affect the activities of the entire affiliate structure.

As a rule, the parent company in the form of a non-public joint-stock company, establishes a number of affiliated and subsidiary companies. One of the goals of creating, for example, subsidiaries can be vertical or horizontal integration, which will result in the achievement of additional synergistic advantages with a certain monetary value. Such integration is carried out in the interests of the owners only if the total market value of the company with its subsidiaries is higher than the value of the company without the establishment of subsidiaries. In the conditions of the modern Russian market, the justification for separating horizontally or vertically integrated subsidiaries, due solely to synergistic benefits, is questionable (Safiullin \& Gubaidullina, 2018; Gurianova et al., 2018).

Another goal of creating subsidiaries is to optimize the tax burden. In this case, it is possible to use transfer pricing, reorganize in order to obtain benefits for certain types of activities (for example, agriculture) or use other organizational and legal forms subject to preferential taxation; due to tax deductions (for VAT, export, etc.). The creation of such subsidiaries is carried out in the interests of the owners of the parent company if it can take advantage of the release of part of financial resources as a result of savings on tax payments. 
Creating subsidiaries, companies may pursue other goals. For example, optimization of the company's management system, political considerations, etc. However, if a joint-stock company grows within one region, city, district, when it is difficult to realize any other benefits besides synergistic and tax advantages, it is reasonable for owners to demand from management a justification of the reasons to create the new subsidiaries. The creation of new subsidiaries within an affiliated group may lead to a decrease in transparency within the group, and, consequently, the inability to assess the performance of managers. Creating new subsidiaries can occur at the request of individual owners, then, one of the consequences may be infringement of the interests of other owners included in the affiliated structure.

\section{RESULTS AND DISCUSSION}

Simplified, the flow of financial resources in an affiliated structure with the participation of the parent company is shown in Figure 1.

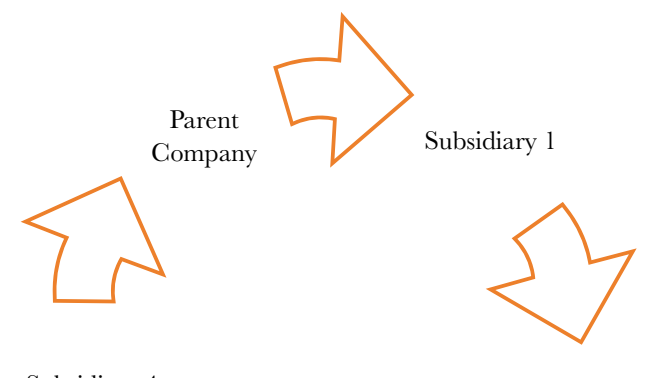

Subsidiary 4

Subsidiary 2

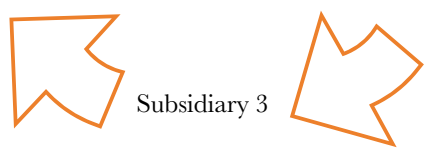

Figure 1. Movement of financial resources in an affiliate structure with the participation of the parent company.

In the variant presented in Figure 1, the interests of the owners of the parent company may be violated as follows: the parent company provides the subsidiary 1 with money in the form of a low interest (or interest-free) loan, and takes, in 
turn, money as an interest loan from the subsidiary 4. Redistribution of financial resources reduces the degree of informational transparency between subsidiaries. At the same time, in the corporate reporting of the parent company, the amounts issued are reflected in the composition of financial investments, and the funds received - in the form of paid long-term funding sources. If the parent company used its cash on its own, the corporate reporting amounts would be in the cash account, and there would be no increase in debt obligations. Table 1 presents the option when the parent company does not provide "non-market" lending to affiliated companies. To illustrate the example, assume that the company initially did not have paid sources of borrowed funds.

Table 1. Statement of financial position of the parent company without issuing funds to affiliated companies RuR.

\begin{tabular}{|c|c|c|c|}
\hline \multicolumn{1}{|c|}{ Assets } & \multicolumn{2}{|c|}{ Equity and liabilities } \\
\hline PPE & 500 & Ordinary shares, RuR 1 & 900 \\
\hline Inventories & 100 & & \\
\hline Cash & 400 & Trade payables & 100 \\
\hline Total & 1000 & Total & 1000 \\
\hline
\end{tabular}

Table 2 presents the option when the parent company sends its own funds to an affiliate company under "non-market" conditions and receives them back at "market prices". At the same time, suppose that in such a way 300 rubles are redistributed.

Table 2. The report on the financial position of the parent company after the redistribution of funds with the participation of affiliated companies RuR.

\begin{tabular}{|c|c|c|c|}
\hline \multicolumn{1}{|c|}{ Assets } & \multicolumn{2}{|c|}{ Equity and liabilities } \\
\hline PPE & 500 & Ordinary shares, RuR 1 & $\mathbf{9 0 0}$ \\
\hline Inventories & 100 & & 300 \\
\hline Financial investments & 300 & Long-term liabilities & 100 \\
\hline Cash & 400 & Trade payables & 1300 \\
\hline Total & 1300 & Total & 1300 \\
\hline
\end{tabular}


When the above-mentioned redistribution of the most liquid assets due to unreasonable market laws leads to a distortion of corporate reporting data, and, consequently, to incorrect analytical indicators, calculated on its basis, which, in turn, may affect the adoption of investment and credit solutions, both by the owners of the company and other stakeholders.

Affiliation of companies does not always mean the allocation of the parent company. Figure 2 presents one of the options for the movement of financial resources in affiliated structures without a pronounced parent company.

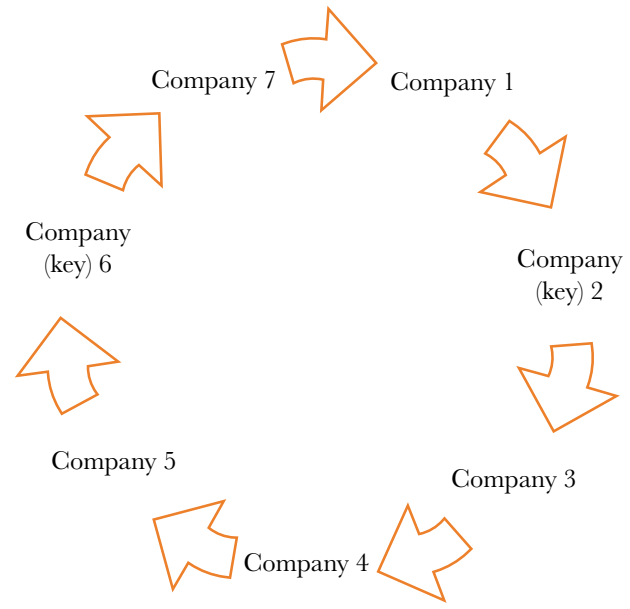

Figure 2. Movement of financial resources in an affiliate structure without a parent company.

In the course of the study, we concluded that in the variant presented in Figure 2 , the violation of the interests of the owners will occur in the same way as in the variant shown in Figure 1. Theoretically, the interests of the owners of any of the companies may suffer here, but in practice, as a rule, there is a violation of the interests of key companies' owners.

\section{SUMMARY}

It should be noted that in market conditions, the company's financial management is carried out in three main areas: management of investment projects (assets), management of sources of financing (liabilities) and management of dividend 
policy. Therefore, the distribution of financial resources within the affiliate structure in substantial amounts should contribute to the achievement of the company's long-term goals. Companies assume the implementation of certain investment projects and carry out a search corresponding to the cost and volume of financial resources. Investment projects should be economically viable, i.e. lead to an increase in the welfare of the company owners. In a market economy, the attraction of financial resources for the implementation of investment projects is fee-based. This means that each new ruble attracted will cost the company a few kopecks. If the parent (or key) company has a WAGC value of $18 \%$, then, by financing affiliated companies at an effective rate of less than 18\% per annum, it destroys its market value. An exception will be situations where the economic benefits from cooperation with an affiliated company, by monetary terms, will cover losses from the provision of financial resources at a "low" price.

In general, the minimum cost of financial resources for an affiliated company can be determined by the formula (1):

$$
\mathrm{CC}_{\min }=\mathrm{WACC}-\frac{\mathrm{NI}}{\mathrm{CE}_{\mathrm{af}}} \times 100 \%
$$

Where:

$\mathrm{CC}_{\text {min }}$ : the minimum cost of financial resources released to the affiliated company $(\%)$,

WACG: weighted average cost of capital of a company that disburses the financial resources to an affiliated company $(\%)$,

NI: is the company's annual net income from cooperation with an affiliated company $(\mathrm{RuR})$,

$\mathrm{CE}_{\mathrm{af}}:$ capital invested in an affiliated company - the total amount of financial resources provided to an affiliated company (RuR).

Providing the affiliate company with financial resources at the minimum price $\left(\mathrm{CG}_{\text {min }}\right)$, theoretically, will not entail a negative impact on the market value of the giver. 


\section{CONCLUSIONS}

During the study we observed 94 SMEs of the Republic of Tatarstan, forming 12 affiliated structures. In $92 \%$ of affiliated structures, the interests of the owners of the parent companies or the interests of the owners of key companies were violated. Consequently, the problem of protecting the interests of investors in affiliated SMEs is extremely acute today.

The need to protect the interests of investors in the movement of financial resources is primarily due to the low degree of transparency of information provided by a non-public SMEs to its owners regarding cash flows and their distribution and redistribution within an affiliated group of companies.

Thus, based on our study, the following results were obtained:

- We studied and described two main types of affiliated structures with the violated interests of the owners;

- We highlighted the essential features of affiliated structures in which the interests of owners are violated;

- We described the basic scheme of movement of financial resources indicating a violation of the interests of owners;

- We proposed a method of justifying the price of providing financial resources for distribution within the affiliate structure.

In our research, we were faced with the fact that none of the available databases contain information about affiliated structures in the planes we need, which significantly limited our research. Nevertheless, we obtained the results described in this article, which can be a subject for discussion, as well as a starting point for further research. 


\section{ACKNOWLEDGEMENTS}

The work is performed according to the Russian Government Program of Competitive Growth of Kazan Federal University.

\section{REFERENCES}

Akhmetov, R., \& Rysaeva, G. (2015). The problems of financial cycle modeling in the globalization of financial markets. Procedia Economics and Finance, 27, 522-528. doi: https://doi.org/10.1016/S2212-5671(15)01014-X

Ankudinov, A. B., \& Lebedev, O. V. (2016). Dividend payouts and company ownership structure amid the global financial crisis: evidence from Russia. Post-Communist Economies, 28(3), 384-404. doi: https://doi.org/10.1080/1463 1377.2016.1196882

Avdonina, S. G., Podgornaya, A. I., \& Grudina, S. I. (2016). The Role of the State in Intergation with the Participation of Subjects of Innovative Entrepreneurship (On The Example of the Russion Federation). 3rd International Multidisciplinary Scientific Conference on Social Sciences and Arts, SGEM. - Political Sciences, Lare, Finance, Economics and Tourism Conference Proceedings, IV, 841-847. doi: https://doi.org/10.5593/SGEMSOCIAL2016/B24/S07.110

Civil Code of the Russian Federation. (1994, 30 November). Part 1. \#51-FZ

Federal Law on Foint-Stock Companies. (1995, 26 December). \#208-FZ

Federal Law on Limited-Liabilities Companies. (1998, 8 February). \#14-FZ

Federal Law on the Protection of the Rights and Legal Interests of Investors on the Securities Market. (1999, 5 March). \#46-FZ

Kazan Federal University. (2017). Fundamentals of Entrepreneurship: the study guide. Kazan: Publishing house of Kazan Federal University. Retrieved from https://dspace.kpfu.ru/xmlui/bitstream/handle/net/117080/ Fundamentals_of_entrepreneurship___VERSTKA___01.11.2017. pdf ? sequence $=2 \&$ is Allowed $=y$ 
Gurianova, E. A., Gurianov, I. N., \& Mechtcheriakova, S. A. (2018). Influence of characteristics of the organizational structure of management on level and structure of transactional costs of firm. Fournal of Social Sciences Research, 4(5), 260-264. Retrieved from http://paper.researchbib.com/view/ paper/199834

Kaspina, R. G., Molotov, L. A., \& Kaspin, L. E. (2015). Cash flow forecasting as an element of integrated reporting: an empirical study. Asian social science, 11(11), 89-94. doi: http://dx.doi.org/10.5539/ass.v1 ln1 1p89

Kirpikov, A. N., \& Nugaev, F. S. (2016). Relevant approaches to performing analysis of financial results of organization's activity with application of factor models. International Business Management, 10(15), 2987-2991. Retrieved from https://www.medwelljournals.com/abstract/?doi=ibm.2016.2987.2991

RSFSR Act on Competition and Limitation of Monopolistic Activity in Commodity Markets. (1991, 22 March). \#948-I

Safiullin, A. R., \& Gubaidullina, A. I. (2018). Approach To Risk And Investment Attractiveness Estimation For Regional Economic Activity Of Russia. International Transaction Fournal of Engineering Management \& Applied Sciences \& Technologies, 9(5), 455-467. Retrieved from http://tuengr.com/ V09/455M.pdf

Shaykheeva, D. K. (2015). Analysis of SMEs in Medium-sized Cities' Influence Zone in Tatarstan. Procedia Economics and Finance, 24, 620-624. doi: https:// doi.org/10.1016/S2212-5671(15)00650-4

Young, S. D. (2000). EVA And Value-Based Management: A Practical Guide to Implementation. By S. David Young and Stephen F. O'Byrne, The McGrawHill Companies, Inc. 
Edición Especial Special Issue Octubre 2019 DOI: https://doi.org/10.17993/3ctic.2019.83-2.316-329 


$$
\text { /23/ }
$$




\section{TAX DEBT AND WAYS OF REDUCING IT}

M.E. Orlova

Kazan Federal University, Institute of Management, Economics and Finance,

Kazan, Russia

V.I. Nasyrova

Kazan Federal University, Institute of Management, Economics and Finance,

Kazan, Russia

S.V. Salmina

Kazan Federal University, Institute of Management, Economics and Finance,

Kazan, Russia

E-mail:ff104@mail.ru

Recepción: 05/08/2019 Aceptación: 20/09/2019 Publicación: 23/10/2019

\section{Gitación sugerida:}

Orlova, M.E., Nasyrova, V.I. y Salmina, S.V. (2019). Tax debt and ways of reducing it. 3C TIC. Cuadernos de desarrollo aplicados a las TIC. Edición Especial, Octubre 2019, 330-345. doi: https://doi.org/10.17993/3ctic.2019.83-2.330-345

Suggested citation:

Orlova, M.E., Nasyrova, V.I. \& Salmina, S.V. (2019). Tax debt and ways of reducing it. 3C TIC. Cuadernos de desarrollo aplicados a las TIC. Special Issue, October 2019, 330-345. doi: https://doi.org/10.17993/3ctic.2019.83-2.330-345 


\section{ABSTRACT}

The article discusses scientific and legal approaches to the classification of tax debt, analyzes the state of tax debt in Russia for the period from 2013 to 2018. The main causes of tax debt are the deterioration of the financial condition of an economic entity, an individual, as a result of the financial crisis in the country, or deliberate evasion of the payment of mandatory payments by the taxpayer himself. Among the factors affecting the increase in tax debt, should be highlighted, the use of such schemes to avoid tax debt as reorganization, liquidation, merger, merger, division, separation. In the context of various classification groups, proposes new classification groups of tax arrears, incl. to expand its analysis and administration. The article clarifies the concepts of tax debt, settled and unregulated tax debt for the purposes of tax administration and conducting analytical work. The directions for the development of tax debt tax administration are proposed. For tax administration purposes would be to use the tax debt classification by type of organizations-debtors, including by type of economic activity. This will improve the performance of the tax authorities to collect tax debts. It seems appropriate to develop a program of actions for administering different types of taxpayers and collecting tax arrears, and in the future, it is possible to prevent the occurrence of tax arrears.

\section{KEYWORDS}

Arrears, Tax debt, Bankruptcy, Unresolved debts, Tax audit, Tax control measures. 


\section{INTRODUCTION}

The tax code of the Russian Federation does not give a legal interpretation of the term "tax debt", but offers only the concept of arrears, as the amount of tax or fee not paid in the period established by the legislation on taxes and fees (Article 11 of the RF Tax Code), which entails the accrual of penalties. This affected the availability of a variety of interpretations of this category by scientists and practitioners. Tax debt is the most important subject of tax administration, since it is a significant destabilizing economic component that affects the formation of state financial resources. Tax debt is the most important subject of tax administration, since it is a significant destabilizing economic component that affects the formation of state financial resources.

\section{METHODOLOGY}

In conducting the study, the methods of comparison and generalization, methods of statistical analysis and methods of analogy for determining risks were used.

\section{RESULTS AND DISCUSSION}

To indicate unfulfilled obligations, "debt" is used in many ways. The Tax Code of the Russian Federation contains only a definition of arrears as the amount of tax or fee that was not paid within the time period established by the legislation on taxes and fees (Article 11 of the Tax Code of the Russian Federation). The term "debt" is used in the Tax Code of the Russian Federation both in respect of taxes and fees, and in respect of fines and penalties without any explanation.

In explanatory dictionaries Ozhegova (1986) and Ushakov (1935), in the Modern Economic Dictionary (Raizberg et al., 1999), debt is the sum of outstanding obligations to be repaid by a business entity within a certain period of time. It is worth noting that the concept of "debt" is used by the legislative authorities, the executive authorities, lawyers, economists, scientists and others. The concept of "tax debt" is presented in the works of many scientists (Picture 1). 
From the above definitions, the authors draw attention to the fact that the tax debt consists of unpaid taxes, fines and penalties. So, such authors as Aushev (2004), Bondar (2011) tax liabilities are unfulfilled tax liabilities, including fines and penalties. Isaev (2000), Lebedev (1998) Also, tax arrears include unpaid taxes and fees, fines and penalties that the tax authorities accrued. The most complete definition is given by Pronin (2016), which is clearly seen in Picture 1.

In our opinion, at present, tax arrears include unfulfilled obligations on taxes, fees, insurance premiums, penalties accrued on them and fines for violating the legislation on taxes and fees. We propose to consolidate the concept of "tax debt" in the Tax Code of the Russian Federation, which is understood as the aggregate of unfulfilled taxpayers, tax agents, payers of fees and insurance premiums in the period established by tax legislation for the payment of taxes, fees, insurance premiums, as well as accrued fees and penalties sanctions on them.

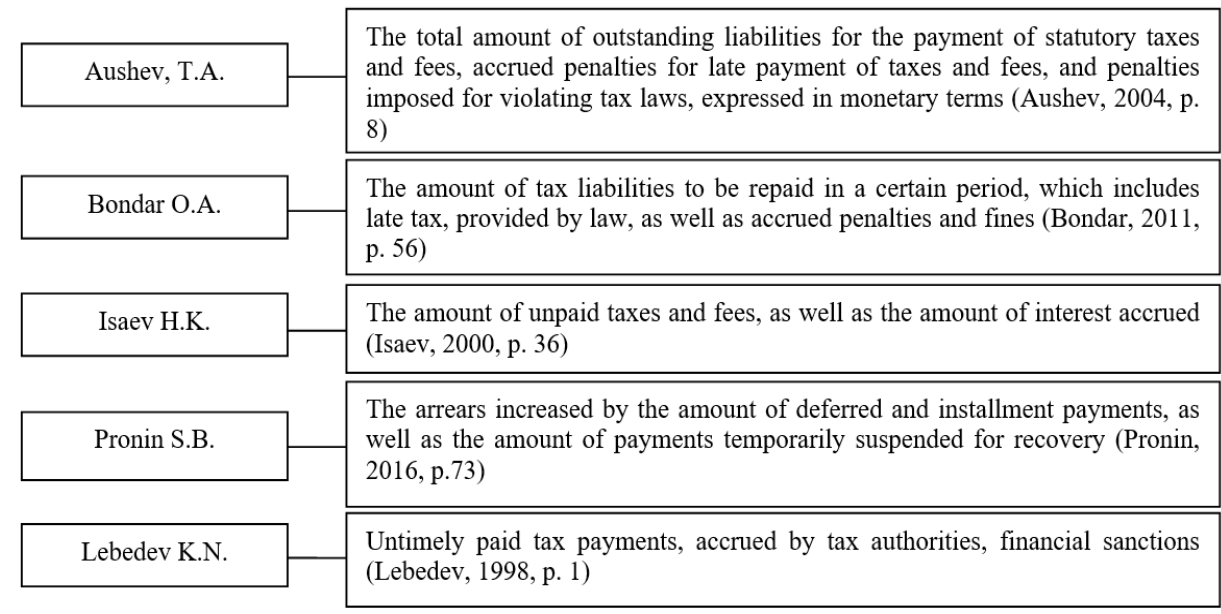

Picture 1. The definition of the concept of "tax debt" proposed by different authors.

Based on the norms of the Tax Code of the Russian Federation, we can identify two main groups of tax debts: current tax debts and tax debts identified in the framework of tax audits (Picture 2). 
In turn, within each group there are three types of tax arrears: arrears (current, arising from the results of tax declaration and accrued according to the calculations of the tax authority; arrears identified as a result of tax audits); arrears of interest accrued as a result of the current arrears; arrears of penalties for current arrears and the results of tax audits; tax arrears accrued as a result of tax audits; tax arrears due as a result of other tax control measures. It should be noted that the current and identified arrears in the process of tax audits have various financial implications. So if there is a current debt, the financial consequence is a penalty, or according to the interpretation of the Tax Code of the Russian Federation, the method of security for tax payment (Article 75 of the Tax Code). If there are arrears identified by the tax authorities based on the results of tax audits, in addition to the penalty, the tax consequence may be a financial consequence. This fact is part of the tax offense.

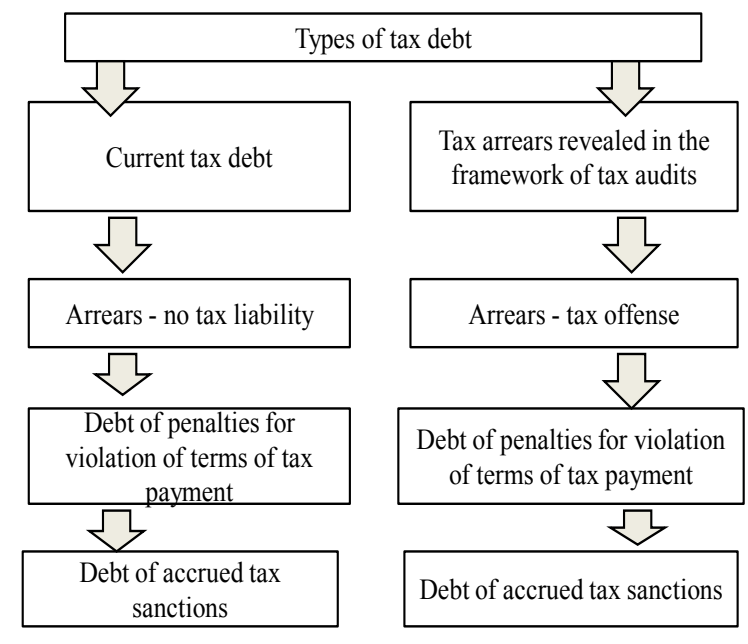

Picture 2. Types of tax debt (Official site of the Federal Tax Service of Russia).

Picture 3 shows the dynamics of tax debt in the context of arrears, penalties and tax sanctions. At the end of 2017, the arrears of interest were $22 \%$, and the tax sanctions $-2.6 \%$. There has been an increase in arrears and a reduction in tax arrears and penalties. 


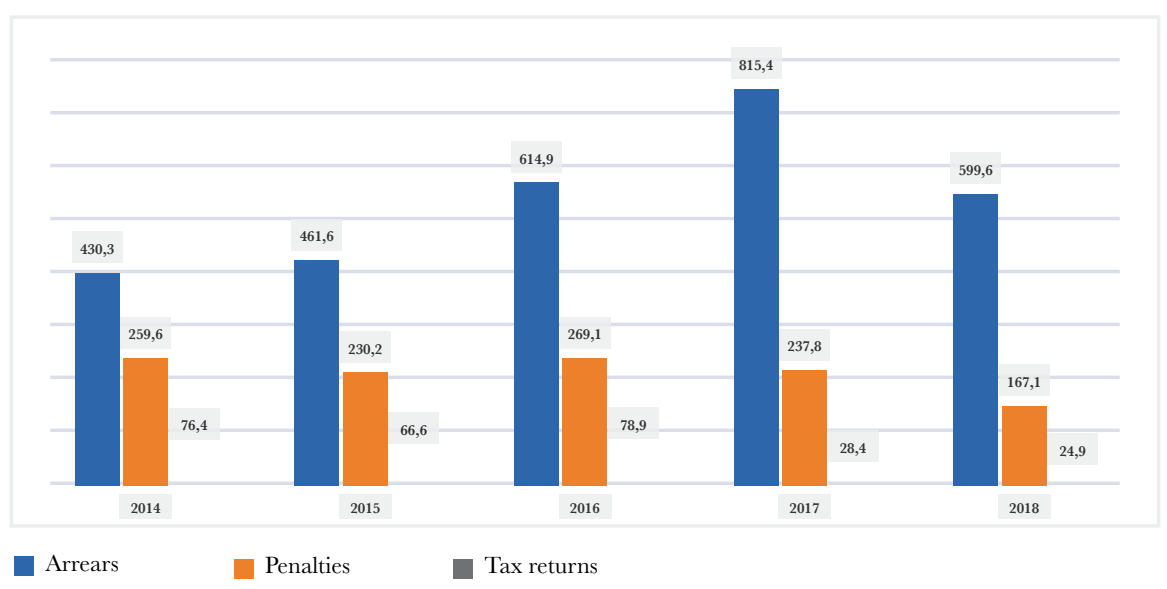

Compiled based on the statements of the Federal Tax Service of Russia (Official site of the Federal Tax Service of Russia).

Picture 3. Dynamics and composition of tax debt as of 01.01.2019.

The main causes of tax debt are the deterioration of the financial condition of an economic entity, an individual, as a result of the financial crisis in the country, or deliberate evasion of the payment of mandatory payments by the taxpayer himself. Among the factors affecting the increase in tax debt, should be highlighted, the use of such schemes to avoid tax debt as reorganization, liquidation, merger, merger, division, separation. A legal entity created by merging with another organization, or reorganized, will not pay anything to the budget, since it will subsequently be liquidated or there will be another way to get rid of it, for example, through another reorganization.

Another reason for the growth of tax debt is the imperfection of the institution of bankruptcy. Most of the enterprises and organizations undergoing bankruptcy proceedings have a significant tax payment debt. At the same time, the implementation of the norms of insolvency (bankruptcy) legislation is the last opportunity for the tax authorities to recover the arrears in payments to the budget and extra-budgetary funds. However, in practice, the bankruptcy process is the least effective measure to recover (repay) tax debt. 
Significant problems exist in the joint work of the tax authorities and the Federal Bailiff Service to execute decisions to collect tax arrears at the expense of the debtor's property, and more specifically, the inability to repay the debt at the expense of liquid assets during the implementation of the enforcement proceedings.

These tax debt problems are not new to tax administration, but effective methods to combat this problem are not enough for today. As practice shows, even if the tax authorities manage to bring the case to court and prove the fact of intentional liquidation, it is practically impossible to collect the debt from the debtor.

Tax debt should be considered as a total tax debt, which consists of settled debt and unresolved debt. Debt settlement includes deferrals and installment plans for the payment of tax payments by the decision of tax authorities, courts, as well as the suspension of penalties until a decision is made by an arbitration court. Unsettled debts include arrears, impossible to collect debts. Tax arrears, fees and insurance premiums affect the revenues of the consolidated budget of the Russian Federation and can lead to a significant reduction in budget expenditures on the most significant projects and programs.

The tax authorities in the framework of statistical reporting distinguish two main types of tax debt: unresolved and settled (see Picture 4).

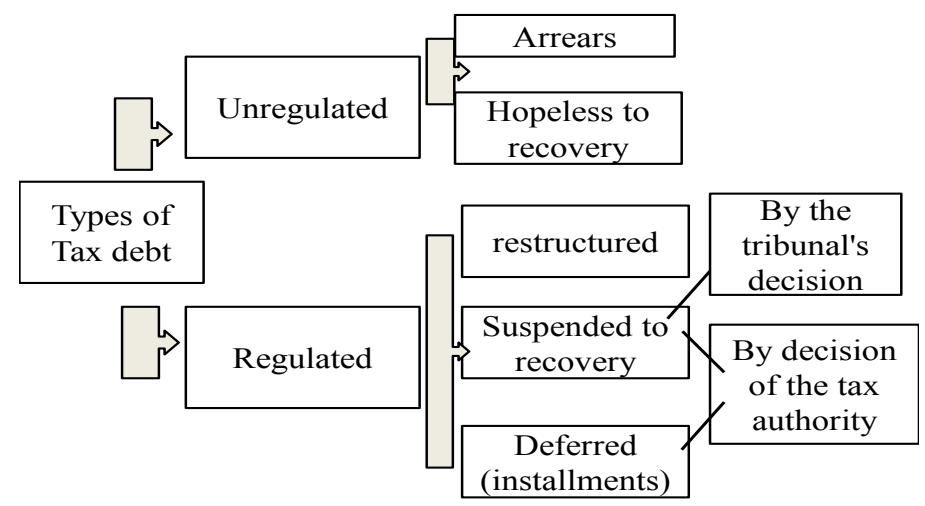

Picture 4. The treatment of types of tax arrears from the point of view of the Federal Tax Service. 
Unsettled debts include arrears and debts uncollectible. The arrears include the amounts of taxes that have not been paid within the prescribed period, in respect of which the terms of application of measures of collection and settlement are valid. The peculiarity of bad debts lies in the fact that they are not subject to collection, restructuring or rescheduling. Bad debts are not subject to regulation due to certain circumstances, such as the death of the taxpayer, the impossibility of establishing its actual location, registration of the taxpayer on forged documents, liquidation in bankruptcy, etc.

Regulated debt, as a rule, is a debt, according to which a certain decision is made on postponement of payments, in particular on restructuring, deferral, installments, investment tax credit, as well as payments suspended for collection in connection with the relevant decision of the tax authority or entered into force of a judicial act. The settlement of the settled debt is made by phased payment in accordance with the conditions and procedure approved by the Government of the Russian Federation, or by an agreement or decision. Figure 6 shows the dynamics of various types of debt according to the above classification criteria.

In Russia, the indicator is the ratio of the tax debt to the volume of taxes, fees, insurance contributions to the budget system of the Russian Federation. This indicator characterizes the efficiency of the tax authorities in the settlement of tax arrears. Picture 5 shows the dynamics of this indicator over 13 years. 


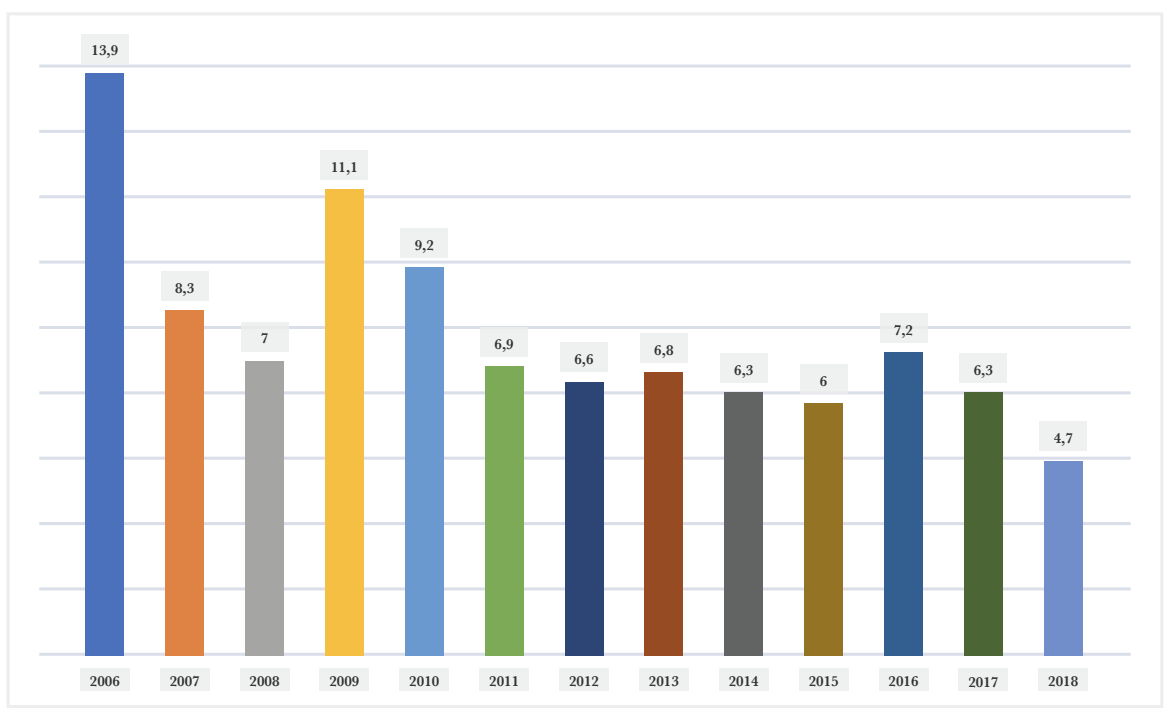

Picture 5. The ratio of the tax debt to the amount of taxes, fees, insurance premiums in the budget system of the Russian Federation, in \%.

In the Russian Federation, there is a tendency to a decrease in the ratio of the tax debt to the volume of taxes, fees, insurance contributions to the budget system of the Russian Federation. So, in 2018 compared with 2006, this ratio decreased by more than 2 times. Also in Figure 2 one can observe a noticeable increase in the ratio of debt to revenues in 2009 compared with 2008 by $2.1 \%$, and in 2016 compared with 2015 by $1.2 \%$. These phenomena are associated with global financial crises. However, it should be noted that the decrease in this indicator in subsequent years is due to a significant increase in taxes, fees, insurance contributions to the budget system of the Russian Federation. Therefore, further development of measures to reduce tax arrears is necessary.

It should be noted that in Russia as a whole, the tax debt of both individuals and legal entities increases annually, although as of January 1, 2018 compared with January 1, 2017, this indicator for legal entities decreased by $1.87 \%$ (Picture 6). 


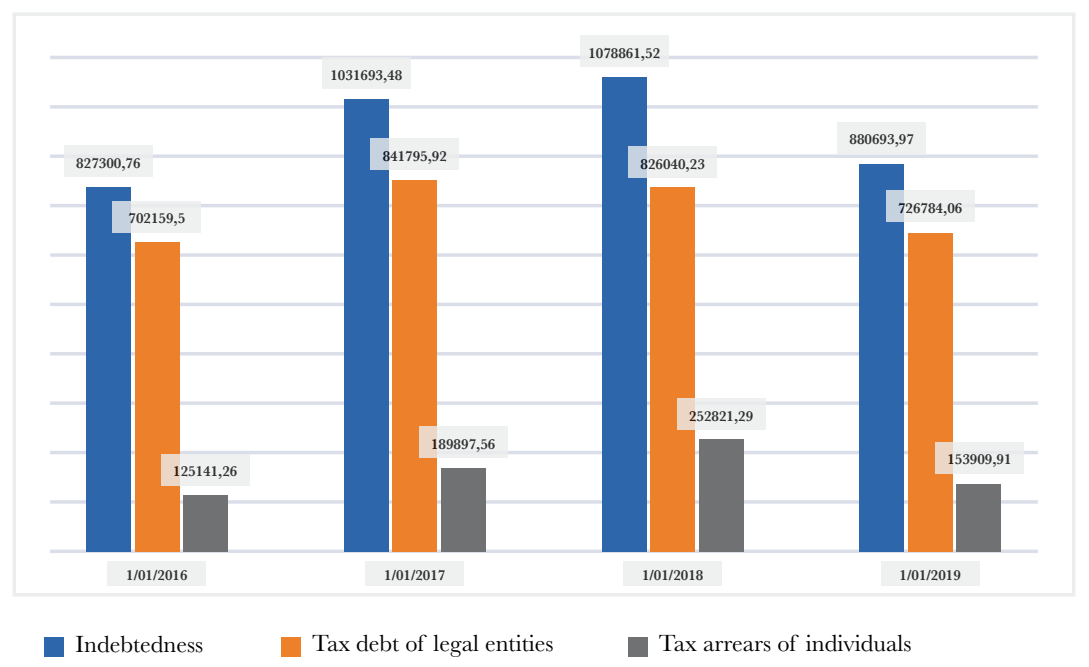

Picture 6. Dynamics of total tax debt in the whole of the Russian Federation.

The total tax debt in Russia increased by 30\% in 2017 compared to 2015. The main reason for the growth of aggregate tax debt is the additional charges on control work and crisis phenomena in the economy. The largest share in total tax debt is tax debt of legal entities - more than $75 \%$.

It should be noted that tax audits are not the cause of arrears, but only record the facts of violation of legislation on taxes and fees, as a result of which tax arrears of both legal entities and individuals arise. Conducting control measures in relation to taxpayers by the tax authorities does not always lead to the state budget receiving the full amount of taxes and fees, as reflected in the decision to prosecute tax violations. Such a result is possible if the organization does not have at the time of the control measures and after they have completed the property and current assets for repayment of the sums generated as a result of the audit.

To assess the effectiveness of the tax authorities, including tax control over the debt, the tax audit performance indicators and the amount of additionally accrued payments based on the results of tax audits (Table 1) (Orlova \& Kashapova, 2018) are used. 
Table 1. Dynamics of data on the results of tax audits in Russia.

\begin{tabular}{|c|c|c|c|c|}
\hline Indications & 2015 & 2016 & 2017 & 2018 \\
\hline \multicolumn{5}{|c|}{ Cameral tax audit } \\
\hline $\begin{array}{l}\text { The number of cameral } \\
\text { tax audits, in units }\end{array}$ & 31932225 & 39978278 & 55859670 & 67889196 \\
\hline $\begin{array}{l}\text { The number of cameral } \\
\text { tax audits that revealed } \\
\text { violations in units }\end{array}$ & 1948540 & 2254497 & 3014277 & 3531037 \\
\hline $\begin{array}{l}\text { The effectiveness of } \\
\text { cameral tax audits, in } \%\end{array}$ & 6,1 & 5,6 & 5,4 & 5,2 \\
\hline $\begin{array}{l}\text { Additionally accrued } \\
\text { payments, in thousand } \\
\text { rubles, of which: }\end{array}$ & 74233338 & 98491131 & 61559605 & 55659611 \\
\hline - Taxes & 60003911 & 73020626 & 41812328 & 36678972 \\
\hline \multicolumn{5}{|c|}{ Field Tax audit } \\
\hline $\begin{array}{l}\text { Number of field tax } \\
\text { audits, in units }\end{array}$ & 29393 & 24879 & 19391 & 13738 \\
\hline $\begin{array}{l}\text { The number of field tax } \\
\text { audits that revealed } \\
\text { violations in units. }\end{array}$ & 29118 & 24670 & 19134 & 13444 \\
\hline $\begin{array}{l}\text { The effectiveness of field } \\
\text { tax audits, in } \%\end{array}$ & 99,1 & 99,2 & 98,7 & 97,9 \\
\hline $\begin{array}{l}\text { Additionally accrued } \\
\text { payments, in thousand } \\
\text { rubles, of which: }\end{array}$ & 265239993 & 348632418 & 309863053 & 306199093 \\
\hline - Taxes & 195988031 & 251919710 & 221485332 & 2170984117 \\
\hline
\end{tabular}

The number of off-site tax audits significantly exceeds the number of on-site tax audits, respectively, the indicators of additionally accrued payments identified as a result of on-site tax audits are significantly higher than during the desk tax audits. This is due to the fact that the on-site tax audit allows tax authorities to verify various areas and aspects of taxpayers' activities. It is necessary to recognize that when conducting a field audit, the tax authorities have much more powers than the office audit. Upon completion of both the cameral tax audit and the on-site tax audit, the tax authorities are tasked with collecting the arrears, penalties and fines for them. But in practice, tax debt collection is not so easy.

\section{SUMMARY}

Having summarized the opinions of various economists, and, having analyzed the dynamics and structure of tax debts, we consider it possible to clarify the definition of tax debts from the point of view of its economic essence. Tax arrears 
can be defined as a set of unfulfilled obligations to pay the statutory taxes and fees, accrued penalties for late payment of taxes and fees, and awarded penalties for violating tax laws expressed in monetary form.

From the point of view of tax administration, it is necessary to clarify the definition of settled and unregulated tax arrears. Regulated tax debt is a debt with which the tax authority may conduct administrative measures (settlement methods), incl. change in the deadlines for the payment of taxes and other obligations (deferment, installment plan, investment tax credit), procedures of indisputable and compulsory collection, up to and including the initiation of a bankruptcy procedure and write-off. Unresolved tax arrears are arrears in respect of which indisputable penalties have not yet been applied, as well as uncollectible tax arrears, i.e. one that cannot be recovered due to certain circumstances and arrears. The proposed definitions of "settled, unresolved" debt should be consolidated legislatively, it will help to increase the tax discipline of tax payers.

Within the framework of the specifics of settled debt, it would be possible to suggest one more group of tax debts: tax debts, for which reconciliation of calculations was carried out and tax debts for which this reconciliation was not performed. In this regard, it is advisable to recommend adjusting the reconciliation of calculations with the budget at the level of the Tax Code of the Russian Federation, and not by-laws.

In conclusion, you can reflect the general model of tax debt for its various types (Picture 7). 


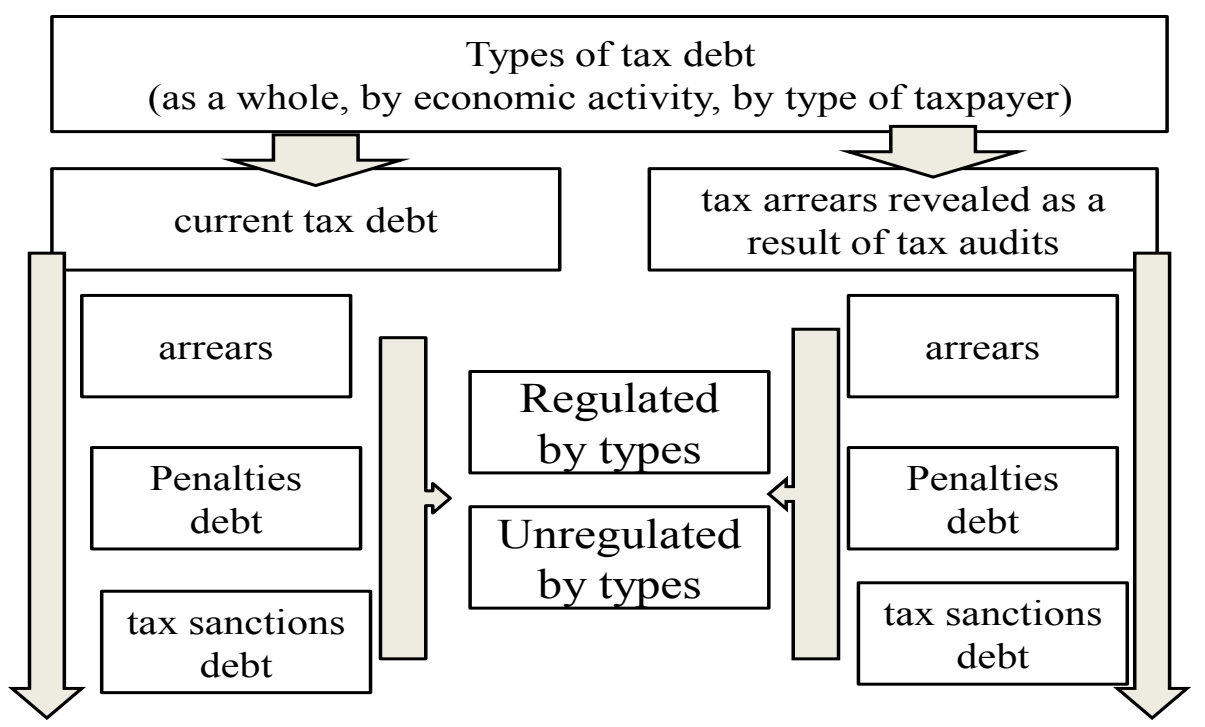

Picture 7. Classification of tax debt for tax administration purposes.

Interesting for tax administration purposes would be to use the tax debt classification by type of organizations-debtors, including by type of economic activity. This will improve the performance of the tax authorities to collect tax debts. It seems appropriate to develop a program of actions for administering different types of taxpayers and collecting tax arrears, and in the future, it is possible to prevent the occurrence of tax arrears.

\section{CONCLUSIONS}

In order to improve tax legislation and reduce tax debt, contributing to the development of tax control over debt, you can offer:

- To carry out bankruptcy prevention through the organization of financial monitoring of the state of affairs, both in each organization and the industry as a whole, developing a mechanism for crisis management, closing down unprofitable production and forecasting bankruptcies of insolvent and unprofitable organizations; 
- Tax authorities should be allowed to request documents from both taxpayers and counterparties outside tax audits in order to monitor the financial situation. Diagnosis of bankruptcy and crisis management will prevent the growing number of bankruptcies, will avoid the liquidation of many enterprises, which has a great influence on the level of tax debt in the Russian Federation as a whole;

- It is necessary to reduce the period of enforcement proceedings by bailiffs to 3 months, in order to improve the organization of interaction between tax authorities and the bailiff service and full control over the course of enforcement proceedings by tax authorities. Improving cooperation with the bailiff service will reduce the time needed to collect debts in the framework of enforcement proceedings and pay off taxpayers with debt from liquid assets in the course of enforcement proceedings.

Thus, the improvement of the mechanisms of tax authorities aimed at identifying tax debts becomes a very urgent task of tax legislation due to shortcomings that contribute to the growth of tax debts of both legal entities and individuals.

\section{ACKNOWLEDGEMENT}

The work is performed according to the Russian Government Program of Competitive Growth of Kazan Federal University.

\section{REFERENCES}

Aushev, T. A. (2004). Organizational and Economic Preconditions of Tax Debt and Ways to Reduce It.

Bondar, O. A. (2011). Cumulative tax liability: prerequisites and problems of its reduction. Power and Administration in the East of Russia, 1, 55-62.

Isaev, K. K. (2000). Reduction of Tax Payments of Enterprises in the Regional Economy. 
Lebedev, K. N. (1998). The concept, composition and legal regime of accounts payable. Economic Law, 11.

Official site of the Federal Tax Service of Russia. (2019). Statistics and analytics. Retrieved from http://nalog.ru

Orlova, M. E., \& Kashapova, R. R. (2018). Tax debt and its current status in Russia. Monthly International Scientific Fournal European Multi Science Fournal, 17, $39-46$.

Ozhegov, S. I. (1986). Dictionary of Ozhegov. Russian.

Pronin, S. B. (2016). Recovery of tax arrears from organizations. Accountant's Hotline, 9.

Raizberg, B. A., Lozovsky, L. Sh., \& Starodubtseva, Ye. B. (1999). Modern Economic Dictionary. INFRA-M.

Ushakov, D. N. (1935). Tolkovy Dictionary Ushakov. 


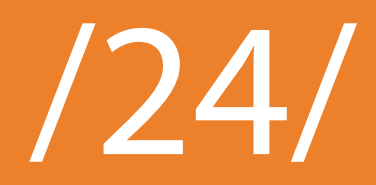




\section{TAX EXEMPTIONS FOR HEALTH CARE IN RUSSIA}

M.E. Orlova

Kazan Federal University, Institute of Management, Economics and Finance, Kazan, Russia

F.F. Adigamova

Kazan Federal University, Institute of Management, Economics and Finance, Kazan, Russia

V.I. Nasyrova

Kazan Federal University, Institute of Management, Economics and Finance,

Kazan, Russia

S.V. Salmina

Kazan Federal University, Institute of Management, Economics and Finance,

Kazan, Russia

E-mail: orlovamarina64@mail.ru

Recepción: 05/08/2019 Aceptación: 20/09/2019 Publicación: 23/10/2019

\section{Gitación sugerida:}

Orlova, M.E., Adigamova, F.F., Nasyrova, V.I. y Salmina, S.V. (2019). Tax exemptions for health care in Russia. 3C TIC. Cuadernos de desarrollo aplicados a las TIC. Edición Especial, Octubre 2019, 346-359. doi: https://doi.org/10.17993/3ctic.2019.83-2.346-359

Suggested citation:

Orlova, M.E., Adigamova, F.F., Nasyrova, V.I. \& Salmina, S.V. (2019). Tax exemptions for health care in Russia. 3C TIC. Cuadernos de desarrollo aplicados a las TIC. Special Issue, October 2019, 346-359. doi: https://doi.org/10.17993/3ctic.2019.83-2.346-359 


\section{ABSTRACT}

In Russia, much attention is paid to the development of the healthcare sector by providing financial direct and indirect support. The granting of tax preferences facilitates the activities of the institutions themselves, since this greatly alleviates the tax burden for them and ensures the inflow of capital and investment in this area. All this contributes to the development of the private medicine sector, increasing the cost of research and development related to health, which in turn brings benefits to the population. The main direction of application of preferences in the field of health care will contribute to the further development of the industry. The extension of the existing preferences, in particular on income taxes, which expires next year, may contribute to the development of both public and private health organizations. Of course, it's not about indefinite exemption from the tax, a developed practice is the establishment of a reduced tax calculation rate, with its subsequent gradual increase. This option is the most lenient for organizations, as a sharp transition from full tax exemption to calculating it at the maximum rate under normal conditions may entail a sharp increase in the tax burden, which can adversely affect the average and small health care businesses just starting its detail.

\section{KEYWORDS}

Taxation of health care facilities, Preferences for healthcare facilities, Value added tax preferences, Reduced social tax rates, Temporary tax preferences. 


\section{INTRODUCTION}

Public health and ensuring for it all the necessary conditions for the provision of health care services is one of the most important tasks of any state. The development of any of the areas, in particular health care, is impossible without government intervention. The need for continuous funding of organizations, investment in research and development requires considerable expenses.

Health care is divided into the public and private sectors, and if state organizations are financed by the state budget, the development of the private sector directly depends on many economic factors, one of which is taxation.

Trends in the change of healthcare institutions in Russia for the period from 2005 to 2016 are presented in Table 1.

Table 1. Dynamics of changes in the number of healthcare institutions in Russia from 2005 to 2016.

\begin{tabular}{|c|c|c|c|c|c|c|}
\cline { 2 - 7 } & 2005 & 2010 & 2013 & 2014 & 2015 & 2016 \\
\hline $\begin{array}{c}\text { The number of registered } \\
\text { medical organizations in } \\
\text { health care. }\end{array}$ & 36117 & 26174 & 25981 & 26987 & 27525 & 26556 \\
\hline $\begin{array}{c}\text { Of them: } \\
\text { Nongovernmental }\end{array}$ & 2934 & 2240 & 2338 & 2465 & 2459 & 2660 \\
\hline State & 33183 & 23219 & 23100 & 24056 & 24286 & 23091 \\
\hline
\end{tabular}

Source: (Russia in numbers, 2017).

Under the conditions of reforming the health care system for the period, the total number of health care institutions for the study period decreased by $26.4 \%$. Reduction occurred only in a group of government organizations.

Russia has three channels for financing health care institutions: budgetary, state medical insurance and extrabudgetary.

The health of certain groups of the population and the overall effectiveness of health care depend heavily on the method of financing the health system. The state provides the health care system with the necessary financial resources to provide the population with high-quality, affordable, timely medical care. On average, total government spending on health care amounts to $3.5 \%$ of GDP. 
Unfortunately, there is a decrease in this indicator. Unfortunately, there is a decrease in this indicator. Since the beginning of the reform of the health care system, budget expenditures for these purposes have been reduced by almost 100 billion rubles (from 401.1 billion in 2014 to 302.4 billion rubles in 2016) (Akishkin, 2014).

\section{METHODOLOGY}

In conducting the study, the methods of comparison and generalization, methods of statistical analysis and methods of analogy for determining risks were used.

\section{RESULTS AND DISCUSSION}

The nomenclature of health facilities was approved by the Ministry of Health of the Russian Federation on August 06, 2013. N. ${ }^{\circ}$ 529n. According to this nomenclature by type of activity medical organizations are divided into three large groups: treatment-and-prophylactic, organizations of a special type, organizations for supervision in the field of consumer protection. Each group has its own details, including from five to more than thirty institutions, each of which may specialize in a specific topic.

The preferential terms of application prescribed in the Tax Code of the Russian Federation, incl. tax rates, do not allocate with this separately taken types of institutions, and mainly apply to one or another type of there activity.

Health care institutions in Russia can use the general tax regime and the special tax regime in the form of a simplified tax system (Table 2). These are taxes for which no preference is provided.

Table 2. Dynamics of taxes paid by health care institutions, billion rubles.

\begin{tabular}{|c|c|c|c|c|c|c|c|c|}
\hline Year & $\begin{array}{l}\text { Income } \\
\operatorname{tax}\end{array}$ & $\begin{array}{l}\text { Personal } \\
\text { income } \\
\text { tax }\end{array}$ & VAT & $\begin{array}{l}\text { Excise } \\
\text { taxes }\end{array}$ & $\begin{array}{l}\text { Taxes on } \\
\text { the use } \\
\text { of natural } \\
\text { resources }\end{array}$ & $\begin{array}{l}\text { Property } \\
\text { tax }\end{array}$ & $\begin{array}{l}\text { Special tax } \\
\text { regime }\end{array}$ & $\begin{array}{c}\text { Social } \\
\text { contributions }\end{array}$ \\
\hline 2015 & 5,4 & 191,0 & 8,50 & 0 & 0,03 & 9,95 & 5,60 & no data \\
\hline 2016 & 5,4 & 191,0 & 8,50 & 0,01 & 0,03 & 9,95 & 5,60 & no data \\
\hline
\end{tabular}




\begin{tabular}{|c|c|c|c|c|c|c|c|c|}
\hline Year & $\begin{array}{c}\text { Income } \\
\text { tax }\end{array}$ & $\begin{array}{l}\text { Personal } \\
\text { income } \\
\text { tax }\end{array}$ & VAT & $\begin{array}{c}\text { Excise } \\
\text { taxes }\end{array}$ & $\begin{array}{l}\text { Taxes on } \\
\text { the use } \\
\text { of natural } \\
\text { resources }\end{array}$ & $\begin{array}{l}\text { Property } \\
\text { tax }\end{array}$ & $\begin{array}{l}\text { Special tax } \\
\text { regime }\end{array}$ & $\begin{array}{c}\text { Social } \\
\text { contributions }\end{array}$ \\
\hline 2017 & 4,5 & 5, 209 & 8,10 & 0,00 & 0,03 & 7,70 & 7,00 & 435,00 \\
\hline 2018 & 5,0 & 256,8 & 8,90 & 0,00 & 0,03 & 7,90 & 8,70 & 532,80 \\
\hline $\begin{array}{c}2018, \\
\%\end{array}$ & 0,7 & 30,5 & 1,1 & 0 & 0 & 3,5 & 1,1 & 63,2 \\
\hline
\end{tabular}

Source: (Ponyuhov, 2016).

If state organizations are financed by the state budget, the development of the private sector directly depends on many economic factors, one of which is taxation Health care is an industry in which the main burden falls on the wage fund, more than $60 \%$.

The main preferences provided for health organizations relate to VAT and income tax. In certain regions of the Russian Federation privileges on property tax may be established.

Table 3. Tax preferences for health organizations.

\begin{tabular}{|c|c|c|}
\hline TAX & $\begin{array}{c}\text { Types of medical and health } \\
\text { organizations }\end{array}$ & Preferences \\
\hline $\begin{array}{l}\text { Income } \\
\operatorname{tax}\end{array}$ & $\begin{array}{l}\text { State, municipal } \\
\text { and private medical } \\
\text { and health organizations }\end{array}$ & $\begin{array}{c}\text { Art. } 251 \text { of the Tax Code of the Russian Federation - non- } \\
\text { taxable income } \\
\text { Art. } 284.1 \text { of the Tax Code of the Russian Federation - } \\
\text { application of the Oth rate }\end{array}$ \\
\hline VAT & $\begin{array}{l}\text { State, municipal } \\
\text { and private medical } \\
\text { and health organizations }\end{array}$ & $\begin{array}{l}\text { Art. } 145 \text { of the Tax Code of the Russian Federation - full } \\
\text { exemption from VAT } \\
\begin{array}{c}\text { Art. } 149 \text { of the Tax Code of the Russian Federation - (paragraph } \\
2 \text { of paragraphs 1,2) exemption from taxation of certain } \\
\text { operations. }\end{array} \\
\begin{array}{c}\text { Art. } 164 \text { of the Tax Code of the Russian Federation (clause 2, } \\
\text { clause } 4 \text { ) -application of a reduced rate of } 10 \% \text { on VAT }\end{array}\end{array}$ \\
\hline $\begin{array}{l}\text { Property } \\
\operatorname{tax}\end{array}$ & $\begin{array}{l}\text { State, municipal } \\
\text { and private medical } \\
\text { and health organizations }\end{array}$ & Tax legislation of the subjects of Russia \\
\hline Land tax & $\begin{array}{l}\text { State, municipal } \\
\text { and private medical } \\
\text { and health organizations }\end{array}$ & Decisions of municipal representative bodies \\
\hline $\begin{array}{l}\text { Transport } \\
\operatorname{tax}\end{array}$ & $\begin{array}{l}\text { State, municipal } \\
\text { and private medical } \\
\text { and health organizations }\end{array}$ & Tax legislation of the subjects of Russia \\
\hline
\end{tabular}

Source: Tax Code of Russia (Tax Code (Part I) of the Russian Federation of July 31, 1998; Tax Code (Part II) of August 5, 2000). 
A change in the established tax rates for individual taxes and taxpayers, whether on an urgent or a perpetual basis, can either increase interest in a particular area or restrain its development, if necessary. Since the subject of our research is healthcare institutions and their activities, let us consider what kind of "relief" the legislator provides for this category of taxpayers.

One cannot but agree with the opinion of the researchers that the development of tax preferences is necessary not only for the health care organizations themselves, but also for private investors in this field (Dadashev, Meshkova, \& Topchi, 2016). For Russia, at present, the use of aggressive tax optimization methods is questionable. Moreover, the institution receives an additional competitive advantage as a bona fide taxpayer (Retz, 2015). When applying the tax preferences of a health care institution, in order to minimize the risks of violating tax laws and holding them accountable, they must maintain internal tax control over the implementation of the established framework for the use of benefits (Ponyuhov, 2016).

The preferences for the value added tax in the field of health care are associated with the exemption from taxation of certain operations and the implementation of the conditions for their use established in paragraph 2 of Article 149 of the Tax Code of Russia. Growth of falling incomes of the budget on the VAT in the field of public health services is observed. At the same time, the number of declarations in which this preference is declared is decreasing.. (Picture 1).

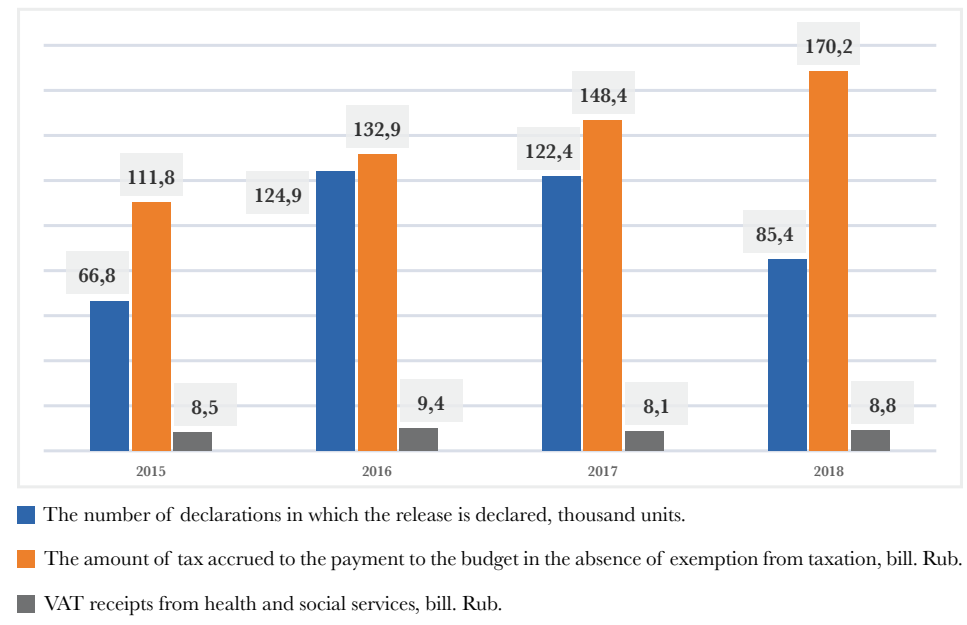

Picture 1. Dynamics of shortfall in income on VAT on health care institutions and tax returns. Source: (Ponyuhov, 2016). 
According to a number of specialists in the field of organization and economics of health care, the current exemption of medical services from VAT is essentially no incentive for the development of entrepreneurship in health care and, at the same time, does not have any impact on the financial situation of medical organizations. According to experts, with the help of these tax benefits, the state is trying to limit the prices of paid medical services. And this is beneficial, first, to consumers, that is, patients, which, of course, cannot be regarded as an exclusively positive point in the practice of taxation (Podogova \& Orlova, 2018).

Tax preferences for VAT exceed the actually received VAT from the health care industry by 19 times. Russian health care institutions are actively using the right to association. Based on the statistical reporting data of the Federal Tax Service of Russia, the dynamics of tax expenditures, when applying VAT exemptions for medical goods and services, health services are presented in the Picture 2.

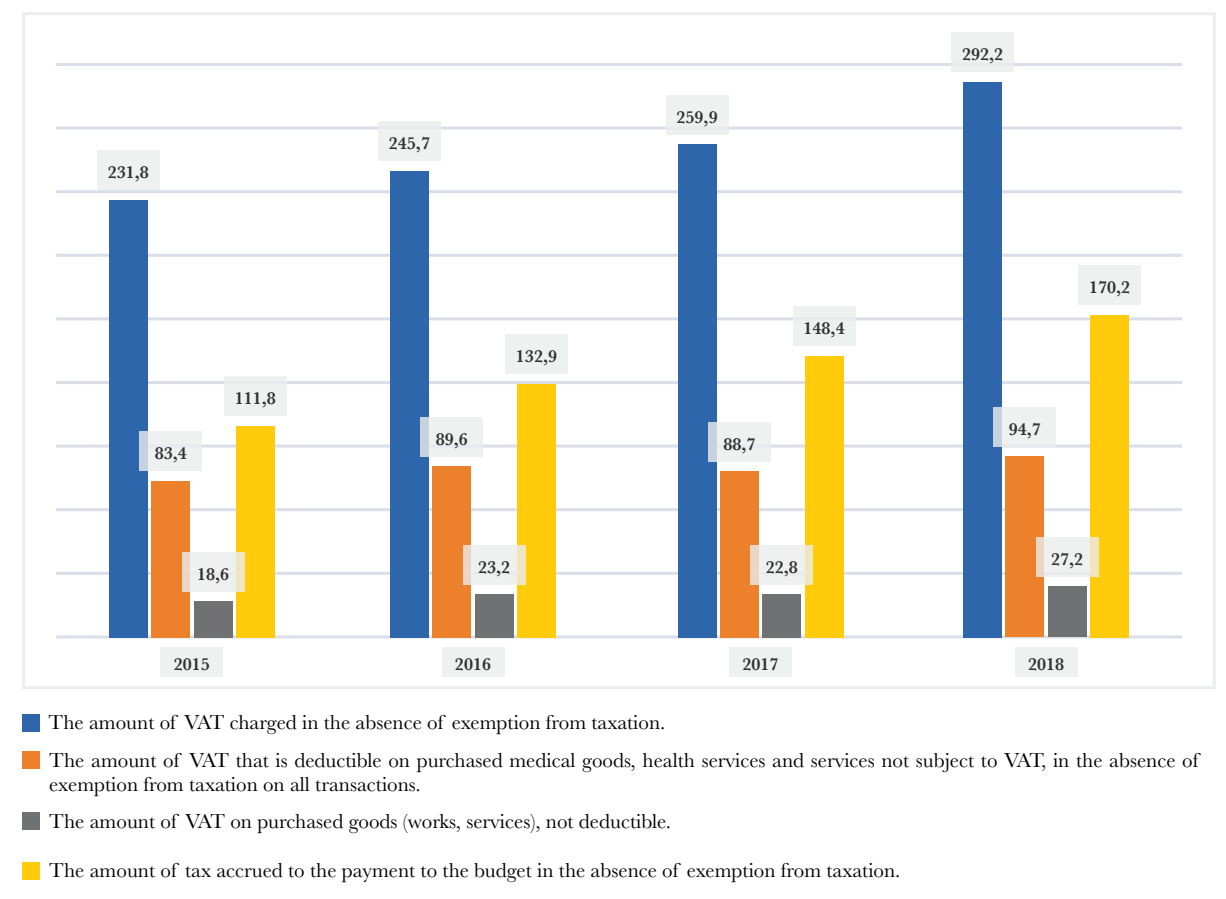

Picture 2. The dynamics of falling budget revenues in connection with the application of exemptions by health care institutions under paragraph 2 of Art. 149 TC RF, bill. Rub. Source: (Ponyuhov, 2016). 
Preferences are offered for health care facilities and for income tax. According to clause 1.1 of Article 284 of the Tax Code of the Russian Federation, organizations engaged in medical activities have the right to apply a tax rate of $0 \%$ on income tax for the period from January 1, 2011 to January 1, 2020. Established the need to comply with certain conditions: the availability of a license, the compliance of the services provided to the established list of operations and separate accounting (Tax Code (Part II) of August 5, 2000). The possibility of applying the $0 \%$ tax rate is provided when performing the following procedures: notifying the tax authority of this preference application, license availability, compliance of the services provided to the established list of operations, income from medical activities more than $90 \%$, at least 15 employees, $50 \%$ and more work continuously in the state certified specialist (Tax Code (Part II) of August 5, 2000).

Until 2019, social tax preferences were established. For example, organizations engaged in the production of medicines, medical instruments and equipment, carrying out activities in the field of health care, as well as pharmacies, single tax payers with no imputed income, had the right to apply a lower insurance premium rate for the period 2017-2018. This preference exempted them from paying contributions to compulsory medical and social insurance funds and reduced the rate for contributions to the pension insurance fund from $22 \%$ to $20 \%$.

\section{SUMMARY}

The provision of preferences for one of the most important taxes, the rates for which are quite high (value added tax - 20\% from 2019, corporate income tax - $20 \%$, insurance premiums at the basic rate - $30 \%$ of wages), provides milder operating conditions and has a positive impact on the health sector, ensuring growth in investment, capital inflows and a growing number of non-governmental institutions. 
Table 4. The number of health organizations in the period 2014-2016.

\begin{tabular}{|c|c|c|c|}
\hline Year & $\begin{array}{c}\text { Total } \\
\text { number of health } \\
\text { organizations, th. }\end{array}$ & $\begin{array}{c}\text { Number of private health } \\
\text { organizations, th. }\end{array}$ & $\begin{array}{c}\text { The share of private health } \\
\text { organizations in the total, } \%\end{array}$ \\
\hline 2014 & 83,2 & 51,4 & 61,7 \\
\hline 2015 & 86,0 & 55,1 & 64,0 \\
\hline 2016 & 85,9 & 56,5 & 65,8 \\
\hline
\end{tabular}

Source: (Russia in numbers, 2018).

During the period under review, the number of nongovernmental organizations in the health sector increased by $10 \%$. The trend of growth of this indicator is observed at the present time, despite the fact that the total number of health care organizations is declining: in 2017 their number decreased compared to 2016 by $6.6 \%$ and amounted to 80.3 thousand.

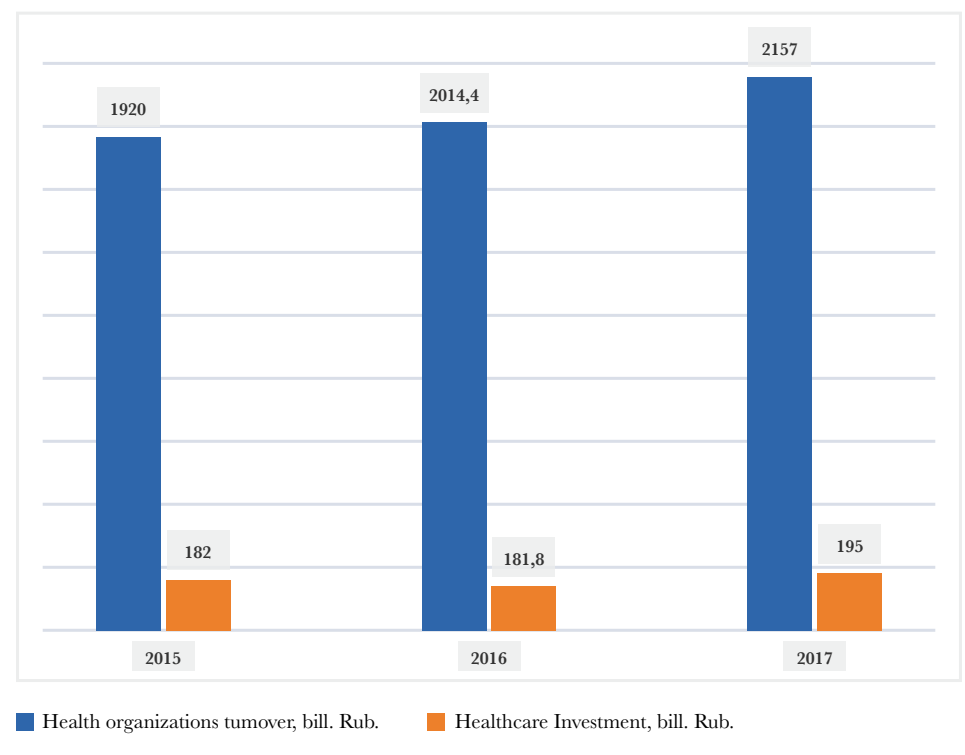

Picture 3. Service revenue of organizations and investments in fixed assets in the field of health. Source: (Russia in numbers, 2018; Russia in numbers, 2017).

There is a tendency of growth at once on two indicators: turnover of organizations and investments made in fixed assets. In the period from 2015 on 2017 turnover of health organizations increased by $12 \%$, and investment in fixed assets in the field by $7 \%$. At the same time, given that the overall growth rate of investment in 
all areas in 2017. in relation to the indicators of 2016 . increased by only $4.2 \%$; an increase in investment separately in the healthcare sector by $7 \%$ is a good indicator.

Another confirmation of the active development of the health sector in recent years is also the fact that the cost of research and development in the direction of "protecting the health of the population" over the past 10 years has doubled, reaching in 2017. 30.5 billion rubles (Russian statistical yearbook, 2018, c.485). Comparing the figures we cited, especially the amount of investments and turnover of organizations for the period 2015-2017, we can say that the provision of tax preferences in the health sector gives a positive result.

Providing this kind of preferences for exemption from tax payment or the use of a reduced rate when calculating it is, undoubtedly, a kind of support for organizations, but for the state this means under-received funds to the budget. That is why most of the preferences listed by us are temporary: the application of the reduced tariff on insurance premiums has not been implemented since 2019, the application of the $0 \%$ rate on income tax is limited to 2020 .

The abolition of the preferences provided is natural, since initially their introduction provides for a temporary nature. However, the health care sector is not the sector that can have priority in development today, but tomorrow it will give way to the production or services sector. As mentioned earlier, the health sector is always one of the most important for its maintenance and development.

\section{CONCLUSIONS}

Based on illustrative examples, based on official statistics, we can assume that the extension of the existing preferences, in particular on income taxes, which expires next year, may contribute to the development of both public and private health organizations. Of course, we are not talking about indefinite exemption from the tax, a developed practice is the establishment of a reduced tax calculation rate, with its subsequent gradual increase. This option is the most lenient for 
organizations, as a sharp transition from full tax exemption to calculating it at the maximum rate under normal conditions may entail a sharp increase in the tax burden, which can adversely affect the average and small health care businesses just starting its detail.

As a result of the study, the following problems were identified:

- Lack of reporting on the assessment of the effectiveness of tax preferences for health care organizations;

- Tax preferences for organizations carrying out scientific research in the field of medicine and health care are not enough.

In order to solve the first problem, we recommend using the criteria for evaluating the efficiency of tax benefits of health care institutions: an increase in the cost of equipment (technical base) of a medical organization, an increase in the indicators of high-tech medical care, an increase in the indicators of medical care in nosology and introduce appropriate reporting from health organizations.

To solve the problems of the second group, it is advisable to introduce tax holidays for VAT and income tax for companies implementing new medical equipment, VAT and income tax for companies that are developing new drugs, property tax for healthcare organizations carrying out introduction of new development of equipment for medicine.

\section{ACKNOWLEDGEMENT}

The work is performed according to the Russian Government Program of Competitive Growth of Kazan Federal University. 


\section{REFERENCES}

Akishkin, V. G. (2014). Regional Health Care in the Context of Institutional Transformations: The Economic and Financial Aspect: Monograph. Volgograd: Volgograd scientific ed.

Dadashev, A. Z., Meshkova, D. A., \& Topchi, Y. A. (2016). Development of the financial mechanism and taxation of social organizations. Finance and Credit, 2-14.

Podogova, D., \& Orlova, M. (2018). Improving the conditions of taxation of medical and health organizations in Russia. International science project, 19, 49.

Ponyuhov, E. V. (2016). Internal Control as a Factor in Reducing Tax Risks in Healthcare Institutions. Saint-Petersburg State Economic University.

Retz, V. V. (2015). Ways to Optimize the Taxation of Autonomous Institutions. News of the Russian Economic University.

Russia in numbers. (2017). Federal State Statistics Service. Retrieved from http:// www.gks.ru/free_doc/doc_2017/rusfig/rus17.pdf

Russia in numbers. (2018). Federal State Statistics Service. Retrieved from http:// www.gks.ru/free_doc/doc_2018/rusfig/rus18.pdf/

Russian statistical yearbook. (2018). Federal State Statistics Service. Retrieved from http://www.gks.ru/free_doc/doc_2018/year/year18.pdf/

Statistics and Analytics of the Federal Tax Service of Russia. Retrieved from https: / / www. nalog.ru/rn16/related_activities/statistics_and_analytics/forms/6911382/

Tax Code (Part I) of the Russian Federation. (July 31, 1998). N. ${ }^{\circ} 146$ - FZ. Collected Legislation of the Russian Federation. N. ${ }^{\circ}$ 31, art. 3824.

Tax Code (Part II) of the Russian Federation. (August 5, 2000). N. ${ }^{\circ} 117$ - FZ. Collected Legislation of the Russian Federation. N. ${ }^{\circ}$ 32, art. 3340. 
Edición Especial Special Issue Octubre 2019 DOI: https://doi.org/10.17993/3ctic.2019.83-2.346-359 


$$
\text { /25/ }
$$




\section{THEORETICAL ASPECTS OF TOURISM ATTRACTIVENESS AND ITS ESTIMATION BY THE EXAMPLE OF THE REPUBLIC OF TATARSTAN}

Gulnara Faridovna Valeeva

Kazan Federal University Institute of Management, Economics and Finance,

Kazan, Russia

Oleg Aleksandrovich Bunakov

Kazan Federal University Institute of Management, Economics and Finance,

Kazan, Russia

Boris Moishevich Eidelman

Kazan Federal University Institute of Management, Economics and Finance,

Kazan, Russia

Liliya Raisovna Fakhrutdinova

Kazan Federal University Institute of Management, Economics and Finance,

Kazan, Russia

E-mail: gfvaleeva@gmail.com

Recepción: 05/08/2019 Aceptación: 20/09/2019 Publicación: 23/10/2019

Gitación sugerida:

Valeeva, G.F., Bunakov, O.A., Eidelman, B.M. y Fakhrutdinova, L.R. (2019). Theoretical aspects of tourism attractiveness and its estimation by the example of the Republic of Tatarstan. 3C TIC. Cuadernos de desarrollo aplicados a las TIC. Edición Especial, Octubre 2019, 360-373. doi: https://doi.org/10.17993/3ctic.2019.83-2.360-373

Suggested citation:

Valeeva, G.F., Bunakov, O.A., Eidelman, B.M. \& Fakhrutdinova, L.R. (2019). Theoretical aspects of tourism attractiveness and its estimation by the example of the Republic of Tatarstan. 3C TIC. Cuadernos de desarrollo aplicados a las TIC. Special Issue, October 2019, 360-373. doi: https://doi.org/10.17993/3ctic.2019.83-2.360-373 


\section{ABSTRACT}

The article presents the analysis of theoretical approaches to the study of a tourism attractiveness of the region and its elements. Tourism attractiveness of the region is defined as a multi-layered concept reflecting the totality of the subjective and objective characteristics of the region that influence the results of tourist activities and determine the position of the region for the subjects of tourist activities. Presently, the tourism industry is one of the most significant sectors in the development of the region: being aware of it, the state promotes the formation and development of tourism and provides a supportive environment for its development, thereby ensuring the implementation of socially-oriented functions. The management practice of developing the tourism attractiveness of Russian regions should take account of the commercial interests of various business areas, the priorities of state policy and the cultural needs of society. In order to strengthen the tourism appeal, the regions include the development of a set of various actions into the agenda, one of the keys is to form a positive attitude towards the territory and its recognition - regional branding. The Republic of Tatarstan is one of the most promising tourist centers of Russia which actively develops the tourism sector and increases its quantitative indicators and implements large-scale and ambitious projects that improve the tourist attraction.

\section{KEYWORDS}

Tourism, Tourism attractiveness, Region, Regional development, Branding. 


\section{INTRODUCTION}

Today, tourism industry as a highly remunerative and fastest growing economic realm takes on greater and greater importance in the development of individual regions, contributing to the preservation of social and cultural potential and authentic values, natural landscapes and ecosystems of various territories. Being a relatively independent industry, the tourism industry provides a deep integration of social relation and social mobility. Currently in Russia, the tourism industry is at the stage of institutional formation and structural modernization of the tourism infrastructure, the formation of a stable basis for inter-sectoral interaction.

\section{METHODOLOGY}

The methodological framework of the research is represented by a systematic approach to the study of tourism appeal, its elements in their interconnection and interdependence, the method of analysis and synthesis of legal and scientific literature, statistical data.

\section{RESULTS AND DISCUSSION}

The treatment of the essence of the concept "tourism appeal of the regions" should be explored by a multi-stage approach, which includes the study of the following concepts: "tourism", "tourism attractiveness" and "tourism attractiveness of the region".

Exploring the concept of "tourism", we can single out the basic definitions that most fully describe this field of activity.

Buzulukova considers tourism as a temporary movement of people in their free time for recreation, health-improving, educational or business purposes but if they have no work to be paid. 
Glagoleva outlines the definition briefly, thereby revealing the basic essence of the concept, that is, tourism is the departure of a consumer of travel services, not related to extraction of profit.

Kabirov (2016) treats tourism as a set of relationships and services that are associated with a voluntary and temporary change of residence by a traveler for non-professional or non-commercial reasons.

Motyshina in her writings speaks of the essence of tourism more broadly, arguing that it is an economic system with various links between individual elements within the framework of tourist activities.

Rozanova in her writings points to a spiritual part of the tourist sphere, considering tourism as a method of cognition by society of the natural resources and cultural wealth created by nature and humanity.

Sukhanova interprets tourism as a rather complex and multifaceted phenomenon, including social practice, leisure, a special form of consumption, a major cultural phenomenon.

Making a summary of these terms, the concept of "tourism" can be defined as a complex and multifaceted phenomenon, which encapsulates a variety of social relations arising between a large number of subjects and objects in the field of tourism, the consumers of which are the individuals who temporarily change their place of residence in order to have a rest.

The study of the concept of tourism appeal is based on the analysis of the following definitions:

Kalashnikova \& Khanakhok (2015) define tourism attractiveness as a complex activity reflecting travel package, potential, destination culture, tourist place and other industry indicators.

Neterin (2018) considers tourism attractiveness through the lens of the relationship between possible and existing elements and tourist demand. 
As a result, it is possible to put these concepts together and formulate a comprehensive definition of tourism attractiveness as one based on the analysis of the presence of a possible adequate tourism offer, the ability of an object of the sphere of tourism to attract positive attention, to generate interest and repeated demand:

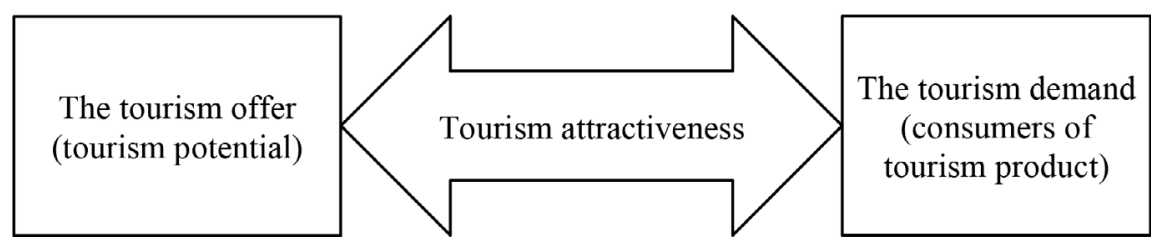

Figure 1. The Essence of the Concept "Tourism Attractiveness".

The concept of tourism attractiveness is considered by many authors in the context of territories, therefore, it is further expedient to explore the essence of the concept of region's tourism appeal.

Likhanina in her works considers tourism attractiveness in relation to the territorial aspect, claiming that it is an element of the competitiveness of the region, its brand and investment potential.

Bunakov (2016) forms the concept of tourism attractiveness of the territory through estimating by potential tourists the ability of the region to meet their needs for recreational, medical and health, professional and business, educational, physical culture and sports, religious and other purposes.

Cheberko interprets tourism appeal of the territory as a combination of various factors that contribute to its high competitiveness in the struggle of tourists of various target groups.

Thus, the tourism attractiveness of the region is a multidimensional concept that reflects the totality of its subjective and objective characteristics affecting the results of tourist activities, and subsequently determining the position of the region for various subjects of touristic activities (considering the resource and infrastructure potential, as well as social institutional risks). 
The role and relationship of tourism attractiveness of the region with elements of regional development is presented schematically in Figure 2:

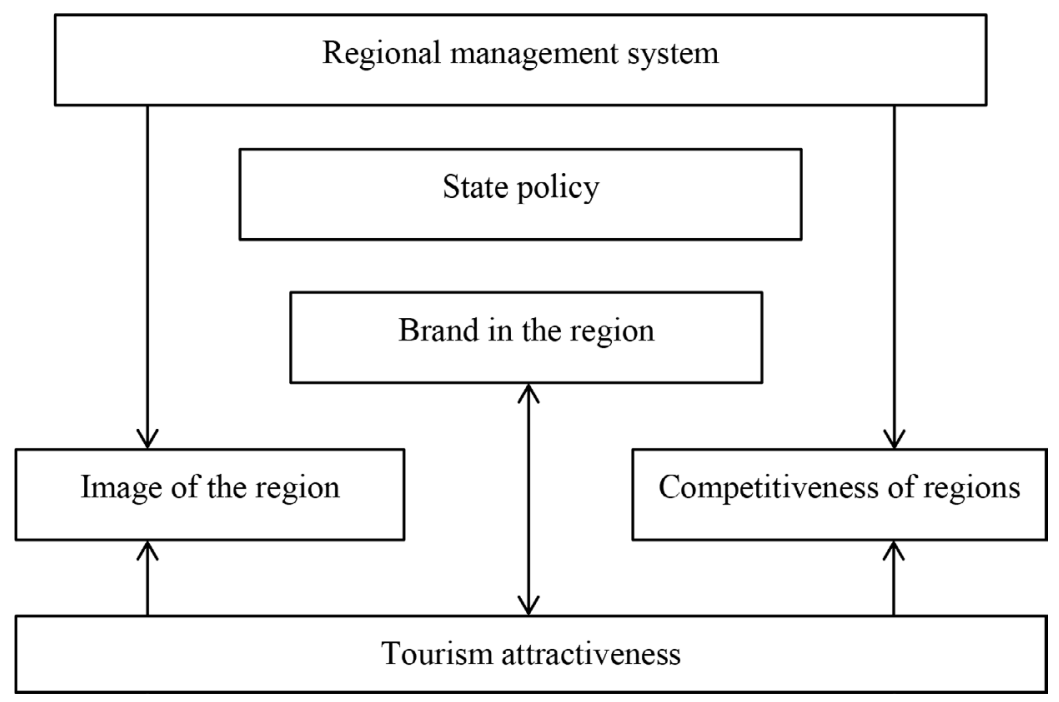

Figure 2. Tourism Attractiveness in Regional Management System. Source: (Tsurtsilina, 2016).

Being a subject of management, the state should recognize the tourism industry as one of the leading sectors of regional development, promote the formation of tourism throughout the territory and create the mechanisms for its effective development.

The formation and development of the tourism appeal of the region is the activity of management entities concerning the determination, generation and achievement of certain objectives and indicators that influence the results of the tourism industry and estimate the rating of the region for the subjects of tourism activity.

Today, in order to develop tourism, any territory includes the elaboration of various activities to the development plan, of which the formation of a positive attitude towards the territory and its recognition - regional branding - grows in popularity. Positioning a positive image of the territory, which is based on the uniqueness of the tourist object, becomes the actual principle of the formation and development of the branded tourist territory (Eidelman et al., 2018). 
The purpose of managing the development of tourism attractiveness of the territory is the formation, generation and development of territorial branding, which is revealed in the formation of competitive or special advantages of a particular region over other regions, as well as the improvement of its image as a tourist destination. The main task in managing the development of tourism appeal of the territory is the creation of such conditions that will attract potential consumers of travel services by increasing in the tourist flow in general.

Strengthening the tourism appeal of the Russian regions includes the areas on which the mechanisms of influence of management practices are oriented, both from the state and regional commercial enterprises. Let us represent the main types of development factors for management practices of improving on Russian regions' image as a tourist destination:

- Creation of tourism image;

- Development of sports, event, conference and business tourism;

- Expansion of recreational potential;

- Development of accommodation business;

- Improvement of tourist-excursion service and transport service;

- Innovations in the field of entertainment.

Currently, in Russia there is a state project "The Strategy for the Development of Tourism in the Russian Federation for the Period up to 2020", which is a driver in the development of territories and the link between the three parties concerned:

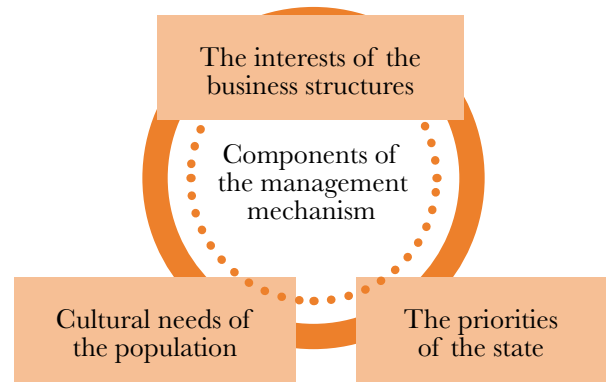

Figure 3. Interrelated Parties in the Management Practice of Strengthening the Tourism Attractiveness of the Russian Regions. 
The management practice of strengthening the tourism appeal of the Russian regions should consider the commercial interests of various business structures, the priorities of the state policy and cultural needs of the society.

The Republic of Tatarstan is one of the most vibrant regions of the Russian Federation in relation to economics and tourism. In terms of gross regional product, the Republic of Tatarstan ranks 6th among the regions of Russia (in 2018 it amounted to 2115.5 billion rubles, or $102.8 \%$ in comparable prices to the level of 2017). The main contribution to economic growth was made by industrial production, agriculture and trade.

The share of the tourism industry in the total structure of the gross regional product of the Republic of Tatarstan for 2018 was $6.1 \%$, the value of the share of the tourism industry for the previous periods did not significantly change (Berdnikova \& Ivanov, 2015).

The tourism attractiveness of the Republic of Tatarstan is constantly strengthened, for example, for a number of previous years large-scale and ambitious projects that contributed to attracting the flow of tourists to the region has been implemented.

Firstly, these are the projects and programs for the revival and preservation of historical and cultural heritage in order to develop tourism and pilgrimage (the city of Bolgar and the island city of Sviyazhsk, holding the 1000th anniversary of Kazan in 2005 and the city of Yelabuga in 2007). Historical sights were also restored, new objects of culture and infrastructure were built. Kazan hosted such major events as the 27th World Summer Universiade in 2013, the World Aquatics Championship in 2015, the Confederation Cup in 2017, the World Football Championship in 2018. New tourist routes and destinations have been opened which are successfully developing and are associated with rural environmental, sports and event, gastronomic, medical, ethnographic and halal tourisms (Eidelman et al., 2018; Niyaz et al., 2018; Bunakov \& Rubtzov, 2016). 
Secondly, these are the programs aimed at creating an innovation infrastructure within the framework of developing business (industrial) tourism. It is worth noting the construction of Russia's largest special economic zone "Alabuga" in 2006, the creation of the city of Innopolis in 2015, the construction of the international investment Technopolis "SMART City Kazan".

Today, the Republic of Tatarstan is one of the most promising tourist centers of Russia. Tourist flow to the republic increases on average by $8 \%$ per year, and by 2019, an increase up to 2 million 450 thousand people is predicted. The income of collective accommodation facilities from the rendered services in 2018 amounted to 8.7 billion rubles, which is $31.5 \%$ more than in the same period of 2017. According to the results of the rating of Russian regions for the growth of income of hotels and similar accommodation facilities over the past 10 years, the rating of Tatarstan has risen from the 12th place to the 4th one. The number of foreign citizens arriving in the republic has increased by $24.3 \%$, compared to 2017:

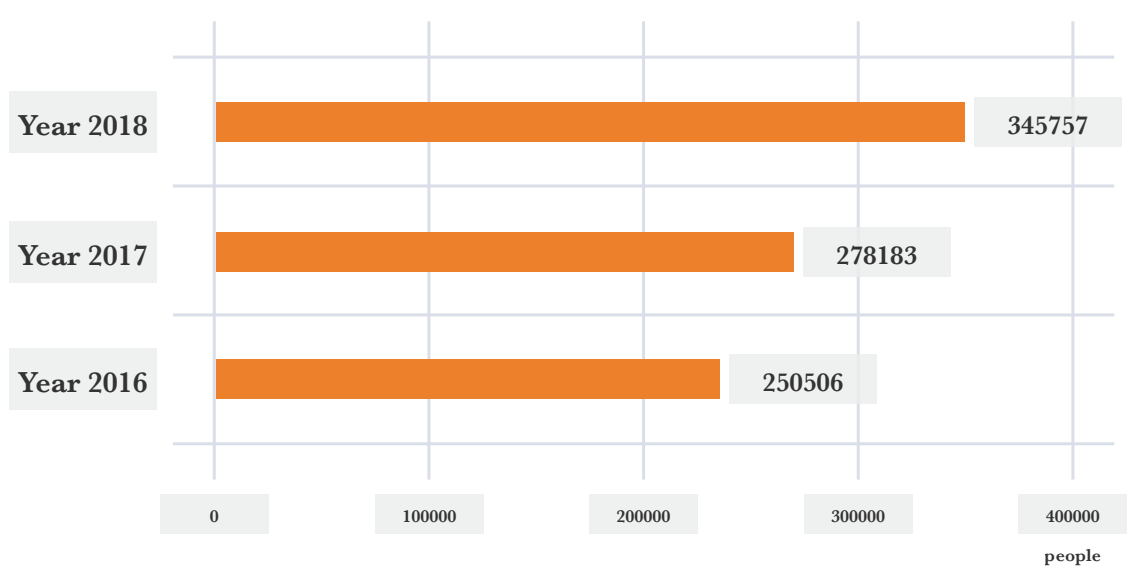

Figure 4. The Number of Foreign Citizens Who Arrived in the Republic of Tatarstan in 2016-2018.

The dynamics of the number of guests of the Republic of Tatarstan who were placed in collective accommodation facilities is presented in the table: 
Table 1. The Dynamics of the Number of Persons Placed in Collective Accommodation Facilities Showing the Target Groups, Thousand People.

\begin{tabular}{|c|c|c|c|c|c|c|}
\hline Name & $\begin{array}{l}\text { Year } \\
2014\end{array}$ & $\begin{array}{l}\text { Year } \\
2015\end{array}$ & $\begin{array}{l}\text { Year } \\
2016\end{array}$ & $\begin{array}{l}\text { Year } \\
2017\end{array}$ & $\begin{array}{l}\text { Year } \\
2018\end{array}$ & $\begin{array}{l}\text { Change in } \\
2018 \text { to } \\
2014 ., \%\end{array}$ \\
\hline $\begin{array}{l}\text { Number of persons served } \\
\text { by collective accommodation } \\
\text { facilities, including }\end{array}$ & 1759,1 & 1782,4 & 1861,2 & 2096 & 2311,1 & 131,4 \\
\hline $\begin{array}{l}\text {-for business, educational and } \\
\text { professional purposes }\end{array}$ & 557,4 & 533,4 & 653,6 & 765,3 & 851,6 & 152,8 \\
\hline $\begin{array}{l}\text { - for the purpose of leisure, } \\
\text { recreation, vacation }\end{array}$ & 733,7 & 855,2 & 947,4 & 1096,6 & 1206,2 & 164,4 \\
\hline - for treatment and prevention & 140,3 & 136,6 & 153,7 & 151,3 & 162,7 & 116,0 \\
\hline - etc. & 327,7 & 227,2 & 106,5 & 82,8 & 90,6 & 27,6 \\
\hline
\end{tabular}

Most tourists visit the republic for the purpose of leisure activity, recreation, vacation, as well as for business reasons. In 2018, the number of guests who visited the Republic of Tatarstan for tourism purposes amounted to 2,311.1 thousand people, which is $131.4 \%$ more than in 2014 .

The structure of the tourists of the Republic of Tatarstan according to the purpose of the trip for 2018 is presented in Figure 5:

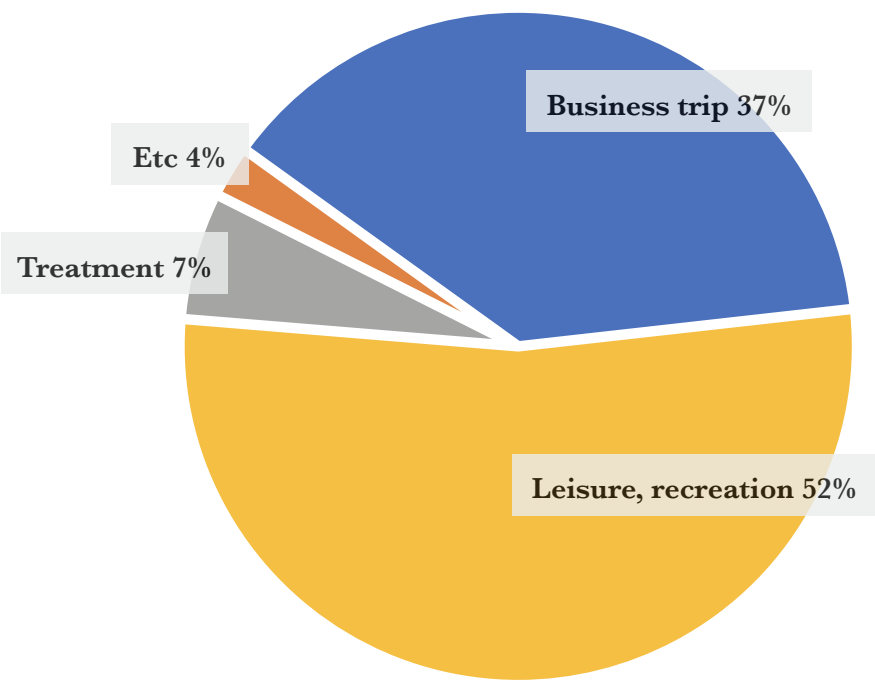

Figure 5. The Structure of Tourists of the Republic of Tatarstan According to the Purpose of the Trip for 2018. 


\section{SUMMARY}

The tourism potential of the Republic of Tatarstan characterized by a combination of great history and rich culture of the East and West, Islam and Orthodoxy, a good geographical location and national distinctive features should be focused on the development of all areas of tourism that can give a significant economic effect. Maintaining and increasing the pace of tourism development in the Republic of Tatarstan today is the most important strategic task of all participants of the tourism market, as the tourism brand of Tatarstan contributes to strengthening competitive positions, attracting investors, expanding the network of travel business and developing the entire tourist industry on the whole.

\section{CONCLUSIONS}

The issues of tourism draw of the regions today are an important aspect of regional development, this is due to its influence on regional socio-economic development, one of the key indicators of which is the gross regional product. The Republic of Tatarstan is one of the most effective and successful regions of Russia in the formation and development of travel industry. Being an economically prosperous region, Tatarstan is constantly enhancing its competitive advantages in the tourism industry by holding large-scale events on forming tourist loyalty, building new demonstration facilities, places and destinations that help attract tourist flows.

\section{ACKNOWLEDGEMENTS}

The work is performed according to the Russian Government Program of Competitive Growth of Kazan Federal University. 


\section{REFERENCES}

Berdnikova, O. A., \& Ivanov, S. E. (2015). Analysis and Dynamics of the Indicators of Tourism Development Using the Republic of Tatarstan as an Example. The Age of Quality, 1, 73-76.

Bunakov, O. A. (2016). Development of tourism in the region on the basis of cluster approach. International Business Management, 10(21), 5104-5106.

Bunakov, O. A., \& Rubtzov, V. A. (2016). Complexity of positioning in tourism as the basis of its sustainable development. International Business Management, 10(21), 5101-5103.

Eidelman, B. M., Bunakov, O. A., Nayda, A. M., Fakhrutdinova, L. R., \& Gabdrakhmanov, N. K. (2018). The analysis of world trends of territorial branding development. Journal of Social Sciences Research, 5, $306-309$.

Eidelman, B. M., Fakhrutdinova, L. R, \& Bunakov, O. A. (2018). The analysis of content of territorial brands of Kazan and the Republic of Tatarstan. Fournal of Social Sciences Research, 5, 448-453.

Kabirov, I. S. (2016). The Problems of Strategic Planning in Tourist Development Management of the Republic of Tatarstan. Azimuth of Scientific Studies: Economics and Management, 5(2(15)), 102-108.

Kalashnikova, S. V., \& Khanakhok, Z. A. (2015). The Tourism Draw of a Region as One of the Key Factors of its Competitive Position. New Technologies, 1, 3-8.

Neterin, A. V. (2018). Russia's Standing in the International Rating of the Tourism Attractiveness. Bulletin Science and Education, 1(7(43)), 69-71.

Niyaz, K., Gabdrakhmanov, N. K., Rubtzov, V. A., \& Biktimirov, N. M. (2018). Tourist and historical features of settlement on the territory of present tatarstan. Multidisciplinary Social Science \& Management, 2, 211-215. 
Tsurtsilina, A. Y. (2016). The Tourism Appeal as a Factor of Strategic Development of the Regions. Economy and Socium, 10(29), 12-17. 


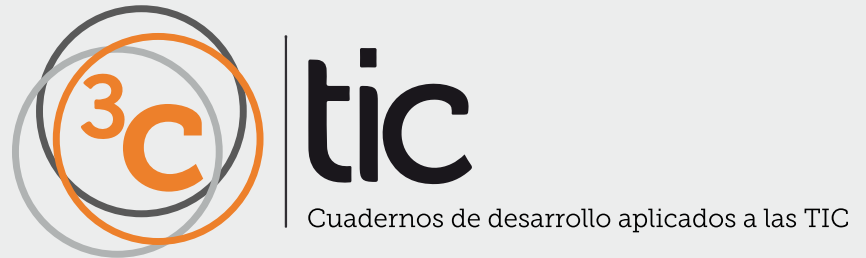

